\title{
ELEVATION EFFECTS ON KEY PROCESSES OF CARBON CYCLING IN SOUTH ECUADORIAN MOUNTAIN FORESTS
}

\author{
Dissertation \\ zur Erlangung des Doktorgrades \\ der Mathematisch-Naturwissenschaftlichen Fakultät \\ der Georg-August-Universität Göttingen
}

vorgelegt von

Gerald Moser

aus Ried i. I.

Göttingen, im Dezember 2007 
D7

Referent: Prof. Dr. Christoph Leuschner

Korreferent: apl. Prof. Dr. Michael Kessler

Tag der mündlichen Prüfung: 24.1.2008 


\section{Table of contents}

Chapter 1

General introduction

Chapter 2

A characterisation of the topography, climate, soils and vegetation of five forest stands along an elevation gradient in South Ecuador

\section{Chapter 3}

Altitudinal changes in stand structure and biomass allocation of tropical mountain forests in relation to microclimate and soil chemistry:

a transect study in Ecuador and a neotropical meta-analysis

G. Moser, M. Röderstein, N. Soethe, D. Hertel, Ch. Leuschner

\section{Chapter 4}

Large altitudinal increase in tree root/shoot ratio in tropical mountain forests of

Ecuador

Ch. Leuschner, G. Moser, C. Bertsch, M. Röderstein, D. Hertel

\section{Chapter 5}

Altitudinal change in LAI and stand leaf biomass in tropical montane forests:

a transect study in Ecuador and a pan-tropical meta-analysis

G. Moser, D. Hertel, Ch. Leuschner

\section{Chapter 6}

Fine and coarse root dynamics of tropical montane forests along an altitudinal transect in South Ecuador

G. Moser, M. Röderstein, S. Graefe, N. Soethe, D. Hertel, Ch. Leuschner

\section{Chapter 7}

Synthesis

Chapter 8

Appendix

Acknowledgements 

Meiner Familie 



\section{1 \\ GENERAL IN TRODUCTION}

\subsection{INTRODUCTION}

Tropical mountain rainforests are exceptional ecosystems due to their function as large carbon pools, their important role in the global water cycle and their high biodiversity. The mayority of studies assessing the carbon pools of tropical rainforests have been conducted in lowlands, thus the understanding of the ecosystem functions of tropical montane forests with respect to carbon, water and nutrient turnover is still limited (Bruijnzeel \& Proctor 1995). Their elementary ecosystem services, for example as important water catchment areas for growing urban centres in the lowlands, and their enormous biodiversity is documented in an increasing number of studies (Gentry 1995, Brehm et al. 2005, Brown \& Kappelle 2001). Nevertheless, only few investigations on the water and nutrient turnover of these ecosystems have been conducted so far (Bruijnzeel \& Proctor 1995).

Little is known about the relevance of these forests for the global carbon cycle and their impact on global warming (Clark 2007). On the one hand, the increasing database on carbon sequestration and turnover in tropical lowland forests indicates a great relevance of these ecosystems for the global carbon budget. Precise data on the importance of tropical montane forests in terms of carbon pools and annual carbon fixation or release are still missing (Soepadmo 1993, Dixon et al. 1994). On the other hand, tropical mountain forests are being destroyed at an alarming rate. For Ecuador, the area reduction of natural rainforests between 1990 and 2000 was $1.5 \%$, between 2000 and 2005 even $1.7 \%$ (FAO 2007). The report on "The state of the worlds forests 2007" states for South America the highest number of critically endangered, endangered and vulnerable tree species as compared to all other continents due to forest conversion (FAO 2007).

According to the estimations of wood biomass in forests of Ecuador (FAO 2005) a conversion rate of $1.7 \%$ equals 27,1 Mio tons of carbon not being stored by the forest per year. The consequences for the regional and global carbon cycle, for the water cycle and the welfare of people due to missing ecosystem services still remain speculative.

Mountain forests in the tropics are of special interest for ecosystem research because of their extension along altitudinal gradients, thus making it possible to study the influence of environmental factor such as temperature and precipitation on important ecosystem functions. With increasing altitude the temperature changes, typically with $6.1 \mathrm{~K} \mathrm{~km}^{-1}$ (Walker \& Flenley 1979). The amount of precipitation at the eastern slopes of the Andes in South Ecuador increases from the lowland to the highest peaks (Bendix et al. 2008). Especially the low temperature at high elevations might influence profound ecosystem functions (Bird et al. 2001). Investigation on carbon fixation and turnover in tropical montane forests can therefore not only reveal critical lacks in the understanding of the role of tropical rainforests in the global carbon cycle, but may also permit deep insights into the effects of global warming on the carbon balance of these ecosystems. 


\subsection{THE DEPENDENCE OF ABOVEGROUND FOREST STRUCTURE ON ELEVATION}

Alexander von Humboldt, travelling from the equatorial lowlands up to the highest peaks of the Ecuadorian Andes, was one of the first natural scientists who observed and documented an altitudinal change in forest structure and species composition (Fig.1.1) This first observation held true for all tropical humid mountains and caused deep fascination and speculation about its ecological reasons (Whitmore 1998). The most outstanding changes with increasing elevation are decreasing tree heights, decreasing leaf areas and a trend to smaller and thicker leaves (Ashton 2003).

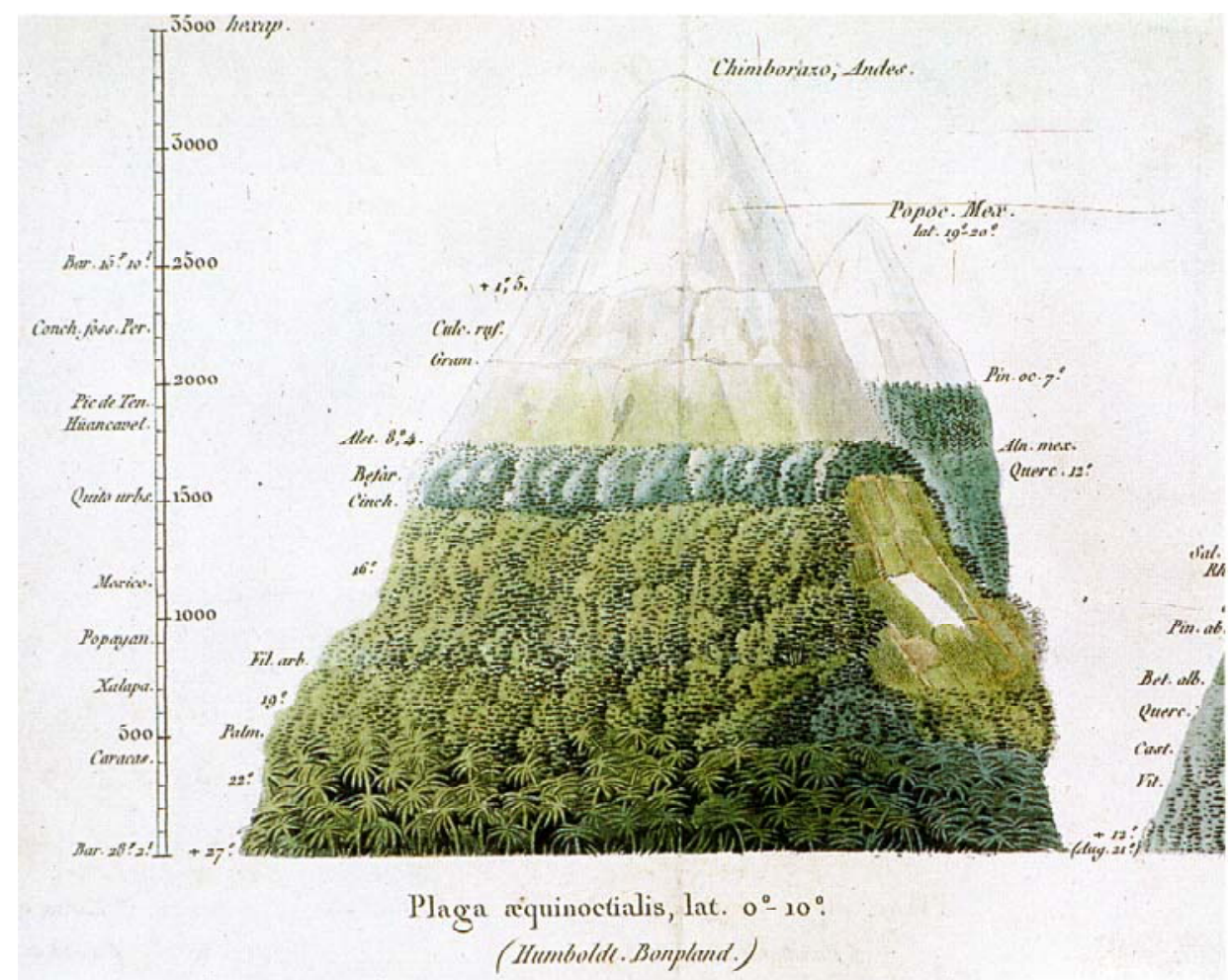

Figure.1.1: Historical view of the altitudinal vegetation zones along the slopes of the volcano Chimborazo in Ecuador (by Alexander von Humboldt and Aimé Bonpland).

A number of hypotheses aim to explain the reasons for these distinctive structural changes from tall to stunting trees with increasing elevation. The growth reduction of forest trees may be caused by (1) periodic drought stress on shallow soils (van Steenis 1972), (2) water saturated soils restricting root respiration (Hetsch \& Hoheisel 1976), (3) reduced leaf temperatures caused by a closed and dense cloude cover (Grubb 1977), (4) strong winds (Sugden 1986), or (5) elevated UV-B radiation and limited rates of photosynthesis (Flenley 1995). Another hypothesis explains tree stunting by a limited nutrient uptake at high elevation, which could be caused (i) by low transpiration rates due to high relative air humidity (Odum 1970), (ii) by high soil acidity (Grubb \& Tanner 1976), or (iii) by limited litter decomposition and mineralization rates (Edwards \& Grubb 1977, Heaney \& Proctor 1989). Most of these hypotheses have not been confirmed with empirical data yet. The underlying causes for vertical vegetation zones in tropical mountains and their consequences for ecosystem processes in different altitudes are still not completely understood (Bruijnzeel \& Proctor 1995, Richards 1996, Whitmore 1998, Hafkenscheid 2000). 


\subsection{DEPENDENCE OF BELOWGROUND CARBON POOLS AND TURNOVER ON ELEVATION}

An particularly huge lack of knowledge exists with regard to the rhizosphere of tropical lowland and montane rainforests. Espeleta \& Clark (2007) complain that in-depth investigations into the belowground allocation across multidimensional gradients within a single ecosystem type are still missing. Since total root production in temperate and boreal forests can reach 30-50\% of total NPP (e.g. Ruess et al. 1996), it may be of similar magnitude in tropical forest ecosystems. On a global scale it was assumed that fine roots contribute about 50\% of NPP in forest ecosystems (Vogt et al. 1996), although they are estimated to account for less than 3\% of terrestrial biomass (Jackson et al 1997). The few published studies on the rhizosphere of mountain rainforests (e.g. Edwards \& Grubb 1977, Cavellier 1992, Vance \& Nadkarni 1992, Priess et al. 1999) indicate, that the carbon pools within the belowground biomass and the soil organic carbon (SOC) in these forests are considerable. Systematic investigations of the total root biomass (coarse and fine roots) of tropical forests in different elevations are still missing, although several studies (Vogt et al. 1996, Cairns et al. 1997, Kitayama \& Aiba 2002) have lead to the assumption that tropical montane forests reach higher profile sums of fine roots (diameter $<2 \mathrm{~mm}$ ) than lowland rainforests.

This assumption has been supported by Röderstein (2006) who studied the structure and dynamics of the fine root system of tropical montane rainforests in different elevations in the Reserva Biologica San Francisco (RBSF) and the adjacent National Park Podocarpus: she investigated the standing crop of fine roots in three forest stands at 1890, 2380 and 3060 $m$ a.s.l. and found it to increase with elevation by a factor 1.7 .

Understanding of the influence of elevation on soil organic matter (SOM) is much better than of its effect on root biomass. In comparison to lowland rainforests the SOM pools in mountain rainforests are considerably higher, because of the increasing carbon content with decreasing temperatures and increasing soil humidity (Bird et al. 1994). More recent investigations have shown not only an increase of SOM (Trumbore et al. 1996) but also a decrease of SOM turnover and microbial respiration with increasing elevation (Raich \& Schlesinger 1992). In addition, an increasing concentration of SOM within the topsoil was found (Zinke et al. 1986). The thickness of the organic layer $\left(\mathrm{O}_{l}, \mathrm{O}_{\mathrm{f}}\right.$ and $\mathrm{O}_{\mathrm{h}}$ horizons) increases with altitude, indicating a slowdown of litter decomposition (Schrumpf et al. 2001, Röderstein 2005).

\subsection{PRODUCTIVITY OF TROPICAL MONTANE RAINFORESTS}

Knowledge about the aboveground biomass of montane rainforests is not yet satisfying, either, as most silvicultural assessments of wood biomass or volume have been focused on economically relevant stands or tree species. Nevertheless, the amounts of carbon in the aboveground biomass of these forests are much better known than those stored in the root system (Whitmore 1998). Clark et al. (2001) have listed 39 studies on the productivity of tropical rainforests, most of them from the lowlands, always including only a few components of net primary production (NPP). In none of these studies fine or coarse root production had been considered. The reported amounts for NPP ranging from 1.7 to 21.7 $\mathrm{Mg}$ dry mass $\mathrm{ha}^{-1} \mathrm{yr}^{-1}$ can not be transfered to tropical montane forests. On the other hand, Espeleta \& Clark (2007) complain that publications on root studies of tropical forests do not include data on aboveground biomass or production, thus making it impossible to determine the relative changes in biomass allocation with increasing elevation. 


\subsection{OBJECTIVES AND HYPOTHESES}

This study on forests in South Ecuador aims at filling some of the great gaps of knowledge on the carbon cycling in mountain rainforests at elevations between 1000 and $3000 \mathrm{~m}$. Special attention has been payed to the as yet unknown carbon turnover by fine root production, to stem diameter increment and litter production, and to the changes of these parameters with increasing elevation.

The following parameters have been investigated along an altitudinal transect to assess their response to increasing elevation:

i) leaf area index (LAI), specific leaf area (SLA), leaf standing crops and leaf production

ii) stem wood production

iii) fine, coarse and large root biomass and annual biomass production

iv) total above- and belowground NPP

v) root-shoot ratio of biomass and productivity

vi) annual fluxes of carbon within the above- and belowground litter production and their relation to rates of decomposition

The determination of carbon fixation by plant net primary production (NPP) in mountain rainforests at different elevations along a $2000 \mathrm{~m}$ long altitudinal transect is of overriding importance. This approach incorporates two crucial new aspects which have not yet been considered (Clark et al. 2001):

i) Several methods were used to estimate not only aboveground biomass production, but carbon turnover by fine, coarse and large root production as well, thus allowing for the assessment of absolute amounts of above- and belowground NPP in tropical rainforests. This approach revealed the importance of total root production for the ecosystem's carbon balance.

ii) For the very first time the sum of above- and beloground NPP of five forest stands along an extended gradient from the lower montane altitudinal belt (1000 $\mathrm{m}$ a.s.1.) up to an tree line near elfin forest (3000 m a.s.1.) was comparatively investigated, thereby revealing new insights into the temperature dependence of key processes within the ecosystem carbon cycle.

The results of these investigations are essential to assess carbon allocation patterns and to understand the relationship between above- and belowground plant production in tropical rainforests. They also illuminate the influence that changes of temperature have on NPP and carbon allocation in tropical mountain forests. Furthermore, the results of this gradient study offer an explaination for the noticeable decline of tree height from the lowlands up to the alpine tree line.

Four hypotheses have been tested:

i) Since total leaf areas are comparatively large even at high altitudes and limitation of photosynthesis by low temperatures is negligible, the decrease of total above- and belowground NPP along a $2000 \mathrm{~m}$ altitudinal gradient of tropical montane rainforest is small.

ii) Decreasing tree height and aboveground productivity with increasing altitude are caused mainly by changes in carbon allocation, only secondarily by limitations of photosynthesis (sink oriented hypothesis, Körner 1999). Mountain forest trees close to the alpine tree line consume a higher portion of NPP for the production of fine roots than trees in lower montane forests. 
iii) Not only the relative portion of fine root production on total NPP increases with increasing elevation, but the absolute amount of fine root production and the total living fine root biomass as well.

iv) The main reason for the observed changes in carbon allocation pattern and the increase in fine root biomass and turnover is nutrient limitation caused by reduced biological activity in soils at high elevations. The low biological activity as a result of low temperature and high soil humidity reduces the nutrient availability for plants living close to the timberline. The elevation dependent change of allocation patterns is therefore a response to the changing resource limitation of plant growth along the altitudinal gradient, ranging from a predominant light limitation in the lower montane belt to a predominant nutrient limitation at high elevations.

During a 16 months fieldwork period in South Ecuador the above- and belowground biomass allocation pattern of five stands between 1000 and $3000 \mathrm{~m}$ a.s.l. were investigated. The following processes within the carbon cycle covering the most important above- and belowground compartments were studied:

i) annual leaf biomass production,

ii) annual production of flowers, fruits and fine litter,

iii) annual stem diameter increment and estimation of wood production,

iv) annual fine root production,

v) annual coarse and large root diameter increment to estimate productivity.

This study was part of the DFG funded Research Unit 402 "Functionality in a Tropical Mountain Rainforest: Diversity, Dynamic Processes and Utilization Potentials under Ecosystem Perspectives“ (www.bergregenwald.de). It cooperated with two studies conducted in the same DFG project by M. Röderstein (2006) and N. Soethe (2006) both focussing on the fine and coarse root systems of three forest stands ranging from 1900 to $3000 \mathrm{~m}$ a.s.1. The data collected in these studies have been included into the calculations of belowground NPP in the extended altitudinal transect. Furthermore, a close collaboration with a pedological study at the TU Dresden, conducted by S. Iost (2007) gave important additional information on the changes of soil nutrient status and respiratory activity with increasing elevation. Further insights into tree physiology and fine root dynamics were available from two studies being conducted along the Ecuadorian altitudinal transect by A. Zach (unpubl.) and S. Graefe (unpubl.). Additional source of data were the diplom theses about the structure, morphology, the nutrient status and hydraulic conductivity of roots, twigs and leaves conducted by C. Bertsch, M. Unger and B. Schuldt.

\subsection{REFERENCES}

Ashton, P.S. 2003. Floristic zonation of tree communities on wet tropical mountains revisited. Perspectives in Plant Ecology Evolution and Systematics 6: 87-104.

Bird, M.I., Santruckova, H., Lloyd, J. \& Veenendaal, E. 2001. Global soil organic carbon pool. In: Schulze, E.-D. et al. (eds.). Global biogeochemical cycles in the climate system. Academic Press, 185-199.

Bird, M.I. Haberle, S.G., Chivas, A.R. 1994. Effect of altitude on the carbon-isotope composition of forest and grassland soils from Papua-New-Guinea. Global Biogeochemical Cycles 8: 13-22.

Bruijnzeel, L.A., Proctor, J. 1995. Hydrology and biogeochemistry of tropical montane cloud forest: What do we really know? In: Hamilton, L.S., Juvik, J.O. \& Scatena, F.N. 
(eds.). Tropical montane cloud forests. Springer, New York. Ecological Studies 110, pp. 38-78.

Brown, A.D., Kappelle, M. 2001. Introduccion a los bosques nublados del Neotropico: Una sintesis regional. In: Kappelle, M., Brown, A.D. (eds.). Bosques Nublados del Neotropico. INBIO, Santo Domingo de Heredia, Costa Rica. Pp. 25-40.

Brehm, G., Pitkin, L.M., Hilt, N., Fiedler, K. (2005): Montane Andean rain forests are a global diversity hotspot of geometrid moths. Journal of Biogeography 32: 1621-1627.

Cairns, M.A., Brown, S., Helmer, E.H., Baumgardner, G.A. 1997. Root biomass allocation in the world's upland forests. Oecologia 111: 1-11.

Cavellier, J. 1992. Fine-root biomass and soil properties in a semideciduous and a lower montane rain forest in Panama. Plant and Soil 142: 187-201.

Clark, D.A. 2007. Detecting tropical forests' responses to global climatic and atmospheric change: current challenges and a way forward. Biotropica 39: 4-19.

Clark, D.A., Brown, S., Kicklighter, D.W., Chambers, J.Q., Thomlinson, J.R., Ni, J., Holland, E.A. 2001. Net primary production in tropical forests: An evaluation and synthesis of existing field data. Ecological Applications 11: 371-384.

Dixon, R.K., Brown, S., Houghton, R.A., Solomon, A.M., Trexler, M.C., Wisniewski, J. 1994. Carbon pools and flux of global forest ecosystems. Science 263: 185-190.

Edwards, P.J. \& Grubb, P.J. 1977. Studies of mineral cycling in a montane rainforest in New Guinea. I. The distribution of organic matter in the vegetation and soil. Journal of Ecology 65: 943-969.

Espeleta, K-F-. Clark, D.A. 2007. Multi-scale variation in fine-root biomass in a tropical rain forest: a seven year study. Ecological Monographs 77: 377-404.

FAO 2005. State of the Word's Forests. Rom.

FAO 2007. State of the Word's Forests. Rom.

Flenley, J.R. 1995. Cloud forest, the Massenerhebung Effect, and ultraviolet insolation. In: Hamilton, L.S., Juvik, J.O., Scatena, F.N. (eds.). Tropical montane cloud forests. Springer, New York. Ecological Studies 110: 150-155.

Gentry, A. H. 1995. Patterns of diversity and floristic composition in neotropical montane forests. In: Churchill, S.P. et al. (eds.). Biodiversity and conservation of neotropical montane forests. The Bronx, New York Botanical Garden, pp. 103-126.

Grubb, P.J. 1977. Control of forest growth and distribution on wet tropical mountains: with special reference to mineral nutrition. Annual Review of Ecology and Systematics. 8: 83-107.

Grubb, P.J. Tanner, E.V.J. 1976. The montane forests and soils of Jamaica: a reassessment. Journal of the Arnold Arboretum 57: 33-68.

Hafkenscheid,R.L.L.J., 2000. Hydrology and biogeochemistry of tropical montane rain forests of contrasting stature in the Blue Mountains, Jamaica. Dissertation Universiteit Amsterdam, Print Partners Ipskamp, Enschede, The Netherlands.

Heaney, A., Proctor, J. 1989. Chemical elements in litter in forests on Volcan Barva, Costa Rica. In: Proctor, J. (ed). Mineral nutrients in tropical forest and savanna ecosystems. Blackwell Scient. Press, Oxford. pp. 255-271.

Hetsch, W., Hoheisel, K. 1976. Standorts- und Vegetationsgliederung in einem tropischen Nebelwald. Allgemeine Forst- u. Jagdzeitung. 147: 200-209.

Iost, S. 2007. Soil respiration, microbial respiration and mineralisation in soils of montane rainforests of Southern Ecuador: influence of altitude. Dissertation TU Dresden, pp. 171.

Jackson, R.G., Mooney,H.A., Schulze, E.D. 1999. A global budget of fine root biomass, surface area, and nutrient concentrations. Proceedings of the National Academy of Sciences (USA) 94: 7362-7366. 
Kitayama, K., Aiba, S.-I. 2002. Ecosystem structure and productivity of tropical rain forests along altitudinal gradients with contrasting soil phosphorus pools on Mount Kinabalu, Borneo. Journal of Ecology 90: 35-51.

Körner, Ch. 1999. Alpine Plant Life. Springer, Berlin.

Litherland, M., Aspden, J., Jemielita, R. 1994. The metamorphic belts of Ecuador. No. 11 in Overseas Memoir of the British Geological Survey, Keyworth, U.K.

Odum, H.T. 1970. Rain forest structure and mineral cycling homeostasis. In: Odum, H.T., Pidgeon, R.F. (eds.). A tropical rain forest. US Atomic Energy Commission, Oak Ridge. Pp. H3-52.

Priess, T., Then, C., Fölster, H. 1999. Litter and fine root production in three types of tropical premontane rain forest in Venezuela. Plant Ecology 143: 171-187.

Raich, J.W., Schlesinger, W.H. 1992. The global carbon dioxide flux in soil respiration and its relationship to vegetation and climate. Tellus 44B: 81-99.

Richards, P.W. 1996. The tropical rain forest. 2nd ed. Cambridge Univ. Press, Cambridge.

Röderstein, M., Hertel, D., Leuschner, Ch. 2005. Above- and belowground litter production in three tropical montane forests in southern Ecuador. Journal of Tropical Ecology 21: 483-492.

Röderstein, M. 2006. Struktur und Dynamik des Feinwurzelsystems von tropischen Bergwäldern in Abhängigkeit von der Meereshöhe in Südecuador. Dissertation University Göttingen. Forschungszentrum Waldökosysteme, Reihe A, Bd. 197.

Ruess, R.W., van Cleve, K., Yarie, J., Viereck, L.A. 1996. Contributions of fine root production and turnover to the carbon and nitrogen cycling in taiga forests of the Alaskan interior. Canadian Journal of Forest Research. 26: 1326-1336.

Schrumpf, M., Guggenberger, G., Valarezo, C. \& Zech, W. 2001. Tropical montane rain forest soils. Development and nutrient status along an altitudinal gradient in the South Ecuadorian Andes. Die Erde 132: 43-59.

Soepadmo, E. 1993. Tropical rain forests as carbon sinks. Chemosphere 27: 1025-1039.

Soethe, N. 2006. Structure and function of root systems at different altitudes of a south Ecuadorian montane forest. Dissertation Humboldt-University Berlin, pp. 139.

Sugden, A.M. 1986. The montane vegetation and flora of Margarita Island, Venezuela. J. Arnold Arboretum 67: 187-232.

Trumbore, S.E., Chadwick, O.A., Amundson, R. 1996. Rapid exchange between soil carbon and atmospheric carbon dioxide driven by temperature change. Nature 272: 393-396.

Vance, E.D., Nadkarni, N.M. 1992. Root biomass distribution in a moist tropical montane forest. Plant and Soil 142: 31-39.

van Steenis, C.G.G.J. 1972. The Mountain Flora of Java. E.J. Brill, Leiden.

Vogt, K.A., Vogt, D.J., Palmiotto, P.A., Boon, P., O'Hara, J., Asbjornson, H. 1996. Review of root dynamics in forest ecosystems grouped by climate, climatic forest type and species. Plant and Soil 187: 159-219.

Walker, D., Flenley, J.R. 1979. Late quaternary vegetational history of the Enga district of upland Papua New Guinea. Philosophical Transaction of the Royal Society London, Series B, 286: 265-344.

Whitmore, T.C. 1998. An introduction to tropical rain forests. Oxford Univ. Press, 2nd ed.

Zinke, P.J., Strangenberger, A.G., Post, W.M., Emanuel, W.R., Olson, J.S. 1986. Worldwide organic soil carbon and nitrogen data. NDP-018, Carbon Dioxide $\begin{array}{llllll}\text { Information Centre, Oak Ridge National Laboratory. } & 136 & \text { p. }\end{array}$ 



\section{A CHARACTERISATION OF THE TOPOGRAPHY, CLIMATE, SOIL AND VEGETATION OF FIVE FOREST STANDS ALONG AN ELEVATION GRADIENT IN SOUTH ECUADOR}

\subsection{TOPOGRAPHY OF THE STUDY AREA}

The investigation along the altitudinal gradient of tropical montane rainforests was conducted in South Ecuador, where the DFG funded Research Unit 402 already had work experience and closely cooperated with the Estación Científica San Franciso (ECSF) and its protected Reserva Biologica San Francisco (RBSF). This collaboration provided both an already existing infrastructure at the research station and scientific cooperation with the Fundación Científica San Francisco.

Three forest plots (sites \#3-5), situaded at 1980 and $2340 \mathrm{~m}$ a.s.l. in the RBSF, and at 3060 $\mathrm{m}$ a.s.1. in the Cajanuma sector of the adjacent National Park Podocarpus (see Fig. 2.1, and Fig.5.1), had already been installed in 2001 by M. Röderstein and N. Soethe, and were now used for new investigations on total biomass pools and NPP portions. Two new plots were installed in 2003 in the National Park sector Bombuscaro, at 1050 and $1540 \mathrm{~m}$ a.s.l. (site $\# 1-2)$ to extend the existing elevation gradient.

The Podocarpus National Park is located in the provinces Loja and Zamora-Chinchipe and covers an area of $1460 \mathrm{~km}^{2}$ (Calderón 2002). Together with the RBSF (ca. $1000 \mathrm{ha}$ ) the National Park protects a typical closed forest area ranging from 900 to $3400 \mathrm{~m}$ a.s.l., and paramos up to $3700 \mathrm{~m}$ a.s.l. The Podocarpus National Park expands to the western and eastern side of the Cordillera Real, the eastern chain of the Andes in South Ecuador. The RBSF is located on the northern slope of the Cerro del Consuelo, which is a foothill of the Cordillera Real. The landscape is characterized by its steep slopes and small ridges, causing a high frequency of natural landslides in the otherwise undisturbed forests.

Table 2.1: Geographic coordinates, elevation, inclination and annual precipitation of the five study plots in South Ecuador.

\begin{tabular}{|c|c|c|c|c|c|}
\hline Plot & 1 & 2 & 3 & 4 & 5 \\
\hline \multirow[t]{2}{*}{ Coordinates } & S $04^{\circ} 06^{\prime} 54^{\prime \prime}$ & S $04^{\circ} 06^{\prime} 42^{\prime \prime}$ & S $03^{\circ} 58^{\prime} 345^{\prime \prime}$ & S $03^{\circ} 59^{\prime} 19^{\prime \prime}$ & S $04^{\circ} 06^{\prime} 71^{\prime \prime}$ \\
\hline & W 78 $58^{\prime} 02^{\prime \prime}$ & W 7858'20"' & W 7904'64" & W 7904'55" & W $79^{\circ} 10^{\prime} 58^{\prime \prime}$ \\
\hline Elevation ( $m$ a.s.I.) & 1050 & 1540 & 1890 & 2380 & 3060 \\
\hline Inclination $\left(^{\circ}\right)$ & 26 & 10 & 31 & 28 & 27 \\
\hline Rainfall $^{\mathrm{a}}(\mathrm{mm})$ & c. 2230 & c. 2300 & c. 1950 & c. 5000 & c. 4500 \\
\hline
\end{tabular}

${ }^{a}$ Extrapolated rainfall amounts from own measurements at $1050 \mathrm{~m}$ and rain gauges from P. Emck and M. Richter (unpubl.), University of Erlangen, at 1950, 2680 and $3170 \mathrm{~m}$. 
The whole studied elevation gradient is located at the eastern slopes of the South Ecuadorian Andes with a maximum distance of $30 \mathrm{~km}$ between the plots. All study sites are located on moderately steep slopes between $26-30^{\circ}$, apart from site \#2 $\left(10^{\circ}\right)$, facing northeast to north-west (Tab.2.1). The five study sites are located in representative forest stands of the respective altitudinal vegetation belts in this region. The forest site $\# 5$ is situated close to the upper tree line, which runs in the South Ecuadorian Andes at an exceptional low elevation, between 3200 and $3400 \mathrm{~m}$ a.s.1. (see Chap.2.4). The investigated study plots (each $400 \mathrm{~m}^{2}$ ) were established in more or less homogenous parts of the forest with closed canopies and a representative frequency of emergent trees on the lowest site.

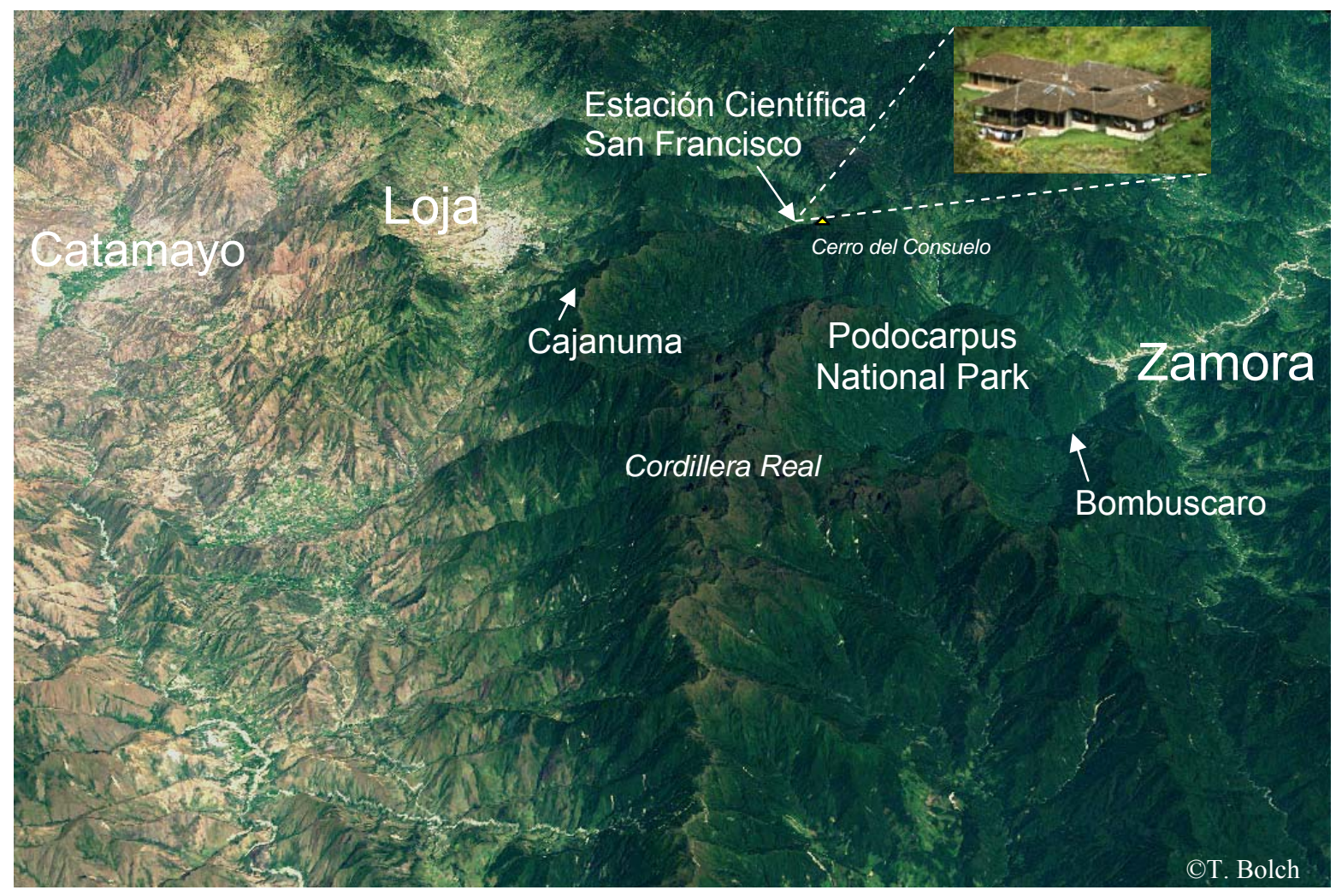

Figure 2.1: 3D-image of the study regions showing the $2000 \mathrm{~m}$ elevation gradient at the eastern slopes of the South Ecuadorian Andes from Bombuscaro to Cajanuma (arrows indicate location of study plots) and the vegetation change from humid rainforests at the eastern slopes of the Cordillera Real to the dry dornbush in the inter Andean valley around Catamayo.

\subsection{Climate}

\subsubsection{CLIMATIC CONDITIONS IN THE STUDY AREA}

The course of the inner tropical convergence zone in Ecuador is conspicuously modified by regional conditions such as the topography of the Andean mountain system. The Cordillera Real forms the South Ecuadorian meteorological divide between the moist Amazonian basin in the east and the dry inter Andean valley in the west (see Fig.2.2). In the study area at the eastern slopes of the Cordillera Real the prevailing easterly flow causes a strong orographic ascent of warm and moist air originating from the Amazonian lowlands. This causes increasing cloudiness and frequent and heavy rainfall and fog water input (Bendix et al. 2008) during 11-12 humid months per year (Beck et al. 2008). Annual mean precipitation at the foot of the Cordillera Real in Zamora (960 m a.s.1.), $8 \mathrm{~km}$ from the 
lowest study sites is close to $2000 \mathrm{~mm}$ and increases with elevation to more than $4000 \mathrm{~mm}$ $\mathrm{yr}^{-1}$ at $2930 \mathrm{~m}$ a.s.1. at Cerro del Consuelo. Precipitation as high as $7786 \mathrm{~mm} \mathrm{yr}^{-1}$ have been documented for the highest top of the Cerro del Consuelo (Las Antenas) at $3185 \mathrm{~m}$ a.s.l. (Fabian et al. 2005). These authors reported an increase of fog water fraction in total water input between 1800 and $3185 \mathrm{~m}$ a.s.l. from $5 \%$ to $30 \%$ (55 to $2747 \mathrm{~mm} \mathrm{yr}^{-1}$, respectively). The extrapolated rainfall amounts from own measurements at $1050 \mathrm{~m}$ and rain gauges from P. Emck and M. Richter (unpubl.), University of Erlangen at 1950, 2680 and $3170 \mathrm{~m}$ for the five study plots also show an increasing tendency with increasing altitude (Tab.2.1).

In most years a westerly flow during some weeks between November and January causes heavy convective rainfall at the western slope of the Cordillera, resulting in a drier period in the study area at the eastern slopes (Bendix \& Lauer 1992).

The climatic elevation gradient along the slopes of the RBSF or between Zamora and Loja is well documented (e.g. Bendix et al. 2008, Richter 2003). When considering hourly sums of precipitation, rather uniform precipitation frequencies and volumes can be observed at $1960 \mathrm{~m}$ a.s.1. close to the ECSF (see Fig.2.3). This uniformity changes to an expressed seasonality with a peak of precipitation between May and August with increasing altitude up to the Cerro del Consuelo at $3180 \mathrm{~m}$ a.s.l. A similar pattern was found regarding the hourly means of wind velocities (Fig.2.4), with rather low and uniform velocities being recorded at the ECSF and at higher elevations within the RBSF (TS1), while much higher wind velocities and a pronounced seasonality were recorded at the mountain tops.
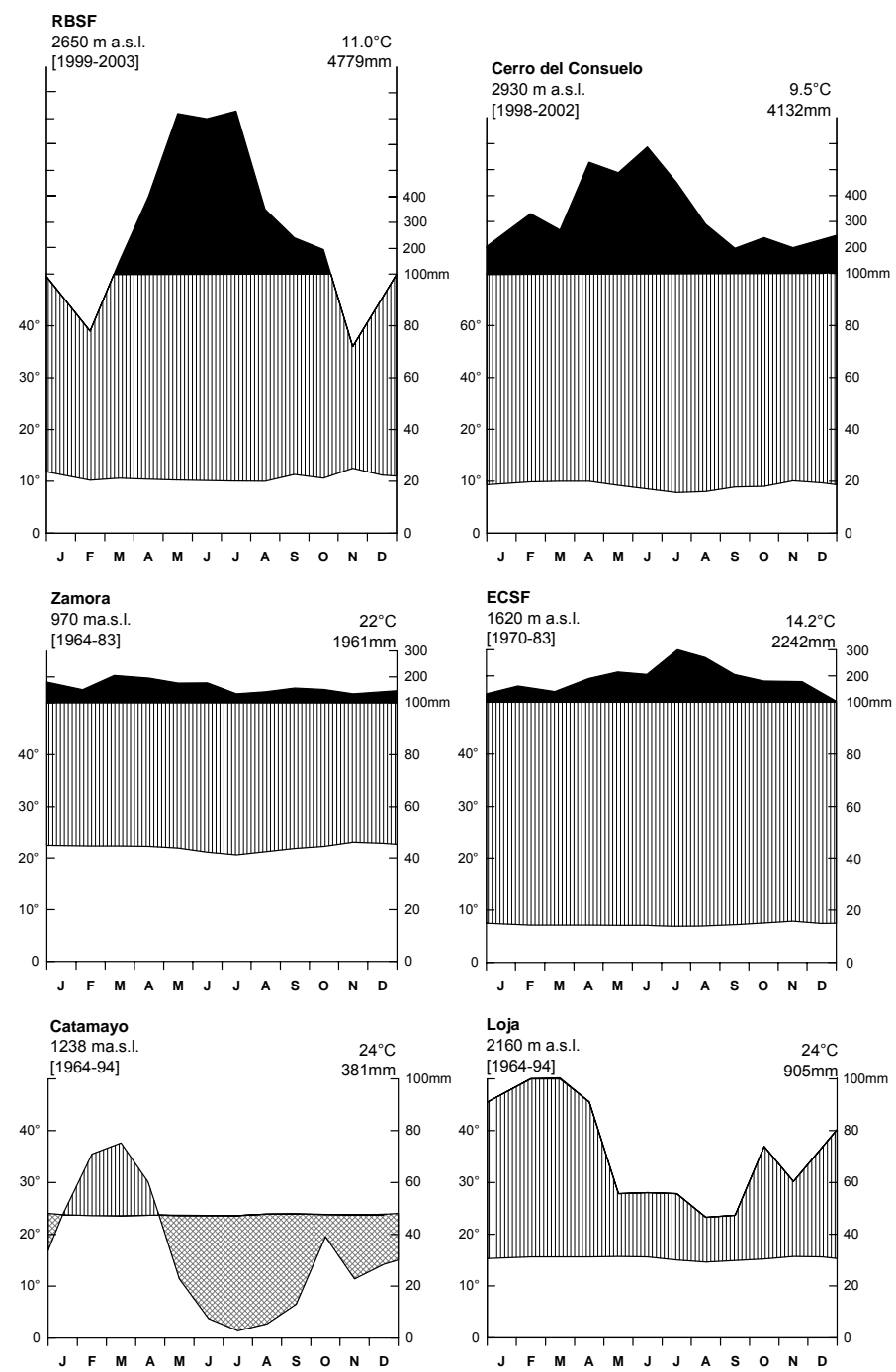

Figure 2.2: Climate diagrams from the study area to the dry inter andine valleys at Catamayo, documenting the precipitation gradient between $970 \mathrm{~m}$ a.s.l. in Zamora, $1620 \mathrm{~m}$ a.s.l. close to ECSF, $2650 \mathrm{~m}$ a.s.1. at RBSF, and 2930 $\mathrm{m}$ a.s.l. at Cerro del Consuelo; data for RBSF and Cerro del Consuelo from Bendix et al. (2006), data for ECSF from Walter \& Breckle (2004), data for Catamayo, Loja and Zamora from Maldonado (2002). 
Since frequency of precipitation and cloudiness increase with elevation, solar irradiance decreases (Fig.2.5). A seasonality of solar irradiance is visible at all three considered elevations, reflecting the pattern of the prevailing easterly winds from February to October, and a period with a higher frequency of westerly winds between November and January, which also affects the precipitation pattern. In a measuring campaign between March and May 2004 along the studied elevation gradient Unger (2005) could not detect a significant gradient in global irradiance between 1000 and $3100 \mathrm{~m}$ a.s.l. Highest means of daily sums were recorded between 1900 and 2400 m a.s.l., significantly lower values between 1000 and $1500 \mathrm{~m}$ a.s.l. The UV-B radiation showed a weak altitudinal increase.

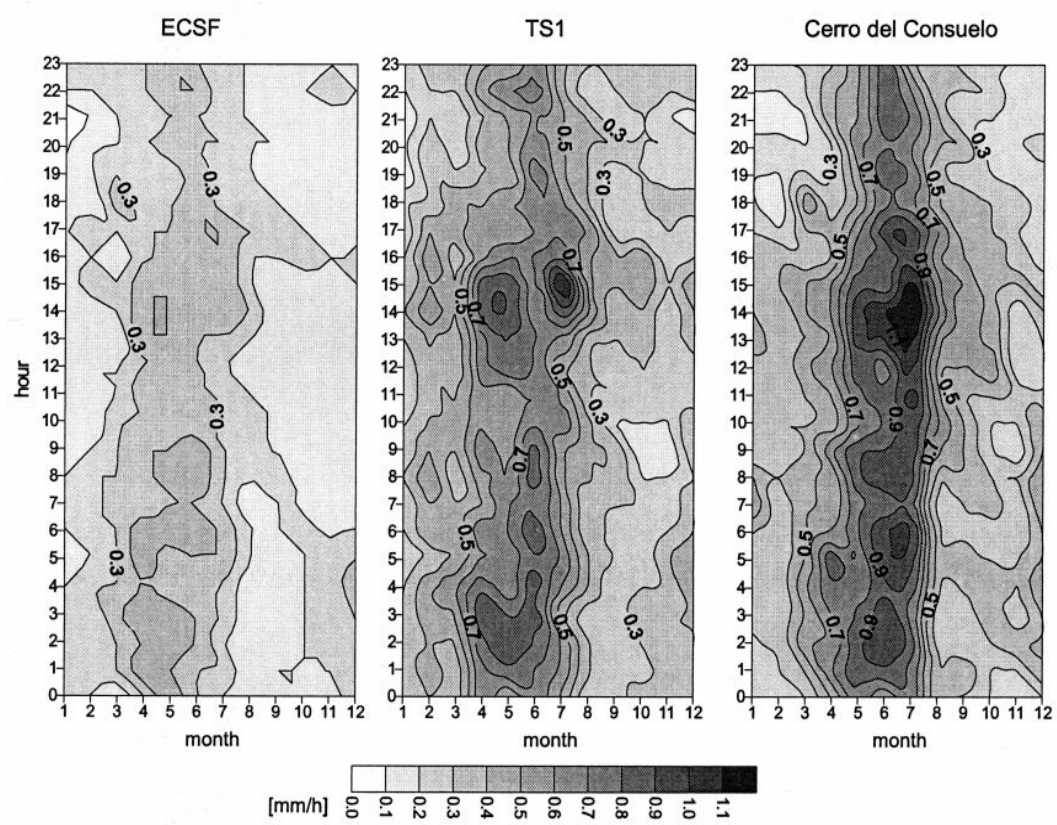

Figure 2.3: Precipitation measured close to the ECSF at $1960 \mathrm{~m}$, in the RBSF (TS1) at $2660 \mathrm{~m}$ and at Cerro del Consuelo at $3180 \mathrm{~m}$ a.s.l. (from Bendix et al. 2008). Hourly means of rainfall for each month are shown.

\subsubsection{MICROCLIMATE OF STUDY SITES}

Microclimatic measurements in the five studied forest stands were conducted from April 2003 onwards (continued until 2007). In all five plots air temperature and relative air humidity were measured in $1.5 \mathrm{~m}$ height above ground with a Hygroclip S temperature and humidity sensor (Rotronic AG, Swiss). While $1.5 \mathrm{~m}$ above the forest flour meant understorey conditions in the closed forest at $1050 \mathrm{~m}$ elevation, it represented nearly canopy conditions in the studied elfin forest at $3060 \mathrm{~m}$ a.s.l. Data were logged once per hour with a Campbell logger CR 10X (Campbell Scientific, Inc., Logan, UT).

The results display similar patterns for air temperature, relative humidity and the resulting vapour pressure deficit (VPD) as observed for precipitation, wind velocities and solar irradiance at the RBSF. A decreasing trend of air temperatures from site \#1 to \#5 with warmest conditions in November 2003 and January 2004, when westerly winds were prevailing, was observed (see Appendix, Fig.8.1). Annual mean temperatures decreased from 19.4 to $9.4^{\circ} \mathrm{C}$, implying an temperature lapse rate of $0.5 \mathrm{~K}$ per $100 \mathrm{~m}$ altitude inside the forest stands, which is $0.09 \mathrm{~K}$ per $100 \mathrm{~m}$ altitude less than recorded for open field stations (Richter 2003). This is presumably due to stronger shading effects at lower elevations. Maximal annual temperature ranges were 11.5 to $30.2^{\circ} \mathrm{C}$ inside the forest at 
$1050 \mathrm{~m}$ and 3.1 to $18.8^{\circ} \mathrm{C}$ at $3060 \mathrm{~m}$ a.s.1. (Tab.2.2). Temperature never fell below $0^{\circ} \mathrm{C}$ at any of the studied sites.

Relative air humidity inside the forests was very high ( $\sim 90 \%)$ and consistent during the study year at the uppermost forest sites, decreasing only when easterly winds occurred (see Appendix, Fig.8.2). At the lowermost study sites air humidity was also high but showed greater intraday fluctuations throughout the year. Only at site \#1 and \#3 absolute minima of relative air humidity of $15 \%$ were recorded (Tab.2.2). At all other plots minima were above $30 \%$. The resulting pattern for VPD reflects air humidity, with very consistent but low loads at high elevations only interrupted by few weeks with less cloudiness. (see Appendix, Fig.8.3). Conspiciously, VPD stays below $2 \mathrm{hPa}$ during the course of the day for long periods of the year, thus making it impossible for the trees to reach noteworthy rates of transpiration. Absolute maximum of VPD measured at $3060 \mathrm{~m}$ elevation was $14.5 \mathrm{hPa}$ on a cloudless day in January 2004 (Tab.2.2). VPD loads in the understorey of the lowermost three forest stands were in average above $2 \mathrm{hPa}$, reaching $32 \mathrm{hPa}$ on site \#1 and \#3.

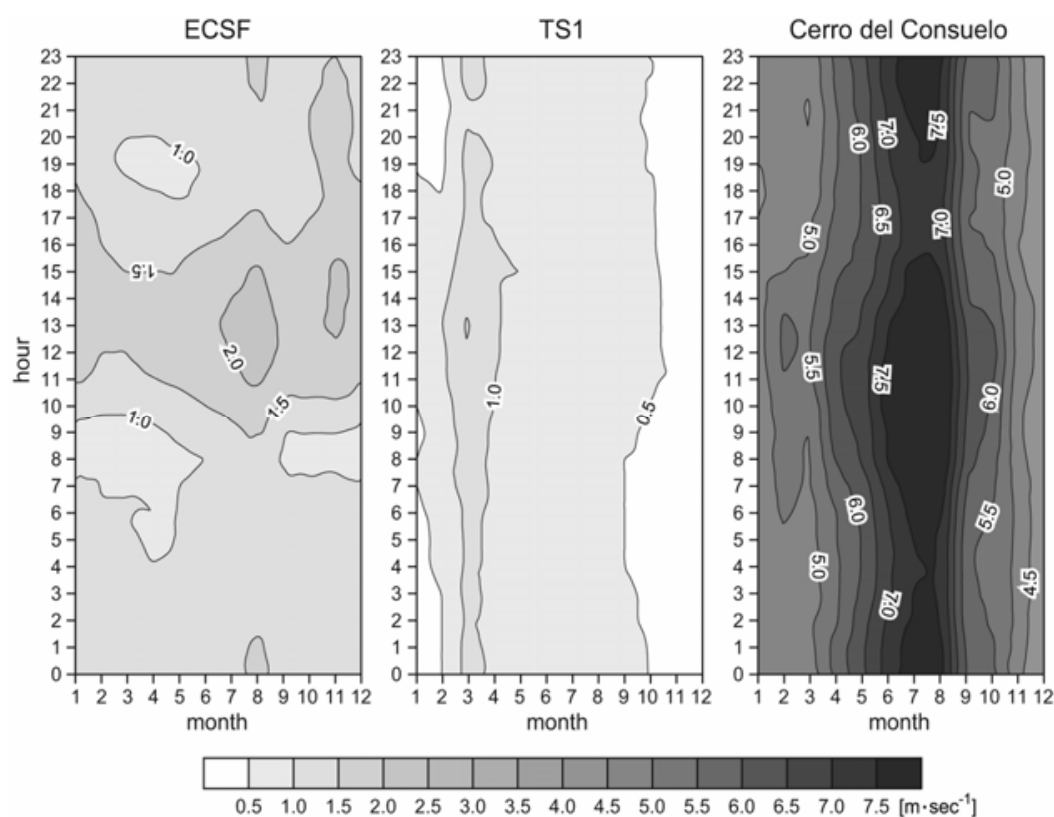

Figure 2.4: Wind velocity measured close to the ECSF at $1960 \mathrm{~m}$, within the RBSF (TS1) at 2660 $\mathrm{m}$ and at Cerro del Consuelo at $3180 \mathrm{~m}$ a.s.l. (from Bendix et al. 2008). Hourly means of wind velocities for each month are shown.
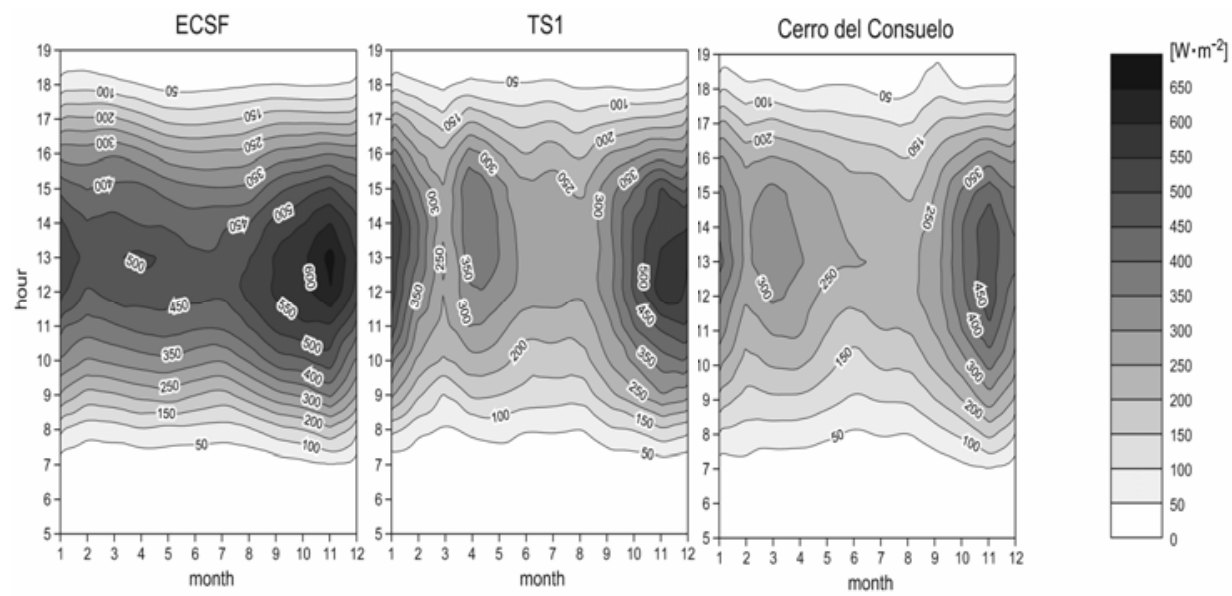

Figure 2.5: Solar irradiance measured close to the ECSF at $1960 \mathrm{~m}$, within the RBSF (TS1) at 2660 $\mathrm{m}$ and at Cerro del Consuelo at $3180 \mathrm{~m}$ a.s.l. (from Bendix et al. 2008). Hourly means of solar irradiance energy for each month are shown. 


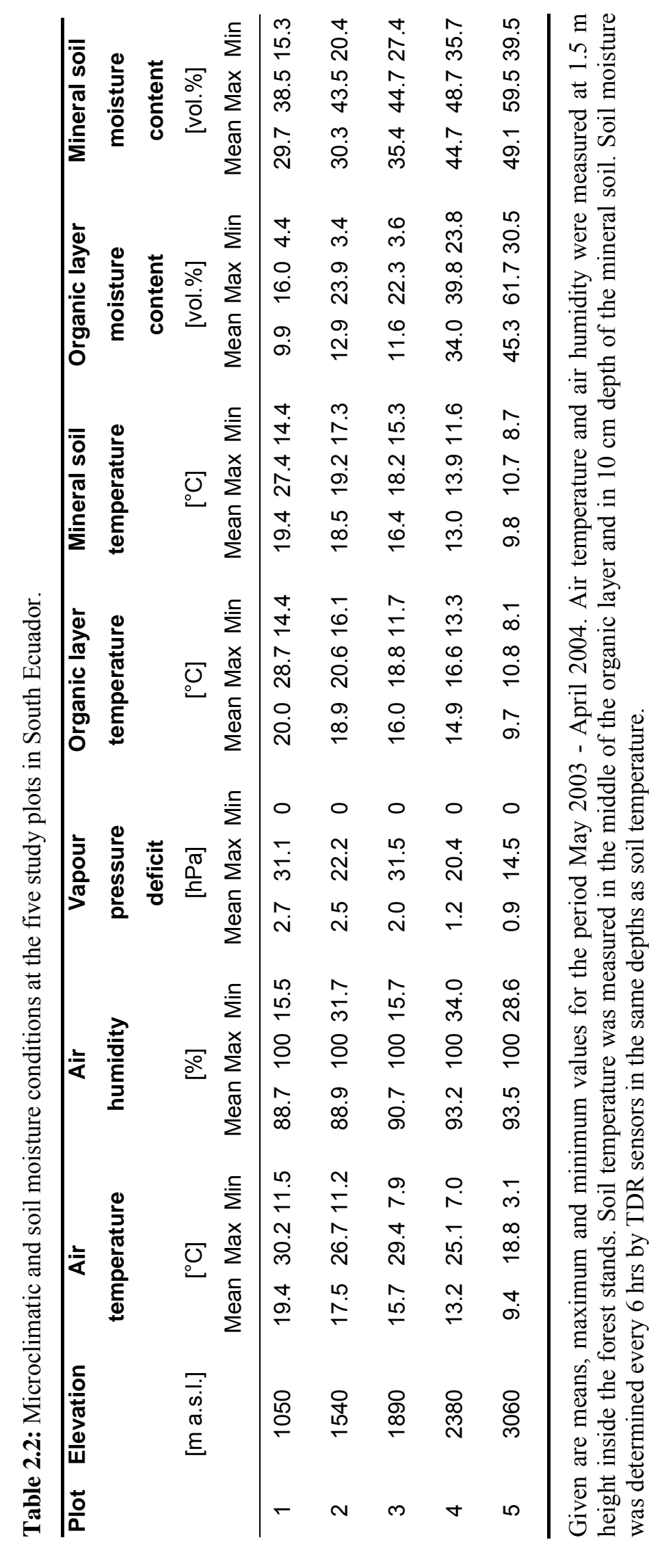




\subsection{GEOLOGY AND SOILS OF THE STUDY AREA}

High ridges, steep slopes and deeply dissected valleys shape the geomorphology of the study area. The frequency of natural landslides is high and for the RBSF a portion of 3.7\% of the area are covered by them (Beck \& Müller-Hohenstein 2001). The upper part of the Cordillera Real, including the uppermost three study sites, is located at a palaeozoic metamorphic belt, called the Chiguinda unit (Fig. 2.6, Litherland et al. 1994). It consists

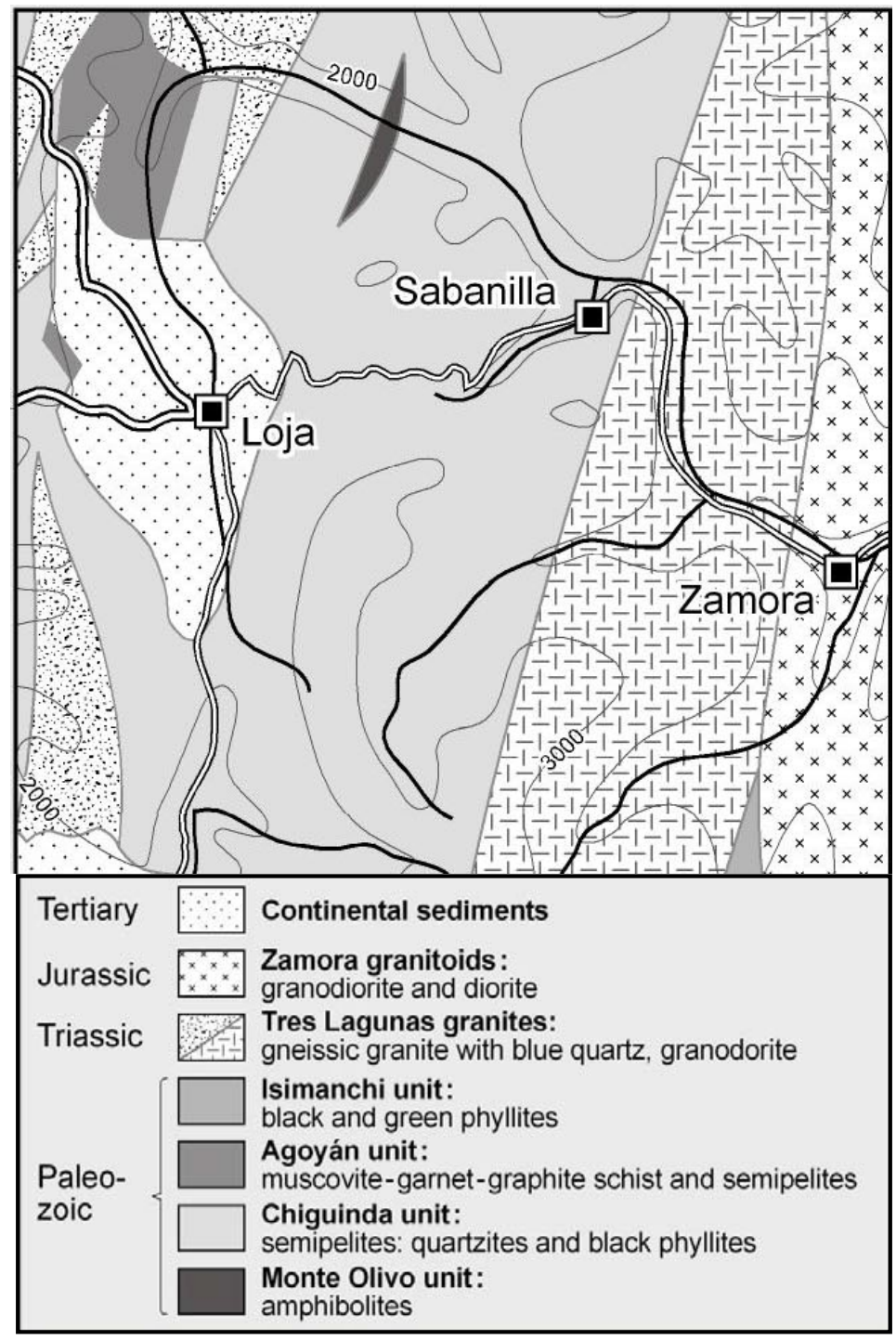
mainly of quartzite and black phyllites, as well as metasiltstones, metasandstones and slates forming a small-scale mosaic of different bedrock. The lower part of the Podocarpus National Park, including the Bombuscaro sector, is located in the Zamora batholith unit, which consists of leuco-granodiorites and hornblende granodiorites (Litherland et al. 1994).

A small-scale mosaic of different soil types has been documented at the RBSF (Schrumpf et al. 2001, Wilcke et al. 2001), reflecting the bedrock mosaic, but being also influenced by landslides and periglacial cover beds. Soils can generally be described as showing low exchange capacity, low $\mathrm{pH}$, thick organic layers and hydromorphic properties (Schrumpf et al. 1999, Wilcke et al. 2002). Accurate soil characterisation of the five study plots was done by S. Iost, TU Dresden.

Figure 2.6: Geology of the study area after Litherland et al. 1994 (changed from Beck et al. 2008).

The organic layer atop the mineral soil increases in thickness from about $50 \mathrm{~mm}$ at 1050 $\mathrm{m}$ to ca. $430 \mathrm{~mm}$ at $3060 \mathrm{~m}$ (Tab.2.2). Soil $\mathrm{pH}\left(\mathrm{CaCl}_{2}\right)$ decreases from 3.9 to 2.9 while $\mathrm{C} / \mathrm{N}$ ratio increases within the $\mathrm{L} / \mathrm{Of}_{1}$ (22 to 63) along the slope (Tab.2.3). Particularly large $\mathrm{C} / \mathrm{N}$ ratios (46 to 63) were found in the uppermost organic horizons of the high elevation stands 4 and 5. The low rates of cation exchange capacity (CEC) of the $A_{h}$ horizon increased with elevation. Base saturation of the $A_{h}$ was also low, showing the smallest values between 1050 and $2340 \mathrm{~m}$ a.s.l. and reaching its maximum at $3060 \mathrm{~m}$. High Al saturation was found in the lowermost plots, decreasing with elevation in the $A_{h}$ horizons, but not in the $B$ horizons. Soil types according FAO were Alumic Acrisol on site \#1 and \#2, Gleyic Cambisol on \#3 and \#4 and Podzol at site \#5 (Tab.2.3, all data by Iost 2007). 
Table 2.3: Soil characteristics of the five study plots in South Ecuador.

\begin{tabular}{ccccccccccc}
\hline Plot Soil type & $\begin{array}{c}\text { Org. layer } \\
\text { thickness }\end{array}$ & $\mathrm{pH}$ & $\mathrm{C} / \mathrm{N}$ & \multicolumn{2}{c}{$\mathrm{CEC}$} & \multicolumn{2}{c}{ Base saturation } & \multicolumn{2}{c}{ Al saturation } \\
{$[\mathrm{mm}]$} & $\left(\mathrm{CaCl}_{2}\right)$ & $(\mathrm{L} / \mathrm{Of} 1)$ & $\begin{array}{c}(\mathrm{Ah}) \\
{\left[\mu \mathrm{eqg} \mathrm{g}^{-1}\right]}\end{array}$ & $\begin{array}{c}(\mathrm{Bv} / \underline{\mathrm{B} 1} / E) \\
{\left[\mu \mathrm{eq} \mathrm{g}^{-1}\right]}\end{array}$ & $\begin{array}{c}(\mathrm{Ah}) \\
{[\%]}\end{array}$ & $\begin{array}{c}(\mathrm{Bv} / \mathrm{B} 1 / E) \\
{[\%]}\end{array}$ & $\begin{array}{c}(\mathrm{Ah}) \\
{[\%]}\end{array}$ & $\begin{array}{c}(\mathrm{Bv} / \mathrm{B} 1 / E) \\
{[\%]}\end{array}$ \\
\hline 1 & $\begin{array}{c}\text { Alumic } \\
\text { Acrisol }\end{array}$ & 48 & 3.94 & 22 & 34.7 & 22.3 & 12.5 & 19.5 & 84.6 & 78.1 \\
2 & $\begin{array}{c}\text { Alumic } \\
\text { Acrisol }\end{array}$ & 243 & 3.90 & 29 & 26.4 & 23.3 & 7.5 & 7.5 & 91.7 & 90.6 \\
3 & $\begin{array}{c}\text { Gleyic } \\
\text { Cambisol }\end{array}$ & 305 & 3.52 & 28 & 60.6 & $\underline{15.0}$ & 6.8 & $\underline{11.7}$ & 85.9 & $\underline{86.2}$ \\
4 & $\begin{array}{c}\text { Gleyic } \\
\text { Cambisol }\end{array}$ & 214 & 3.26 & 46 & 58.2 & $\underline{59.2}$ & 6.8 & $\underline{4.9}$ & 62.0 & $\underline{80.5}$ \\
5 & Podzol & 435 & 2.86 & 63 & 64.7 & 11.0 & 22.7 & 21.8 & 23.8 & 50.2 \\
\hline
\end{tabular}

Soil classification (FAO system), organic layer thickness, $\mathrm{pH}\left(\mathrm{CaCl}_{2}\right)$ of the mineral topsoil $(0$ $30 \mathrm{~cm}), \mathrm{C} / \mathrm{N}$ ratio of the organic layer (L/Of1), Cation exchange capacity $(\mathrm{CEC})$, base saturation and $\mathrm{Al}$ saturation of the $\mathrm{A}_{\mathrm{h}}$ and $\mathrm{B}_{\mathrm{v}} / \mathrm{B} 1 / \mathrm{E}$ horizons, all data except organic layer thickness after Iost (2007).

Soil temperature, measured with simple thermo-elements, and volumetric water contents (VWC) were measured with TDR (Campbell Scientific, Inc., Logan, UT) in the middle of the organic layer and in $10 \mathrm{~cm}$ depth of the mineral soil of each plot. Temperature data were logged hourly, VWC data every six hours. Means of temperature of the organic layer were very similar to air temperature means, extremes being buffered especially where organic layer thickness was high (Tab.2.2). Only on site \#1 noticeable temperature fluctuation in the shallow organic layer and the mineral topsoil were recorded (see Appendix Fig.8.4 and 8.6); on all other sites intraday and seasonal fluctuations were very low. At some plots annual means of topsoil temperatures exceeded means of air temperature, presumably due to dark forest ground colours, which absorbed high amounts of global irradiance.

$1050 \mathrm{~m}$

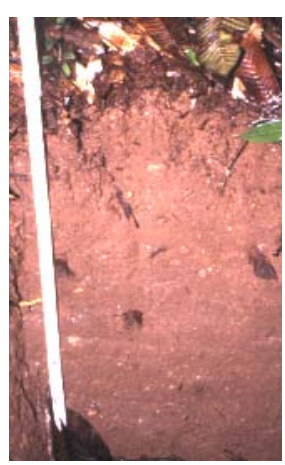

$1540 \mathrm{~m}$

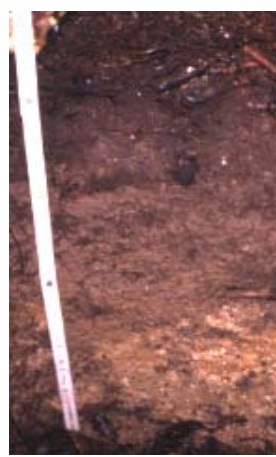

$1890 \mathrm{~m}$

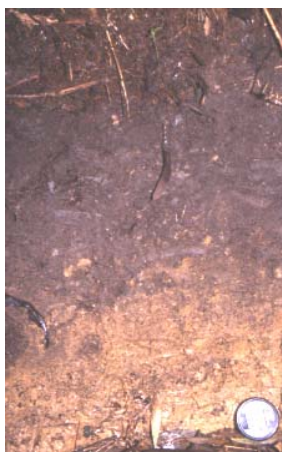

$2340 \mathrm{~m}$

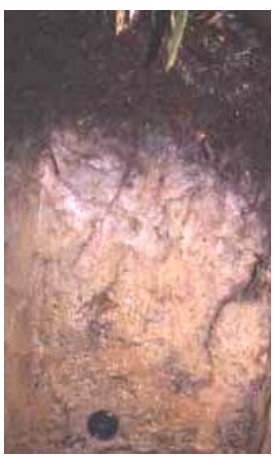

$3060 \mathrm{~m}$

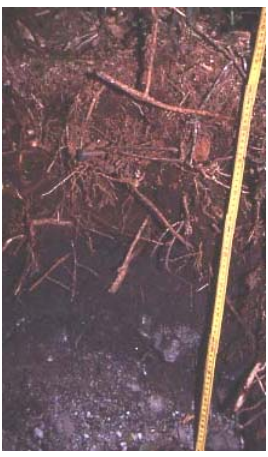

Figure 2.7: Soil profiles of the five study sites, dug by S. Iost, TU Dresden. 
Water content means in the organic layer of the lowermost three plots were below $12 \%$, while VWC in the organic layer of the uppermost forest sites and in the mineral topsoil of all stands were close to $30 \%$ or higher. Seasonal water content changes are visible in all five forest stands in the organic layer and the mineral topsoil (see Appendix, Fig.8.5 and 8.7). Minima of VWC at all plots were measured between the end of November 2003 and January 2004. Figure 2.7 gives an optical impression of the changes of soil properties along the elevation gradient.

\subsection{VEGETATION AT THE STUDY AREA}

While the lowermost stand $(1050 \mathrm{~m})$ is situated in the transition zone between tropical lowland and lower montane forest, the stands 2, 3 and 4 are in the lower to upper montane belt (bosque siempreverde montano, Balslev \& Ollgaard 2002; bosque de neblina montano,Valencia et al. 1999). Stand $5(3060 \mathrm{~m})$ is situated close to the tree line that is found at $3200-3400 \mathrm{~m}$ in the Loja/Zamora region. This stand is a typical 'elfin forest' with stunted tree growth. Patches of alpine paramo are found about $200 \mathrm{~m}$ upslope of this site.

The Cordillera Real is part of the so called Amotape-Huancabamba Floristic Zone between $3^{\circ} \mathrm{S}$ and $7^{\circ} \mathrm{S}$ (Weigend 2002), where an Andean timberline depression occurs. It is presented by an upper timberline rich in tree species (Fig.2.8). Very few peaks of the Andean chain in this region transgress $4000 \mathrm{~m}$ a.s.1. and only one isolated stand of Polylepis weberbaueri is known from the south of this section $\left(6^{\circ} \mathrm{S}\right.$ at around $3300 \mathrm{~m}$, Baumann 1988). This timberline depression results from the absence of the usually superposing Polylepis-belt.

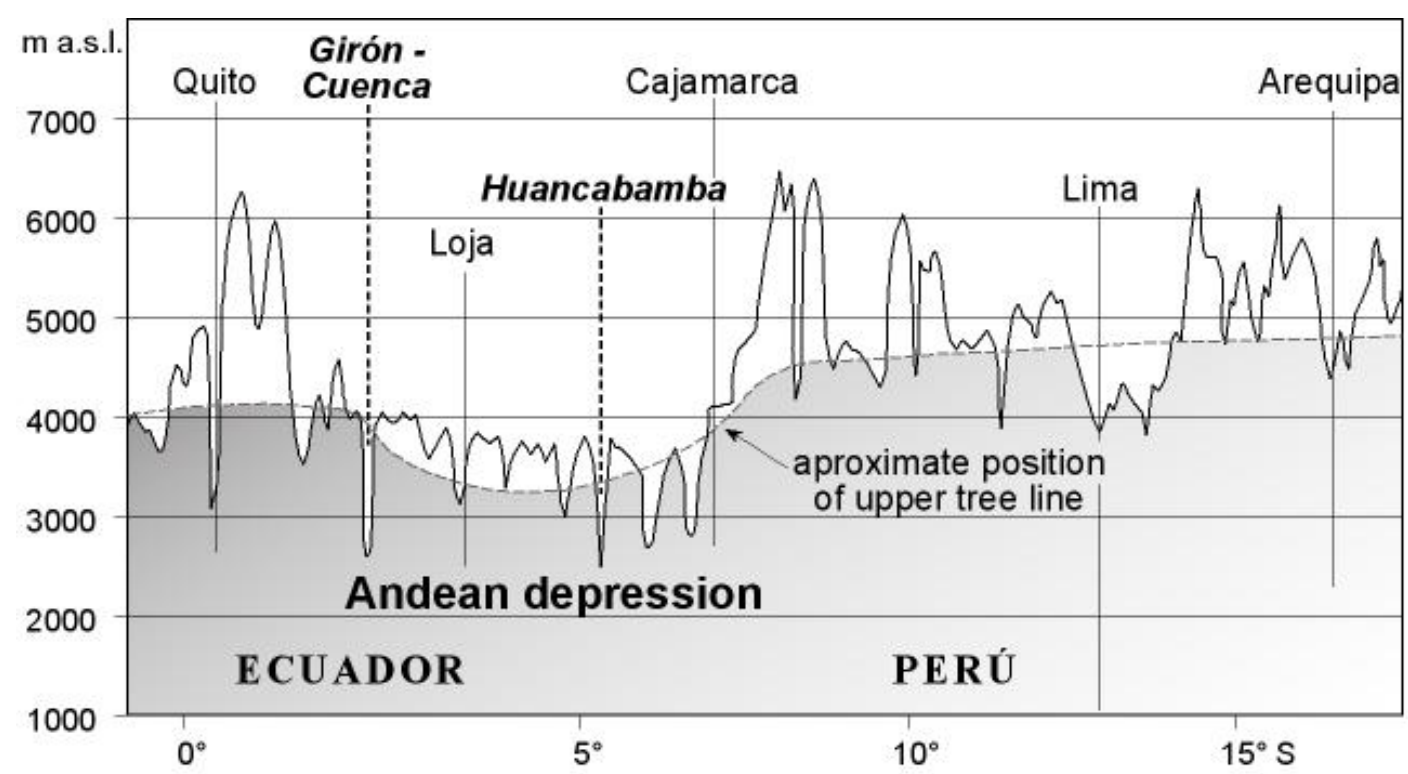

Figure 2.8: Position of upper tree line within the Neotropical section of the Andes (western escarpment of the main chain), from Richter et al. (2008).

The "Polylepis gap" is combined with extremely high precipitation in the eastern chain of the cordilleras in northern Perú and southern Ecuador. The genus tends to avoid 
perhumid mountain regions (Kessler 1995), but the drier western chain does not offer sufficient elevation for Polylepis-growth.

Table 2.3: Vegetation composition with respect of plant families of trees in the five study plots.

\begin{tabular}{lccccc}
\hline Plant families & $\mathbf{1}$ & $\mathbf{2}$ & $\mathbf{3}$ & $\mathbf{4}$ & $\mathbf{5}$ \\
\hline Melastomataceae & 2.5 & 40 & 31.3 & 16.3 & 5 \\
Myrtaceae & 6.3 & 1.3 & & 1.3 & 2.5 \\
Lauraceae & 2.5 & 11.3 & 12.5 & 3.8 & \\
Araliaceae & 1.3 & & 2.5 & 7.5 & 1.3 \\
Rubiaceae & 1.3 & 3.8 & 5 & & 15 \\
Chloranthaceae & & 2.5 & 2.5 & 3.8 & 2.5 \\
Styracaceae & & & & & 2.5 \\
Ericaceae & & & & & 7.5 \\
Cunoniaceae & & & & 1.3 & 23.8 \\
Symplocaceae & & & & 1.3 & 5 \\
Aquifoliaceae & & & 2.5 & 8.8 & 7.5 \\
Clusiaceae & & 1.3 & & 6.3 & 10 \\
Cyrillaceae & & & & 16.3 & \\
Gentianaceae & & & & 1.3 & \\
Lecythidaceae & & & & 1.3 & \\
Podocarpaceae & & & 1.3 & 10 & \\
Myrsinaceae & & 1.3 & 1.3 & 1.3 & \\
Euphorbiaceae & 1.3 & & 7.5 & & \\
Monimiaceae & & & 3.8 & & \\
Sapindaceae & & & 5 & & \\
Clethraceae & & & 5 & & \\
Alzatheaceae & & & 1.3 & & \\
Dubiaceae & & & 3.8 & & \\
Arecaceae & & 5.3 & & & \\
Burseraceae & & 3.8 & & & \\
Theaceae & & 1.3 & & & \\
Celastraceae & & 1.3 & & & \\
Annonaceae & & & & & \\
Cecropiaceae & 2.5 & & & & \\
Moraceae & & & & & \\
Mimosaceae & 5.3 & & & & \\
Sapotaceae & & & & & \\
Myristicaceae & & & & & \\
Not determined & & & & & \\
\hline
\end{tabular}

Relative contribution of the respective families in percent to a total of 80 trees surveyed per plot. Determination after J. Homeier, University of Göttingen.

The structure and floristics of the forests change considerably along the elevation gradient (Fig.2.9). However, the same plant life form (i.e. evergreen broad-leaved trees) occurs throughout. Important families of canopy trees of the respective stands are given in Table 2.3. In stand 1 trees of the family Myrtaceae, the genera Proteria cf. 
(Sapotaceae), Guatteria (Annonaceae), Ficus (Moraceae) and Inga (Mimosaceae) have been abandoned. Stand 2 consists mainly of trees of the genera Axinea and Miconia (Melastomaceae, $40 \%$ ), Beilschmiedia (Lauraceae, 10\%) and Euterpe (Arecaceae) indicating a ridge stand.

Graffenrieda emarginata and Miconia (Melastomataceae, $31 \%$ ) dominated stand 3; other common genera were Ocotea (Lauraceae, $13 \%$ ), Alchornia (Euphorbiaceae), Palicourea (Rubiacaea) and Clethra (Clethraceae). Important tree genera of stand 4 were Purdiaea (Cyrillaceae $16 \%$ ), various genera of Melastomataceae (16\%), Podocarpus oleifolia (Podocarpaceae, $10 \%$ ), Ilex (Aquifoliaceae), Schefflera (Araliaceae) and Clusia (Clusiaceae). Notable tree genera of stand 5 were Weinmannia (Cunoniaceae, $24 \%$ ), Faramea (Rubiaceae, $15 \%$ ), Clusia (Clusiaceae $10 \%$ ), Ilex (Aquifoliaceae), genera of Ericaceae and Symplocus (Symplocaceae).

Five families occurred in four plots and only the family Melastomataceae was present in all five stands. Most other families showed clear preferences with regard to their altitudinal occurrence.

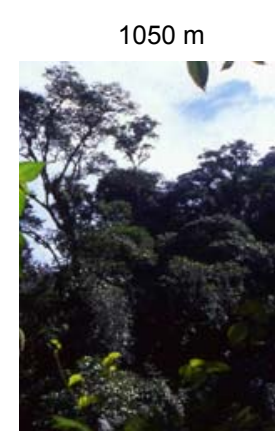

Lower Montane Rainforest

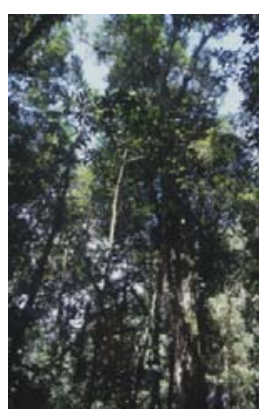

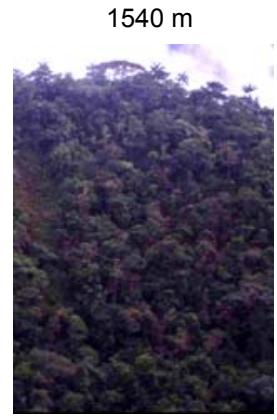

Montane Rainforest

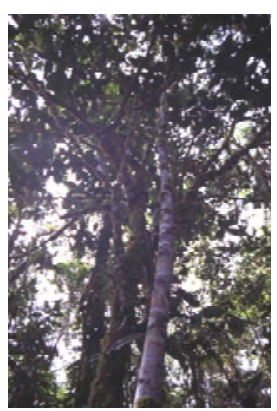

$1890 \mathrm{~m}$

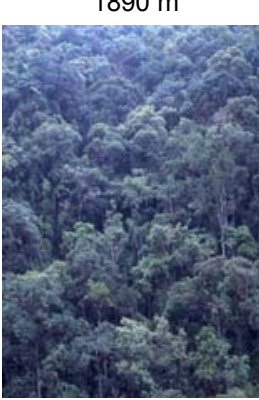

Montane Rainforest

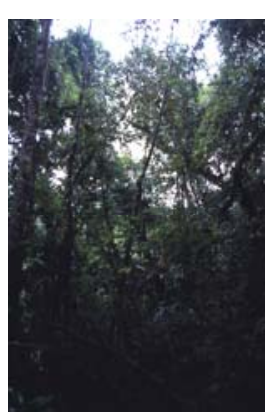

$2340 \mathrm{~m}$

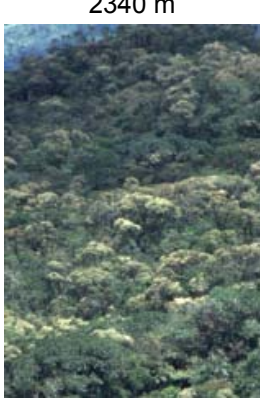

Upper Montane Rainforest

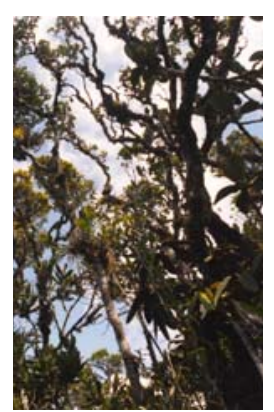

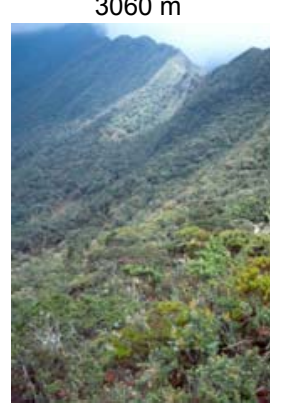

Elfin Forest

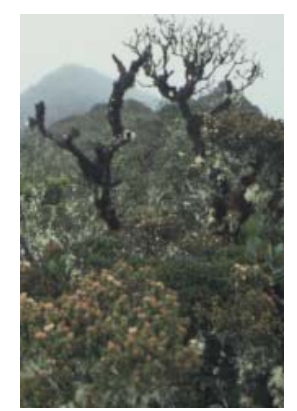

Figure 2.9: Views from outside and inside the five studied forest sites, giving an optical impression of the changing forest structure and species composition along the gradient

\subsection{REFERENCES}

Balslev, H., Øllgaard, B. 2002. Mapa de vegetación del sur de Ecuador. In: Aguirre, Z.M., Madsen, J.E., Cotton, E., Balslev H. (eds.). Botánica Austroecuatoriana Estudios sobre los recursos vegetales en las provincias de el Oro, Loja y ZamoraChinchipe, Ediciones ABYA YALA, Quito, pp. 51-64.

Baumann, F. 1988. Geographische Verbreitung und Ökologie südamerikanischer Hochgebirgspflanzen. Beitrag zu Rekonstruktion der quartären Vegetationsgeschichte der Anden. Physische Geographie 28, Zürich. 
Beck, E., Müller-Hohenstein, K. 2001. Analysis of undisturbed and disturbed tropical mountain forest ecosystem in Southern Ecuador. Die Erde 132: 1-8.

Beck, E., Makeschin, F., Haubrich, F., M. Richter, J. Bendix 2008. The Ecosystem (Reserva Biológica San Francisco). In: Beck, E., Bendix, J., Kottke, I., Makeschin F., Mosandl, R. (eds.). Gradients in a tropical mountain ecosystem of Ecuador. Springer Verlag, Berlin, Heidelberg, Ecological Studies 198, in press.

Bendix, J., Homeier, J, Ortiz, E.C., Emck, P., Breckle, S.W., Richter, M., Beck, E. 2006. Seasonality of weather and tree phenology in a tropical evergreen mountain rain forest. International Journal of Biometeorology 50: 370-384.

Bendix, J., Lauer, W. 1992. Die Niederschlagsjahreszeiten in Ecuador und ihre klimadynamisch Interpretation. Erdkunde 46: 118-134.

Bendix, J., Rollenbeck, R., Richter, M., Fabian, P., Emck, P. 2008. Gradual changes along the altitudinal gradient: climate. In: Beck, E., Bendix, J., Kottke, I., Makeschin F., Mosandl, R. (eds.). Gradients in a tropical mountain ecosystem of Ecuador. Springer Verlag, Berlin, Heidelberg, Ecological Studies 198, in press.

Calderón, S. 2002. El Parque Nacional Podocarpus y fundamentos legales que lo respaldan. In: Aguirre, M.Z., Madsen, J.E., Cotton, E., Balslev, H. (eds.). Botánica Austroecuatoriana, Estudios sobre los recursos vegetales en las provincias de El Oro, Loja y Zamora-Chinchipe. Ediciones Abya-Yala, Quito, Ecuador, pp. 433-451.

Fabian, P., Kohlpaintner, M., Rollenbeck, R. 2005. Biomass burning in the Amazon Fertilizer for the mountainous rain forest in Ecuador. Environmental Science and Pollution Research 12: 290-296.

Iost, S. 2007. Soil respiration, microbial respiration and mineralisation in soils of montane rainforests of Southern Ecuador: influence of altitude. Dissertation TU Dresden, pp. 171.

Kessler, M. 1995. Polylepis-Wälder Boliviens: Taxa, Ökologie, Verbreitung und Geschichte. Dissertationes Botaniceae 246.

Litherland, M., Aspden, J., Jemielita, R. 1994. The metamorphic belts of Ecuador. No. 11 in Overseas Memoir of the British Geological Survey, Keyworth, U.K.

Maldonado, N.P.A. 2002. Clima y vegetación de la región sur del Ecuador. In: Aguirre, Z.M., Madsen, J.E., Cotton, E., Balslev, H. (eds.). Botánica Austroecuatoriana, Estudios sobre los recursos vegetales en las provincias de El Oro, Loja y ZamoraChinchipe. Ediciones Abya Yala, Quito, Ecuador, pp. 1-28.

Richter, M. 2003. Using epiphytes and soil temperatures for eco-climatic interpretations in Southern Ecuador. Erdkunde 57 (3): 161-181.

Richter, M., Diertl, K.-H., Bussmann, R.W., Peters, T. 2008. Vegetation structures and ecological features of the upper tree line ecotone. In: Beck, E., Bendix, J., Kottke, I., Makeschin F., Mosandl, R. (eds.). Gradients in a tropical mountain ecosystem of Ecuador. Springer Verlag, Berlin, Heidelberg, Ecological Studies198, in press.

Schrumpf, M. 1999. Genese, Klassifikation und Nährstoffgehalte tropischer Böden entlang eines Höhentransektes an der Andenostabdachung Südecuadors. Diploma thesis, University Bayreuth, Germany.

Schrumpf, M., Guggenberger, G., Valarezo, C. \& Zech, W. 2001. Tropical montane rain forest soils. Development and nutrient status along an altitudinal gradient in the South Ecuadorian Andes. Die Erde 132: 43-59.

Unger, M. 2005. Veränderung blattchemischer und-morphologischer Eigenschaften von Bäumen im tropischen Regenwald Südecuadors in Abhängigkeit vom 
Strahlungsregime in einem Höhentransekt. Diplom thesis. University Göttingen. pp.80.

Valencia, R., Ceron, C., Palacios, W., Sierra, R. (1999). Las formaciones naturales de la sierra del Ecuador. In: R. Sierra (Ed.), Propuesta preliminar de un sistema de clasificacion de vegetacion para el Ecuador continental (79-108). Proyecto INEFAN/GEF-BIRF y EcoCiencia, Quito.

Walter, H., Breckle, S.-W. 2004. Ökologie der Erde. Band 2 Spezielle Ökologie der Tropischen und Subtropischen Zonen. 3.Aufl. Elsevier.

Weigend, M. 2004. Additional observations on the biogeography of the AmotapeHuancabamba Zone in northern Peru: defining the southeastern limits. Revista Peruana Biologica 11(2): 127-134.

Whitmore, T.C. 1998. An introduction to tropical rain forests. Oxford Univ. Press, 2nd ed.

Wilcke, W., Yasin, S., Valarezo, C., Zech, W. 2001. Change of water quality during the passage through a tropical montane rain forest in Ecuador. Biogeochemistry 55: 4572.

Wilcke, W., Yasin, S., Schmitt, A., Valarezo, C., Zech, W. 2002. Nutrient storage and turnover in organic layer under tropical montane rain forest in Ecuador. European Journal of Soil Science 53:15-27. 



\section{ALTITUDINAL CHANGES IN STAND STRUCTURE AND BIOMASS ALLOCATION \\ OF TROPICAL MOUNTAIN FORESTS IN \\ RELATION TO MICROCLIMATE \\ AND SOIL CHEMISTRY*}

A TRANSECT STUDY IN ECUADOR AND A NEOTROPICAL META-ANALYIS

\subsection{INTRODUCTION}

In tropical montane forests, the decline of tree size with increasing elevation is a well recognized phenomenon (Lieberman et al. 1996, Raich et al. 1997). The decrease aligns with a continuous species shift from lowland forests, to lower, middle and upper montane forests (Gentry et al. 1995). Leaf area index (LAI) also decreases with elevation from lowland to upper montane forest (Kitayama \& Aiba 2002).

With respect to other structural and functional parameters such as plant biomass and productivity, however, only very limited data exist from tropical montane forests. Elevational changes in aboveground biomass and productivity were studied in transects in Malaysia (Kitayama \& Aiba 2002), Hawaii (Raich et al. 1997), Puerto Rico (Weaver \& Murphy 1990) and Jamaica (Tanner 1980), some of them covering only a few hundred meter of elevational distance. The data base is even more limited if belowground biomass is considered: for example, a combined assessment of above- and belowground biomass in neotropical montane forests has been conducted in not more than 16 different stands so far, and only exceptionally included elevational transects.

A better understanding of the causes of tree size reduction with elevation in tropical mountains is closely linked to information on altitudinal changes in biomass, carbon allocation and productivity of montane forests. Although numerous hypotheses focussing on climatic or edaphic constraints of tree growth have been formulated in order to explain this phenomenon (e.g. Bruijnzeel \& Proctor 1995, Flenley 1995), all of them are eventually linked to carbon gain and allocation of the trees and their control by the environment. Thus, tree biomass and productivity data are of paramount importance.

In this study we present detailed above- and belowground biomass data of an altitudinal transect study in the Ecuadorian Andes and complement them with data from other forest biomass inventories of the humid Neotropics. Study aim was to analyse altitudinal changes in forest biomass and tree root/shoot ratio, and to relate them to possible underlying climatic and edaphic factors.

\footnotetext{
${ }^{*}$ published in a slightely changed and shortened version (without meta-analysis): G. Moser, M. Röderstein, N. Soethe, D. Hertel and Ch. Leuschner 2008. In: Beck, E., Bendix, J., Kottke, I., Makeschin, F., Mosandl, R. (eds.) Gradients in a tropical mountain ecosystem of Ecuador. Springer Verlag, Berlin Heidelberg, Ecological studies 198: 229-242. With kind permission of (C) Springer Verlag.
} 


\subsection{STUDY SITES}

This analysis is based on an in-depth study in five forest stands along a 2000-m altitudinal gradient in South Ecuador between $1050 \mathrm{~m}$ and $3060 \mathrm{~m}$ a.s.1., at a maximum distance of the stands to each other of $30 \mathrm{~km}$. The lowermost stands 1 and 2 are within the Podocarpus National Park close to the entrance in Bombuscaro, south of the province capital Zamora. Stands 3 and 4 are located in the RBSF. Stand 5 is an elfin forest located in the Cajanuma area at the northwestern gate of the National Park. Patches of alpine Paramo are found about $200 \mathrm{~m}$ upslope of this stand.

The sites are situated on moderately steep slopes facing northeast to northwest, except for site 2 (Tab. 3.1). The study plots of $20 \times 20 \mathrm{~m}$ were selected in parts of the forests that were representative for the respective forest types and elevations characterized by Balslev \& Øllgaard (2002). All stands were selected in areas with no or only minimal signs of human influence as indicated by a more or less homogenous canopy structure. All stands had closed canopies with no larger gaps in direct proximity to the study plots.

Table 3.1: Location and characteristics of the five study plots in South Ecuador

\begin{tabular}{|c|c|c|c|c|c|c|c|c|}
\hline Plot & Coordinates & $\begin{array}{c}\text { Elevation } \\
\text { m a.s.l. }\end{array}$ & 。 & $\begin{array}{c}\mathbf{p H} \\
\mathrm{CaCl}_{2}\end{array}$ & $\begin{array}{l}\text { C/N } \\
\text { L/Of1 }\end{array}$ & Soil type & $\begin{array}{c}\text { Org. layer } \\
\text { thickness } \\
\quad m m\end{array}$ & $m m y r^{-1}$ \\
\hline 1 & $\begin{array}{l}\text { S } 04^{\circ} 06^{\prime} 54^{\prime \prime} \\
\text { W } 78^{\circ} 58^{\prime} 02^{\prime \prime}\end{array}$ & 1050 & 26 & 3.94 & 22 & $\begin{array}{l}\text { Alumic } \\
\text { Acrisol }\end{array}$ & 48 & c. 2230 \\
\hline 2 & $\begin{array}{l}\text { S } 04^{\circ} 06^{\prime} 42^{\prime \prime} \\
\text { W } 78^{\circ} 58^{\prime} 20^{\prime \prime}\end{array}$ & 1540 & 10 & 3.90 & 29 & $\begin{array}{l}\text { Alumic } \\
\text { Acrisol }\end{array}$ & 243 & c. 2300 \\
\hline 3 & $\begin{array}{l}\text { S } 03^{\circ} 58^{\prime} 345^{\prime \prime} \\
\text { W } 79^{\circ} 04^{\prime} 648^{\prime \prime}\end{array}$ & 1890 & 31 & 3.52 & 28 & $\begin{array}{c}\text { Gleyic } \\
\text { Cambisol }\end{array}$ & 305 & c. 1950 \\
\hline 4 & $\begin{array}{l}\text { S } 03^{\circ} 59^{\prime} 19^{\prime \prime} \\
\text { W } 79^{\circ} 04^{\prime} 55^{\prime \prime}\end{array}$ & 2380 & 28 & 3.26 & 46 & $\begin{array}{c}\text { Gleyic } \\
\text { Cambisol }\end{array}$ & 214 & c. 5000 \\
\hline 5 & $\begin{array}{l}\text { S } 04^{\circ} 06^{\prime} 71^{\prime \prime} \\
\text { W } 79^{\circ} 10^{\prime} 581^{\prime \prime}\end{array}$ & 3060 & 27 & 2.86 & 63 & Podzol & 435 & c. 4500 \\
\hline
\end{tabular}

$\mathrm{pH}\left(\mathrm{CaCl}_{2}\right)$ of the mineral topsoil $(0-30 \mathrm{~cm}), \mathrm{C} / \mathrm{N}$ ratio of the organic layer (L/Of1) and soil classification (FAO system), after S. Iost (unpubl.). Rainfall data are extrapolated from measurements in gaps at 1050 (own measurement), 1950, 2680 and $3170 \mathrm{~m}$ done by P. Emck (unpubl.).

Precipitation principally increases with elevation from $1050 \mathrm{~m}$ to $3060 \mathrm{~m}$ (Tab. 3.1; P. Emck and M. Richter, unpublished data; see Bendix et al. 2008). The soil types change along the gradient due to changes of bedrock and hydrology (see Chapter 2, Beck et al. 2008). The mineral topsoil is generally acid and $\mathrm{pH}\left(\mathrm{CaCl}_{2}\right)$ decreases with elevation. There is a general, but not continuous, increase in depth of the ectorganic layer with elevation; in parallel, the $\mathrm{C} / \mathrm{N}$ ratio of the organic layer increases as well (more details on soil conditions see Iost et al. 2008; Wilcke et al. 2008).

Canopy trees belonging to the Melastomataceae occurred in all elevations while five additional plant families were present at least in four of the five plots. Most other families showed clear preferences in their altitudinal distribution. 


\subsection{MethodS}

\subsubsection{MICROCLIMATE AND SOIL CHEMICAL AND SOIL MOISTURE MEASUREMENTS}

In all five stands, air temperature and relative air humidity ( $1.5 \mathrm{~m}$ above ground), as well as soil temperature and soil moisture (in the organic layer and in $10 \mathrm{~cm}$ of mineral soil) were measured continuously in the study period (April 2003 to April 2004). Air temperature and air humidity were measured once per hour with a Hygroclip $S$ temperature and humidity sensor (Rotronic AG, Bassersdorf, Switzerland). Soil temperature was measured in the middle of the organic layer and at a depth of $10 \mathrm{~cm}$ in the mineral soil and was recorded once per hour. Soil moisture was determined as volumetric water content by TDR sensors (Campbell Scientific Inc.) in the same depths as soil temperature and was read by data loggers (CR 10X, Campbell Scientific Inc., Logan, UT, USA) every $6 \mathrm{~h}$. Given are means, maximum and minimum values for the period April 2003 to March 2004.

Soil $\mathrm{pH}\left(\mathrm{CaCl}_{2}\right)$ and $\mathrm{C} / \mathrm{N}$ ratio were measured in the same horizons by $\mathrm{S}$. Iost (see Iost et al. 2008).

\subsubsection{ANALYSIS OF STAND STRUCTURE}

Tree biometric data were investigated in populations of each 80 trees per stand that covered $827 \mathrm{~m}^{2}, 360 \mathrm{~m}^{2}, 343 \mathrm{~m}^{2}, 290 \mathrm{~m}^{2}$ and $96 \mathrm{~m}^{2}$ (in horizontal projection) of the stands 1, 2, 3, 4 and 5, respectively. Thus, the size of the inventory plots decreased upslope due to increasing stem density. All trees reaching the canopy were investigated for stem length and diameter at breast height $(\mathrm{DBH}$, at $1.3 \mathrm{~m})$. Stem length and tree height were measured independently because many trees did not grow in erect position. We did not exclude trees of a certain DBH if they reached the canopy. Therefore, at $3060 \mathrm{~m}$ elevation, trees with a DBH as small as $3 \mathrm{~cm}$ were included, while $5 \mathrm{~cm}$ was the minimum DBH at $1050 \mathrm{~m}$ a.s.l.

Tree height was measured with a Vertex III Forestor tree height meter (Haglöf, Långsele, Sweden). The angle of the stems was also recorded for calculating total stem length in the steeply sloped stands; this data was then used for stem biomass calculation. To monitor the $\mathrm{DBH}$ of trees at consecutive occasions, measuring tapes made of astralon with an accuracy of $0.01 \Pi \mathrm{x} \mathrm{cm}$ (D1, UMS GmbH, Munich, Germany) were installed. The tapes were mounted under all vines or roots on the stem surface. To reduce measuring errors we controlled and read the dendrometer tapes twice a week. Trees with buttresses occurred only at site 1 , and none reached a stem height of $1.3 \mathrm{~m}$.

After projecting the 80-tree inventory plots on the horizontal plane, we calculated stem density and basal area, the latter being the sum of the cross-sectional areas of all trees derived from DBH. For measuring stem wood density (specific gravity), we extracted samples of stem wood with a stem corer ( $5 \mathrm{~mm}$ in diameter, Haglöf, Långsele, Sweden) at $1.5 \mathrm{~m}$ height by coring from the bark to the centre of the bole. This was done in 20 trees per plot which were randomly selected out of the 80 -tree sample. We measured the length of the core for each wood sample and calculated the sample volume. After drying of the wood samples (four days at $70^{\circ} \mathrm{C}$ ) in the ECSF laboratory, we measured dry mass and calculated the dry wood density as dry mass per green wood volume.

Leaf area index (LAI) was estimated by each 10 measurements per plot at random positions with a LAI-2000 system (LICOR, Lincoln, Nebraska, USA). 


\subsubsection{ESTIMATION OF ABOVEGROUND BIOMASS}

Aboveground tree biomass was estimated with allometric equations for the 80 canopy trees per plot based on the measured DBH and tree height data. We ignored understorey trees and shrubs, and standing or lying dead trunks (see Wilcke et al. 2005) since understorey biomass in mature moist tropical forests may comprise less than $3 \%$ of the aboveground biomass (Brown 1997).

We screened the literature for allometric equations available for the humid tropical moist forests. In the 38 relevant studies we found 184 different allometric equations for total aboveground tree biomass or different fractions of it (see Appendix, List I), not including lianas (see Gerwing et al 2006, Schnitzler et al. 2006). The only allometric equation that seems to exist for Andean mountain forests was developed for a cloud forest in Venezuela (Brun 1976) with a high specifity to the local conditions in that forest. Since specific equations applicable for lower to upper tropical montane forests have only been established for Malaysia (Yamakura et al. 1986), Jamaica (Tanner 1980), and Hawaii (Raich et al. 1997), we tested the pan-tropical equations established by Brown \& Iverson (1992) and Chave et al. (2005) for estimating aboveground tree biomass only.

The pan-tropical equation of Brown and Iverson (1992) bases on DBH and tree height data; the equation of Chave et al. (2005) additionally considers wood specific density which can significantly improve the accuracy of biomass estimation from allometric regressions (Chave et a. 2004). These pan-tropical equations may be applicable to the whole range of Andean mountain forest types from the lower to the upper montane vegetation belt. The equations were developed for estimating the total aboveground biomass including leaves, twigs, branches, bark and boles of trees, based on data of 169 (Brown and Iverson 1992) or 2410 (Chave et al. 2005) harvested trees from all over the tropics.

The applicability of the allometric equations to our stands was assessed with three recently wind-thrown tree individuals per study site, which were analyzed for stem length, DBH, wood volume and specific wood gravity. Due to best fit to these empirical data we selected the allometric equation of Chave et al. (2005):

$$
\mathrm{AGB}=\exp \left(-2.557+0.940 \ln \left(\sigma \mathrm{D}^{2} \mathrm{H}\right)\right)
$$

where $A G B$ is tree aboveground biomass ( $\mathrm{kg}$ per tree), $D$ is $\mathrm{DBH}(\mathrm{cm}), H$ is stem height (m) and $\sigma$ is wood density $\left(\mathrm{g} \mathrm{cm}^{-3}\right)$. The stand aboveground biomass total (AGB) was obtained by summing up the calculated masses of the 80 trees per plot.

\subsubsection{ROOT SAMPLING AND ANALYSIS}

Coarse root biomass for each stand was determined at $12-16$ soil pits $(40 \times 40 \mathrm{~cm})$ that were dug to $60 \mathrm{~cm}$ soil depth. Biomass (live roots) and necromass (dead roots) of all roots with a diameter $>2 \mathrm{~mm}$ were excavated in steps of $10 \mathrm{~cm}$ horizons in the organic layer and the mineral soil. In the laboratory, all roots were washed and dried at $70^{\circ} \mathrm{C}$ to constant dry mass.

For analysing bio- and necromass of fine root (diameter $<2 \mathrm{~mm}$ ), soil coring was conducted from March to May 2003 in soil profiles of $30 \mathrm{~cm}$ depth (organic layer and the mineral soil) under the five stands. Preliminary investigations of a lower number of 
soil cores to $60-80 \mathrm{~cm}$ depth revealed that the organic layer and the mineral soil to $30 \mathrm{~cm}$ depth must contain about $75 \%$ or more of the profile total of tree fine root biomass since fine root densities in the subsoil were very low. Subsequently, profile totals of root biomass refer to the organic layer and the mineral soil to $30 \mathrm{~cm}$ depth which were investigated in this study.

Root sampling was conducted with a steel corer ( $33 \mathrm{~mm}$ in diameter, $\mathrm{n}=20$ per plot). The soil material was stored at $4{ }^{\circ} \mathrm{C}$ in the laboratory at Estación Científica San Francisco where processing took place within 30 days. Fine root biomass and necromass were separated under a microscope according to the procedure described by Leuschner et al. (2001).

\subsubsection{ALTITUdINAL CHANGE OF STAND STRUCTURE AND BIOMASS IN NEOTROPICAL FORESTS - A LITERATURE REVIEW}

To place the forest biomass data from South Ecuador in a broader context, we conducted a literature survey on tree height, $\mathrm{DBH}$, basal area, stem density and aboveand belowground biomass data of humid neotropical forests from a broad range of elevations. All data from lowland or montane forests were included if the forest inventory covered the stems with a minimum DBH of $10 \mathrm{~cm}$ or smaller. Consequently the minimum DBH varied between 2.5 and $10 \mathrm{~cm}$ in the studies, thereby introducing a certain bias in the stand structure and biomass data. The review covers 66 studies with altogether 267 forest sites (see Appendix, List II); 59 data points were available for mean tree height, 67 for mean $\mathrm{DBH}, 150$ for basal area, 224 for stem density, 92 for tree aboveground biomass (AGB), and 16 for total root biomass (BGB); the latter were used to calculate root/shoot ratio.

\subsubsection{STATISTICAL ANALYSIS}

Differences of stem length, DBH, wood density, LAI and leaf biomass among the five Ecuadorian stands were analyzed with a non-parametric analysis of variance (KruskalWallis test) and a Mann-Whitney two-sample test ( $U$ test) using the SAS ver. 8.2 package (SAS Institute, USA).

Linear and simple non-linear regression analyses were applied to identify significant effects of elevation, mean air temperature, VPD, mean annual precipitation, mineral soil moisture, mineral soil proton concentration and $\mathrm{C} / \mathrm{N}$ ratio of the organic layer on tree height, DBH, basal area, stem density, aboveground biomass, belowground biomass, total biomass and root/shoot biomass ratio. All calculations were done using Xact ver. 8.0 software (SciLab, Germany).

\subsection{RESULTS}

\subsubsection{ALTITUDINAL CHANGE OF STAND MICROCLIMATE}

The annual mean air temperature inside the forest stands at $1.5 \mathrm{~m}$ above the forest floor decreased between $1050 \mathrm{~m}$ and $3060 \mathrm{~m}$ with a temperature lapse rate of $5 \mathrm{~K} \mathrm{~km}^{-1}$ (Tab.15.2). The annual mean of relative air humidity inside the stands increased slightly along the transect revealing a significant positive correlation with elevation 
$\left(y=85.8+0.003 \mathrm{x}, \mathrm{r}_{\mathrm{adj}}^{2}=0.85, \mathrm{p}=0.008\right)$. The corresponding vapor pressure deficit decreased from $1050 \mathrm{~m}$ to $3060 \mathrm{~m}\left(y=3.9-0.009 \mathrm{x}, \mathrm{r}^{2}{ }_{\text {adj }}=0.93, \mathrm{p}=0.002\right)$. VPD extremes exceeded $3 \mathrm{kPa}$ in stands 1 and 3, but were lower in stands 2, 4 and 5 .

Annual mean temperature of the organic layer was between $0.3^{\circ} \mathrm{C}$ and $1.7^{\circ} \mathrm{C}$ higher than mean air temperature in all stands (Tab.2.1); that of the mineral topsoil was very close to air temperature.

Average soil moisture of the organic layer and the mineral topsoil increased greatly between plots 1 and 5; the seasonal minima in the organic layer of stands 1-3 were quite low due to the small depth of this horizon. The seasonal minima in the mineral soil were not as low as in the organic layer and water shortage did not occur (Tab.2.1).

\subsubsection{ALTITUDINAL CHANGE OF STAND STRUCTURE}

Canopy height declined 3.5-fold and mean stem length 3.0-fold between $1050 \mathrm{~m}$ and $3060 \mathrm{~m}$ (Tab.3.2). In the uppermost stand (\#5) in the elfin forest, strongly inclinated trunks with low canopy height were responsible for the relatively high maximum stem length (Tab.3.2). Tree height showed a very close correlation to both elevation and temperature; however, VPD, soil moisture, soil proton concentration and $\mathrm{C} / \mathrm{N}$ ratio of the organic layer had significant effects on tree height as well (Tab.3.3).

We found a 8.6-fold decrease in maximum DBH and in mean DBH by a factor of 2.5 between stand 1 and stand 5 which is roughly proportional to the 3.0 -fold reduction in mean stem length, but contrasts with an 8.6-fold increase of stem density along the 2000 $m$ elevation transect. Mean DBH correlated significantly with elevation, air temperature and $\mathrm{C} / \mathrm{N}$ ratio of the organic layer (Tab.3.3). The lowermost plot (\#1) was the only stand where trees with a DBH $>30 \mathrm{~cm}$ occurred, but the most frequent DBH class was the 10 $20 \mathrm{~cm}$ class. More upslope, the DBH class of 5-10 cm included the highest number of canopy trees. At the two uppermost sites (stands 4, 5), a higher number of trunks belonged to the $3-5 \mathrm{~cm}$ DBH class than to the $10-20 \mathrm{~cm}$ class (Tab.3.2).

Stand basal area is a function of mean DBH and stem density which both showed opposite trends with elevation in South Ecuador. In this transect, we found no clear altitudinal dependence of basal area although the highest value was measured at the uppermost stand (Tab.3.2). It correlated neither with elevation nor temperature, and was not influenced by any of the soil parameters (Tab.3.3).

Stem wood specific gravity did not differ significantly between the five studied stands and did not correlate with elevation (Tab.3.2) and leaf area index decreased continuously with elevation (Tab.3.3).

\subsubsection{ALTITUDINAL CHANGE OF TREE BIOMASS}

Total aboveground tree biomass (AGB) declined 2.5-fold from plot 1 to plot 5 and was significantly dependent on elevation (Tab.3.3). In stand 1, trees with a DBH $>30 \mathrm{~cm}$ accounted for more than two-thirds of the total aboveground tree biomass. In contrast, in all other stands, trees with a DBH of 10-20 cm were responsible for the largest portion of AGB. Trees with a DBH $<5 \mathrm{~cm}$ contributed only at plot 5 more than $1 \%$ of the aboveground tree biomass. AGB was highly dependent on the $\mathrm{C} / \mathrm{N}$ ratio of the organic layer, but was also related to mean air temperature and soil moisture (Tab.3.3). 


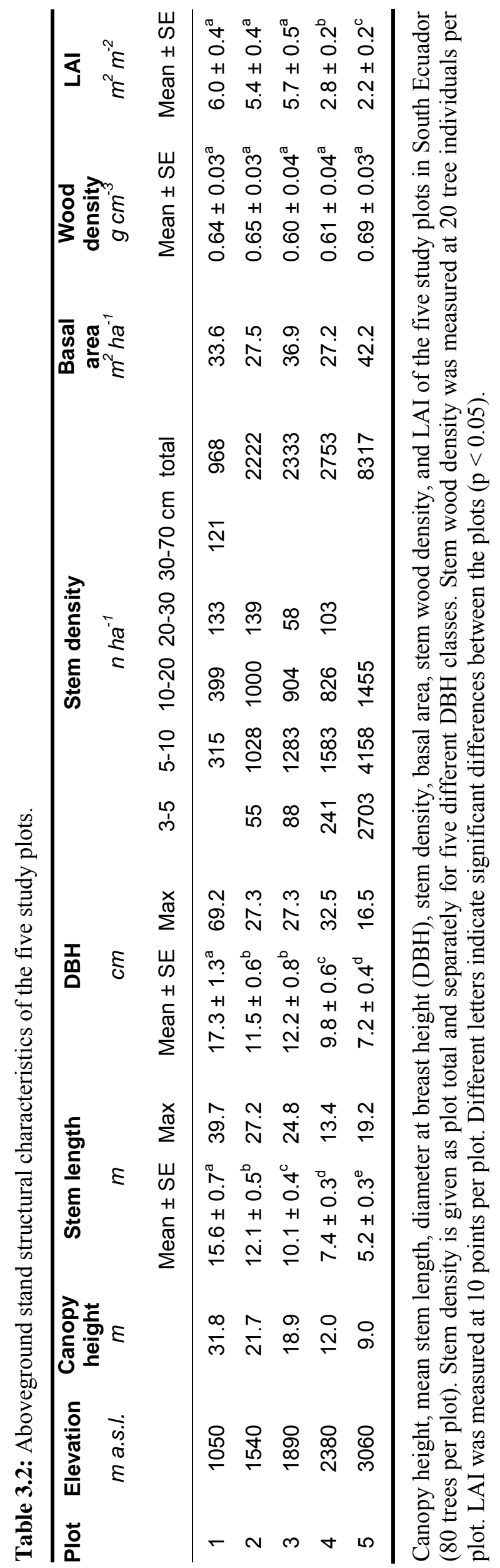

-29 - 


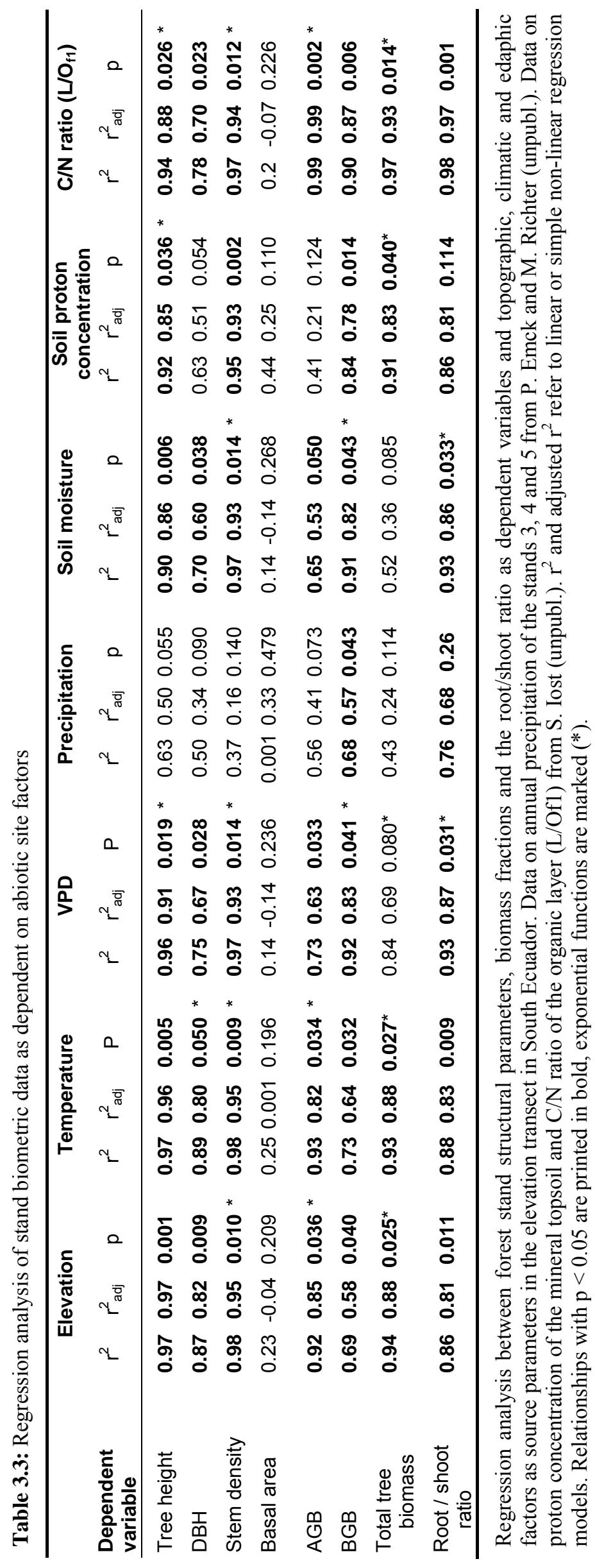


Table 3.4: Aboveground, belowground, total biomass and root/shoot ratio of the five stands in South Ecuador

\begin{tabular}{|c|c|c|c|c|c|c|c|c|c|c|}
\hline \multirow[t]{3}{*}{ Plot } & \multirow{3}{*}{$\begin{array}{c}\text { Elevation } \\
m \text { a.s.l. }\end{array}$} & \multirow{2}{*}{\multicolumn{6}{|c|}{$\begin{array}{c}\text { AGB } \\
M g h a^{-1}\end{array}$}} & \multirow{3}{*}{$\begin{array}{c}\text { BGB } \\
M g h a^{-1}\end{array}$} & \multirow{3}{*}{$\begin{array}{c}\text { Total biomass } \\
\qquad M g h a^{-1}\end{array}$} & \multirow[t]{3}{*}{ Root/shoot } \\
\hline & & & & & & & & & & \\
\hline & & $3-5$ & $5-10$ & $10-20$ & $20-30$ & $30-70 \mathrm{~cm}$ & Total & & & \\
\hline 1 & 1050 & & 7.7 & 40.9 & 41.1 & 195.3 & 285.1 & 32.1 & 317.2 & 0.113 \\
\hline 2 & 1540 & 0.4 & 19.8 & 97.3 & 50.0 & & 167.5 & 36.3 & 203.8 & 0.217 \\
\hline 3 & 1890 & 0.4 & 22.4 & 119.4 & 30.8 & & 173.0 & 25.8 & 198.8 & 0.149 \\
\hline 4 & 2380 & 0.8 & 19.1 & 49.8 & 7.2 & 22.9 & 99.8 & 39.2 & 139.0 & 0.393 \\
\hline 5 & 3060 & 8.8 & 51.1 & 52.3 & & & 112.2 & 62.7 & 174.9 & 0.559 \\
\hline
\end{tabular}

Estimates of total aboveground tree biomass (AGB) are based on an allometric equation given by Chave et al. (2005), which relates biomass to tree height, DBH and wood density. Given are AGB values for five different DBH classes. Belowground biomass (BGB) is given as the sum of coarse root biomass (diameter $>2 \mathrm{~mm}$ ) and fine roots (diameter $<2 \mathrm{~mm}$ ). Total biomass is the sum of AGB and BGB. The root/shoot biomass ratio was calculated as the BGB/AGB quotient.

Total aboveground tree biomass significantly decreased with altitude in the Ecuadorian transects (Tab.3.4). The portion of belowground biomass in total tree biomass increased from $10.1 \%$ to $35.8 \%$ between the lowermost and the uppermost stand. A five-fold increase in the root/shoot ratio of the trees between $1050 \mathrm{~m}$ and $3060 \mathrm{~m}$ in the Ecuador transect underlines the large carbon allocation shift from aboveground to belowground tree organs that takes place along this slope (Fig.3.2). Root/shoot ratio was correlated to

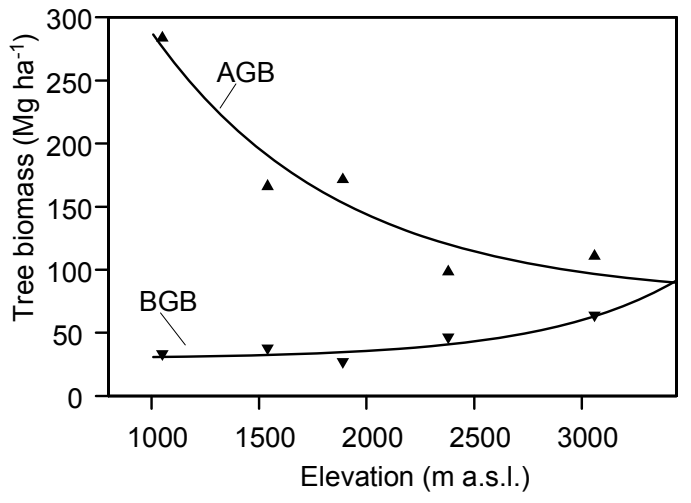

Figure 3.1: Stand above- and belowground biomass along the elevation transect in Ecuador. Aboveground biomass (AGB) was derived from tree height, $\mathrm{DBH}$ (each $\mathrm{n}=80$ ) and wood density data $(n=20)$ using the allometric equation of Chave et al. (2005) (see text). Belowground biomass (BGB) is the sum of coarse root biomass (diameter $>2$ $\mathrm{mm}, \mathrm{n}=12 / 16$ ) and fine root biomass (diameter $<2 \mathrm{~mm}, \mathrm{n}=15$ ). Details on regression analysis see Table 3.3.

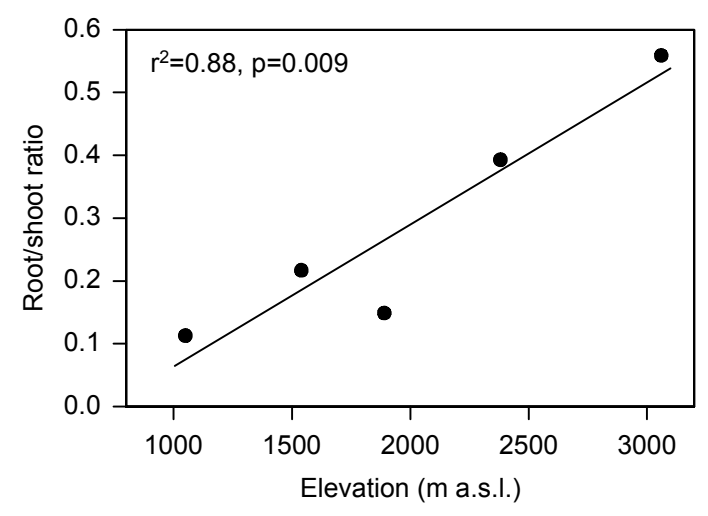

Fig. 3.2: Linear regression analysis between the root/shoot biomass ratio, calculated as the quotient of belowground biomass (BGB) to aboveground biomass (AGB), and elevation. 
all tested site factors, with closest relationship to the $\mathrm{C} / \mathrm{N}$ ratio of the organic layer, air temperature and elevation (Tab.3.3).

\subsubsection{Altitudinal TRENDS IN FOREST STRUCTURE, AND ABOVE- AND BELOWGROUND BIOMASS OF NEOTROPICAL MOIST FORESTS - A META-ANALYSIS}

Table 3.5 contains the results of correlation analyses between elevation and aboveand belowground forest biomass and various stand structural parameters based on data from up to 223 different stands. While only few data points from lowland forest were found for mean tree height, a high number of studies in montane forests included this parameter (Fig.3.3). The negative trend of mean tree height with increasing elevation was highly significant, even though the variation of documented mean tree height for a given elevation was rather high among the different stands. For example, mean tree height varied between 6 and $23 \mathrm{~m}$ at 2200 to $2400 \mathrm{~m}$ elevation. Elevation could explain $31 \%$ of the observed variability in tree height in this data set.

Table 3.5: Meta-analysis of the elevation-dependence of forest structure and biomass.

\begin{tabular}{|c|c|c|c|c|c|c|}
\hline Parameter & Source & $\mathbf{n}$ & Regression equation & $r^{2}$ & $r_{\text {adj }}^{2}$ & p \\
\hline Mean tree height & Elevation & 58 & $y=19.1-0.004 \cdot x$ & 0.31 & 0.30 & $<0.001$ \\
\hline Mean DBH & Elevation & 67 & $y=20.1-0.004 \cdot x$ & 0.31 & 0.30 & $<0.001$ \\
\hline Stem density & Elevation & 223 & $y=654.8+0.889 \cdot x$ & 0.46 & 0.46 & $<0.001$ \\
\hline Basal area & Elevation & 150 & $y=28.4+0.003 x$ & 0.13 & 0.12 & $<0.001$ \\
\hline AGB & Elevation & 92 & $y=298.7-0.039 \cdot x$ & 0.11 & 0.10 & 0.001 \\
\hline BGB & Elevation & 16 & $y=33.6+0.008 \cdot x$ & 0.15 & 0.09 & 0.068 \\
\hline Root / shoot ratio & Elevation & 16 & $y=0.112+8.142 \cdot 10^{-5} x$ & 0.30 & 0.25 & 0.013 \\
\hline
\end{tabular}

The altitudinal dependence of four structural parameters, and above- (AGB) and belowground biomass (BGB), and the root/shoot biomass ratio according to 65 studies with 266 stands from the Neotropics. $r^{2}$ and adjusted $r^{2}$ refer to linear or simple non-linear regression models. Relationships with $\mathrm{p}<0.05$ are printed in bold. Tree height is given in $\mathrm{m}, \mathrm{DBH}$ in $\mathrm{cm}$, stem density in ha $\mathrm{h}^{-1}$, basal area in $\mathrm{m}^{2} \mathrm{ha}^{-1}$ and above- and belowground biomass in $\mathrm{Mg} \mathrm{ha}^{-1}$. For data base see Appendix, List II.

The compiled data of mean DBH in neotropical forest stands correlate negatively with elevation. As in tree height, $31 \%$ of the variability of DBH was explained by elevation. Stem density was the stand structural parameter with the largest data base $(n=223)$. It showed a highly significant increase with altitude and showed the strongest dependence on elevation of all investigated parameters $\left(r^{2}=0.46\right)$.

Basal area is a parameter which showed a very large between-stand variation at higher elevations but rather uniform values between 20 and $40 \mathrm{~m}^{2} \mathrm{ha}^{-1}$ in lowland forests ( $<500 \mathrm{~m}$, Fig.3.4). For example, at an elevation of about $2300 \mathrm{~m}$, only $9.1 \mathrm{~m}^{2}$ $\mathrm{ha}^{-1}$ of basal area occurred in the Reserva Biologica San Francisco in South Ecuador (Homeier 2004), whereas $85.7 \mathrm{~m}^{2} \mathrm{ha}^{-1}$ were reached in a Venezuelan stand at this elevation (Cuello 2002). Despite this large variation, a significant increase of basal area with elevation appears from this data set (Tab.3.5). However, factors other than elevation must have a higher influence on the basal area of tropical forests. 


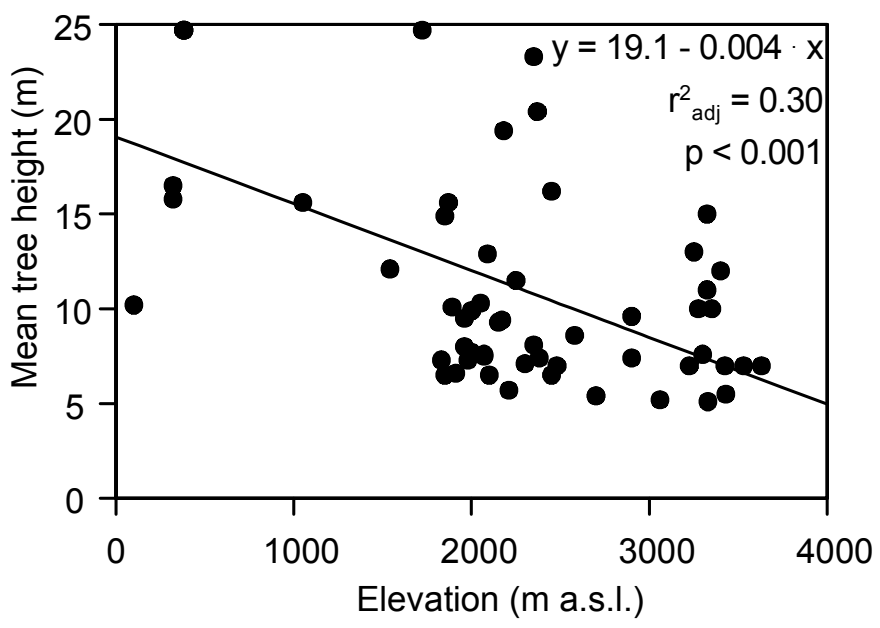

Figure 3.3: Relationship between elevation and mean tree height for 58 Neotropical moist forests. For more information on the regression analysis see Tab.3.5.

The large majority of aboveground biomass data relate to lowland forests. Only few studies from tropical montane forests exist to be compared with the aboveground biomass data of our Ecuadorian high Andean forests. Accordingly, the variability of AGB in lowland forests is very high with values ranging from 110 to $540 \mathrm{Mg} \mathrm{ha}^{-1}$ (Fig.3.5). AGB decreased significantly with elevation but the relative influence of altitude was low $\left(\mathrm{r}^{2}=0.11\right)$. The aboveground biomass of Venezuelan montane forests (Brun 1976, Steinhardt 1978, Grimm \& Fassbender 1981) was about twice as high as in our Ecuadorian montane stands.

Belowground biomass data were recorded only from 16 forest stands indicating a tendency for an increase with elevation. However, this relationship was only significant at $\mathrm{p}=0.07$ (Fig.3.6). Root/shoot ratio increased significantly with elevation (Fig.3.7, $\mathrm{p}=0.01$ ) with $25 \%$ of the variation explained by elevation (Tab.3.5).

\subsection{DisCUSSION}

\subsubsection{ALTITUDINAL CHANGE OF STAND STRUCTURE}

A consistent pattern of structural changes with increasing elevation can be observed: The tree height or stem length, DBH and leaf area index data show a general decrease with elevation, whereas stem density increases with altitude. In the large-scale altitudinal transects in Malaysia (Aiba and Kitayama 1999), Costa Rica (Lieberman et al. 1996) and Hawaii (Raich et al. 1997), and our meta-analysis tree height showed a more or less continuous decrease with altitude as it did in our Ecuadorian transect. Similarly, a continuous decrease of tree height from the lowlands to the timberline was also reported for undisturbed temperate mountain forests, e.g., in the Southern Alps of Italy (Reisigl \& Keller 1999) and in Tierra del Fuego (Pollmann and Hildebrand 2005). However, in certain mountain transects as on Tenerife, tree height seems to decrease upslope only slightly; the timberline may then consist of tall trees (Srutek et al. 2002). We speculate that a more or less continuous decrease in tree height occurs on mountain slopes where the altitudinal temperature decrease is the main environmental factor that controls tree growth and microbial activity in the soil. However, in all those mountains, where additional environmental constraints such 


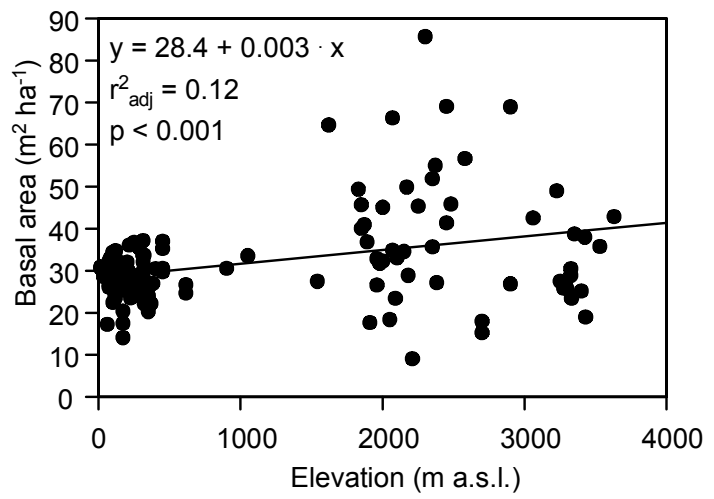

Figure 3.4: Relationship between stand basal area and elevation for 150 Neotropical moist forests (see also Tab.3.5).

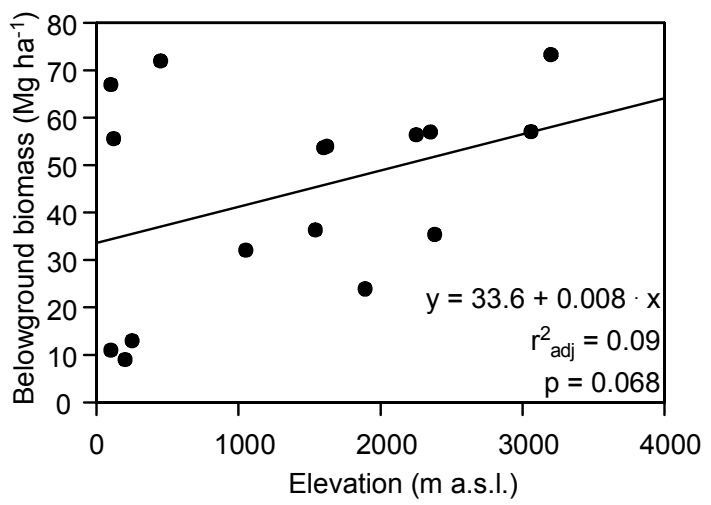

Figure 3.6: Relationship between belowground biomass and elevation for 16 Neotropical moist forests (see also Tab.3.5).

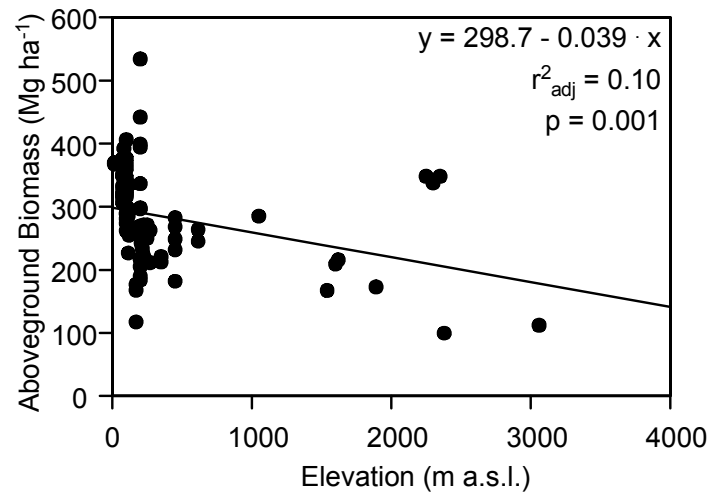

Figure 3.5: Relationship between aboveground biomass and elevation for 92 Neotropical moist forests (see also Tab.3.5).

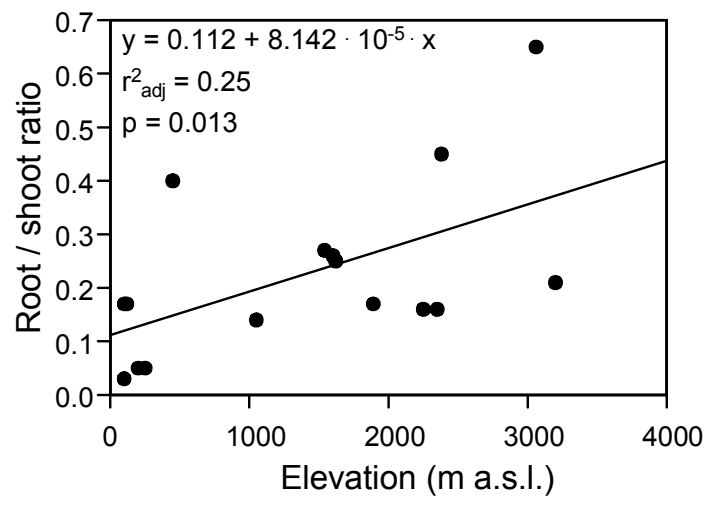

Figure 3.7: Relationship between root/shoot biomass ratio and elevation for 16 Neotropical moist forests (see Tab.3.5).

as water logging, drought or strong winds are influencing tree growth, these factors may overlay the temperature effect causing a more or less abrupt transition between tall high-elevation trees and low-statured krummholz or alpine non-forest vegetation higher upslope. An important second cause of abrupt timberlines is human impact that has lowered timberline elevation in many mountains of the tropics.

Altitudinal comparisons of mean DBH are often problematic because authors tend to define lower stem diameter limits at higher elevation where thinner stems prevail than in low-elevation forests with thicker stems, but even our meta-analysis revealed significant influence on DBH. If the lower DBH limit varies along the slope, a larger altitudinal decrease in mean DBH could be detected than exists in reality. Liebermann et al. (1996) fixed a DBH minimum in their Costa Rican elevation gradient between 100 and $2600 \mathrm{~m}$ of $10 \mathrm{~cm}$ and did not find altitudinal dependence but found highest means at high elevations. To avoid such a bias in the Ecuadorian transect we have investigated all stems that reach the canopy, irrespective of diameter. We found a 
decrease in mean DBH by a factor of 2.5 between stand \#1 and \#5 which is roughly proportional to the reduction in mean stem length from 15.6 to $5.2 \mathrm{~m}$.

Smaller trees with thinner stems and less extended crowns allow for higher tree densities per ground area when moving upslope in mountains. Altitudinal increases in tree density were not only reported for South Ecuador, but also for a transect on Mt. Kinabalu in Malaysia (Takyu et al. 2002) and the meta-analysis approves this trend. In contrast, Heaney \& Proctor (1990) found only minor changes in stem density between 100 and $2600 \mathrm{~m}$ on Volcan Barva, Costa Rica, probably because they used also a minimum DBH of $10 \mathrm{~cm}$ for their inventories at all elevations. Similarly, upper-montane Quercus forests in the Sierra de Talamanca (Costa Rica) at $2900 \mathrm{~m}$ a.s.l. had exceptionally low stem densities when only stems with a DBH greater 10 $\mathrm{cm}$ were considered $\left(390 \mathrm{ha}^{-1}\right)$. These values are not higher than in many tropical lowland forests. However, if all stems $>3 \mathrm{~cm} \mathrm{DBH}$ are included, stem density increases by a factor of nearly ten (3460 ha ${ }^{-1}$; Köhler 2002). On subtropical Mt. Teide, Tenerife, the density of Pinus canariensis trees remains constant with elevation or decreases (Srutek et al. 2002). We conclude that changes in tree density along tropical mountain slopes seem to be highly dependent on the floristic composition and the stand dynamics of the respective forest communities. In addition, tree density in highelevation forests may also depend on local edaphic and climatic conditions such as the occurrence of water logging or exposure to strong winds. Temporarily waterlogged soils favor woody plants that are able to resprout and to form multiple stems giving them a high morphological plasticity. For example, the widespread species Weinmannia loxensis (Cunoniaceae) in the uppermost stand (\#5 at $3060 \mathrm{~m}$ ) of the Ecuador transect forms creeping belowground stems which connect up to three shoots (Soethe et al. 2006). The ability of many tree species to grow multiple stems on temporarily waterlogged soils partly explains the very high stem densities that were counted in stand \#5 $\left(8317 \mathrm{ha}^{-1}\right)$.

The values of Madsen \& Øllgard (1994) (2568 and $3583 \mathrm{ha}^{-1}$ ) from upper montane forests of this region ( 2700 and $2900 \mathrm{~m}$ elevation) are lower than this value but they also indicate high tree densities close to the timberline.

Stand basal area is a function of mean DBH and stem density which both showed opposite trends with elevation in South Ecuador. In this transect, we found no clear altitudinal dependence of basal area although the highest value was measured at the uppermost stand. This is in line with results obtained by Lieberman et al. (1996) in Costa Rica. These results together with literature data indicate that basal area of tropical mountain forests seems to be only weakly dependent on climatic, edaphic or stand structural parameters such as maximum tree height (Aiba \& Kitayama 1999).

In Ecuador, leaf area index decreased continuously with elevation, as was found in the transect on Mt. Kinabalu (Kitayama \& Aiba 2002). This implies a decrease in canopy carbon gain with increasing elevation in the Ecuador transect, because neither leaf area-related foliar $\mathrm{N}$ content nor solar radiation changed significantly between 1000 and $3000 \mathrm{~m}$ elevation (M. Unger, pers. commun.). Carbon gain of forest canopies is mainly controlled by three factors, leaf photosynthetic capacity, which is linked to foliar $\mathrm{N}$ content, photosynthetic photon flux densities, and leaf area index. Therefore, assimilate availability should have decreased upslope along the transect, thus being one of the factors reducing tree height and aboveground biomass of highelevation forests in South Ecuador. 


\subsubsection{ALTITUDINAL CHANGE OF TREE BIOMASS AND ROOT/SHOOT RATIO}

Total aboveground tree biomasses significantly decreased with altitude in the Ecuadorian transect. Temperature and $\mathrm{C} / \mathrm{N}$ ratio of the organic layer are variables that also showed a similarly close relation to AGB as did elevation because both are strongly correlated with elevation. A causal explanation of the reduction in AGB must remain speculative since elevation, temperature, soil $\mathrm{C} / \mathrm{N}$ ratio and also soil $\mathrm{pH}$ are closely related to each other in the Ecuadorian transect. Specific hypotheses require experimental testing.

A striking result of this study is the high fine and coarse root biomass of the highelevation forests in Ecuador. Belowground biomass (BGB) of the uppermost stand (\#5 at $3060 \mathrm{~m}$ ) was about two times greater than that of the stands \#1 to 3 (1050 to $1890 \mathrm{~m}$ ). Corresponding trends in fine root biomass with elevation have been reported by Kitayama \& Aiba (2002) on Mt. Kinabalu, and in our meta-analysis and a more comprehensive one on fine root data of paleo- and neotropical forests by Hertel \& Leuschner (2006). Thus, a direct effect of lowered temperature on aboveground meristematic activity and tree growth is unlikely because air and soil temperature differed by not more than $1{ }^{\circ} \mathrm{C}$ from each other, and branch and root meristems should have responded similarly to a reduction in temperature along the slope. Rather, a direct or indirect effect of lowered temperature on carbon allocation patterns of the trees must play a prominent role for the altitudinal reduction in AGB.

A fivefold increase in the root/shoot ratio of the trees between 1050 and $3060 \mathrm{~m}$ in the Ecuador transect underlines the large carbon allocation shift from aboveground to belowground tree organs that takes place along this slope approved by the neotropical meta-analysis.

\subsection{CONCLUSIONS}

According to the resource balance hypothesis of Bloom et al. (1985) the impressive change in allocation patterns is best explained by a growing importance of limiting soil resources over limiting light with increasing elevation. Increasing carbon and nutrient allocation to roots on the cost of aboveground biomass would then represent a compensatory response of the trees to cope with an increasing limitation by nutrient and/or water shortage at high elevations.

Water shortage is unlikely to occur at the high-elevation sites in South Ecuador; rather, water logging may have contributed to a slowing down of decomposition and thus a poor nutrient supply in the uppermost stands (Schuur 2001). There are several possible pathways by which low temperatures may have resulted in impaired nutrient supply or uptake, among them: (a) a reduction in decomposition rate, (b) a low activity of mycorrhizal fungi and (c) a reduction in membrane transporter activity and thus a lowered nutrient uptake rate.

Unfavorable soil chemical conditions as a consequence of low nutrient contents in plant litter, or high concentration of free aluminum and elevated $\mathrm{Al} / \mathrm{Ca}$ ratios in the soil solution (Hafkenscheid 2000) may also negatively affect root vitality and root growth, additionally impairing nutrient uptake. Finally, the observed large stocks of coarse root biomass in the uppermost stands, which mainly serve for tree anchoring, point at the growing need for tree stabilization on steep and wet slopes at high elevations (Soethe et al. 2006). 
While it is unlikely that a single factor is responsible for the observed remarkable carbon allocation shift with increasing elevation, there is an urgent need of well designed field experiments aimed at disentangling the possible influencing factors that may limit nutrient supply and nutrient uptake in these high-elevation tropical forests.

\subsection{ACKNOWLEDGEMENTS}

We are grateful to J. Homeier (University of Göttingen) who provided floristic inventory data for the five Ecuadorian stands. We also thank S. Iost and F. Makeschin (Technical University of Dresden) for contributing the $\mathrm{pH}$ and $\mathrm{C} / \mathrm{N}$ ratio data and information on soil types, P. Emck and M. Richter (University of Erlangen) for supplying the rainfall data, and M. Unger (University of Göttingen) for leaf chemical and radiation data. For technical support with the LAI-2000 measurements we thank M. Küppers (University of Hohenheim).

\subsection{REFERENCES}

Aiba, S., Kitayama, K. 1999. Structure, composition and species diversity in an altitude-substrate matrix of rain forest tree communities on Mount Kinabalu, Borneo. Plant Ecology 140: 139-157.

Balslev, H., Øllgaard, B. 2002. Mapa de vegetación del sur de Ecuador. In: Aguirre, Z.M., Madsen, J.E., Cotton, E., Balslev H. (eds.). Botánica Austroecuatoriana Estudios sobre los recursos vegetales en las provincias de el Oro, Loja y ZamoraChinchipe, Ediciones ABYA YALA, Quito, pp. 51-64.

Beck, E., Makeschin, F., Haubrich, F., Richter, M., Bendix, J. 2008. The Ecosystem (Reserva Biológica San Francisco). In: Beck, E., Bendix, J., Kottke, I., Makeschin F., Mosandl, R. (eds.). Gradients in a tropical mountain ecosystem of Ecuador. Ecological Studies, Vol. 198, Springer Verlag, Berlin, Heidelberg, in press.

Bendix, J., Rollenbeck, R., Richter, M., Fabian, P., Emck, P. 2008. Gradual changes along the altitudinal gradient: climate. In: Beck, E., Bendix, J., Kottke, I., Makeschin F., Mosandl, R. (eds.). Gradients in a tropical mountain ecosystem of Ecuador. Ecological Studies, Vol. 198, Springer Verlag, Berlin, Heidelberg, in press.

Bloom, A.J., Chapin III, F.S., Mooney, H.A. 1985. Resource limitation in plants - an economic analogy. Annual Review of Ecology and Systematics 16: 363-392.

Brown, S., Iverson, L.R. 1992. Biomass estimates for tropical forests. World Resource Review 4: 366-384.

Brown, S. 1997. Estimating biomass and biomass change of tropical forests: a primer. FAO Forestry Paper 134.

Bruijnzeel, I.A., Procter, J. 1995. Hydrology and biogeochemistry of tropical montane cloud forest: what do we really know? In: Lawrence, H.S., Juvrik, J.O., Scatena, F.N. (eds.). Tropical montane cloud forests. Springer, New York, Ecological Studies 110: 38-78. 
Brun, R. 1976. Methodik und Ergebnisse zur Biomassenbestimmung eines Nebelwald-Ökosystems in den Venezolanischen Anden. Proc. 16th IUFRO World Congress, Div. I, Norway, pp. 490-499.

Chave, J., Condit, R., Aguilar, S., Hernandez, A., Lao, S., Perez, R. 2004. Error propagation and scaling for tropical forest biomass estimates. Philosophical Transaction of the Royal Society London, B 359: 409-420.

Chave, J., Andalo, C., Brown, S., Cairns, M.A., Chambers, J.Q., Eamus, D., Folster, H., Fromard, F., Higuchi, N., Kira, T., Lescure, J.P., Nelson, B.W., Ogawa, H., Puig, H., Riera, B., Yamakura, T. 2005. Tree allometry and improved estimation of carbon stocks and balance in tropical forests. Oecologia 145: 87-99.

Cuello, N.L. 2002. Altitudinal changes of forest diversity and composition in the Ramal de Guaramacal in the Venezuelan Andes. Ecotropicos 15: 160-176.

Flenley, J.R. 1995. Cloud forest, the Massenerhebung effect, and ultraviolet insolation. In: Hamilton, L.S., Juvrik, J.O., Scatena, F.N. (eds.). Tropical montane cloud forests. Springer, New York. Ecological Studies 110, pp 150-155.

Gentry, A.H., Lötscher, H., Oeschger, H., Seigenthaler, U., Stuffer, B. 1995. Patterns of diversity and floristic composition in neotropical montane forests. In: Churchill, S.P. (ed). Biodiversity and conservation of neotropical montane forests, New York Botanical Garden, The Bronx, USA, pp. 103-126.

Gerwing, J.J., Schnitzer, S.A., Burnham, R.J., Bongers, F., Chave, J., DeWalt, S.J., Ewango, C.E.N., Foster, R., Kenfack, D., Martinez-Ramos, M., Parren, M., Parthasarathy, N., Perez-Salicrup, D.R., Putz, F.E. \& Thomas, D.W. 2006. A standard protocol for liana censuses. Biotropica, 38: 256-261.

Grimm, U., Fassbender, H.W. 1981. Ciclos bioquímicos en un ecosistema forestal de los Andes Occidentales de Venezuela. I. Inventario de las reservas orgánicas y minerales (N, P, K, Ca, Mg, Mn, Fe, Al, Na). Turrialba 31(1): 27-37.

Hafkenscheid, R.L.L.J. 2000. Hydrology and biogeochemistry of tropical montane rain forests of contrasting stature in the Blue Mountains, Jamaica. Dissertation, University of Amsterdam, The Netherlands, pp. 302.

Heaney, A., Procter, J. 1990. Preliminary studies on forest structure and floristics on Volcán Barva, Costa Rica. Journal of Tropical Ecology 6: 307-320.

Hertel, D., Leuschner, Ch. 2007. Fine root mass and fine root production in tropical moist forests as dependent on soil, climate and elevation. In: Bruijnzeel, L.E., Juvik, J.O. (eds.). Mountains in the mist: science for conserving and managing tropical montane cloud forests, Hawaii Uni Press, in press.

Homeier, J. 2004. Baumdiversität, Waldstruktur und Wachstumsdynamik zweier tropischer Bergregenwälder in Ecuador und Costa Rica. Dissertationes Botanicae 391, pp. 207.

Iost, S., Makeschin, F., Abiy, M., Haubrich, F. 2008. Biotic soil activities. In: Beck, E., Bendix, J., Kottke, I., Makeschin F., Mosandl, R. (eds.). Gradients in a tropical mountain ecosystem of Ecuador. Springer, Berlin, Heidelberg, Ecological Studies 198, in press.

Kessler, M. 2000. Elevational gradients in species richness and endemism of selected plant groups in the central Bolivian Andes. Plant Ecology 149: 181-193.

Kessler, M. 2001. Patterns of diversity and range size of selected plant groups along an elevational transect in the Bolivian Andes. Biodiversity and Conservation 10: 1897-1921. 
Kitayama, K., Aiba, S.-I. 2002. Ecosystem structure and productivity of tropical rain forests along altitudinal gradients with contrasting soil phosphorus pools on Mount Kinabalu, Borneo. Journal of Ecology 90: 37-51.

Köhler, L. 2002. Die Bedeutung der Epiphyten im ökosystemaren Wasser- und Nährstoffumsatz verschiedener Altersstadien eines Bergregenwaldes in Costa Rica. Dissertation University Göttingen, Berichte des Forschungszentrums Waldökosysteme, Reihe A, Bd. 181, pp. 134.

Leuschner, Ch., Hertel, D., Coners, H., Büttner, V. 2001. Root competition between beech and oak: a hypothesis. Oecologia 126: 276-284.

Lieberman, D., Lieberman, M., Peralta, R., Hartshorn, G.S. 1996. Tropical forest structure and composition on a large-scale altitudinal gradient in Costa Rica. Journal of Ecology 84: 137-152.

Madsen, J.E., Øllgaard, B. 1994. Floristic composition, structure, and dynamics of an upper montane rain-forest in Southern Ecuador. Nordic Journal of Botany 14: 403-423.

Nadkarni, N.M., Matelson, T.J., Haber, W.A. 1995. Structural characteristics and floristic composition of a neotropical cloud forest, Monteverde, Costa Rica. Journal of Tropical Ecology 11: 481-495.

Pollmann, W., Hildebrand, R. 2005. Structure and the composition of species in timberline ecotones of the Southern Andes. In: Broll, G., Keplin, B. (eds.). Mountain ecosystems - studies in treeline ecology, Springer, Berlin, pp. 117-151.

Raich, J.W., Russell, A.E., Vitousek, P.M. 1997. Primary productivity and ecosystem development along an elevational gradient on Mauna Loa, Hawai'i. Ecology 78: 707-721.

Reisigl, H., Keller, R. 1999. Lebensraum Bergwald. Spektrum Akademie Verlag, Heidelberg, $147 \mathrm{pp}$.

Schnitzer, S.A., DeWalt, S.J. \& Chave, J. 2006. Censusing and measuring lianas: A quantitative comparison of the common methods. Biotropica 38: 581-591.

Schuur, E.A.G. 2001. The effect of water on decomposition dynamics in mesic to wet Hawaiian montane forests. Ecosystems 4: 259-273.

Soethe, N., Lehmann, J., Engels, C. 2006. Root morphology and anchorage of six native tree species from a tropical montane forest and an elfin forest in Ecuador. Plant and Soil 279: 173-185.

Srutek, M., Dolezal, J., Hara, T. 2002. Spatial structure and associations in a Pinus canariensis population at the treeline, Pico del Teide, Tenerife, Canary Islands. Arctic, Antarctic and Alpine Research 34: 201-210.

Steinhardt, U. 1978. Untersuchungen über den Wasser- und Nährstoffhaushalt eines andinen Wolkenwaldes in Venezuela. Dissertation, University Göttingen, Germany, pp. 182.

Takyu, M., Aiba, S.-I., Kitayama, K. 2002. Effects of topography on tropical lower montane forests under different geological conditions on Mount Kinabalu, Borneo. Plant Ecology 159: 35-49.

Tanner, E.V.J. 1980. Studies on the biomass and productivity in a series of montane rain forests in Jamaica. Journal of Ecology 68: 573-588.

Wattenberg, I., Breckle, S.-W. 1995. Tree species diversity of a premontane rain forest in the Cordillera de Tilarán, Costa Rica. Ecotropica 1: 21-30.

Weaver, P.L., Murphy, P.G. 1990. Forest structure and productivity in Puerto-Rico Luquillo Mountains. Biotropica 22: 69-82. 
Wilcke, W., Yasin, S., Schmitt, A., Valarezo, C., Zech, W. 2008. Soils. In: Beck, E., Bendix, J., Kottke, I., Makeschin F., Mosandl, R. (eds.). Gradients in a tropical mountain ecosystem of Ecuador. Springer Verlag, Berlin, Heidelberg, Ecological Studies 198, in press.

Yamakura, T., Hagihara, A., Sukardjo, S., Ogawa, H. 1986. Aboveground biomass of tropical rain-forest stands in Indonesian Borneo. Vegetatio 68: 71-82.

Young, K.R. 1998. Composition and structure of a timberline forest in North-Central Peru. In: Dallmeier, F., Comiskey, J.A. (eds.). Man and the biosphere series 21, Paris, UNESCO, pp. 595-613. 


\section{LARGE ALTITUDINAL INCREASE IN TREE ROOT/SHOOT RATIO IN TROPICAL MOUNTAIN FORESTS OF ECUADOR*}

\subsection{SUMMARY}

Tropical rain forests decrease in tree height and aboveground biomass (AGB) with increasing elevation. The causes of this phenomenon remain insufficiently understood despite a number of explanations proposed including direct or indirect effects of low temperature on carbon acquisition and carbon investment, adverse soil conditions and impaired nutrient supply. For analysing altitudinal patterns of aboveground/belowground carbon partitioning, we measured fine $(<2 \mathrm{~mm}$ in diameter) and coarse root $(2-5 \mathrm{~mm})$ biomass and necromass and leaf area index (LAI), and estimated AGB from stand structural parameters in five tropical mountain rain forests at 1050, 1540, 1890, 2380 and $3060 \mathrm{~m}$ along an altitudinal transect in the South Ecuadorian Andes. Average tree height and AGB were reduced to less than $50 \%$ between 1050 and 3060 m, LAI decreased from 5.1 to 2.9. The leaf area reduction must have resulted in a lowered canopy carbon gain and thus may partly explain the reduced tree growth in the high-elevation stands. In contrast, both fine and coarse root biomass significantly increased with elevation across this transect. The ratio of root biomass (fine and coarse) to AGB increased more than ten-fold from 0.04 at $1050 \mathrm{~m}$ to 0.43 at $3060 \mathrm{~m}$. Under the assumption that fine root biomass does reflect root productivity, our data indicate a marked belowground shift in $\mathrm{C}$ allocation with increasing elevation. Possible explanations for this allocation shift are discussed including reduced $\mathrm{N}$ supply due to low temperatures, water logging or adverse soil chemical conditions. We conclude that the fine root system and its activity may hold the key for understanding the impressive reduction in tree size along tropical mountain slopes in Ecuador. Analyses of fine root turnover and longevity in relation to environmental factors along altitudinal transects in tropical mountains are urgently needed.

4.2 KEYWORDS: Aboveground biomass, carbon partitioning, fine root biomass, fine root necromass, nutrient limitation, root/shoot ratio.

\footnotetext{
*published in: Basic and Applied Ecology 8: Ch. Leuschner, G. Moser, C. Bertsch, M. Röderstein, D. Hertel 2007. Large altitudinal increase in tree root/shoot ratio in tropical mountain forests of Ecuador. Pp. 219-230. With kind permision from Elsevier, (C) 2006 Gesellschaft für Ökologie.
} 


\subsection{INTRODUCTION}

Perhaps the most obvious change that occurs with elevation on tropical mountains is a gradual decrease in tree height (Whitmore 1998). In equatorial regions, tropical lowland forest is replaced by Lower Montane Forest (LMF) typically at about 1000-1200 m a.s.1. which gives way to Upper Montane Forest (UMF) at about 1800-2200 m. LMF trees reach a maximum height of 25-35 $\mathrm{m}$ (at the most $40 \mathrm{~m}$ ), whereas UMF trees grow not taller than 18-22 $\mathrm{m}$ and decrease in height from their lower limit toward the tree line where less than $10 \mathrm{~m}$ are reached. Elfin forests with trees 3-7 m tall are common immediately below the tree line in many high equatorial mountains. Average leaf size and specific leaf area decrease with elevation as well (Ashton 2003).

For several decades, there has been an intensive debate among plant ecologists on the causes of this altitudinal reduction in tree size in tropical mountains. A number of explanations for reduced growth in tropical high-elevation forests has been suggested including reduced plant surface temperatures due to dense cloud cover (Grubb 1977), periodic drought stress on shallow mountain soils (van Steenis 1972), limited oxygen supply in water-logged soils (Hetsch \& Hoheisel 1976), low nutrient supply (Tanner et al. 1998), limited nutrient uptake due to diminished transpiration, high concentrations of phenolic compounds and/or free aluminium in soil organic matter (Bruijnzeel \& Proctor 1995, Bruijnzeel \& Veneklaas 1998, Hafkenscheid 2000), strong winds (Sugden 1986), or elevated UV-B radiation and damage of the photosynthetic apparatus at high elevation (Flenley 1996). An alternative hypothesis is that the altitudinal decrease in tree height in tropical mountains is primarily the consequence of a shift in aboveground/belowground carbon allocation patterns, whereas sink or source limitation of carbon turnover are of only secondary importance. There are recent observations showing a much larger fine root biomass (FRB) in tropical mountain forests than in lowland forests (Cairns et al. 1997, Hertel et al. 2003, Kitayama \& Aiba 2002, Vogt et al. 1996). However, sound conclusions on altitudinal trends in tree root biomass of tropical mountain forests cannot be drawn because the data is very limited. Moreover, the underlying causes of putative allocation shifts remain unclear.

In a 2000-m altitudinal transect in the South Ecuadorian Andes with five forest stands selected at 1050, 1540, 1890, 2380 and $3060 \mathrm{~m}$ a.s.1., we investigated fine and coarse root biomass and estimated aboveground biomass (AGB). The main objective of the present study is to analyse altitudinal changes in tree belowground/aboveground biomass partitioning and to relate altitudinal trends in the tree root/shoot ratio to changes in temperature and soil chemical variables along the slope.

\subsection{MethodS}

\subsubsection{STUDY SITES}

Five mountain forest stands in the South Ecuadorian province of Zamora-Chinchipe on the eastern slopes of the Andes were selected for comparative study. The study area is one of the remaining regions in the Northern Andes with only low human impact on forest vegetation in a broad altitudinal zone. Stand selection was based on the following attributes: (a) no visible disturbance by humans or landslides, (b) more or less closed canopies without major treefall gaps, (c) structural homogeneity in an area of at least $100 \mathrm{~m} \times 100 \mathrm{~m}$, and (d) position on moderately steep slopes $\left(10-30^{\circ}\right)$ in a more or less smooth terrain, thus avoiding hollows and ridges. The study plots were selected in appropriate forest sections that fulfilled the above criteria.

The five stands are located on the northern slopes of the Podocarpus National Park between Loja and Zamora (S031580-04160, W781580-791100) at a maximum distance to 
each other of $50 \mathrm{~km}$. With elevations of 1050, 1540, 1890, 2380 and $3060 \mathrm{~m}$ a.s.1., an altitudinal gradient of $2000 \mathrm{~m}$ was covered. Stands 1 and $2(1050$ and $1540 \mathrm{~m})$ are $10 \mathrm{~km}$ south of Zamora upslope of the village of Bombuscaro, stand $3(1890 \mathrm{~m})$ is in close vicinity of Estación Científica San Francisco (ECSF) south of the road from Loja to Zamora. Stand $4(2380 \mathrm{~m})$ is located $400 \mathrm{~m}$ upslope of ECSF, stand $5(3060 \mathrm{~m})$ in the Cajanuma area at the northwestern gate of the National Park about $20 \mathrm{~km}$ south of Loja. The stands are situated on slopes facing east to northwest.

While the lowermost stand $(1050 \mathrm{~m})$ is situated in the transition zone between tropical lowland and LMF, the stands 2, 3 and 4 are in the lower to upper montane belt (bosque siempreverde montano, Balslev \& Øllgaard 2002; bosque de neblina montano, Valencia et al. 1999). Stand $5(3060 \mathrm{~m})$ is situated close to the tree line which is found at $3300-3500 \mathrm{~m}$ in the Loja/Zamora region. This stand is a typical 'elfin forest' with stunted tree growth. Patches of alpine paramo are found about $200 \mathrm{~m}$ upslope of this site. The structure and floristics of the forests at the five sites are considerably different. However, the same plant life form (i.e. evergreen broad-leaved trees) occurs throughout. All forests are species-rich with about 100 tree species per 0.6 ha. Lauraceae, Melastomataceae and Rubiaceae are the most species-rich and most frequent tree families in the stands (Homeier 2004).

The soils have formed on acidic phyllite, sandstone or shale bedrocks with Alumic Acrisols being present at the two lower sites $(1050$ and $1540 \mathrm{~m})$ and Cambisols or Podzols found at the three upper ones (1890-3060 m). The organic layer atop of the mineral soil increases in thickness from about $50 \mathrm{~mm}$ at $1050 \mathrm{~m}$ to ca. $430 \mathrm{~mm}$ at $3060 \mathrm{~m}$ (Tab.4.1). There is a decrease in soil $\mathrm{pH}\left(\mathrm{H}_{2} \mathrm{O}\right)$ from 4.7 to 3.2 and an increase in $\mathrm{C} / \mathrm{N}$ ratio $(17-26)$

Table 4.1: Location and site characteristics of the five studied forest stands

\begin{tabular}{|c|c|c|c|c|c|}
\hline \multirow[b]{3}{*}{ Elevation (m a.s.l) } & \multicolumn{5}{|l|}{ Stand } \\
\hline & 1 & 2 & 3 & 4 & 5 \\
\hline & 1050 & 1540 & 1890 & 2380 & 3060 \\
\hline Slope $\left({ }^{\circ}\right)$ & 26 & 10 & 31 & 28 & 27 \\
\hline Mean air temperature ${ }^{a}\left({ }^{\circ} \mathrm{C}\right)$ & 18.9 & 16.7 & 14.9 & 12.3 & 8.6 \\
\hline Minimum air temperature ${ }^{\mathrm{a}}\left({ }^{\circ} \mathrm{C}\right)$ & 13.2 & 11.2 & 7.9 & 6.9 & 3.8 \\
\hline Mean soil temperature ${ }^{a}\left({ }^{\circ} \mathrm{C}\right)$ & 19.9 & 18.2 & 16.0 & 15.0 & 9.5 \\
\hline Mean air humidity ${ }^{a}(\%)$ & 96.1 & 92.7 & 93.7 & 95.4 & 94.3 \\
\hline Rainfall $\left(\mathrm{mm} \mathrm{yr} \mathrm{r}^{-1}\right)$ & ca. $2230^{a}$ & ca. $2300^{a}$ & ca. $1950^{b}$ & ca. $5000^{b}$ & ca. $4500^{b}$ \\
\hline Soil type & Alumic Acrisol & Alumic Acrisol & Gleyic Cambisol & Gleyic Cambisol & Podzol \\
\hline Organic layer thickness (mm) & 48 & 243 & 305 & 214 & 435 \\
\hline $\mathrm{pH}\left(\mathrm{H}_{2} \mathrm{O}\right)$ : mineral soil $(0-10 \mathrm{~cm})$ & 4.7 & 4.9 & 3.8 & 3.3 & 3.2 \\
\hline $\mathrm{C} / \mathrm{N}$ : organic layer $\mathrm{L} / \mathrm{Of}_{1}$ & 22 & 29 & 28 & 46 & 63 \\
\hline $\mathrm{C} / \mathrm{N}$ : organic layer $\mathrm{Of}_{2} / \mathrm{Oh}$ & 19 & 22 & 19 & 25 & 30 \\
\hline $\mathrm{C} / \mathrm{N}$ : mineral soil $(0-10 \mathrm{~cm})$ & 17 & 21 & 18 & 18 & 26 \\
\hline
\end{tabular}

Microclimatological data were recorded at $1.5 \mathrm{~m}$ height inside the stands. Rainfall data are extrapolated from gauges at 1050 (own measurement) 1950, 2680 and $2900 \mathrm{~m}$ (P. Emck, unpubl. data). Soil moisture was continuously recoded by TDR probes. $\mathrm{C} / \mathrm{N}$ data by $\mathrm{S}$. Iost and $\mathrm{F}$. Makeschin, $\mathrm{pH}$ data by N. Soethe (unpubl. data). Soil types according to FAO classification.

${ }^{\text {a}}$ Period March-August 2003.

${ }^{\text {b} P e r i o d ~ A u g u s t ~ 2001-F e b r u a r y ~} 2003$. 
along the slope (mineral topsoil: $0-10 \mathrm{~cm}$ ). Particularly large $\mathrm{C} / \mathrm{N}$ ratios $(46-63)$ were found in the uppermost organic horizons of the high elevation stands 4 and 5 (Tab.4.1, S. Iost, F. Makeschin, \& N. Soethe, unpubl. data). In general, the soils of the study region are of low fertility with small cation exchange capacities and low base saturations (Schrumpf et al. 2001).

The climate is characterised by $8-10$ humid months and a somewhat higher rainfall between April and July, and a drier period from October to February (P. Emck, University of Erlangen, unpubl. data). However, even the driest month (January) received $58 \mathrm{~mm}$ of rain in the 2001/2002 study period which is close to the threshold used to denote a dry month. Thus, extended periods of drought are unusual in the study region. According to three rain gauges in the upper slope section, annual rainfall increases with elevation from estimated $1950 \mathrm{~mm} \mathrm{yr}^{-1}$ at $1980 \mathrm{~m}^{2}$ about $5000 \mathrm{~mm} \mathrm{yr}^{-1}$ at $2380 \mathrm{~m}$ and ca. $4500 \mathrm{~mm} \mathrm{yr}^{-1}$ at $3060 \mathrm{~m}$ (P. Emck, unpubl. data). Rainfall data for the lower slope section were measured at $1050 \mathrm{~m}$. Mean air temperature as measured inside the forest $(1.5 \mathrm{~m}$ height $)$ decreased from $18.9^{\circ} \mathrm{C}(1050 \mathrm{~m})$ to $8.6^{\circ} \mathrm{C}(3060 \mathrm{~m})$ reflecting a temperature lapse rate of about 0.005 $\mathrm{K} \mathrm{m}^{-1}$ along the slope.

\subsubsection{INVENTORY OF ABOVEGROUND FOREST STRUCTURE AND BIOMASS ESTIMATION}

All five stands had closed canopies with no major gaps and showed no or only minimal signs of human influence. Plots of 0.16 ha $(40 \times 40 \mathrm{~m})$ were established in representative sections of the stands. Rectangular grids with a line distance of $4 \mathrm{~m}$ were demarcated for determining the exact position of the stems and for allowing random sampling of root biomass. In the plots, all trees $450 \mathrm{~mm}$ in diameter at breast height $(1.3 \mathrm{~m}, \mathrm{D})$, at least 80 stems per plot, were measured for diameter and height $(\mathrm{H})$ using a fabric diameter tape $(+1$ $\mathrm{mm}$ resolution) and an ultrasonic tree height meter (Vertex III Forester, Haglöf, Langsele, Sweden). A few trees had large buttresses that reached $1.3 \mathrm{~m}$ in height. In these cases, D was measured $0.2-0.7 \mathrm{~m}$ higher up the stem. We calculated the basal area for all stems 450 $\mathrm{mm}$ in the 0.16 ha plots and extrapolated the data to 1 ha. Tree population means of $\mathrm{D}$ and $\mathrm{H}$ were calculated for subsamples of 80 trees per plot. Stand level estimates of tree AGB were obtained with allometric regressions of $\mathrm{D}$, or $\mathrm{D}$ and $\mathrm{H}$, on biomass as suggested by Brown \& Iverson (1992) and Brown (1997; Tab.4.3). The two equations used were found to be applicable to tropical mountain forests (Brown 1997).

The leaf area index (LAI) of the stands was estimated by measurements with a LAI-2000 system (Li-Cor, Lincoln, NE, USA) conducted at each 10 randomly chosen positions per stand. Stand averages of specific leaf area (SLA) were obtained from leaf area and dry mass determinations in subsamples of 50 leaves per plot collected in the litter traps. Stand leaf biomass as calculated from the LAI and SLA data was then subtracted from the regressionbased AGB estimates, which include stem, branch and leaf biomass, to obtain aboveground wood biomass.

\subsubsection{ROOT SAMPLING AND ANALYSIS}

Soil coring was conducted from March to May 2003 in order to analyse fine root (diameter $<2 \mathrm{~mm}$ ) and coarse root (diameter 2-5 $\mathrm{mm}$ ) biomass (live roots) and necromass (dead roots) in soil profiles under the five stands. In a preliminary investigation, changes in root density with depth were analysed in cores to $60-80 \mathrm{~cm}$ in the mineral soil. By far the highest fine root densities occurred in the thick organic layers and in the uppermost horizons of the mineral soil whereas root densities in the subsoil were very low. We estimated that the organic layer and the mineral soil to $30 \mathrm{~cm}$ depth must contain about $75 \%$ or more of the profile total of tree FRB. Subsequently, profile totals of root biomass refer to the organic layer and the mineral soil to $30 \mathrm{~cm}$ depth. In the case of coarse roots, our profile 
totals may significantly underestimate the root biomass of the stand because this diameter class reached larger densities in the subsoil. We did not investigate large roots with diameters $45 \mathrm{~mm}$.

Root sampling was conducted with a steel corer (33 $\mathrm{mm}$ in diameter) at 20 randomly selected locations per plot. The cores were sliced into the organic layer and the mineral topsoil horizon $(0-10 \mathrm{~cm})$. In the lower part of the profile, samples were extracted at 10-20 and $20-30 \mathrm{~cm}$ depth $(\mathrm{n}=15)$. The soil material was placed into polyethylene bags and stored in the refrigerator $\left(4^{\circ} \mathrm{C}\right)$ of the laboratory at Estación Científica San Francisco where processing took place within 30 days.

In the laboratory, the samples were soaked in water and cleaned from soil residues using a sieve of $0.25 \mathrm{~mm}$ mesh size. The root material was sorted by diameter $(<2 \mathrm{~mm}, 2-5$ $\mathrm{mm},>5 \mathrm{~mm}$ ) into fine, coarse and large roots with the latter fraction being discarded. We considered only tree and tree fern roots but omitted roots of herbs, ground-living bromeliads and grasses. These plants with comparably fine branch roots contributed only a few percent to total FRB.

In all samples, large root fragments $(>10$ $\mathrm{mm}$ ) were extracted by hand. For investigating the small particles of FRB and fine root necromass (FRN) quantitatively, detailed analyses under the stereomicroscope were conducted in randomly selected subsamples. Ten of the 20 samples per plot were analysed in detail following a procedure described by van Praag et al. (1988) and modified by Hertel \& Leuschner (2002). After extracting the large root fragments manually, the residue of the sample was spread evenly on a piece of filter paper $\left(730 \mathrm{~cm}^{2}\right)$ with 36 squares marked on it. Six of the squares were randomly selected and analysed under the microscope for even the smallest live and dead fine root fragments. These small root particles consisted of fine root tips and small branch roots broken off during sampling, and of decaying root particles. The latter represent the main root necromass fraction (Bauhus \& Bartsch 1996, Hertel 1999). Live and dead rootlets were distinguished under the stereomicroscope by colour, root elasticity,

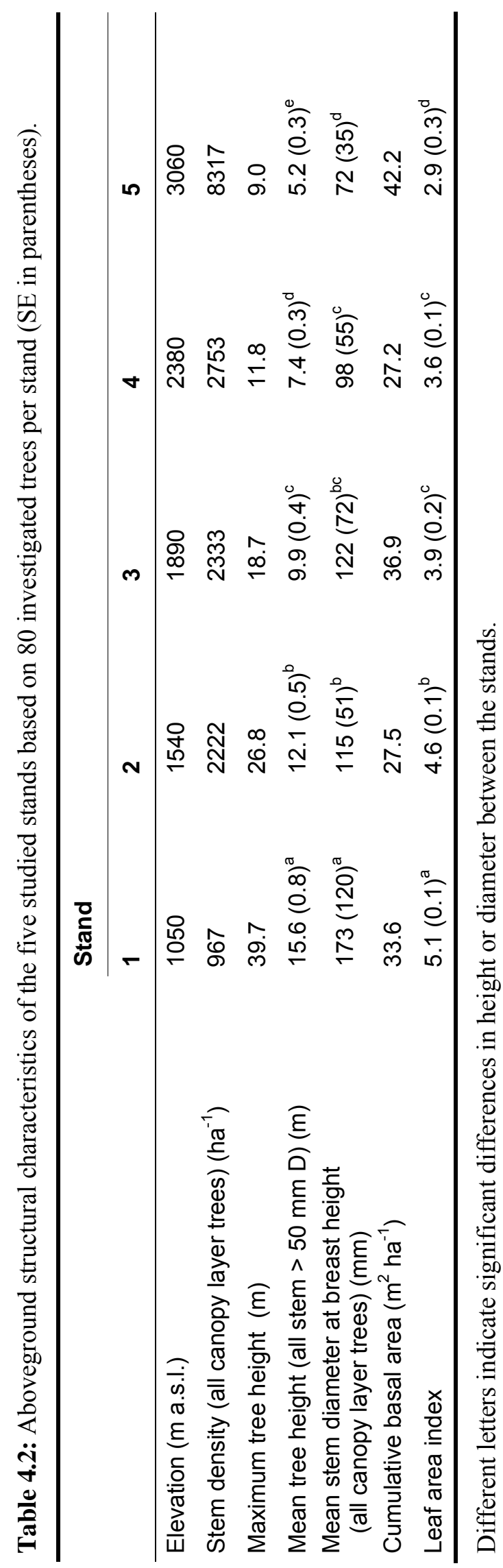


and the degree of cohesion of cortex, periderm and stele. A dark cortex and stele, or a white, but non-turgid cortex and stele, or the complete loss of the stele and cortex with only the periderm being present, were used as indicators of root death (Persson 1978). In an earlier investigation, we had validated these criteria for fine roots of temperate tree species with a TTC staining test after Knievel (1973).

The mass of small live and dead rootlets wase extrapolated to the entire sample by means of the ratio of small rootlets to large $(>10 \mathrm{~mm})$ manually extracted root fragments that was established in a subsample. Root biomass and necromass were dried at $70^{\circ} \mathrm{C}(48 \mathrm{~h})$ and weighed. Root masses are given as profile totals (organic layer plus $0-30 \mathrm{~cm}$ mineral soil) for fine and coarse root biomass and necromass.

\subsubsection{STATISTICAL ANALYSIS}

All data were tested for gaussian distribution with a Shapiro \& Wilk test. Differences between the five stands in aboveground structural parameters were analysed with a nonparametric analysis of variance (Kruskal-Wallis test) and a Mann-Whitney two-sample test (Wilcoxon U-test). Linear regression analyses were conducted for identifying significant effects of elevation, mean annual temperature, $\mathrm{C} / \mathrm{N}$ and $\mathrm{pH}$ on selected root and shoot parameters. Non-linear equations were used to describe the relation between elevation or temperature and FRB/FRN ratios. All calculations were done with SAS/STAT or Xact software $(\mathrm{p}<0.05)$.

\subsection{RESULTS}

\subsubsection{ALTITUDINAL CHANGE IN ABOVEGROUND STAND STRUCTURE AND BIOMASS}

Across the 2000-m range in the transect, large changes in average tree height $(\mathrm{H})$, diameter at breast height (D) and stem density were observed (Tab.4.2). The trees in the lowermost stand (\#1 at $1050 \mathrm{~m}$ ) had, on average, a 2.5-fold larger D and a three times greater height than those in the uppermost stand (\#5 at $3060 \mathrm{~m}$ ). Stem density (967-8317 ha-1) increased by a factor of 8.5 along the transect. However, stand basal area showed no significant altitudinal trend. AGB as estimated with a height- and diameter-based allometric regression decreased by two-thirds from 1050 to $3060 \mathrm{~m}\left(21-7 \mathrm{~kg} \mathrm{~m}^{-2}\right)$. A second regression equation which only uses stem diameter yielded a reduction by roughly $30 \%$ only (Tab.4.3).

Table 4.3: Estimates of aboveground tree biomass as derived from two different allometric equations (after Brown \& Iverson 1992 and Brown 1997).

\begin{tabular}{llll}
\hline Stand & Elevation $(\mathrm{m})$ & Eq. (1) & Eq. (2) \\
\hline 1 & 1050 & 20799 & 22040 \\
2 & 1540 & 11845 & 12890 \\
3 & 1890 & 13218 & 19900 \\
4 & 2380 & 7464 & 12720 \\
5 & 3060 & 7384 & 15640 \\
\hline
\end{tabular}

Eq. (1): $\ln y=-3.375+0.948 \ln \left(D^{2} \cdot H\right)$, Eq. (2): $y=21.297-6.953 \cdot D+0.740 \cdot D^{2} ; y=$ aboveground biomass $\left(\mathrm{g}\right.$ dry matter $\left.\mathrm{m}^{-2}\right), \mathrm{D}=$ diameter at breast height $(\mathrm{D}$, in $\mathrm{cm})$ and tree height $(\mathrm{H}$, in $\mathrm{m})$ were investigated for plots that contained 80 trees of all diameters;. 


\subsubsection{ALTITUDINAL CHANGE IN ROOT BIOMASS AND ROOT/SHOOT RATIO}

The FRB of trees in the organic layer and the mineral soil to $30 \mathrm{~cm}$ depth showed a highly significant increase from $268 \mathrm{~g} \mathrm{~m}^{-2}$ at $1050 \mathrm{~m}$ to $1127 \mathrm{~g} \mathrm{~m}^{-2}$ at $3060 \mathrm{~m}$ (Fig.4.1). We also found a large and highly significant increase in FRN with elevation (167-3106 $\mathrm{g} \mathrm{m}^{-2}$ ). Both FRB and FRN were negatively related to temperature (Tab.4.4). The biomass of coarse roots (diameter 2-5 mm) ranged between 240 and $760 \mathrm{~g} \mathrm{~m}^{-2}$ in the first four stands but increased greatly at $3060 \mathrm{~m}\left(2040 \mathrm{~g} \mathrm{~m}^{-2}\right.$, Fig.4.1).

Coarse root necromass was comparably small at all sites with the highest value again found in the highest stand (data not shown). For the FRB/FRN ratio, we found a highly significant exponential decrease with elevation from a ratio of 2.4 at $1050 \mathrm{~m}$ to a ratio $<0.4$ at 2380 and $3060 \mathrm{~m}$ (Fig.4.2). As a consequence, FRB / FRN increased expo- nentially with temperature (Fig.4.2). This relationship was similar for the organic layer and the mineral soil (Tab.4.4).
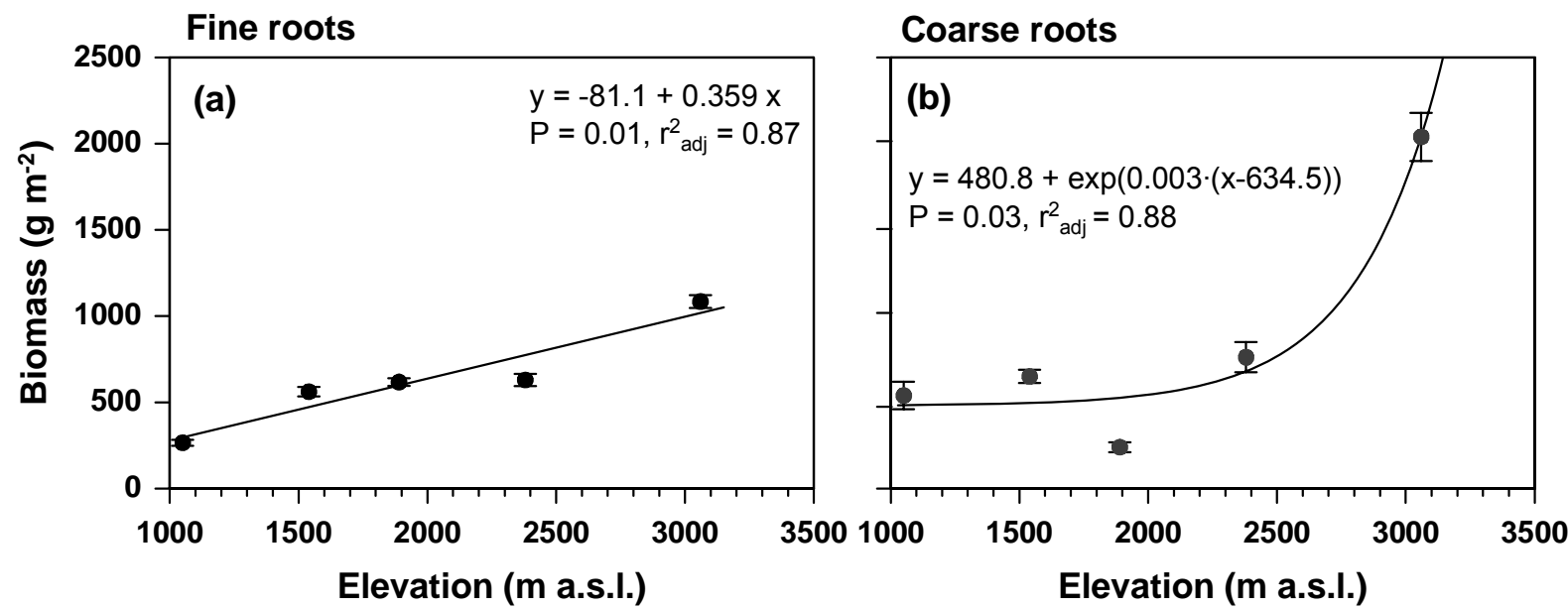

Figure 4.1: Elevational change of (a) fine root biomass (diameter $<2 \mathrm{~mm}$, means and $\mathrm{SE}, \mathrm{n}=20$ ) and (b) and coarse root biomass (diameter $2-5 \mathrm{~mm}, \mathrm{n}=15$ ). Consequently, $\mathrm{R} / \mathrm{S}$ increased more than 10 fold from 0.04 to 0.43 between 1050 and $3060 \mathrm{~m}$ and showed a significant relation to both soil $\mathrm{C} / \mathrm{N}$ and $\mathrm{pH}$ (Tab.4.4).

Table 4.4: Regression analyses of fine root biomass and necromass, fine root biomass/necromass ratio, and root biomass/aboveground biomass (root/shoot; fine and coarse roots) ratio against mean air temperature, $\mathrm{C} / \mathrm{N}$ ratio (organic L/Of1 horizon) and $\mathrm{pH}\left(\mathrm{H}_{2} \mathrm{O}\right)$ (mineral soil: $0-10 \mathrm{~cm}$ ).

\begin{tabular}{|c|c|c|c|c|c|c|}
\hline & \multicolumn{2}{|c|}{ Temperature } & \multicolumn{2}{|l|}{$\mathrm{C} / \mathrm{N}$} & \multicolumn{2}{|l|}{$\mathrm{pH}$} \\
\hline & $\mathrm{p}$ & $r_{a d j}^{2}$ & $p$ & $r_{\text {adj }}^{2}$ & $\mathrm{p}$ & $r_{a d j}^{2}$ \\
\hline Fine root biomass (profile total $^{a}$ ) & 0.03 & 0.78 & 0.02 & 0.82 & 0.18 & 0.34 \\
\hline Fine root necromass (profile total ${ }^{a}$ ) & 0.03 & 0.77 & 0.01 & 0.88 & 0.13 & 0.45 \\
\hline Fine root biomass/necromass ratio (org lay) & 0.04 & 0.70 & 0.25 & 0.21 & 0.01 & 0.87 \\
\hline Fine root biomass/necromass ratio (min soil) & 0.02 & 0.82 & 0.04 & $0.82^{b}$ & 0.07 & 0.62 \\
\hline Root/shoot ratio & 0.07 & 0.62 & 0.01 & 0.94 & 0.01 & $0.96^{b}$ \\
\hline
\end{tabular}

Data for the $\mathrm{C} / \mathrm{N}$ ratio of the mineral soil, which had a smaller influence than the organic layer $\mathrm{C} / \mathrm{N}$, is not shown. Non-linear regressions of the type $y=a+\exp (c(x-b))$ were applied in the case of the $\mathrm{C} / \mathrm{N}$ effect on the biomass/necromass ratio and the $\mathrm{pH}$ effect on root/shoot ratio (for equations see Fig.4.2). Relationships significant at $\mathrm{p}<0.05$ are printed in italic.

${ }^{\mathrm{a}}$ Organic layer and mineral soil $(0-30 \mathrm{~cm})$.

${ }^{\mathrm{b}}$ Non-linear regressions. 
FRB, FRN and FRB/FRN were also positively correlated with the $\mathrm{C} / \mathrm{N}$ ratio which increased upslope. In contrast, soil $\mathrm{pH}$ did influence only one root parameter (FRB/FRN of the organic layer).

Figure 4.3 contrasts the AGB estimates of the five stands as obtained in Eq. (1) with the corresponding approximate root biomass data (fine and coarse) and gives the root biomass/AGB ratio (R/S). A decrease in AGB to less than a half between 1050 and $3060 \mathrm{~m}$ corresponded with a four-fold increase in fine and coarse root biomass

\subsection{DISCUSSION}

\subsubsection{ABOVEGROUND FOREST STRUCTURE AND BIOMASS}

While average tree height $(\mathrm{H})$ of all stems over $50 \mathrm{~mm}$ in diameter decreased linearly with elevation by $5.2 \mathrm{~m} \mathrm{~km}^{-1}\left(\mathrm{y}=20.3-0.0052 \cdot \mathrm{x}, \mathrm{p}=0.002, \mathrm{r}^{2}{ }_{\mathrm{adj}}=0.96\right)$, we found an exponential decrease of maximum tree height along the 2000-m altitudinal transect $(y=-8.1+50912 / x$, $\mathrm{p}<0.001, \mathrm{r}^{2}{ }_{\text {adj }}=0.99$ ) due to a large size reduction in emergent trees along the slope. In contrast to tree height, basal area remained more or less constant with elevation because the linear decrease in mean diameter at breast height (D) of the stems was compensated by a large increase in stem density between the lowermost and uppermost stands. This large increase in stem density with elevation may have different reasons. Periodic disturbance by strong winds at high elevations may favour small trees with limited crown extension over large ones with broad canopies allowing for higher stem densities. Further, when more $\mathrm{C}$ has to be allocated to the belowground compartment, then it may pay to have more numerous relatively small stems with conducting pathways than a few thick stems. In lowland heath forests with a large root biomass the stem density is also much higher than in moist lowland rain forest on average soils (Whitmore 1998).
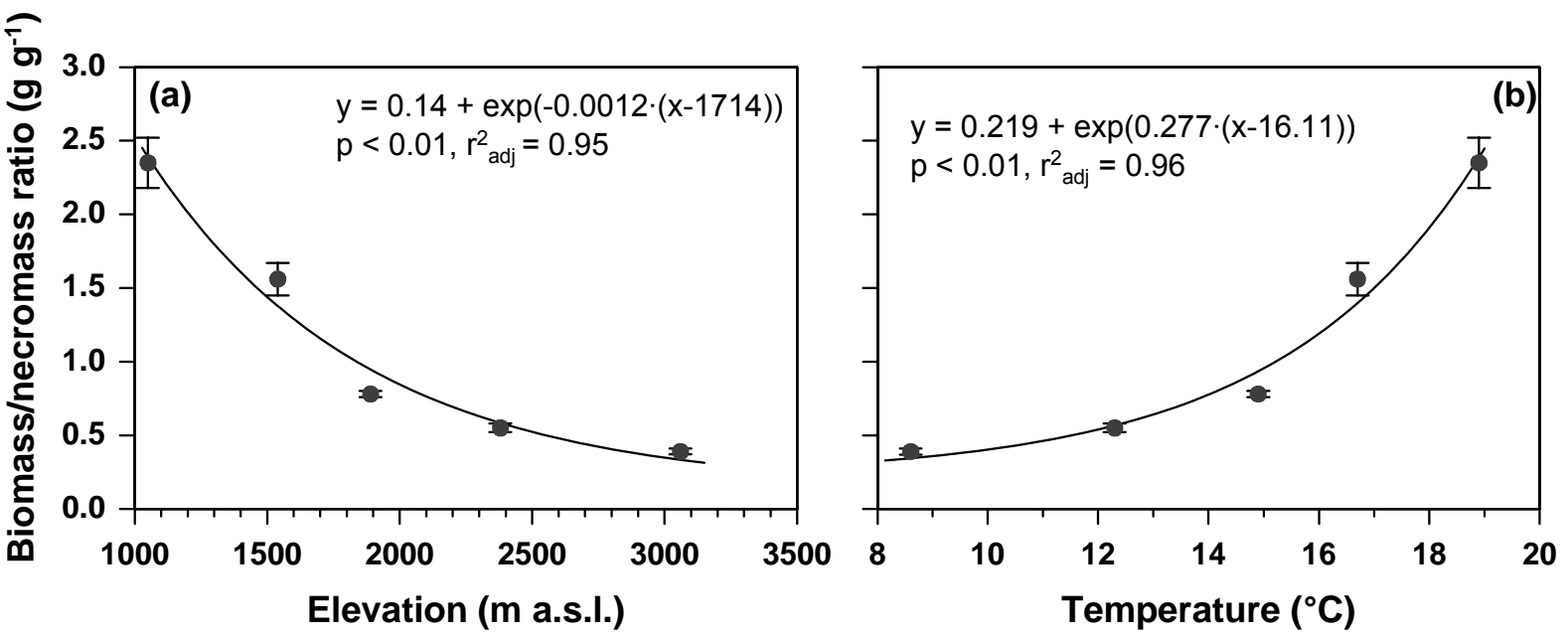

Figure 4.2: Fine root biomass/necromass ratio in the upper soil profiles (organic layer and $0-30 \mathrm{~cm}$ of mineral soil) as a function of elevation (a) or mean air temperature (b) (means and SE, $n=20$ ).

Our estimates of AGB with two widely used allometric regression equations for tropical moist forests can give only rough estimates of tree biomass. In the lowermost stand, the results obtained with the parameters $\mathrm{D}$, or $\mathrm{D}$ and $\mathrm{H}$, differed by less than $10 \%$. However, the discrepancy was much larger in the high-elevation forests (more than $100 \%$ difference) indicating that these regressions, which were mainly derived from inventories in lowland 
forests, LAI showed a decrease from about 5.1-2.9 along the transect. This implies a reduction in carbon gain toward higher elevations and thus offers one explanation for the decrease in tree height and AGB. Similar reductions in LAI with elevation were reported by Kitayama \& Aiba (2002) along a transect on Mt. Kinabalu (Malaysia). They suggested an effect of decreasing temperature which would act either directly on leaf expansion or indirectly through soil processes and nutrient availability.

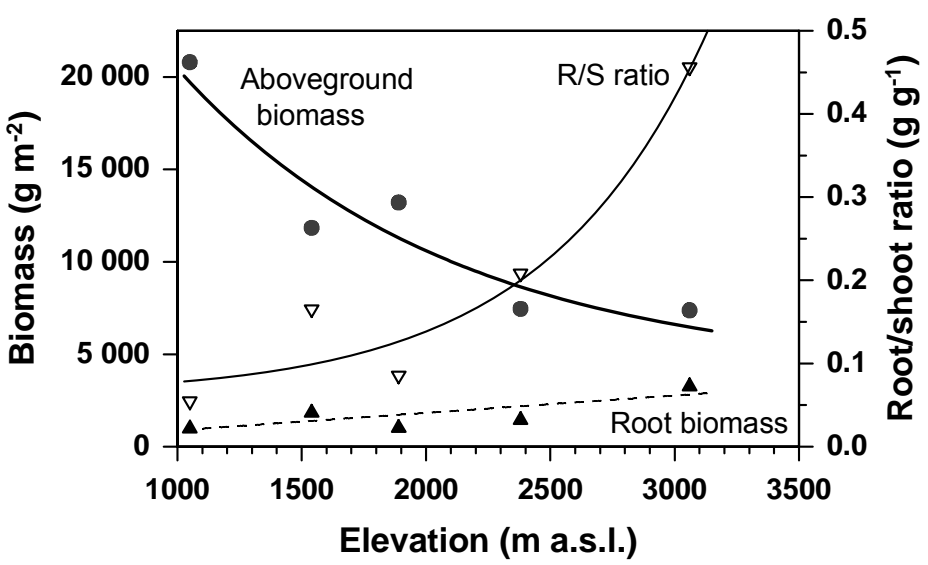

Figure 4.3: Elevational change of above-ground biomass (AGB), root biomass (RB) and root/aboveground biomass ratio (root/shoot ratio, R/S) in the five forest stands. AGB was estimated with the equation $\ln y=-3.375+0.948 \ln \left(D^{2} \cdot H\right)$. RB includes fine and coarse roots of the organic layer and mineral soil to $30 \mathrm{~cm}$. The increase in (total) root biomass is not significant. Equations: AGB: $\mathrm{y}=3916+\exp (-0.0009(\mathrm{x}-11724)), \quad \mathrm{p}=0.048, \quad \mathrm{r}_{\mathrm{adj}}^{2}=0.80 ; \quad \mathrm{RB}: \mathrm{y}=-164.9+0.94 \mathrm{x}, \quad \mathrm{p}=0.12$, $\mathrm{r}_{\text {adj }}^{2}=0.47 ; \mathrm{R} / \mathrm{S}: \mathrm{y}=0.06+\exp (0.0015(\mathrm{x}-3672)), \mathrm{p}=0.03, \mathrm{r}_{\mathrm{adj}}^{\mathrm{ad}}=0.87$.

\subsubsection{FINE ROOT BIOMASS IN TROPICAL MOUNTAIN FORESTS}

Our FRB data (270-1100 $\left.\mathrm{g} \mathrm{m}^{-2}\right)$ are within the range reported for other tropical mountain forests. Literature data range from $150 \mathrm{~g} \mathrm{~m}^{-2}$ (Hawaii: Herbert \& Fownes 1999) or 200-300 $\mathrm{g} \mathrm{m}^{-2}$ (Colombia and India: Cavelier et al. 1996, Sundarapandian \& Swamy 1996) to $4800 \mathrm{~g}$ $\mathrm{m}^{-2}$ (Costa Rica and tropical Australia: Maycock \& Congdon 2000, Vance \& Nadkarni 1992) or even $>1100 \mathrm{~g} \mathrm{~m}^{-2}$ in UMFs of Costa Rica (Hertel et al. 2003). The large variation in FRB may partly reflect differences in species composition and/or environmental conditions of the forests studied. However, different sampling methods most likely contributed to this large variation as well.

According to our knowledge, there exists only the study by Kitayama \& Aiba (2002) on altitudinal gradients in FRB on tropical mountains. These authors found a large increase in FRB in two altitudinal transects from 700 to 3100 m a.s.1. on Mt. Kinabalu, Malaysia (560$1020 \mathrm{~g} \mathrm{~m}^{-2}$ and $520-1440 \mathrm{~g} \mathrm{~m}^{-2}$ in profiles to $30 \mathrm{~cm}$ depth, respectively). The fine root data of Silver et al. (1999) cover only a very short altitudinal distance. Our FRB data are in the same range as those from Malaysia; we also found an altitudinal increase in the biomass of coarse roots (diameter: 2-5 mm) which mainly function as conducting elements. In most altitudinal transect studies which span more than $1000 \mathrm{~m}$ as in our study different geological parent materials are inevitably included. This may introduce some inhomogeneity with respect to soil chemical conditions and perhaps can explain why the $\mathrm{C} / \mathrm{N}$ ratio of site 3 is lower than the ratio of site 2 which is opposite the general trend. Nevertheless, summarising the two transect studies from Ecuador and Malaysia and adding other sporadic FRB data from tropical regions, there is evidence that (i) FRB generally is higher in tropical montane forests than in lowland forests and (ii) FRB tends to increase upslope toward the timberline. 
Accurate FRB data from altitudinal transects in mountain forests of other climatic zones do not exist. Körner (2003) concluded from a literature survey that young trees in temperate mountains apparently do not change their carbon allocation patterns significantly with elevation. If this were correct it would contrast with allocation patterns found in temperate herbaceous plants. Indeed, alpine perennial herbs have been found to produce four to five times more FRB per unit leaf area than herbs form low altitudes (Körner \& Renhardt 1987). This may suggest that woody plants in temperate mountains should also have higher root/shoot ratios at high elevations than lowland trees. We believe that an increase in root/shoot ratio, or even an absolute increase in FRB, with elevation may be the rule and not the exception in mountain forests.

\subsubsection{SINK LIMITATION OF TREE GROWTH IN TROPICAL MOUNTAIN FORESTS?}

The most remarkable result of our study is the opposite trend in AGB (large decrease) and FRB (large increase) along the 2000-m altitudinal transect resulting in a large increase in root/shoot ratio. Similarly, Kitayama \& Aiba (2002) found a large altitudinal increase in the FRB/AGB ratio from 700 to $3100 \mathrm{~m}$ on Mt. Kinabalu which is in line with our findings. Thus, these two studies in neotropical and paleotropical mountain forests both found evidence of an altitudinal change in tree carbon partitioning patterns.

Since fine roots of trees suffer from significant carbon losses through respiration and exudation, and also transfer substantial amounts of $\mathrm{C}$ to mycorrhizal hyphae, they are probably more costly in terms of $\mathrm{C}$ consumption than are leaves or stems. A substantial increase in root biomass as observed in this study might therefore indicate an increasing, rather than a decreasing, $\mathrm{C}$ sink strength of the root system with increasing elevation. This would imply that the temperature decrease from 19 to $8^{\circ} \mathrm{C}$ between 1050 and $3060 \mathrm{~m}$ cannot have had a limiting effect on $\mathrm{C}$ allocation to roots because the size of the fine and coarse root systems increased with elevation. On the other hand, the altitudinal decrease in LAI points at a reduced stand carbon gain in high elevation forests of our transect because incident photosynthetically active radiation remained more or less constant with elevation along the 2000-m transect (M. Unger, unpubl. results). Therefore, carbon must have been increasingly allocated to roots with increasing elevation despite a lowered $\mathrm{C}$ source strength of the canopy. Since neither fine root production nor respiration data is yet available for the study region, however, these assumptions on carbon fluxes from aboveground to belowground tree compartments must remain speculative.

Nevertheless, from the impressive shift in the tree root/shoot ratio along the slope we conclude that the carbon allocation patterns and their control by environmental gradients must be a key for explaining the altitudinal reduction in AGB in tropical mountain forests. Bloom et al. (1985) suggested that plants respond to imbalances in resource availability by adjusting their $\mathrm{C}$ allocation so that the limitation for growth is equalized for all resources as much as possible. Accordingly, increasing allocation to fine roots on the cost of AGB is indicating a growing relative importance of limiting soil resources, i.e. nutrients and/or water. Since average soil water content increased from 1050 to $3060 \mathrm{~m}$ in our transect, water shortage should not be limiting plant growth at high elevation. Rather, water logging in the soil may have hampered mineralization at the highest site presumably reducing nutrient supply. Compared to other tropical montane forests, rainfall is very high with 5000 $\mathrm{mm}$ at $2380 \mathrm{~m}$ elevation which favours water saturation of the soil. We hypothesize that the increasing FRB with elevation is caused by an increasing importance of nutrient limitation of tree growth.

Root inventories in tropical forests have shown that the predictions on root growth made by the source-sink theory of resource allocation of Bloom et al. (1985) are valid. In stands on fertile soils, a substantially smaller FRB was found than in stands on infertile soils 
(Vitousek \& Sanford 1986) with the availability of P and Ca being more influential on root biomass than that of N (Gower 1987, Maycock \& Congdon 2000).

What are the underlying causes of a decreasing nutrient availability with increasing elevation? Temperature may play an important role, but edaphic and chemical factors such as water logging, altitudinal increases in the concentrations of hydrogen ions, free aluminium or phenols in the soil solution, or low nitrogen and high lignin contents of the litter could be influential as well since all are known to slow down decomposition (Berg \& McClaugherty 2003). In our transect, large $\mathrm{C} / \mathrm{N}$ ratios in the organic layer and the mineral topsoil of the uppermost stands indicate nitrogen limitation of decomposer activity at high elevations and thus low mineralisation rates. $\mathrm{P}$ or $\mathrm{N}$ limitation of microbial activity at high elevations could also explain reduced decomposition rates of fine root litter and subsequent accumulation of large amounts of root necromass as were observed especially in the stands at 2380 and $3060 \mathrm{~m}$. In addition, a soil water content averaging at 47vol.\% at the uppermost site clearly indicates oxygen deficiency for extended periods. However, all other abovementioned constraints on nutrient supply may similarly cause increased carbon allocation to roots and reduced tree height growth in tropical trees, independently of any temperature or elevation effect. This was shown when studying the ecotones from tropical lowland moist forest to lowland heath forest with stunted growth on soils with very low nutrient supply rates (Klinge \& Herrera 1983). For disentangling the complex interaction between nutrient supply and environmental factors, experimental studies have recently been initiated in these Ecuadorian high elevation forests.

With respect to temperature, at least three causal chains seem possible leading from lowered temperatures to altitudinal increases in FRB: low temperatures may

(i) reduce microbial nutrient mineralisation rates (mainly of $\mathrm{P}$ and $\mathrm{N}$ ) and thus can diminish nutrient supply to the roots, because nutrient supply through mineralisation of litter has been found to be strongly dependent on temperature (Ellert \& Bettany 1992, Kirschbaum 1995),

(ii) reduce the abundance and activity of mycorrhizal fungi and restrict their nutrient supply functions, or

(iii)lead to substantial reductions in nutrient uptake rates of the roots because carrier activity in the plasma membranes is temperature sensitive.

Each of these factors may cause nutrient limitation of tree growth and thus should stimulate carbon allocation to roots. Given that sufficient carbon is acquired by the canopy, nutrient shortage could result in the build-up and permanent maintenance of a larger root system resulting in increased nutrient uptake. Consequently, the carbon cost of nutrient acquisition would increase.

Our altitudinal transect encompasses multiple variables that may change independently of each other. For part of the variables such as free aluminium and oxygen deficiency, quantitative data are lacking. From the inverse relation between root biomass and soil fertility found in tropical lowland and montane forests (Gower 1987, Cavelier 1992, Maycock \& Congdon 2000, Stewart 2000) we expected a particularly high FRB in the stands with largest $\mathrm{C} / \mathrm{N}$ ratio. Indeed, our data show a significant inverse relation between $\mathrm{FRB}$ and soil $\mathrm{C} / \mathrm{N}$. The regression analyses suggest that both temperature and nitrogen availability are more important than is soil acidity. However, both temperature and $\mathrm{C} / \mathrm{N}$ ratio of the topsoil showed a close negative correlation to each other in our transect $(p=0.05$, $\left.r^{2}{ }_{a d j}=0.92\right)$ which makes it difficult to separate between the two factors. The altitudinal increase of $\mathrm{C} / \mathrm{N}$ ratio in the uppermost litter layer indicates that $\mathrm{N}$ return with plant litter decreases with increasing elevation and lowered temperatures. It must remain open whether temperature acts directly on nutrient supply through the mechanisms (i)-(iii) discussed 
above, or indirectly through a temperature effect on plant nutrient economy and $\mathrm{N}$ return with litter fall.

FRN showed a similarly close relation to temperature and also to soil $\mathrm{C} / \mathrm{N}$ as did biomass. This may result either from a slowing down of root litter decomposition, or from reduced root longevity in unfavourable soil environments at high elevations which enhances root turnover. From a literature survey, Lauenroth \& Gill (2003) concluded that root turnover in forests increases with temperature but decreases with the annual thermal amplitude. Thus, tropical mountain forests should have comparably low turnover rates. On the other hand, increasing soil acidity and decreasing base saturation were found to stimulate fine root turnover in temperate forests (Jentschke et al. 2001, D. Hertel \& C. Leuschner unpubl. results). Again, water logging could also play a role. Thus, increasing elevation but decreasing temperature could influence fine root turnover either positively or negatively.

We conclude that the fine root system and its activity may hold the key for understanding the impressive reduction in tree size along tropical mountain slopes. Analyses of fine root turnover and longevity along altitudinal transects in tropical mountains in combination with environmental variables and biogeochemical fluxes are needed for fully understanding the role of roots and tree carbon partitioning in tropical high-elevation forests. Moreover, measurements of photosynthesis and respiration are urgently needed to establish the carbon balance of montane forests.

\subsection{ACKNOWLEDGEMENTS}

This research was conducted in the context of the collaborative research project Forschergruppe 402 (Funktionalität in einem tropischen Bergregenwald Südecuadors, subproject B7) funded by DFG (German Science Foundation). The financial support is gratefully acknowledged. We also thank P. Emck (University of Erlangen), S. Iost and F. Makeschin (Technical University of Dresden), and J. Homeier (University of Göttingen) for making data on climate, soil chemistry and LAI available to us. We thank the Ministerio del Ambiente Loja y Zamora-Chinchipe for granting the necessary research permit, and Fundación Científica San Francisco for the ongoing support at ECSF.

\subsection{REFERENCES}

Ashton, P.S. 2003. Floristic zonation of tree communities on wet tropical mountains revisited. Perspectives in Plant Ecology, Evolution and Systematics 6: 87-104.

Balslev, H., Øllgaard, B. 2002. Mapa de vegetacion del sur de Ecuador. In: Aguirre M., Madsen, J.E., Cotton, E., Balslev, H. (eds.), Botanica Austroecuadoriana. Estudios sobre los recursos vegetales en las provincias de El Oro, Loja y Zamora-Chinchipe. Ediciones Abya-Yala, Quito, Ecuador. pp. 51-64.

Bauhus, J., Bartsch, N. 1996. Fine-root growth in beech (Fagus sylvatica) forest gaps. Canadian Journal of Forest Research 26: 2153-2159.

Bloom, A.J., Chapin III, F.S., Mooney, H.A. 1985. Resource limitation in plants - an economic analogy. Annual Review of Ecology and Systematics 16: 363-392.

Brown, S. 1997. Estimating biomass and biomass change of tropical forests. A primer. FAO Forestry paper 134. FAO, Rome.

Brown, S., Iverson, L.R. 1992. Biomass estimates for tropical forests. World Resources Review 4: 366-384.

Bruijnzeel, L.A., Proctor, J. 1995. Hydrology and biogeochemistry of tropical montane cloud forests: what do we really know? In: Hamilton, L.S., Juvik, J.O., Scatena, F.N. (eds.) Tropical montane cloud forests. Springer, New York. pp. 38-78. 
Bruijnzeel, L.A., Veneklaas, E.J. 1998. Climatic conditions and tropial montane forest productivity: the fog has not lifted yet. Ecology 79: 3-9.

Cairns, M.A., Brown, S., Helmer, E.H., Baumgardner, G.A. 1997. Root biomass allocation in the world's upland forests. Oecologia 111: 1-11.

Cavelier, J. 1992. Fine-root biomass and soil properties in a semideciduous and a lower montane rain forest in Panama. Plant and Soil 142: 187-201.

Cavelier, J., Estevez, J., Arjona, B. 1996. Fine root biomass in three successional stages of an Andean cloud forest in Colombia. Biotropica 28: 728-736.

Ellert, B.H., Bettany, J.R. 1992. Temperature dependence of net nitrogen and sulfur mineralization. Soil Sciences Society of America Journal 56: 1133-1141.

Flenley, J.R. 1995. Cloud forest, the Massenerhebung Effect, and ultraviolet insolation. In: Hamilton, L.S., Juvik, J.O., Scatena, F.N. (eds.). Tropical montane cloud forests. Ecological Studies 110. Springer, New York. pp. 150-155.

Gower, S.T. 1987. Relations between mineral nutrient availability and fine root biomass in two Costa Rican tropical forests: a hypothesis. Biotropica 19: 171-175.

Grubb, P.J. 1977. Control of forest growth and distribution on wet tropical mountains: with special reference to mineral nutrition. Annual Review of Ecology and Systematics 8: 83-107.

Hafkenscheid,R.L.L.J., 2000. Hydrology and biogeochemistry of tropical montane rain forests of contrasting stature in the Blue Mountains, Jamaica. Dissertation Universiteit Amsterdam, Print Partners Ipskamp, Enschede, The Netherlands.

Herbert, D.A., Fownes, J.H. 1999. Forest productivity and efficiency of resource use across a chronosequence of tropical montane soils. Ecosystems 2: 242-254.

Hertel, D. 1999. Das Feinwurzelsystem von Rein- und Mischbeständen der Rotbuche: Struktur, Dynamik und interspezifische Konkurrenz. Dissertationes Botanicae 317: 1206.

Hertel, D., Leuschner, Ch. 2002. A comparison of four different fine root production estimates with ecosystem carbon balance data in a Fagus-Quercus mixed forest. Plant and Soil 239: 237-251.

Hertel, D., Leuschner, Ch., Hölscher, D. 2003. Size and structure of fine root systems in old-growth and secondary tropical montane forests (Costa Rica). Biotropica 35: 143153.

Hetsch, W., Hoheisel, K. 1976. Standorts- und Vegetationsgliederung in einem tropischen Nebelwald. Allgemeine Forst- und Jagdzeitung, 147: 200-209.

Homeier, J. 2004. Baumdiversität, Waldstruktur und Wachstumsdynamik zweier tropischer Bergregenwäldern in Ecuador und Costa Rica. Dissertationes Botanicae 391. 207 pp.

Jentschke, G., Drexhage, M., Fritz, H.-W., Fritz, E., Schella, B., et al. 2001. Does soil acidity reduce subsoil rooting in Norway spruce (Picea abies)? Plant and Soil 237: 91108.

Kirschbaum, M.U.F. 1995. The temperature dependence of soil organic matter decomposition, and the effect of global warming on soil organic storage. Soil Biology and Biochemistry 27: 753-760.

Kitayama, K. \& Aiba, S.-I. 2002. Ecosystem structure and productivity of tropical rain forests along altitudinal gradients with contrasting soil phosphorus pools on Mount Kinabalu, Borneo. Journal of Ecology 90: 37-51.

Klinge, H., Herrera, R. 1983. Phytomass structure of natural plant communities on spodosols in southern Venezuela. Vegetatio 53: 65-84.

Knievel, D. P. 1973. Procedure for estimating ratio of living and dead root dry matter in root core samples. Crop Science 13: 124-126.

Körner, Ch. 2003. Alpine Plant Life. Functional plant ecophysiology of high mountain ecosystems. (2nd ed.). Springer, Berlin. 
Körner, Ch., Renhardt, U. 1987. Dry matter partitioning and root length/leaf area ratios in herbaceous perennial plants with diverse altitudinal distribution. Oecologia 74: 411418.

Lauenroth, W.K., Gill, R. 2003. Turnover of root systems. In: de Kroon, H., Visser, E.J.W. (eds.). Root Ecology. Springer, Berlin. Ecological Studies 168: 61-89.

Maycock, C.R., Congdon, R.A. 2000. Fine root biomass and soil $\mathrm{N}$ and $\mathrm{P}$ in north Queensland rain forests. Biotropica 32: 185-190.

Perrson, H. 1978. Root dynamics in a young Scots pine stand in Central Sweden. Oikos 30: 508-519.

Schrumpf, M., Guggenberger, G., Valarezo, C., Zech, W. 2001. Tropical montane rain forest soils - Development and nutrient status along an altitudinal gradient in the South Ecuadorian Andes. Die Erde 132: 43-59.

Silver, W.L., Keller, M., Lugo, A.E. 1999. Soil oxygen availability and biogeochemical cycling along elevation and topographic gradients in Puerto Rico. Biogeochemistry 44: 301-328.

Stewart, C.G. 2000. A test of nutrient limitation in two tropical montane forests using root ingrowth cores. Biotropica 32: 369-373.

Sugden, A.M. 1986. The montane vegetation and flora of Margarita Island, Venezuela. Journal of the Arnold Arboretum 67: 187-232.

Sundarapandian, S.M., Swamy, P.S. 1996. Fine root biomass distribution and productivity patterns under open and closed canopies of tropical forest ecosystems at Kodayar in Western Ghats, South India. Forest Ecology and Management 86: 181-192.

Tanner, E.V.J., Vitousek, P.M., Cuevas, E. 1998. Experimental investigation of nutrient limitation of forest growth on wet tropical mountains. Ecology 79: 10-22.

Valencia, R., Ceron, C., Palacios, W., Sierra, R. 1999. Las formaciones naturales de la sierra del Ecuador. In: R. Sierra (ed.), Propuesta preliminar de un sistema de clasificacion de vegetacion para el Ecuador continental. Proyecto INEFAN/GEF-BIRF y EcoCiencia, Quito. pp. 79-108.

Vance, E.D., Nadkarni, N.M. 1992. Root biomass distribution in a moist tropical montane forest. Plant and Soil 142: 31-39.

van Praag, H.J., Sougnez-Remy, S., Weissen, F., Carletti, G. 1988. Root turnover in a beech stand of the Belgian Ardennes. Plant and Soil 105: 87-103.

Van Steenis, C.G.G.J. 1972. The mountain flora of Java. Leiden, E.J.Brill.

Vitousek, P.M., Sanford, R.L. 1986. Nutrient cycling in moist tropical forest. Annual Review of Ecology and Systematics 17: 137-167.

Vogt, K.A., Vogt, D.J., Palmiotto, P.A., Boon, P., O’Hara, J., \& Asbjornson, H. 1996. Review of root dynamics in forest ecosystems grouped by climate, climatic forest type and species. Plant and Soil 187: 159-219.

Whitmore, T.C. 1998. An introduction to tropical rain forests (2nd ed.). Oxford, Oxford University Press. 


\section{ALTITUDINAL CHANGE IN LAI AND \\ STAND LEAF BIOMASS IN TROPICAL MONTANE FORESTS: \\ A TRANSECT STUDY IN ECUADOR \\ AND A PAN-TROPICAL META-ANALYSIS*}

\subsection{ABSTRACT}

Leaf area index (LAI) is a key parameter controling plant productivity and biogeochemical fluxes between vegetation and the atmosphere. Tropical forests are thought to have comparably high LAIs; however, precise data are scarce and environmental controls of leaf area in tropical forests are not understood. We studied LAI and stand leaf biomass by optical and leaf mass-related approaches in five tropical montane forests along an elevational transect (1050 to $3060 \mathrm{~m}$ a.s.1.) in South Ecuador, and conducted a metaanalysis of LAI and leaf biomass data from tropical montane forests around the globe. Study aims were (1) to assess the applicability of indirect and direct approaches of LAI determination in tropical montane forests, (2) to analyse elevation effects on leaf area, leaf mass and important leaf traits (SLA, leaf lifespan), and (3) to assess the possible consequences of leaf area change with elevation for montane forest productivity. Indirect optical methods of LAI determination appeared to be less reliable in the complex canopies than direct leaf mass-related approaches based on litter trapping and a thorough analysis of leaf lifespan. LAI decreased by 40 to $60 \%$ between 1000 and $3000 \mathrm{~m}$ in the Ecuador transect and also in the pan-tropical data set. This decrease indicates that canopy carbon gain, i.e. carbon source strength, decreases with elevation in tropical montane forests. Average SLA decreased from 88 to $61 \mathrm{~cm}^{2} \mathrm{~g}^{-1}$ while leaf lifespan increased from 16 to 25 mo between 1050 and $3060 \mathrm{~m}$ in the Ecuador transect. In contrast, stand leaf biomass was much less influenced by elevation. We conclude that elevation has a large influence not only on the leaf traits of trees but also on the LAI of tropical montane forests with soil $\mathrm{N}$ supply presumably being the main controling factor.

5.2 KEYWORDS: Elevation gradient, LAI, leaf biomass, leaf lifespan, leaf litter production, specific leaf area, tropical montane forest

\footnotetext{
* published in Ecosystems 10: G. Moser, D. Hertel, Ch. Leuschner 2007. Altitudinal change in LAI and stand leaf biomass in tropical montane forests: a transect study in Ecuador and a pan-tropical meta-analysis. Pp. 924-935. With kind permision from Springer Science and Business Media. C 2007 Springer.
} 


\subsection{INTRODUCTION}

Stand leaf area is a key parameter in the functioning of forests that controls carbon gain and the exchange of energy and water between the canopy and the atmosphere. Leaf area index (LAI), the cumulative one-sided surface area of the leaves in the canopy per unit ground area, is the most widely recorded parameter of stand leaf area. It can be determined either by direct biomass harvest methods, by litter trapping, or indirect optical techniques (Asner et al. 2003). In evergreen tropical forests, LAI measurement is difficult because harvest methods are very labour-intensive, simple litter trapping is not applicable in the absence of a clear seasonality in leaf fall, and optical techniques have been found to be problematic in the complex multi-layered canopies (Clark et al. 2001, McWilliam et al. 1993). According to Chason et al. (1991), Fassnacht et al. (1994) and Mussche et al. (2001), indirect optical methods generally tend to underestimate high LAIs, but overestimate low leaf area indices in forests.

Due to the methodological problems encountered, our knowledge about the LAI of tropical moist forests and its dependence on climate, soil and topography is still very limited (Clark et al. 2001). Moreover, only a small number of authors studied changes in tropical forest leaf area across environmental gradients (e.g. Herbert \& Fownes 1999, Kitayama \& Aiba 2002, Takyu et al. 2003). However, expected future change in the environment of tropical forests, including a rise of temperature, drought frequency and nitrogen input, demands a more precise understanding of the dependency of leaf area and productivity of tropical forests on the environment. Attempts to model changes in productivity and biogeochemical fluxes in tropical forests for the coming decades will be heavily dependent on reliable estimates of LAI and its variation across landscapes and forest types.

When attempting to improve the quantity and quality of leaf area data for tropical forests, a critical assessment of existing methods is a basic requirement, in particular with respect to the comparability of indirect optical and direct leaf mass-related approaches. Methodological comparisons have been conducted repeatedly in boreal, temperate and subtropical forests (Barclay \& Trofymow 2000, Bréda 2003, Chason et al. 1991, Comeau et al. 1998, Dufrêne and Bréda 1995, Fassnacht et al. 1994, Gower et al. 1999, Jonckheere et al. 2004, Küßner \& Mosandl 2000, Smith et al. 1991, Weiss et al. 2004, Whitford et al. 1995), often by comparing one or two different optical methods (including the LAI-2000 canopy analyser and hemispherical photography) with litter trapping or leaf harvest techniques (e.g. Mussche et al. 2001). An equivalent comparison for tropical forests is still missing.

Based on a field study in an elevational transect in the South Ecuadorian Andes and a literature survey, that covered all available leaf area and leaf mass data from tropical lower montane to upper montane forests, the present study attempts to reach three goals, (1) to compare two indirect optical methods with a direct leaf mass-related approach of LAI estimation in tropical forests, (2) to detect elevational trends in LAI, stand leaf biomass and important leaf traits, and (3) to conduct a global meta-analysis of the elevational dependence of LAI and leaf mass in tropical mountains.

\subsection{METHODS}

\subsubsection{STUDY SITES}

Five forest stands at 1050, 1540, 1890, 2340 and $3060 \mathrm{~m}$ a.s.l. on the eastern slopes of the South Ecuadorian Andes, located east and west of the city of Loja at a maximum distance to each other of $30 \mathrm{~km}$, were selected for study (Fig. 2.1). Stands \#1 (1050 m) and $2(1540 \mathrm{~m})$ are located in the Sector Bombuscaro of Podocarpus National Park near the province capital of Zamora. Stands \#3 (1890 m) and $4(2340 \mathrm{~m})$ are situated in the "Reserva Biológica San Francisco" owned by the "Estación Científica San Francisco" (ECSF) south of the road 
from Loja to Zamora. Stand \#5 $(3060 \mathrm{~m})$ lies in the Sector Cajanuma of the National Park south of Loja. All study sites are situated on moderately steep slopes $\left(26\right.$ to $\left.31^{\circ}\right)$ facing northeast to northwest, except for stand \#2 which has a slope angle of only $10^{\circ}$. The five stands are representative examples of the characteristic altitudinal forest belts in this region, ranging from the lower montane to the upper montane zone as described by Balslev \& Øllgaard (2002) and Homeier et al. (2008). Stand \#5 is situated close to the tree line which occurs at unusually low elevation (about 3200 to $3400 \mathrm{~m}$ a.s.1.) in southern Ecuador. Patches of alpine paramo exist about $200 \mathrm{~m}$ upslope of this stand. The study plots $\left(400 \mathrm{~m}^{2}\right)$ were established in more or less homogenous parts of the forest stands where the canopies were closed. Visible human influence was low in the stands and withinplot gradients in soil conditions and topography were small.

The climate on the eastern slopes of the Ecuadorian Andes is mainly influenced by easterly winds which transport humid air masses from the Amazonian lowlands. These winds are prevailing during 10 to 11 months of a year, only disrupted by some weeks of westerly winds in the period between November and January. Mean annual air temperature inside the forest stands $(1.5 \mathrm{~m}$ above the forest floor) decrease linear with $5 \mathrm{~K} \mathrm{~km}^{-1}$ elevation along the transect (Table 1). Annual mean relative air humidity $(\mathrm{RH})$ at 1.5 $\mathrm{m}$ height inside the forest increased slightly. RH dropped to daily minima of $15 \%$ in the stands $\# 1$ and 3, but did not

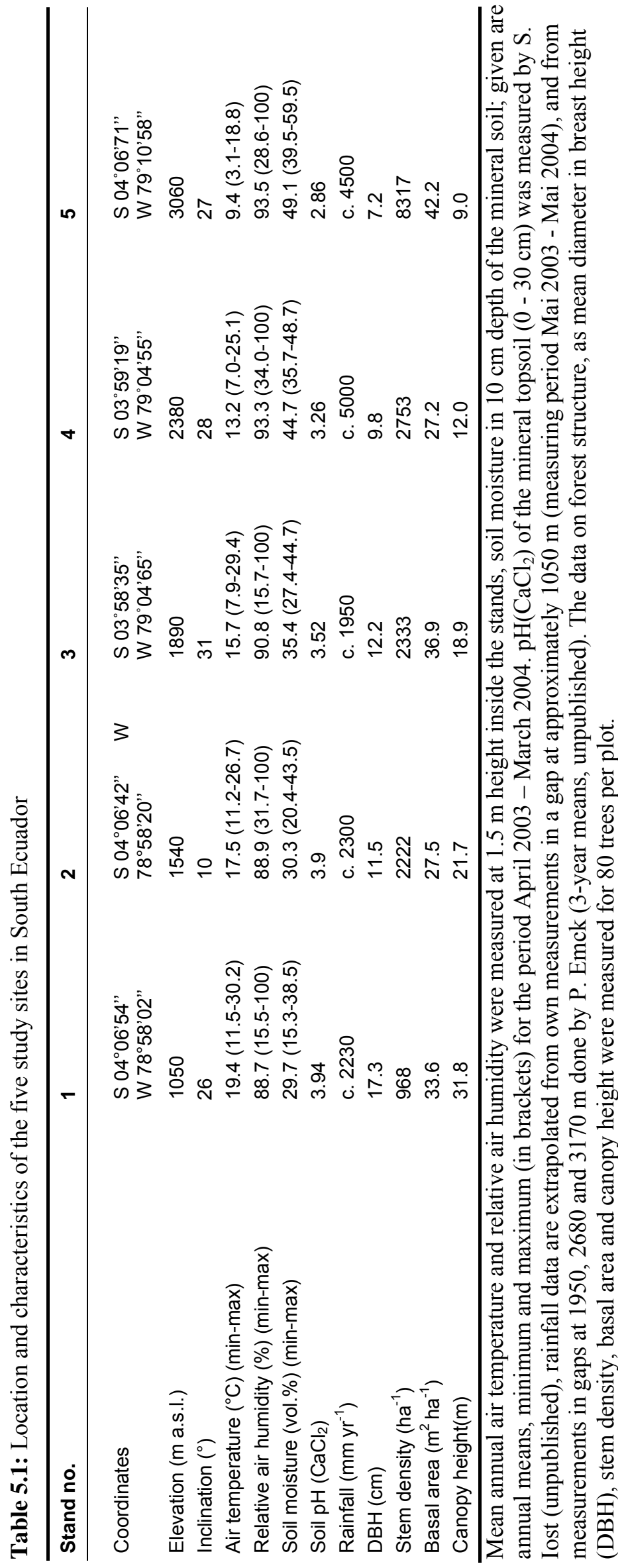


surpass $30 \%$ in the other three stands. Rainfall did not show a monotonous elevational trend; it varied around $2000 \mathrm{~mm} \mathrm{yr}^{-1}$ at the sites \#1 to 3, and reached peak values between 4500 and $5000 \mathrm{~mm} \mathrm{yr}^{-1}$ at the sites \#4 and 5 (P. Emck and M. Richter, unpublished data). In the months of November 2003 and January 2004, westerly winds caused dry and sunny weather at the eastern slopes of the study region, except for stand \#5 which experienced humid weather throughout. The longest dry period observed at the lower elevations were two weeks without rain in the first half of January 2004. The mean volumetric soil water content (10 cm of the mineral soil profile) in the period May 2003 to May 2004 increased upslope indicating the more frequent occurrence of water logging in the soils at higher elevation.

The soils of the stands \#1 and 2 developed from granodiorite, those of the stands \#3 to 5 from metamorphous shale, quarzite or sandstone. Despite this variability in geologic substrates, soil $\mathrm{pH}$ and $\mathrm{C} / \mathrm{N}$ ratio showed continuous changes along the slope pointing at a dominant influence of elevation and temperature on soil development. The $\mathrm{pH}\left(\mathrm{CaCl}_{2}\right)$ values of the mineral topsoil $(0-20 \mathrm{~cm})$ were low and decreased continuously with elevation, while the $\mathrm{C} / \mathrm{N}$ ratio $\left(\mathrm{L} / \mathrm{O}_{\mathrm{f}}\right)$ increased from 22 to 63 (S. Iost, in Wilcke et al. 2008). The ectorganic layer increased in depth from $48 \mathrm{~mm}$ at $1050 \mathrm{~m}$ to $430 \mathrm{~mm}$ at $3060 \mathrm{~m}$, indicating a 22-fold increase in organic matter atop of the mineral soil along the transect (data not shown). The soil profiles of the stands $\# 1$ and 2 were classified as Alumic Acrisols, those of stands 3 and 4 as Gleyic Cambisols, and the uppermost one as a Podzol (determination: S. Iost). Relevant climatic, edaphic and stand structural data of the study sites are given in Table 5.1.

From the lower montane to the upper montane forest sites a pronounced turnover of tree species and families occurs. Only one plant family, the Melastomataceae, was present at all five elevations. Most other families showed clear preferences in their altitudinal distribution, the Sapotaceae, Moraceae and Mimosaceae for the lowest parts, the Lauraceae, Euphorbiaceae and Clethraceae for mid-elevations and the Cunoniaceae, Podocarpaceae, Cyrillaceae, Rubiaceae and Aquifoliaceae for the uppermost sites.

In all five stands, only evergreen tree species were present. While average tree height decreased 3.5-fold along the transect, tree density increased. In contrast, cumulative basal area remained more or less constant over the transect (Tab.5.1).

\subsubsection{LEAF LITTER PRODUCTION, SPECIFIC LEAF AREA AND LEAF LIFESPAN}

We determined annual leaf litter production with 12 litter traps per plot using buckets equipped with $50 \times 50 \mathrm{~cm}$ sheets of gauze with $1 \mathrm{~mm}$-mesh width, positioned randomly within the $20 \times 20 \mathrm{~m}$ plots. The litter traps were emptied during the 1 -year measuring period every three weeks in the stands \#1 and 2, where decomposition rates were high, and every six weeks in the three other stands, starting on May 26, 2003. In the litter analysis, each two subsequent 3-week periods were added in the stands $\# 1$ and 2 to reach at 6-week periods which could be compared to the data of the other three stands. For estimating stand leaf biomass, annual leaf litter production and LAI, only the tree leaf fraction was considered. The small fractions of epiphyte leaves, leaves of understorey plants such as bamboo, and other components (e.g. flowers and fruits) were determined separately but not included in the analysis here.

All leaves collected in the litter traps (except for those from stand \#5) were scanned at 300 dpi with a flat bed scanner at ECSF, and the leaf area was determined with the WinFolia 2000a program (Régent Instruments, Quebec, Canada). Specific leaf area (SLA) was calculated by relating leaf area to dry weight $\left(48 \mathrm{~h}, 70^{\circ} \mathrm{C}\right)$. Since SLA showed no significant differences between the different sampling dates at any study site, we used the annual mean SLA value of a site for calculating leaf area from dry mass throughout the year. A somewhat different sampling protocol was developed for study site \#5 where 
Weinmannia loxensis Harling (Cunoniaceae) was the dominant tree species. This species has small pinnate leaves with the leaflets being shed individually. SLA and leaf dry mass were determined separately for this species and the data included in the stand mean by its relative mass proportion.

Table 5.2: Annual leaf litter production as measured with litter traps and stand averages of specific leaf area (SLA) and leaf lifespan in the five stands of the Ecuador transect.

\begin{tabular}{|c|c|c|c|c|c|}
\hline Stand no. & 1 & 2 & 3 & 4 & 5 \\
\hline $\begin{array}{l}\text { Leaf litter production } \\
\qquad\left(\mathrm{g} \mathrm{m}^{-2} \mathrm{yr}^{-1}\right)\end{array}$ & $505 \pm 33^{\mathrm{a}}$ & $502 \pm 35^{a}$ & $496 \pm 43^{a}$ & $266 \pm 22^{b}$ & $179 \pm 15^{\mathrm{c}}$ \\
\hline $\operatorname{SLA}\left(\mathrm{cm}^{2} \mathrm{~g}^{-1}\right)$ & $87.9 \pm 1.5^{\mathrm{a}}$ & $67.8 \pm 1.4^{\mathrm{b}}$ & $58.5 \pm 1.8^{c}$ & $52.7 \pm 1.8^{d}$ & $61.1 \pm 2.4^{\mathrm{C}}$ \\
\hline $\begin{array}{l}\text { Leaf lifespan } \\
\qquad \text { (months) (n) }\end{array}$ & $\begin{array}{l}16.2 \pm 2.6^{a} \\
(306)\end{array}$ & $\begin{array}{l}19.1 \pm 3.8^{\mathrm{ab}} \\
(316)\end{array}$ & $\begin{array}{l}23.6 \pm 2.3^{c} \\
(254)\end{array}$ & $\begin{array}{l}23.7 \pm 2.7^{b c} \\
(594)\end{array}$ & $\begin{array}{l}24.5 \pm 2.3^{\mathrm{C}} \\
(666)\end{array}$ \\
\hline
\end{tabular}

Given are means $\pm 1 \mathrm{SE}$ and the number of leaves observed for lifespan. Different letters indicate significant differences between study sites $(\mathrm{p}<0.05)$.

We assumed that leaf growth and leaf abscission occurred at similar rates in the study year, i.e. that leaf biomass was equal in May 2003 and in May 2004. This would imply that annual leaf litter production $\left(M_{1}\right)$ equalled annual leaf biomass production.

Leaf lifespan was recorded by establishing leaf survivorship curves for leaf populations of 10-15 trees per stand that were selected randomly in the plots. In all cases, small individuals ( 1.5 to $5 \mathrm{~m}$ high) of canopy tree species were selected since continuous access to the upper crown of large trees could not be provided. In the stands \#1 to 4, these trees were part of the second and lower canopy strata, whereas they formed the uppermost canopy layer in stand \#5. In May 2003, 24 twigs per plot were marked in these tree individuals. The total number of observed leaves ranged between 254 and 666 per stand (Tab.5.2). Every three to six weeks, the number of young, mature and dead leaves per twig marked was counted. The declining number of surviving leaves from the first census was then followed in leaf survivorship curves until the last leaf of this census was shed. In the stands \#3 to 5, the average lifespan of many leaves exceeded the observation period of 19 months. In these cases, the average leaf lifespan of the leaf population was obtained from linear extrapolation of the survivorship curves.

\subsubsection{LEAF AREA INDEX AND STAND LEAF BIOMASS}

In all five stands, we measured leaf area index (LAI) with a LAI-2000 canopy analyser system (Licor, Lincoln, Nebraska, USA) and additionally took digital hemispherical photographs for subsequent analysis with HemiView 2.1 software (Delta-T Devices, Cambridge, UK). The reference measurements with the LAI-2000 system were conducted either simultaneously over a grassland patch at a distance to the forest of 200-300 m (stands $\# 1$ and 2), or were taken immediately before and after the forest measurements in an open area within a $50 \mathrm{~m}$-distance from the forest (stands \#3 to 5).

All LAI-2000 measurements ( $\mathrm{n}=10$ per stand) and hemispherical photogaphs $(\mathrm{n}=12)$ were taken either before sunrise, after sunset or during uniform overcast sky conditions during daytime hours. The measurement locations were in direct vicinity of the litter traps at $1 \mathrm{~m}$ height. We took care that the canopy was dry during the LAI-2000 measurements and while taking the hemispherical photographs; otherwise, reflected light on wet surfaces would have led to an underestimation of LAI. The LAI-2000 sensor was positioned precisely in the 
horizontal plane during the measurements. In the analysis of the LAI-2000 data, we used only the three upper rings $\left(0-43^{\circ}\right.$ from zenith) of the hemispherical sensor, as recommended by Dufrêne \& Bréda (1995) for obtaining optimal LAI estimates with this system.

For hemispherical photography, a Nikon Coolpix digital camera with a $180^{\circ}$ fisheye lens was used. The camera was fixed in a self-levelling camera mount (type SLM5, Delta-T Devices) for guaranteeing horizontal orientation. The SLM5 system also provided markers for the horizon and north-south axis for assisting with image alignment.

To calculate the stand leaf biomass $\left(B_{1}\right.$ in $\left.\mathrm{g} \mathrm{m}^{-2}\right)$ of the study plots, two different equations were used:

$$
B_{1}=\text { LAI SLA }^{-1}
$$

and

$$
B_{1}=M_{1} \cdot D_{1}
$$

with $M_{1}$ being the annual leaf litter production (in $\mathrm{g} \mathrm{m}^{-2} \mathrm{yr}^{-1}$ ) and $D_{1}$ the average leaf lifespan (in yr). For solving equation (1), the LAI values derived from the LAI-2000 measurements were used. SLA in equation (1) refers to the measured stand mean of SLA. We combined our annual leaf litter data with the results on average SLA and mean leaf lifespan to calculate LAI independently from the two optical approaches of leaf area estimation:

$$
\mathrm{LAI}=M_{1} \text { SLA } D_{1}
$$

Thus, stand leaf biomass was calculated with two, LAI with three independent approaches which allowed a comparison of optical and leaf mass-related techniques in the five forest stands.

\subsubsection{A META-ANALYSIS OF THE ELEVATION DEPENDENCE OF LAI AND STAND LEAF BIOMASS IN TROPICAL FORESTS}

For analysing the elevation dependence of leaf mass and area in tropical mountains on a broader scale, we searched the literature for data on LAI and $B_{1}$ in the relevant forest types. This analysis helped us to partly overcome the methodological shortcomings of the transect study in which a replication on the plot level was not possible due to the enormous labour effort needed. The data set of the meta-analysis consisted of 12 studies in 39 forest stands from the Neo- and Paleotropics spanning lower montane $(>800 \mathrm{~m})$ to upper montane stands (up to $3060 \mathrm{~m}$ ). Included were data from both transect and single-plot studies which applied a diversity of optical or leaf mass-related methods. Lowland stands $<800 \mathrm{~m}$ were only included if they were part of a transect study.

\subsubsection{STATISTICAL ANALYSIS}

Linear regression analyses were applied to identify significant relationships between elevation and LAI, stand leaf biomass, leaf litter production, SLA or leaf lifespan. Separate analyses were conducted for the LAI and stand leaf biomass estimates obtained with optical or mass-related approaches. In addition, LAI and leaf biomass were regressed on elevation for the pan-tropic data set, again applying separate regressions for the different approaches. All regressions were calculated using Xact software (version 7.12; SciLab, Hamburg, Germany). To test for significant differences in LAI, stand leaf biomass, leaf litter production, SLA or leaf lifespan among the five Ecuadorian stands, non-parametric analyses of variance (Kruskal-Wallis test) and subsequent Mann-Whitney two-sample tests 
(Wilcoxon U-test) were conducted using SAS software (version 8.2; SAS Institute, Cary, North Carolina, USA).

\subsection{RESULTS}

\subsubsection{SLA AND LEAF LIFESPAN IN THE ECUADOR TRANSECT}

The stand average of SLA declined significantly from stand \#1 to stand \#4, but was higher again in the uppermost stand (Tab.5.2). The apparent increase from stand \#4 to \#5 was primarily caused by the high SLA value of the dominant tree species Weinmannia loxensis in the uppermost stand which had pinnate and particularly thin leaves. Average leaf lifespan increased significantly from stand $\# 1$ to $\# 3$, and remained more or less constant further upslope (Tab.5.2). The dependence of leaf lifespan on elevation was significant at $\mathrm{p}<0.05$ (Tab.5.3).

Table 5.3: Results of linear regression analyses of leaf litter production, LAI, stand leaf biomass, SLA and leaf lifespan on elevation and various parameters related to leaf area

\begin{tabular}{|c|c|c|c|c|}
\hline Parameter & Source & Regression equation & $r^{2}$ & $\mathbf{p}$ \\
\hline \multirow[t]{3}{*}{ Leaf litter production } & Elevation & $y=7.60-0.002 \cdot x$ & 0.85 & 0.013 \\
\hline & SLA & $y=-0.22+0.06 \cdot x$ & 0.30 & 0.172 \\
\hline & Leaf lifespan & $y=10.41-0.30 \cdot x$ & 0.49 & 0.096 \\
\hline \multicolumn{5}{|l|}{ LAl } \\
\hline \multirow[t]{4}{*}{ LAI 2000} & Elevation & $y=6.2-0.001 \cdot x$ & 0.97 & 0.001 \\
\hline & Leaf litter production & $y=2.22+0.47 x$ & 0.72 & 0.033 \\
\hline & SLA & $y=0.73+0.05 \cdot x$ & 0.64 & 0.052 \\
\hline & Leaf lifespan & $y=8.92-0.23 \cdot x$ & 0.91 & 0.006 \\
\hline \multirow[t]{4}{*}{ Hemispherical photography } & Elevation & $y=3.4-0.0003 \cdot x$ & 0.61 & 0.060 \\
\hline & Leaf litter production & $y=2.01+0.19 \cdot x$ & 0.79 & 0.020 \\
\hline & SLA & $y=2.473+0.004 \cdot x$ & 0.03 & 0.390 \\
\hline & Leaf lifespan & $y=3.61-0.04 \cdot x$ & 0.20 & 0.229 \\
\hline Leaf litter fall + lifespan + SLA & Elevation & $y=8.6-0.002 x$ & 0.84 & 0.013 \\
\hline \multicolumn{5}{|l|}{ Stand leaf biomass } \\
\hline \multirow[t]{4}{*}{ LAI $2000+$ SLA } & Elevation & $y=719-0.05 \cdot x$ & 0.20 & 0.229 \\
\hline & Leaf litter production & $y=508.9+28.3 \cdot x$ & 0.26 & 0.192 \\
\hline & SLA & $y=726.8-1.64 \cdot x$ & 0.06 & 0.340 \\
\hline & Leaf lifespan & $y=677.0-2.69 \cdot x$ & 0.01 & 0.427 \\
\hline \multirow[t]{2}{*}{ Leaf litter fall + lifespan } & Elevation & $y=1070-0.202 \cdot x$ & 0.44 & 0.112 \\
\hline & SLA & $y=523.75+2.22 \cdot x$ & 0.01 & 0.415 \\
\hline \multirow[t]{2}{*}{ SLA } & Elevation & $y=91.4-0.013 \cdot x$ & 0.55 & 0.077 \\
\hline & Leaf lifespan & $y=140.13-3.48^{\cdot} x$ & 0.85 & 0.013 \\
\hline Leaf lifespan & Elevation & $y=13.2+0.004 \cdot x$ & 0.79 & 0.021 \\
\hline
\end{tabular}

Different regressions were calculated for the three alternative approaches of estimating LAI and the two approaches of estimating stand leaf biomass. Significant relationships $(\mathrm{p}<0.05)$ are printed in bold. 


\subsubsection{STAND LEAF BIOMASS AND LAI IN THE ECUADOR TRANSECT}

No elevational trend of annual leaf litter production $\left(M_{1}\right)$ was visible between stands \#1 and \#3. Further upslope, however, $M_{1}$ decreased to about a third in stand \#5 (Tab.5.2). The negative relationship between $M_{1}$ and elevation was significant not only for the upper slope but for the entire transect as well (1050 to $3060 \mathrm{~m}$, Tab.5.3). A similar dependence on elevation would hold for annual leaf biomass production, if leaf production and leaf shedding were equivalent in their annual rates as we assumed.

Table 5.4: Leaf area index (LAI) estimates for the five stands of the Ecuador transect as obtained with three different approaches.

\begin{tabular}{|c|c|c|c|c|c|}
\hline Stand no. & 1 & 2 & 3 & 4 & 5 \\
\hline \multicolumn{6}{|l|}{$\mathrm{LAI}\left(\mathrm{m}^{2} \mathrm{~m}^{-2}\right)$} \\
\hline LAI-2000 & $5.1 \pm 0.1^{\mathrm{aA}}$ & $4.6 \pm 0.1^{\mathrm{bA}}$ & $3.9 \pm 0.2^{\mathrm{cA}}$ & $3.6 \pm 0.1^{\mathrm{cA}}$ & $2.9 \pm 0.3^{\mathrm{dA}}$ \\
\hline Hemispherical photography & $2.8 \pm 0.2^{\mathrm{aB}}$ & $3.0 \pm 0.3^{\mathrm{aB}}$ & $3.0 \pm 0.3^{\mathrm{aA}}$ & $2.7 \pm 0.1^{\mathrm{aB}}$ & $2.2 \pm 0.2^{\mathrm{bA}}$ \\
\hline Leaf litter production + leaf lifespan + SLA data & $6.0 \pm 0.4^{\mathrm{aA}}$ & $5.4 \pm 0.4^{\mathrm{aA}}$ & $5.7 \pm 0.5^{\mathrm{aB}}$ & $2.8 \pm 0.2^{\mathrm{bB}}$ & $2.2 \pm 0.2^{\mathrm{cA}}$ \\
\hline
\end{tabular}

Given are means $\pm 1 \mathrm{SE}$; different small letters indicate significant differences between the five stands, different capitals indicate significant differences between the three approaches for a given stand.

The three different approaches for estimating LAI showed only partial agreement along the transect. The LAI estimate obtained from the LAI-2000 measurements decreased linearly (Tab.5.4) with all differences between the stands being significant, except for the stands \#3 and 4 which had similar LAI-2000 values. LAI estimation with hemispherical photography gave, in general, lower values than the LAI-2000 measurement. The discrepancy between the two optical methods was particularly large at lower elevation $(<2000 \mathrm{~m})$. Hemispherical photography yielded no significant differences in LAI between any of the stands \#1 to 4 (Tab.5.4). Finally, the results from the mass-related calculation, based on leaf litter production, leaf lifespan and SLA, were much closer to the LAI-2000 data than those from hemispherical photography. In agreement with this observation, a significant dependence on elevation was only found for these two approaches but not for hemispherical photography. The leaf mass-related approach resulted in similar high values for the stands \#1 to 3 (differences not significant), and showed a steep decrease further upslope (Tab.5.4).

The three approaches for estimating LAI agreed only in the uppermost stand (\#5). Besides the very low values obtained by hemispherical photography on the lower slope, there was a general tendency of the mass-related approach for giving the highest values of all approaches at lower elevations $(<2000 \mathrm{~m})$, and a tendency of the LAI-2000 method for doing so at the upper elevations $(>2000 \mathrm{~m})$.

Stand leaf biomass $\left(B_{1}\right)$ as calculated from SLA and LAI data (LAI-2000 estimates) peaked in the stands \#2 to $4(1540$ to $2380 \mathrm{~m})$; significantly smaller leaf biomasses were obtained for stand \#1 and particularly for stand $\# 5$ (Tab.5.5). $B_{1}$ calculated with the litter production and leaf lifespan data at $1890 \mathrm{~m}$ (stand \#3) gave significantly higher values compared to the calculation based on SLA and LAI-2000 data; this is a consequence of the comparably low LAI estimate obtained for this stand with the LAI-2000 canopy analyzer (Tab.5.4). None of the two calculation methods showed a significant dependence of $B_{1}$ on elevation along the entire transect. Furthermore, neither SLA nor leaf lifespan were significant predictors of $B_{1}$ in the Ecuador transect (Tab.5.3). 
Table 5.5: Estimates of stand leaf biomass for the five stands as obtained with two different approaches.

\begin{tabular}{|c|c|c|c|c|}
\hline Stand No. & Approach & 1 & 3 & 5 \\
\hline Stand leaf & LAI $2000+$ SLA & $584.8 \pm 12.9^{\mathrm{aA}} 681.5 \pm 7.3^{\mathrm{bA}}$ & $660.4 \pm 25.6^{\mathrm{bA}}$ & $689.5 \pm 17.0^{\mathrm{bA}} 481.3 \pm 41.9^{\mathrm{aA}}$ \\
\hline biomass $\left(\mathrm{g} \mathrm{m}^{-2}\right)$ & $\begin{array}{l}\text { Leaf litter production } \\
\text { + leaf lifespan data }\end{array}$ & $682.3 \pm 44.7^{\mathrm{aA}} 799.0 \pm 5.4^{\mathrm{bA}}$ & $974.3 \pm 83.7^{\mathrm{bB}}$ & $525.3 \pm 43.8^{\mathrm{cB}} 364.7 \pm 29.5^{\mathrm{dA}}$ \\
\hline
\end{tabular}

Given are means $\pm 1 \mathrm{SE}$; different small letters indicate significant differences between the five stands, different capitals indicate significant differences between the three approaches for a given stand.

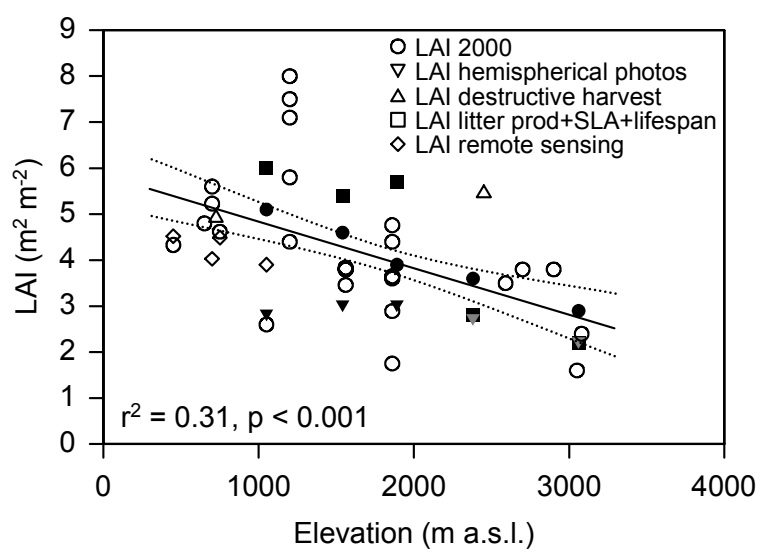

Figure 5.1: Dependence of LAI on elevation for 49 tropical moist forests $(y=5.85-0.001 \cdot x)$ according to a meta-analysis of data in 12 studies along elevational transects or singleplot studies in the Paleo- and Neotropics (Edwards \& Grubb 1977, Grubb 1977, Herbert \& Fownes 1999, Kitayama \& Aiba 2002, Kitayama et al. 2004, Köhler 2002, Odum 1970, Quinones-Orfila 1997 cited in Wang et al. 2003, Takyu et al. 2003, Wang et al. 2003, Weaver \& Murphy 1990; filled symbols indicate data from the present study). The LAI data were obtained with five different approaches. Doted lines indicate the $95 \%$ confidence intervals based on the predicted mean from the regression line.

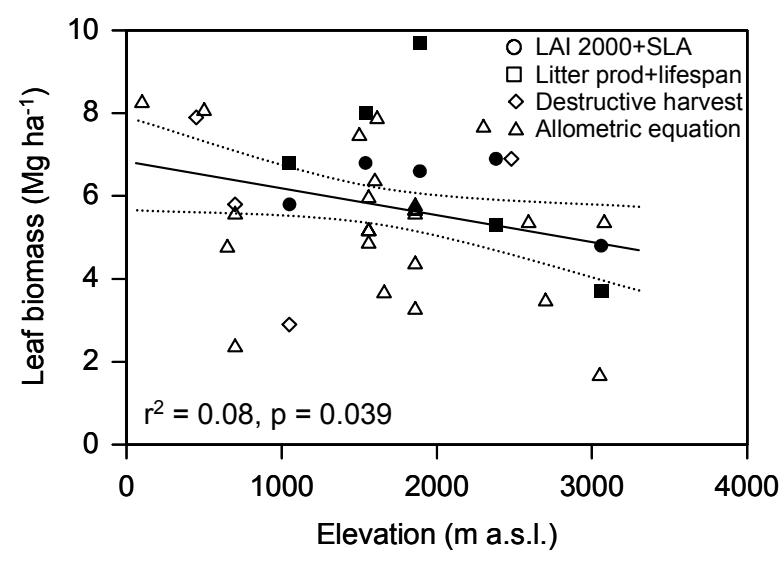

Figure 5.2: Dependence of stand leaf biomass on elevation $(\mathrm{y}=6.84-0.006 \cdot \mathrm{x})$ for 38 tropical moist forests according to a meta-analysis of data in 12 studies along elevational transects or single-plot studies in the Paleo- and Neotropics (Brun 1976, Edwards \& Grubb 1977, Frangi \& Lugo 1985, Kitayama \& Aiba 2002, Odum 1970, Ovington \& Olson 1970 in Weaver \& Murphy 1990 , Raich et al. 1997, Takyu et al. 2003, Tanner from Grubb 1977, Tanner 1980, Weaver \& Murphy 1990; filled symbols indicate data from the present study). The LAI data were obtained with four different approaches. Doted lines indicate the 95\% confidence intervals based on the predicted mean from the regression line.

\subsubsection{A META-ANALYSIS OF LEAF AREA INDEX AND STAND LEAF BIOMASS DATA FROM TROPICAL MOUNTAINS AROUND THE GLOBE}

The survey of literature data on the LAI of tropical montane forests, which included 12 studies with 39 stands and covered five different approaches ( 2 optical, 2 leaf mass-related, 1 based on remote sensing) resulting in 49 data points, showed a highly significant LAI decrease from $1000 \mathrm{~m}$ to $3000 \mathrm{~m}$ (Fig.5.1). Thus, the mean trend line indicates a decrease by $1 \mathrm{~m}^{2} \mathrm{~m}^{-2} \mathrm{~km}^{-1}$. An even closer negative relationship between LAI and elevation appeared when the LAI-2000 data were analysed separately. 
The pan-tropical data on stand leaf biomass $(n=38)$ revealed a decrease in $B_{1}$ with increasing elevation as well (Fig.5.2). However, the decrease in $B_{1}$ was less pronounced than in the case of LAI and the $B_{1}$ data showed a higher variability among the stands than the LAI data.

\subsection{DisCUSSION}

\subsubsection{LEAF AREA DETERMINATION IN TROPICAL FORESTS - DIRECT VS. INDIRECT METHODS}

The two indirect optical methods of LAI estimation being applied in the present study, i.e. LAI-2000 canopy analyser and hemispherical photography, do not exactly measure LAI but register all canopy elements which intercept radiation including branches, stems, fruits and epiphytes. Therefore, various authors using optical methods preferred terms such as "vegetation area index" (VAI) (Fassnacht et al. 1994), "plant area index" (PAI) (Bréda 2003, Neumann et al. 1989), "foliage area index" (FAI) (Welles \& Norman 1991), or "effective leaf area index" $\left(\mathrm{L}_{\mathrm{e}}\right)$ (Chen \& Black 1992, Jonckheere et al. 2004).

In tropical montane forests, the role in particular of stems, branches and epiphytes has to be considered when applying optical methods of canopy analysis. The density of stems and, thus, the cumulative surface area of non-leaf elements significantly increased with elevation along the Ecuador transect, resulting in a larger difference between plant area index and LAI in the high-elevation stands. In contrast, this effect should be comparably small in forests at lower elevation with high LAI. Therefore, high-elevation forests with a high density of stems and branches may be subject to an overestimation of leaf area by optical methods. On the other hand, the LAI of tropical lower montane and lowland forests may be underestimated by these methods because optical approaches were found to be subject of saturation effects leading to a significant underestimation of LAIs greater than 5 or 6 (Chason et al. 1991, Dufrêne \& Bréda 1995, Fassnacht et al. 1994, Mussche et al. 2001). One reason for this error is non-random distribution of foliar elements in the canopy, which may account for an error of $25-50 \%$ in the LAI estimate (Bréda 2003). To overcome the problems associated with leaf clumping in complex canopies, Chen et al. (1997) recommended combining LAI-2000 measurements at several zenith angles with an estimation of the clumping index obtained with the TRAC (Tracing Radiation and Architecture of Canopies) instrument ( $3^{\text {rd }}$ Wave Engineering, Ontario, Canada). However, the application of this combined approach for tropical rainforest canopies has not been tested against leaf mass-related measurements so far. In any case, the known biases of optical methods in canopies with frequent leaf clumping as in tropical forests must be viewed as support for the comparably high LAI values that were obtained with the massrelated approach in the lower montane stands of the Ecuador transect.

The second optical method applied in the present study, i.e. hemispherical photography, is known to show similar problems as the LAI-2000 method, resulting in an underestimation of high LAI values and an overestimation of small ones (Mussche et al. 2001). In the Ecuador transect, this method gave lower values in all five stands than the other approaches. Moreover, the results of hemispherical photography were highly unrealistic because they indicate no altitudinal trend of LAI in the transect which contradicts the leaf litter data.

Inoue et al. (2004) showed that image size and camera type affect the light environment analysis in this approach. According to van Gardingen et al. (1999), conventional analysis of hemispherical photographs results in an underestimation of LAI of up to $50 \%$ compared to harvest methods. Accordingly, this error can be reduced by the segment analysis (logaverage) method to $15 \%$. Since we used the Hemiview software based on a conventional data analysis, the failure of hemispherical photography in our study is partly explicable. In 
agreement with our results, Asner et al. (2003) found in his global survey of LAI data that leaf mass-related approaches yielded higher LAI values for tropical evergreen forests than optical methods. In their analysis, the LAI-2000 system was also closer to mass-related approaches than other optical methods.

Among the direct methods of LAI measurement, leaf area determination in harvested trees has only rarely been applied in tropical forests because it is so labour-intensive (McWilliam et al. 1993). LAI estimation from litter trapping may suffer from a highly variable leaf lifespan in tropical moist forests, ranging from less than 12 mo to about 6 years (Asner et al. 2003). This source of error can only be overcome by combining litter trapping with an indepth analysis of average leaf longevity in the respective stands. Such an approach was adopted here; it gives an estimate not only of LAI, but also of stand leaf biomass.

Litter sampling in tropical forests must underestimate leaf production, because a substantial proportion of the leaves is consumed by leaf herbivores in the canopy, and part of the senescent leaves are decomposed in the crowns prior to leaf fall. For example, Clark et al. (2001) estimated leaf herbivory in tropical lowland forests to account for about $12 \%$ of measured litter fall. We expect that this loss term should decrease with elevation in the Ecuador transect since leaf litter at high elevations showed less signs of herbivory and the canopy structure of high elevation stands offers fewer sites for leaf litter to be trapped and decomposed in situ.

A second source of error in the leaf mass-related approach may be associated with our technique of measuring average leaf lifespan. Kikuzawa (1989) and Lowman (1992) observed that leaf lifespan increases from the uppermost canopy to lower canopy and understorey leaves in tropical moist forests. Since we observed the survivorship of leaves mainly in the second and lower canopy strata, our stand averages of lifespan may be different from that of the entire leaf population with a possible tendency to overestimate $D_{1}$ in the lowermost stands with large tree height. We attempted to minimize errors caused by different canopy positions by observing a very high number of leaves under a similar radiation climate. Moreover, we assume that our leaf mass-related approach should have underestimated leaf litter production in the stands \#1-3, while it may have overestimated leaf lifespan in the same stands with the consequence that both sources of error should partly compensate each other when LAI is calculated.

Based on this assessment of errors associated with the different approaches, it appears that LAI measurement across environmental gradients should preferably use leaf mass-related approaches combined with a thorough leaf lifespan analysis because structurally different forest types are to be considered. Optical methods should be applied only in studies where forests with a similar canopy structure are to be compared.

\subsubsection{ELEVATIONAL CHANGE IN LEAF BIOMASS AND LEAF AREA, AND ITS ECOLOGICAL IMPLICATIONS}

Our estimates of stand leaf biomass at lower to mid-montane elevation (stands \#1-3: 6.89.7 $\mathrm{Mg} \mathrm{ha}^{-1}$ according to the leaf mass-related approach) are comparable to the mean $B_{1}$ value given by Raich et al. (1997) for tropical montane forests $\left(8.1 \mathrm{Mg} \mathrm{ha}^{-1}\right)$. However, our data are also in the range of leaf biomass values reported from tropical lowland forests (6.310.8 $\mathrm{Mg} \mathrm{ha}^{-1}$, McWilliam et al. 1993) indicating that the difference in $B_{1}$ between lowland and montane stands is small. The low $B_{1}$ value from the uppermost stand in Ecuador points to a leaf mass decrease only in the uppermost section of the transect. This conclusion is supported by the regression analysis of stand leaf biomass on elevation which revealed no significant relationship neither for the leaf mass-related nor the LAI-2000 estimate. This result contrasts with a decreasing leaf biomass along an elevation transect (290-1660 m a.s.l) on young lava flows in Hawaii (Raich et al. 1997), and on ultrabasic bedrock on Mt. 
Kinabalu, Malaysia (Kitayama \& Aiba 2002). However, a second transect on sedimentary soils on Mt. Kinabalu showed a slight increase of $B_{1}$ with elevation supporting the view that the leaf biomass difference between lowland and montane forests is generally small (Tanner 1980).

According to Medina \& Klinge (1983), the annual leaf litter production $\left(M_{1}\right)$ of tropical montane forests is generally higher than that of tropical moist lowland forests (3.9-6.4 vs. 5.3-8.2 $\left.\mathrm{Mg} \mathrm{ha}^{-1} \mathrm{yr}^{-1}\right)$. These results compare well with our data which showed a litter production of $5.0 \mathrm{Mg} \mathrm{ha}^{-1} \mathrm{yr}^{-1}$ for the lower and mid-montane stands (\#1-3) but a sharp decrease higher upslope at elevations $>2000 \mathrm{~m}$ (stands \#4 and 5). In an elevational transect study in tropical moist forests in Hawaii, $M_{1}$ decreased with elevation from 290 to $1660 \mathrm{~m}$ (Raich et al. 1997).

Although specific leaf area is highly dependent on species, the stand average of SLA tends to decrease with elevation in tropical montanes. For example, Medina \& Klinge (1983) reported an SLA value of $83 \mathrm{~cm}^{2} \mathrm{~g}^{-1}$ for a tropical montane forest in Puerto Rico compared to $47 \mathrm{~cm}^{2} \mathrm{~g}^{-1}$ in an elfin forest higher upslope. In contrast, tropical lowland moist forests have average SLA values in the range of 65 to $93 \mathrm{~cm}^{2} \mathrm{~g}^{-1}$ (McWilliam et al. 1993, Medina \& Klinge 1983).

In the Ecuador transect, specific leaf area decreased from $88 \mathrm{~cm}^{2} \mathrm{~g}^{-1}$ at $1050 \mathrm{~m}$ to $53 \mathrm{~cm}^{2}$ $\mathrm{g}^{-1}$ at $2350 \mathrm{~m}$ while it seemed to increase again further upslope toward the uppermost stand $\left(61 \mathrm{~cm}^{2} \mathrm{~g}^{-1}\right)$. This picture changes if the high SLA value of the most abundant tree species, Weinmannia loxensis with pinnate leaves $\left(87 \mathrm{~cm}^{2} \mathrm{~g}^{-1}\right)$, that are atypical for this elevation, is omitted from the analyis: the mean SLA of stand \#5 would then be much lower $\left(57 \mathrm{~cm}^{2} \mathrm{~g}^{-1}\right)$, supporting the general negative trend of SLA with elevation. Thus, despite a large species effect on leaf morphology, it is evident that SLA shows a much steeper decrease with elevation than annual leaf litter production (and annual leaf biomass production) or stand leaf biomass.

LAI decreased significantly with elevation in the Ecuador transect according to both the leaf mass-related and the LAI-2000 estimate. This observation compares well with the results of our pan-tropical meta-analysis from tropical montane forests where the regression line based on 49 stands indicates a mean LAI of $4.9 \mathrm{~m}^{2} \mathrm{~m}^{-2}$ at $1000 \mathrm{~m}$ and a decrease further upslope by about $1 \mathrm{~m}^{2} \mathrm{~m}^{-2} \mathrm{~km}^{-1}$. Since the majority of data points were obtained by LAI2000 measurements, one may assume from the specific errors associated with this method, that the LAI decrease with elevation is even steeper than indicated by the data.

A decrease in LAI must have important implications for the prediction of forest productivity along tropical mountain slopes: since canopy carbon gain is closely linked to the amount of intercepted radiation, a marked reduction in LAI must cause a substantial decline in net primary production with increasing elevation, independently from any possible negative effect of lowered temperatures or nutrient shortage on canopy carbon gain.

Besides a reduced leaf area, a reduction in foliar nitrogen content may be another factor that could lead to a lowered photosynthetic carbon gain in high-elevation forests. In the Ecuador transect, the foliar C/N ratio greatly decreased from 1050 to $3060 \mathrm{~m}$ while, due to a substantial reduction in SLA, foliar $\mathrm{N}$ (nitrogen) content per unit leaf area did not (M. Unger, unpublished). Even though data on photosynthetic capacity are not available from this transect, it can be concluded that a $40 \%$ reduction in LAI must represent the principal factor controlling elevational changes in canopy carbon gain, whereas the decrease in foliar $\mathrm{N}$ content will be of secondary importance because it is more or less compensated by a larger leaf thickness. 


\subsection{CONCLUSIONS}

Key factors for understanding the elevational change in leaf area in the Ecuador transect are a substantial decrease in SLA in upslope direction and a concomitant increase in leaf lifespan, two leaf traits with a strong negative correlation to each other in our five-stand sample. Leaves with a relatively high SLA as existing at the lower elevations of the transect are generally thought to have a higher $\mathrm{C}$ (carbon) assimilation rate, but a shorter lifespan and a higher vulnerability to herbivory compared to leaves with a lower SLA (Chabot \& Hicks 1982, Coley et al. 1985, Grime et al. 1996, Poorter \& van der Werf 1998). From the perspective of resource economy, leaves with a high SLA should perform best in resourcerich environments, while low-SLA leaves would be advantageous under resource-poor conditions where retention of captured resources becomes a higher priority (Wilson et al. 1999). This concept applied to the Ecuador transect implies that resource limitation must increase with elevation. Indeed, we showed in a previous study that $\mathrm{N}$ becomes increasingly unavailable towards higher elevations in this transect (Leuschner et al. 2007) suggesting a key role of $\mathrm{N}$ supply in the observed decrease of SLA. The fact, that stand leaf biomass (which is directly related to carbon investment into leaf biomass) showed no significant change along the slope while foliar $\mathrm{N}$ content decreased, suggests that $\mathrm{N}$ limitation is also the principal factor that causes the reduction in LAI with elevation.

We conclude that substantial evidence exists for a causal relationship between reduced soil $\mathrm{N}$ supply, as caused by low temperature and oxygen deficiency effects in water-logged soils, and a lowered SLA and LAI in montane and upper montane forests in South Ecuador. Ultimately, $\mathrm{N}$ shortage would result in a reduced carbon gain of high-elevation forests, thereby partly explaining the large decrease in tree height and aboveground forest biomass with elevation in this tropical mountain transect.

\subsection{ACKNOWLEDGEMENTS}

We thank P. Emck and M. Richter (University of Erlangen) for supplying the rainfall data and S. Iost \& F. Makeschin (University of Dresden) for providing the $\mathrm{pH}$ and soil $\mathrm{C} / \mathrm{N}$ ratio data. We are also grateful to M. Unger (University of Göttingen) for data on SLA, leaf chemistry and radiation and to J. Homeier (University of Göttingen) for support in taking hemispherical photographs. Further, we want to thank M. Küppers, (University of Hohenheim) who provided a second LAI-2000 instrument. We gratefully acknowledge the financial support offered by DFG (Germain Science Foundation) through a grant in the Research Unit 402 (Functionality in a Tropical Mountain Forest, subproject B8). We thank the Ministerio del Ambiente Loja-Zamora for granting a research permit, and the Fundación Científica San Francisco (Nature and Culture International) for the ongoing support at Estación Científica San Francisco.

\subsection{REFERENCES}

Asner, G.P., Scurlock, J.M.O., Hicke, J.A. 2003. Global synthesis of leaf area index observations: implications for ecological and remote sensing studies. Global Ecology and Biogeography 12: 191-205.

Balslev, H., Øllgaard, B. 2002. Mapa de vegetación del sur de Ecuador. In: Aguirre, Z.M., Madsen, J.E., Cotton, E., Balslev, H., (eds.). Botánica Austroecuatoriana - Estudios sobre los recursos vegetales en las provincias de el Oro, Loja y Zamora-Chinchipe. Quito: Ediciones ABYA YALA, pp. 51-64. 
Barclay, H.J., Trofymow, J.A. 2000. Relationship of readings from the Li-Cor canopy analyser to total one-sided leaf area index and stand structure in immature Douglas-fir. Agricultural and Forest Meteorology 132: 121-126.

Bréda, N.J.J. 2003. Ground-based measurements of leaf area index: a review of methods, instruments and current controversies. Journal of Experimental Botany 54: 2403-2417.

Brun, R. 1976. Methodik und Ergebnisse zur Biomassenbestimmung eines NebelwaldÖkosystems in den Venezolanischen Anden. Oslo: Proceedings Division I, 16th IUFRO World Congress. pp. 490-499

Chabot, B.F., Hicks, D.H. 1982. The ecology of leaf life span. Annual Review of Ecology and Systematics 13: 229-259.

Chason, J., Baldocchi, D., Hutson, M. 1991. A comparison of direct and indirect methods for estimating forest leaf area. Agricultural and Forest Meteorology 57: 107-128.

Chen, J.M., Black, T.A. 1992. Defining leaf-area index for non-flat leaves. Plant, Cell Environment 15: 421-429.

Chen, J.M., Rich, P.M., Gower, S.T., Norman, J.M., Plummer, S. 1997. Leaf area index of boreal forests: theory, techniques, and measurements. Journal of Geophysical Research 102: 29429-29443.

Clark, D.A., Brown, S., Kicklighter, D.W., Chambers, J.Q., Thomlinson, J.R., Ni, J. 2001. Measuring net primary production in forests: concepts and field methods. Ecological Applications 11: 356-370.

Coley, P.D., Bryant, J.P., Chapin, F.S. 1985. Resource availability and plant anti-herbivore defense. Science 230: 895-899.

Comeau, P., Gendron, F., Letchford, T. 1998. A comparison of several methods for estimating light under a paper birch mixedwood stand. Canadian Journal of Forest Research 28: 1843-1850.

Dufrêne, E., Bréda, N. 1995. Estimation of deciduous forest leaf-area index using direct and indirect methods. Oecologia 104: 156-162.

Edwards, P.J., Grubb, P.J. 1977. Studies of mineral cycling in a montane rain forest in New Guinea I. The distribution of organic matter in the vegetation and soil. Journal of Ecology 65: 934-969.

Fassnacht, K.S., Gower, S.T., Norman, J.M., McMurtrie, R.E. 1994. A comparison of optical and direct-methods for estimating foliage surface-area index in forests. Agricultural and Forest Meteorology 71: 183-207.

Frangi, J.L., Lugo, A.E. 1985. Ecosystems dynamics of a sub-tropical floodplain. Ecological Monographs 55: 351-369.

Gower, S.T., Kucharik, C.J., Norman, J.M. 1999. Direct and indirect estimation of leaf area index, fAPAR, and net primary production of terrestrial ecosystems. Remote Sensing of Environment 70: 29-51.

Grime, J.P., Cornelissen, J.H.C., Thompson, K., Hodgson, J.G. 1996. Evidence of a causal connection between anti-herbivore defence and the decomposition rate of leaves. Oikos 77: 489-494.

Grubb, P.J. 1977. Control of forest growth and distribution on wet tropical mountains: with special reference to mineral nutrition. Annual Review of Ecological Systems 8: 83-107.

Herbert, D.A., Fownes, J.H. 1999. Forest productivity and efficiency of resource use across a chronosequence of tropical montane soils. Ecosystems 2: 242-254.

Homeier, J., Werner, F.W., Breckle, S.W., Richter, M. 2008. Potential vegetation and floristic composition of Andean forests in South Ecuador, with a focus on the reserve San Francisco. In: Beck, E., Bendix, J., Kottke, I., Makeschin, F., Mosandl, R., (eds.). Gradients in a tropical mountain ecosystem in Ecuador. Springer-Verlag Berlin, Ecological Studies 198, in press. 
Inoue, A., Yamamoto, K., Mizoue, N., Kawahara, Y. 2004. Effects of image quality, size and camera type on forest light environment estimates using digital hemispherical photography. Agricultural and Forest Meteorology 126: 89-97.

Jonckheere, I., Fleck, S., Nackaerts, K., Muys, B., Coppin, P., Weiss, M., Baret, F. 2004. Review of methods for in situ leaf area index determination - Part I. Theories, sensors and hemispherical photography. Agricultural and Forest Meteorology 121: 19-35.

Kikuzawa, K. 1989. Ecology and evolution of phenological pattern, leaf longevity and leaf habit. Evolutionary Trends of Plants 3: 105-110.

Kitayama, K., Aiba, S.-I. 2002. Ecosystem structure and productivity of tropical rain forests along altitudinal gradients with contrasting soil phosphorus pools on Mount Kinabalu, Borneo. Journal of Ecology 90: 37-51.

Kitayama, K., Aiba, S.-I., Takyu, M., Majalap, N., Wagai, R. 2004. Soil phosphorus fractionation and phosphorus-use efficiency of a Bornean tropical montane rain forest during soil aging with podzolization. Ecosystems 7: 259-274.

Köhler, L. 2002. Die Bedeutung der Epiphyten im ökosystemaren Wasser- und Nährstoffumsatz verschiedener Altersstadien eines Bergregenwaldes in Costa Rica. Dissertation, University Göttingen, pp. 131.

Küßner, R., Mosandl, R. 2000. Comparison of direct and indirect estimation of leaf area index in mature Norway spruce stands of eastern Germany. Canadian Journal of Forest Research 30: 440-447.

Leuschner, Ch., Moser, G., Bertsch, C., Röderstein, M., Hertel, D. 2007. Large altitudinal increase in tree root/shoot ratio in tropical mountain forests of Ecuador. Basic and Applied Ecology 8: 219-230.

Lowman, M.D. 1992. Leaf growth dynamics and herbivory in five species of Australian rain-forest canopy trees. Journal of Ecology 80: 433-447.

McWilliam, A.L.C., Roberts, J.M., Cabral, O.M.R., Leitao, M.V.B.R., Decosta, A.C.L., Maitelli, G.T., Zamparoni, C.A.G.P. 1993. Leaf-area index and aboveground biomass of terra-firme rain-forest and adjacent clearings in Amazonia. Functional Ecology 7: 310-317.

Medina, E., Klinge, H. 1983. Productivity of tropical forests and tropical woodlands. In: Lange et al. (eds.). Physiological Plant Ecology - Encyclopedia of plant physiology. Springer-Verlag. New York. Vol.12d, pp. 281-303.

Mussche, S., Samson, R., Nachtergale, L., Schrijver, A.D., Lemeur, R., Lust, N. 2001. A comparison of optical and direct methods for monitoring the seasonal dynamics of leaf area index in deciduous forests. Silva Fennica 35: 373-384.

Neumann, H.H., Den Hartog, G.D., Shaw, R.H. 1989. Leaf-area measurements based on the hemispheric photographs and leaf-litter collection in a deciduous forest during autumn leaf-fall. Agricutural and Forest Meteorology 45: 325-345.

Odum, H.T. 1970. Summary: an emerging view of the ecological system at El Verde. In: Odum, H.T., Pidgeon, R.F. (eds.): A tropical rain forest: a study of irradiation and ecology at El Verde, Puerto Rico. Washington D.C.; Division of Technical Information U.S. Atomic Energy Commission, pp: I-191-I-289.

Ovington, J.D., Olson, J.S. 1970. Biomass and chemical content of El Verde lower montane rain forest plants. In: Odum, H.T., Pidgeon, R.F. (eds.). A tropical rain forest: a study of irradiation and ecology at El Verde, Puerto Rico. Washington D.C., Division of Technical Information U.S. Atomic Energy Commission. pp. H-53-H-77.

Poorter, H., Van der Werf, A. 1998. Is inherent variation in RGR determined by LAR at low irradiance and by NAR at high irradiance? A review of herbaceous species. In: Lambers, H., Poorter, H., Van Vuuren, M.M.I. (eds.). Inherent variation in plant growth, physiological mechanisms and ecological consequences. Backhuys, Leiden. The Netherlands. pp. 309-336. 
Raich, J.W., Russell, A.E., Vitousek, P.M. 1997. Primary productivity and ecosystem development along an elevational gradient on Mauna Loa, Hawai'i. Ecology 78: 707721.

Smith, F.W., Sampson, A.D., Long, N.J. 1991. Comparison of leaf area index estimates from tree allometrics and measured light interception. Forest Science 37: 1682-1688.

Takyu, M., Aiba, S.-I., Kitayama, K. 2002. Effects of topography on tropical lower montane forests under different geological conditions on Mount Kinabalu, Borneo. Plant Ecology 159: 35-49.

Takyu M, Aiba SI, Kitayama K. 2003. Changes in biomass, productivity and decomposition along topographical gradients under different geological conditions in tropical lower montane forests on Mount Kinabalu, Borneo. Oecologia 134: 397-404.

Tanner EVJ. 1980. Studies on the biomass and productivity in a series of montane rain forests in Jamaica. Journal of Ecology 68: 573-588.

van Gardingen PR, Jackson GE, Hernandez-Daumas S, Russell G, Sharp L. 1999. Leaf area index estimates obtained for clumped canopies using hemispherical photography. Agricultural and Forest Meteorology 94: 243-257.

Wang HQ, Hall CAS, Scatena FN, Fetcher N, Wu W. 2003. Modeling the spatial and temporal variability in climate and primary productivity across the Luquillo Mountains, Puerto Rico. Forest Ecology and Management 179: 69-94.

Weaver PL, Murphy PG. 1990. Forest structure and productivity in Puerto Rico, Luquillo Mountains. Biotropica 22: 69-82.

Weiss M, Baret F, Smith GJ, Jonckheere I, Coppin P. 2004. Review of methods for in situ leaf area index (LAI) determination Part II. Estimation of LAI, errors and sampling. Agricultural and Forest Meteorology 121: 37-53.

Welles JM, Normann JM. 1991. Instrument for indirect measurement of canopy architecture. Agricultural Journal 83: 818-825.

Whitford KR, Colquhoun IJ, Lang ARG, Harper BM. 1995. Measuring leaf-area index in a sparse eucalypt forest - a comparison of estimates from direct measurement, hemispherical photography, sunlight transmittance and allometric regression. Agricultural and Forest Meteorology 74: 237-249.

Wilcke W, Yasin S, Schmitt A, Valarezo C, Zech W. 2008. Soils along the altitudinal transect and in catchments. Beck E, Bendix J, Kottke I, Makeschin F, Mosandl R, editors. Gradients in a Tropical Mountains Ecosystem of Ecuador. Springer Verlag, Berlin, Heidelberg, Ecological Studies 198, in press.

Wilson PJ, Thompson K, Hodgson JG. 1999. Specific leaf area and leaf dry matter content as alternative predictors of plant strategies. New Phytologist 143: 155-162. 


\section{BIOMASS AND PRODUCTIVITY OF \\ FINE AND COARSE ROOT DYNAMICS \\ IN FIVE TROPICAL MONTANE FORESTS \\ ALONG AN ALTITUDINAL TRANSECT IN \\ SOUTH ECUADOR ${ }^{*}$}

\subsection{Abstract}

In five South Ecuadorian mountain forests along a transect from 1000 to $3000 \mathrm{~m}$ a.s.1., fine $(<2 \mathrm{~mm}$ in diameter), coarse $(20-50 \mathrm{~mm})$ and large root biomass $(>50 \mathrm{~mm})$ were analysed by soil coring and excavation in soil pits. Fine root production was estimated synchronously by three different approaches (sequential soil coring, the ingrowth core method, and the minirhizotron technique); coarse and large root production by recording diameter increment with dendrometer tapes. Fine root biomass increased 4-fold, total root biomass 2-fold from 1000 to $3000 \mathrm{~m}$. The three approaches for estimating fine root production yielded highly diverging results. According to a critical assessment the most reliable minirhizotron technique revealed a significantly increasing fine and total root production with elevation, indicating a marked carbon allocation shift from above- to belowground toward the tree line, which is most likely a consequence of increasing nutrient limitations of tree growth with growing elevation.

6.2 KEYWORDS: elevation transect, root biomass, root decomposition, root necromass, root production, tropical rainforest.

\footnotetext{
* With: Gerald Moser, Christoph Leuschner, Marina Röderstein, Sophie Graefe, Nathalie Soethe, Dietrich Hertel, .A slightly modified version of this chapter will be submitted to Plant Ecology
} 


\subsection{INTRODUCTION}

Only few studies have addressed the relevance of root systems for the productivity of tropical forest ecosystems, and if so, methodological comparisons dominated the discussion. A list of different approaches to determine fine root production have been applied; most common are "ingrowth core" and "sequential coring" approaches, which have been supplemented by "minirhizotrons" in the last few years. Only theoretical reflections have been published on the growth evaluation of coarse and large roots (Clark et al. 2001b). Therefore, the belowground compartment either plays a minor role in most publications about the net primary production (NPP) of tropical forests, or rough estimates dominate the discussion.

The change in productivity of tropical rainforests along altitudinal transects has been studied in different tropical regions, such as Malaysia (Kitayama \& Aiba 2002), Puerto Rico (Weaver \& Murphy 1990, Wang et al. 2003) and Hawai'i (Raich et al. 1997). However, in all these studies, only aboveground net primary production (ANPP) was measured. In tropical montane forests, belowground productivity has so far only been included as a constant portion of ANPP while precise empirical data is missing (Wang et al. 2003).

Clark et al. (2001a) proposed a lower boundary for belowground net primary production (BNPP) of 0.2 times ANPP and an upper boundary of 1.2 times ANPP, which demonstrates that missing data of BNPP for tropical forests may produce a large bias in productivity estimates. Accordingly, their review of total NPP data of tropical lowland and montane forests gives a range of values from 1.7 to $21.7 \mathrm{Mg} \mathrm{C} \mathrm{ha}^{-1} \mathrm{yr}^{-1}$. These results reflect the fact that our knowledge on root production in tropical forest ecosystems is very limited and no adequate model is available to predict changes in the ratio between above- and belowground production along environmental gradients such as precipitation, temperature and elevation. Until recently, precise data on root production in tropical montane forests has been completely lacking, leaving large uncertainties in our knowledge about the carbon balance and $\mathrm{C}$ turnover in these forests.

We conducted a comprehensive study on tree root mass and root dynamics in five tropical mountain forests of South Ecuador with the objectives (i) to quantify the biomass of fine and coarse roots in five mountain forests between 1000 and $3000 \mathrm{~m}$ elevation, (ii) to estimate fine and coarse root production, applying up to 3 independent methods, and (iii) to investigate elevation effects along a 2000 -m-altitudinal transect on root biomass and root production.

\subsection{Material AND Methods}

\subsubsection{STUDY SITES}

Our study was conducted at an altitudinal transect on the eastern slopes of the South Ecuadorian Andes. Five forest stands at 1050, 1540, 1890, 2340 and $3060 \mathrm{~m}$ a.s.l. were selected in the "Podocarpus National Park" and the adjacent "Reserva Biológica San Francisco" (provinces Loja and Zamora-Chinchipe). Four sites were situated on moderately steep slopes $\left(26^{\circ}\right.$ to $\left.31^{\circ}\right)$ facing northeast to northwest, while plot \#2 was located close to a ridge and showed less inclination $\left(10^{\circ}\right)$. We selected structurally homogeneous forest sites without gaps, which were representative for the respective stands and elevation with respect to tree species composition. All plots showed no or only minimal signs of human influence. The uppermost stand represented the tree line forest in this region, although it was situated at an unusually low elevation between 3200 and $3400 \mathrm{~m}$ a.s.1. This tree line depression is characteristic for the Amotape-Huancabamba Floristic Zone between $3^{\circ} \mathrm{S}$ and $7^{\circ} \mathrm{S}$, where 
the lack of high Andean peaks in the western and drier Cordillera leads to the absence of a high Polylepis tree line belt (Richter et al. 2008).

A detailed characterisation of the five study plots is given in Table 6.1. Mean air temperature (measured at $1.5 \mathrm{~m}$ height inside the forest stands) and mean soil temperature in the organic layer and in the mineral topsoil $(10 \mathrm{~cm})$ were very similar and decreased by $0.5 \mathrm{~K}$ per $100 \mathrm{~m}$ elevation. The absolute temperature minimum in the organic layer at 3060 $\mathrm{m}$ elevation was $8.1^{\circ} \mathrm{C}$ while minimum air temperature was as low as $3.1^{\circ} \mathrm{C}$. Annual rainfall was similar at the three lowermost sites (around $2000 \mathrm{~mm}$ ), while the two uppermost stands showed remarkably high amounts of precipitation $(4500-5000 \mathrm{~mm})$. The mean water content of the organic layer and the mineral topsoil increased linearly with elevation. The absolute minima of soil water content were $<5 \%$ in the organic layer of the plots $1-3$ while the organic layer of the two uppermost stands remained wet throughout the whole measuring period (May 2003 - April 2004). The mineral topsoil remained relatively moist throughout the year not only in plots 4 and 5 but also in the lowermost stands (Tab. 6.1).

Table.6.1: Locations and physiogeographical characteristics of the five study sites in South Ecuador.

\begin{tabular}{|c|c|c|c|c|c|}
\hline Stand No. & 1 & 2 & 3 & 4 & 5 \\
\hline Elevation ( $m$ a.s.l.) & 1050 & 1540 & 1890 & 2380 & 3060 \\
\hline Coordinates & $\begin{array}{l}\text { S } 04^{\circ} 06^{\prime} 54^{\prime \prime} \\
\text { W } 78^{\circ} 58^{\prime} 02^{\prime \prime}\end{array}$ & $\begin{array}{l}\text { S } 04^{\circ} 06^{\prime} 42^{\prime \prime} \\
\text { W } 78^{\circ} 58^{\prime} 20^{\prime \prime}\end{array}$ & $\begin{array}{l}\text { S } 03^{\circ} 58^{\prime} 345^{\prime \prime} \\
\text { W } 79^{\circ} 04^{\prime} 648^{\prime \prime}\end{array}$ & $\begin{array}{l}\text { S } 03^{\circ} 59^{\prime} 19^{\prime \prime} \\
\text { W } 79^{\circ} 04^{\prime} 55^{\prime \prime}\end{array}$ & $\begin{array}{l}\text { S } 04^{\circ} 06^{\prime} 71^{\prime \prime} \\
\text { W } 79^{\circ} 10^{\prime} 581^{\prime \prime}\end{array}$ \\
\hline Inclination $\left({ }^{\circ}\right)$ & 26 & 10 & 31 & 28 & 27 \\
\hline \multicolumn{6}{|l|}{ Temperature $\left({ }^{\circ} \mathrm{C}\right)$} \\
\hline $\begin{array}{l}\text { Air } \\
\quad(\min -\max )\end{array}$ & $\begin{array}{c}19.4 \\
(11.5-30.2)\end{array}$ & $\begin{array}{c}17.5 \\
(11.2-26.7)\end{array}$ & $\begin{array}{c}15.7 \\
(7.9-29.4)\end{array}$ & $\begin{array}{c}13.2 \\
(7.0-25.1)\end{array}$ & $\begin{array}{c}9.4 \\
(3.1-18.8)\end{array}$ \\
\hline $\begin{array}{l}\text { Organic layer } \\
\quad(\min -\max )\end{array}$ & $\begin{array}{c}20.0 \\
(14.4-28.7)\end{array}$ & $\begin{array}{c}18.9 \\
(16.1-20.6)\end{array}$ & $\begin{array}{c}16.0 \\
(11.7-18.8)\end{array}$ & $\begin{array}{c}14.9 \\
(13.3-16.6)\end{array}$ & $\begin{array}{c}9.7 \\
(8.1-10.8)\end{array}$ \\
\hline $\begin{array}{l}\text { Mineral soil } \\
\quad(\text { min-max })\end{array}$ & $\begin{array}{c}19.4 \\
(14.4-27.4)\end{array}$ & $\begin{array}{c}18.5 \\
(17.3-19.2)\end{array}$ & $\begin{array}{c}16.4 \\
(15.3-18.2)\end{array}$ & $\begin{array}{c}13.0 \\
(11.6-13.9)\end{array}$ & $\begin{array}{c}9.8 \\
(8.7-10.7)\end{array}$ \\
\hline Rainfall $\left(m m y r^{-1}\right)$ & c. 2230 & c. 2300 & c. 1950 & c. 5000 & c. 4500 \\
\hline \multicolumn{6}{|l|}{$\begin{array}{l}\text { Soil water content } \\
\text { (vol.\%) }\end{array}$} \\
\hline $\begin{array}{l}\text { Organic layer } \\
\text { (min-max) }\end{array}$ & $\begin{array}{c}9.9 \\
(4.4-16.0)\end{array}$ & $\begin{array}{c}12.9 \\
(3.4-23.9)\end{array}$ & $\begin{array}{c}11.6 \\
(3.6-22.3)\end{array}$ & $\begin{array}{c}34.0 \\
(23.8-39.8)\end{array}$ & $\begin{array}{c}45.3 \\
(30.5-61.7)\end{array}$ \\
\hline $\begin{array}{l}\text { Mineral soil } \\
\quad(\text { min-max })\end{array}$ & $\begin{array}{c}29.7 \\
(15.3-38.5)\end{array}$ & $\begin{array}{c}30.3 \\
(20.4-43.5)\end{array}$ & $\begin{array}{c}35.4 \\
(27.4-44.7)\end{array}$ & $\begin{array}{c}44.7 \\
(35.7-48.7)\end{array}$ & $\begin{array}{c}49.1 \\
(39.5-59.5)\end{array}$ \\
\hline $\begin{array}{l}\text { Organic layer thickness } \\
\qquad(\mathrm{mm})\end{array}$ & 48 & 243 & 305 & 214 & 435 \\
\hline $\mathrm{pH}\left(\mathrm{CaCl}_{2}\right)$ & 3.94 & 3.9 & 3.52 & 3.26 & 2.86 \\
\hline $\mathrm{C} / \mathrm{N}$ (L/Of1) & 22 & 29 & 28 & 46 & 63 \\
\hline Base saturation (Ah) & 12.5 & 7.5 & 6.8 & 6.8 & 22.7 \\
\hline Soil type & $\begin{array}{l}\text { Alumic } \\
\text { Acrisol } \\
\end{array}$ & $\begin{array}{l}\text { Alumic } \\
\text { Acrisol }\end{array}$ & $\begin{array}{c}\text { Gleyic } \\
\text { Cambisol }\end{array}$ & $\begin{array}{c}\text { Gleyic } \\
\text { Cambisol }\end{array}$ & Podzol \\
\hline
\end{tabular}

Air temperature (annual mean and extremes in parentheses) was measured at $1.5 \mathrm{~m}$ height inside the stands, and soil temperature in the organic layer and at $10 \mathrm{~cm}$ depth of the mineral soil (means and extremes), both between May 2003 and April 2004. Rainfall was recorded in gaps at 1050, 1950, 2680 and $3170 \mathrm{~m}$ and extrapolated to the study sites (data from P. Emck (sites 3-5), and own measurements). Volumetric soil water content was measured continuously with TDR probes in the organic layer and the mineral soil at $10 \mathrm{~cm}$ depth (annual means and extremes). $\mathrm{pH}\left(\mathrm{CaCl}_{2}\right)$ of the mineral topsoil $(0-30 \mathrm{~cm}), \mathrm{C} / \mathrm{N}$ ratio of organic layer (L/Of1), base saturation (Ah) and soil type were determined by Iost (2007). 
The soils of the two lowermost stands were classified as Alumic Acrisols derived from granodiorites. The Gleyic Cambisols of the stands 3 and 4 and the Podzols of stand 5 derived from shale, quartzite and sandstone. The depth of the organic layer increased nearly tenfold from 1050 to $3060 \mathrm{~m}$ and was accompanied by a threefold increase of the $\mathrm{C} / \mathrm{N}$ ratio in the organic layer and the mineral topsoil. The $\mathrm{pH}$ of the mineral soil was low and decreased with elevation. The base saturation of the mineral topsoil was highest in stand 5 close to the treeline $(23 \%)$ and two to three times lower in the stands 1 to 4 (data on soil type and chemistry from Iost 2007).

Aboveground forest structure changed noticeably with elevation. Mean canopy height decreased by a factor of 3 from 1000 to $3000 \mathrm{~m}$, mean diameter at breast height (DBH) about 2.5-fold (Tab. 6.2). Basal area showed no significant altitudinal trend but reached a maximum at $3060 \mathrm{~m}$, where stem density was very high. LAI decreased nearly 3-fold along the slope. More details on the aboveground structure of the five forest stands is given by Moser et al. (2007) and Moser et al. (2008).

Table 6.2: Aboveground structure of the five studied forest stands.

\begin{tabular}{llllll}
\hline Stand No. & $\mathbf{1}$ & $\mathbf{2}$ & $\mathbf{3}$ & $\mathbf{4}$ & $\mathbf{5}$ \\
\hline Elevation $(m)$ & 1050 & 1540 & 1890 & 2380 & 3060 \\
Canopy height $(m)$ & 31.8 & 21.7 & 18.9 & 12.0 & 9.0 \\
LAl $\left(m^{2} m^{-2}\right)$ & $6.0 \pm 0.4^{\mathrm{a}}$ & $5.4 \pm 0.4^{\mathrm{a}}$ & $5.7 \pm 0.5^{\mathrm{a}}$ & $2.8 \pm 0.2^{\mathrm{b}}$ & $2.2 \pm 0.2^{\mathrm{c}}$ \\
DBH $(\mathrm{cm})$ & $17.3 \pm 1.3^{\mathrm{a}}$ & $11.5 \pm 0.6^{\mathrm{b}}$ & $12.2 \pm 0.8^{\mathrm{b}}$ & $9.8 \pm 0.6^{\mathrm{c}}$ & $7.2 \pm 0.4^{\mathrm{d}}$ \\
Basal area $\left(\mathrm{m}^{2} \mathrm{ha}^{-1}\right)$ & 33.6 & 27.5 & 36.9 & 27.2 & 42.2 \\
\hline
\end{tabular}

Given are mean canopy height, DBH (mean \pm SE), basal area (see Moser et al. 2008), and LAI (mean \pm SE, from Moser et al. 2007). Different letters indicate significant differences between forest stands $(\mathrm{p}<0.05)$.

\subsubsection{BIOMASS AND PRODUCTION OF COARSE AND LARGE ROOTS}

For measuring the biomass of coarse and large roots 12 to 16 soil pits $(40 \mathrm{~cm} \mathrm{x} 40 \mathrm{~cm})$ per plot were dug by cutting the dense root systems with a handsaw and then excavating the soil from the surface to $50 \mathrm{~cm}$ depth of mineral soil. All root biomass (live roots) and necromass (dead roots) with a root diameter $>2 \mathrm{~mm}$ was extracted and the root material separated into organic layer and five mineral soil horizons (0-10, 10-20, 20-30, 30-40 and 40-50 cm). In the laboratory of the "Estacíon Científica San Francisco" (ECSF), all roots were washed and sorted into five different diameter classes $(0.2-1,1-2,2-5,5-10$, and $>10 \mathrm{~cm})$ and dried at $70^{\circ} \mathrm{C}$ to constant mass.

The wood increment of coarse and large roots was measured with diameter tapes made of astralon which gave increment with an accuracy of $0.01 \mathrm{Pi} \times \mathrm{cm}$ (D1, UMS GmbH Munich, Germany). In every plot, 20 root segments close to the soil surface where equipped with tapes. The diameter increment was recorded every three months from April 2003 to September 2004. The original diameter of the roots varied between 3 and $32 \mathrm{~cm}$. For installing the tapes, a small soil hole was carefully dug in proximity of a root while taking care not to damage it. The volume increment of the 20 investigated roots per plot was extrapolated to the stand level based on information about coarse and large root biomass, root diameter distribution and stem density of the five stands. 


\subsubsection{FINE ROOT BIOMASS AND PRODUCTION}

In an attempt to quantify the fine root production in the five forest stands, three different approaches were pursued: (i) sequential soil coring (Vogt \& Persson 1991) in combination with a maximum-minimum calculation procedure (Edwards \& Harris 1977, McClaugherty et al. 1982), and sequential coring in combination with a compartmental flow calculation (McClaugherty et al. 1982, Santantonio \& Grace 1987), (ii) the ingrowth core method (Persson 1980, Powell \& Day 1991, Majdi 1996), and (iii) the minirhizotron technique (Hendrick \& Pregitzer 1992, Hendrick \& Pregitzer 1996, Nadelhoffer 2000).

\section{Sequential soil coring}

The sequential coring approach was conducted in 20 subplots $(2 \mathrm{~m} \times 2 \mathrm{~m})$ per stand, which were randomly positioned on the forest floor. The soil samples were taken with a steel corer $(\mathrm{d}=3.5 \mathrm{~cm})$ in the organic layer and the uppermost $20 \mathrm{~cm}$ of the mineral soil between October 2001 and August 2002 (plots 3-5) and between April 2003 and February 2004 (plots 1 and 2), i.e. at intervals of six weeks with 8 sampling occasions in total.

In a preliminary investigation, the vertical change in root density in the soil profile to a depth of $60-80 \mathrm{~cm}$ of mineral soil was analysed. This survey revealed that highest fine root densities occurred in the deep organic layers and in the uppermost horizons of the mineral soil, whereas root densities in the subsoil were very low. We estimated that the organic layer and the mineral soil to a depth of $30 \mathrm{~cm}$ contained about $75 \%$ or more of the profile total of tree fine root biomass. Hence, we decided to include the mineral soil from 0 to 30 $\mathrm{cm}$ depth plus the organic layer in our investigation and termed them "profile total".

The extracted soil cores were fractionated into the organic layer and the mineral soil horizons, transferred to plastic bags, and transported to the laboratory at the ECSF where the samples were stored at $4{ }^{\circ} \mathrm{C}$ and processed within 30 days.

The processing and fractionating into living fine root biomass and dead fine root necromass was done according to a method described by van Praag et al. (1988) and modified by Hertel \& Leuschner (2002). The samples were soaked in water and cleaned from soil residues using a sieve $(0.25 \mathrm{~mm}$ mesh size $)$. Only roots with a diameter $<2 \mathrm{~mm}$ were considered as fine roots. Fine root segments longer than $10 \mathrm{~mm}$ were extracted by hand. Live and dead rootlets were distinguished by colour, root elasticity and degree of cohesion of cortex, periderm and stele under the stereomicroscope. A dark cortex and stele, a white, but non-turgid cortex and stele, or the existence of only the periderm, were used as indicators for root death (Persson 1978, Leuschner et al. 2001).

Six out of 20 soil samples per plot and horizon were subjected to a detailed analysis of fine root particles $<10 \mathrm{~mm}$ length, which may account for a large portion of total fine root necromass (Bauhus \& Bartsch 1996, Hertel 1999). After the manual extraction of the long fine roots, the residue of a sample was evenly spread on a piece of filter paper $(730 \mathrm{~cm} 2)$ with 36 marked squares. Six of these squares were randomly selected and the soil material was analysed with regard to even smallest fine root fragments under the microscope. The dry mass of small dead rootlets was extrapolated to the entire sample by means of the ratio of the small dead rootlets to the large dead roots $(>10 \mathrm{~mm}$ length) that was established in a sub-sample. Fine root biomass and necromass samples were dried at $70^{\circ} \mathrm{C}(48 \mathrm{~h})$ and the analysed dry mass was used to calculate the stand total of living and dead fine root mass (unit: $\mathrm{g} \mathrm{m}-2$ ) at a given sampling date or as an annual average.

Annual fine root production was calculated from the sequential coring data with the "maximum-minimum method" (Edwards \& Harris 1977, McClaugherty et al. 1982) as the difference between maximum and minimum of fine root bio- plus necromass which was then equated with the annual fine root production. This calculation was done for each of the 20 subplots per stand separately to consider asynchronous fine root growth within a given 
stand. In this study, only the differences between sampling dates with lowest and highest total fine root mass were considered for each subplot per stand. This calculation approach neglects synchronous events of fine root production and death that may occur between the dates with highest and lowest root mass and, thus, can lead to an underestimation of fine root turnover (Aber et al. 1985, Gower et al. 1992, McClaugherty et al. 1982, Publicover \& Vogt 1993).

Since it has been stated that this calculation method might not be appropriate for tropical forest ecosystems with a low or absent seasonality of fine root growth, we additionally applied the alternative "compartmental flow method" (McClaugherty et al. 1982, Santantonio \& Grace 1987). This mass balance approach allows for the calculation of fine root production during periods of synchronous growth and mortality and also considers losses of necromass due to decomposition by applying the decision matrix of Fairley \& Alexander (1985). Fine root production is quantified from the changes of live and dead root mass in 6-wk intervals and by subsequently adding the losses due to fine root litter decay (see below) during these periods.

\section{Ingrowth cores}

In April 2003, an ingrowth core experiment was established in the five stands. At each plot, 20 soil cores $(55 \mathrm{~mm}$ in diameter and $25 \mathrm{~cm}$ in depth) were taken from the randomly distributed subplots used for the sequential coring approach. All visible fine roots in the soil material were carefully removed and the soil material was inserted back into the holes and compressed to more or less original soil density. Organic layer and mineral topsoil samples were treated separately. The cleaned material was filled back into the holes to re-establish more or less natural soil conditions. The ingrowth cores were marked with PVC tubes and re-sampled after 15 months, fractionated into organic layer and mineral topsoil and filled into polyethylene bags.

In the ECSF laboratory, the samples were stored at $4^{\circ} \mathrm{C}$ and processed within 30 days. The soil samples were washed and all fine rootlets $(>10 \mathrm{~mm}$ length), which had grown into the cores, were extracted by hand, washed and dried $\left(70^{\circ} \mathrm{C}, 48 \mathrm{~h}\right)$. Preliminary studies in these plots had shown, that fine root ingrowth into the cores started about 3 months after the beginning of the experiment. Thus, we assumed that the fine root biomass detected in the cores after 15 months reflected a fine root growth period of $12 \mathrm{mo}$. Because the depth of the ingrowth cores was $25 \mathrm{~cm}$, production estimates obtained with this method cover only the organic layer, at least at the high-elevation plots with thick humus layers. With the fine root biomass data from the organic layer and the mineral topsoil, the ingrowth core production estimates were extrapolated to the soil profile covered by the sequential coring approach (organic layer plus mineral soil to $20 \mathrm{~cm}$ ).

\section{Minirhizotrons}

As another independent method for studying fine root dynamics, ten transparent minirhizotron tubes with an external diameter of $70 \mathrm{~mm}$ were installed in June 2005 in each plot. They were placed vertically to the soil surface and installed in a depth of ca. $40 \mathrm{~cm}$ wherever possible. In this study, only the first $10 \mathrm{~cm}$ below soil surface were considered for analysis of fine root dynamics, as the very high stone content of the mineral soil at the lowermost site did not allow a deeper placement of the tubes in several cases. For monitoring root growth a root scanner system (CI-600 Root Growth Monitoring System, CID Inc., USA) was used in monthly intervals until January 2007. Only data from November 2005 onwards were considered for analysis to avoid artefacts due to disturbance during tube installation. The images were analyzed with the program WinRHIZO Tron (Régent, Canada). Only fine roots (diameter $<2 \mathrm{~mm}$ ) were taken into account for the 
analysis. Relative root length production and relative root loss (in $\mathrm{cm} \mathrm{cm}-1 \mathrm{mo}-1$ ) were calculated by relating root length production or root loss between two observation dates to the visible root length at the previous measuring date. Extrapolation of this data to a full year allowed for an estimation of average annual root production and loss rate (turnover rate in $\%$ of the standing stock) and root longevity (days) of the visible fine root population in the rhizotron tubes (Nadelhoffer 2000). From turnover rates at the uppermost $10 \mathrm{~cm}$ and biomass data from the organic layer and mineral topsoil $(0-20 \mathrm{~cm})$, annual fine root production was calculated for the five forest stands.

\subsubsection{FINE ROOT LITTER DECOMPOSITION}

Decomposition of fine root litter was studied using two different litter bag experiments in the five forest stands, mostly following the protocol given by Fahey et al. (1988). In the first experiment, we investigated the decomposition rate of dead fine root material at the site of origin. We sampled fresh fine root material from the organic layer of each stand in March 2003, cleaned it from soil residues and inserted $5 \mathrm{~g}$ of this material into each litter bag (nylon, $10 \mathrm{~cm} \times 10 \mathrm{~cm}$, mesh size $1 \mathrm{~mm}, \mathrm{n}=12$ ). Additional fine root material was immediately dried for water content determination. We exposed the litter bags at random positions in each plot within the organic layer and covered them by a thin layer of leaves. After 12 months of exposure in the field, the litter bags were recollected from the stands; the remaining roots were carefully cleaned from soil residues, dried and weighed. In a second litter bag experiment starting in January 2004, we sampled fresh fine roots from the mid-elevation plot \#3 (1890 m a.s.l.) and exposed this material at the five plots for 6 months to estimate fine root decomposition rate independently from differences in root properties between the five stands that could influence decay. This approach aimed at measuring potential decomposition rates of standard material along the slope. In both experiments, decomposition rate was calculated as the difference between initial root mass and remaining root mass of a litter bag after the 6- or 12-mo exposure period.

To obtain additional chemical data which control the decomposability of fine roots, the $\mathrm{C} / \mathrm{N}$ ratios of fresh fine root biomass and necromass $(n=40)$ were measured with a $\mathrm{CN}$ Analyser (Vario EL III, Fa. Elementar, Hanau, Germany) and the polyphenol concentration of fine roots $(n=10)$ from the organic layer was determined by photometry (DU 640 Spektralphotometer, Fa. Beckmann, Germany, data supported by M. Unger). Fresh fine root material was separated from soil residues and directly frozen at $-20^{\circ} \mathrm{C}$. After the transport of the samples to Göttingen under permanent cooling, they were ground to powder under fluid nitrogen in a mortar. For analysis of soluble and insoluble tannin concentration, a repeated treatment by suspending the sample in methanol (twice) and later in acid-butanol and $\mathrm{FeNH}_{4}\left(\mathrm{SO}_{4}\right)_{2} .12 \mathrm{H}_{2} \mathrm{O}$ was conducted, followed by incubation at different temperatures (the first time in an ultra-wave bath) and centrifugation (4500 rpm). Proanthocyanidin was used as a standard solution and measured alternating with the sample solutions at $550 \mathrm{~nm}$ wavelength. To analyse the concentrations of soluble and insoluble phenols, a similar procedure was conducted. Folin-ciocalteus-phenol and $\mathrm{Na}_{2} \mathrm{CO}_{3}$ solution were used as reagents for soluble phenols; the standard solution was catechin (Fluka, Buchs, Switzerland). Insoluble phenols were detected after adding n-hexan (Merck, Darmstadt, Germany) and $\mathrm{NaOH}$; the standard solution was P-coumarin-acid (Fluka, Buchs, Switzerland). To measure the concentration of soluble and insoluble phenols, the sample solutions were analyzed in the photometer at $765 \mathrm{~nm}$ alternating with the respective standard solutions. All obtained concentration data were related to the fresh weight of each sample. 


\subsubsection{STATISTICAL ANALYSIS}

Differences in root biomass, root production and decomposition rate between the five stands were analysed with a non-parametric analysis of variance (Kruskal-Wallis test) and a Mann-Whitney two-sample test (U-test) using the package SAS (SAS Institute, Cary, NC, USA, version 8.2).

Linear and simple non-linear regression analyses were applied to identify significant effects of elevation, mean air temperature, annual precipitation, soil moisture, and proton concentration of the mineral soil, or $\mathrm{C} / \mathrm{N}$ ratio of the organic layer on root biomass and root production estimates. Additional regression analyses were performed to detect significant effects of polyphenol content or $\mathrm{C} / \mathrm{N}$ ratio of fine root mass on litter decomposition rate. All calculations were done using Xact software (SciLab, Hamburg, Germany, version 8.0).

\subsection{RESULTS}

\subsubsection{ROOT BIOMASS DISTRIBUTION}

Total belowground biomass (fine, coarse and large roots) was largest at the highest elevation (site \#5). Between 1050 and $2380 \mathrm{~m}$ a.s.1., it ranged from 23.9 to $36.3 \mathrm{Mg} \mathrm{ha}^{-1}$ (Tab. 6.3). The increase of total root biomass with elevation was mainly caused by a conspicuous root mass increase within the organic layer. In the shallow organic layer of stand \#1, only small amounts of fine, coarse and large root biomass were found, but as the thickness of the organic layer increased with elevation, root biomass did so as well. Most of the root biomass in the forest stands \#2-5 was concentrated in the organic layer, reaching $83 \%$ of the profile total at site \#4 followed by $77 \%$ at site $\# 5$. Below $30 \mathrm{~cm}$ depth of the mineral soil, only very few coarse and large roots were found. Total root biomass correlated with all seven tested environmental factors, although closest with $\mathrm{C} / \mathrm{N}$ ratio and proton concentration (Tab. 6.4).

Table 6.3: Standing biomass of coarse and large roots (diameter $>2 \mathrm{~mm}$ ) and living fine roots $(<2$ $\mathrm{mm})$ in the organic layer, mineral soil $(0-30 \mathrm{~cm})$ and the total profile in $\mathrm{Mg} \mathrm{ha}^{-1}$ at the five forest stands.

\begin{tabular}{|c|c|c|c|c|c|c|}
\hline Stand No. & & 1 & 2 & 3 & 4 & 5 \\
\hline Elevation (m) & & 1050 & 1540 & 1890 & 2340 & 3060 \\
\hline \multirow[t]{3}{*}{ Coarse and large roots } & org & $2.2 \pm 0.6^{a}$ & $22.2 \pm 4.0^{b}$ & $12.3 \pm 2.1^{\mathrm{b}}$ & $24.0 \pm 4.9^{b}$ & $37.8 \pm 4.3^{b}$ \\
\hline & $\min$ & $26.8 \pm 7.5^{\alpha}$ & $8.1 \pm 3.0^{\alpha}$ & $4.7 \pm 1.7^{\beta}$ & $3.0 \pm 0.6^{\beta}$ & $8.5 \pm 2.3^{\alpha}$ \\
\hline & $\begin{array}{l}\text { profile } \\
\text { total }\end{array}$ & $29.4 \pm 8.4^{\mathrm{AB}}$ & $30.7 \pm 8.2^{A}$ & $19.6 \pm 2.6^{B}$ & $32.7 \pm 5.7^{\mathrm{A}}$ & $51.9 \pm 4.7^{\mathrm{C}}$ \\
\hline \multirow[t]{3}{*}{ Fine roots } & org & $0.5 \pm 0.1^{a}$ & $3.6 \pm 0.3^{b}$ & $2.4 \pm 0.2^{c}$ & $3.6 \pm 0.3^{b}$ & $6.5 \pm 0.3^{d}$ \\
\hline & $\min$ & $2.2 \pm 0.2^{\alpha}$ & $2.2 \pm 0.2^{\alpha}$ & $3.3 \pm 0.2^{\beta}$ & $2.8 \pm 0.3^{\alpha \beta}$ & $4.8 \pm 0.3^{Y}$ \\
\hline & $\begin{array}{l}\text { profile } \\
\text { total }\end{array}$ & $2.7 \pm 0.3^{\mathrm{A}}$ & $5.6 \pm 0.4^{B}$ & $6.2 \pm 0.3^{B}$ & $6.3 \pm 0.6^{\mathrm{B}}$ & $10.8 \pm 0.6^{C}$ \\
\hline All roots & $\begin{array}{l}\text { profile } \\
\text { total }\end{array}$ & 32.1 & 36.3 & 26.1 & 39.4 & 62.7 \\
\hline
\end{tabular}

Different letters indicate significant differences between the stands $(\mathrm{p}<0.05)$. Given are means \pm SE (coarse and large roots $\mathrm{n}=12$; fine roots $\mathrm{n}=15$ ).

The contribution of fine roots to total root biomass increased with elevation. Similar to total root mass, fine root biomass also correlated significantly with all tested environmental 
parameters except for precipitation. While fine root biomass increased linearly with elevation, fine root necromass increased even exponentially (Fig. 6.1).

At the two lowermost sites (\#1 and 2), fine root biomass and necromass were of similar size; in contrast, the necromass exceeded the biomass by a factor of 2.7 at the highest altitude. Taken alone, coarse and large root biomass were smallest at site \#3 and highest at site \#5. In the stands \#1, 2 and 4, coarse and large root biomass reached intermediate values of about $30 \mathrm{Mg} \mathrm{ha}^{-1}$. These large diameter roots showed no significant relation to any of the tested environmental variables (Tab. 6.4). One reason is that the spatial variability in coarse and large root biomass was very high, in particular at the lowermost sites.

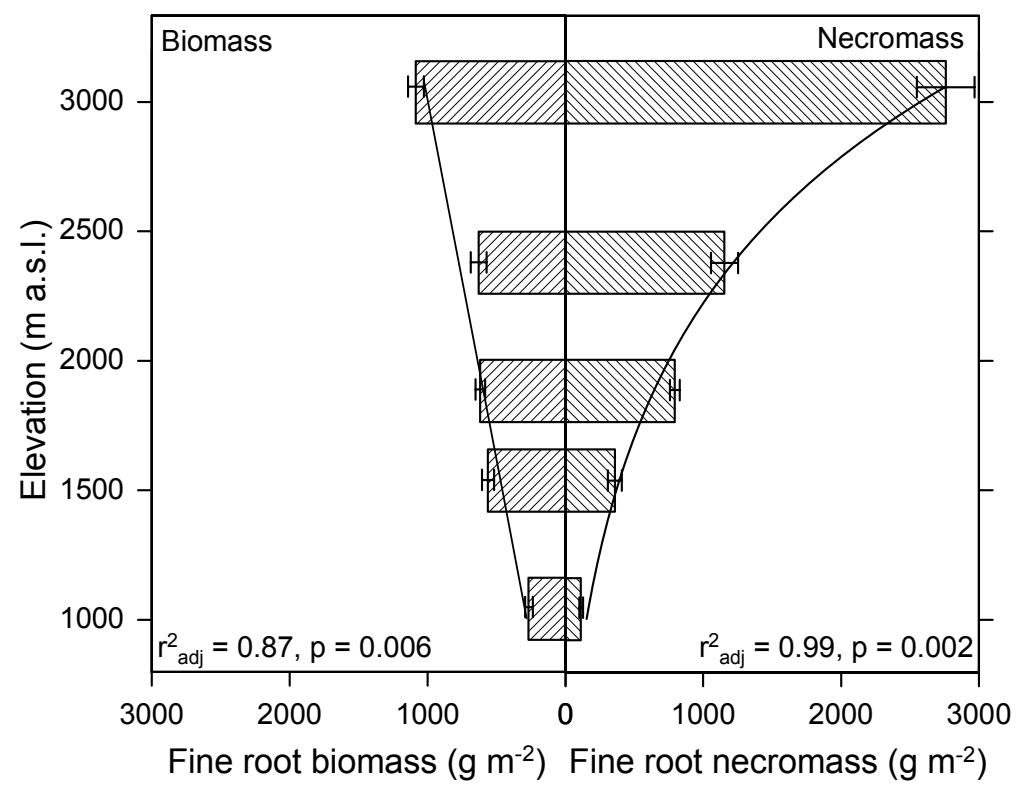

Figure. 6.1: Fine root biomass and necromass along the elevation transect. Given are means \pm SE of bio- and necromass of profile totals $(0-50 \mathrm{~cm}$ of mineral soil and organic layer, $n=15$ samples each) and results of the regression analysis.

\subsubsection{FINE ROOT DECOMPOSITION}

The decomposition rate of fresh fine root material from the five stands when exposed at the site of origin was very similar at the three lowermost sites but decreased toward the uppermost two stands (Fig. 6.2). When regressed against elevation, a significant decrease to about a third of the rate at $1050 \mathrm{~m}$ appeared at the uppermost site $(3060 \mathrm{~m})$. The "potential decomposition rate", determined by exposing "standard material" from plot \#3, was in all stands higher than the decomposition rate of the local root material, except for stand \#3.

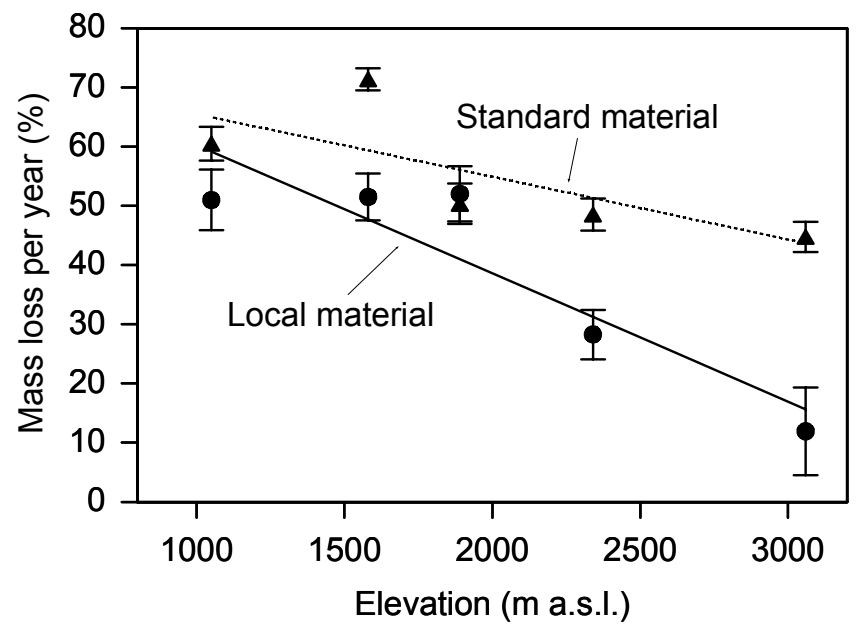

Figure 6.2: Annual fine root decomposition expressed as percental mass loss of initial fresh root mass in litterbags along the elevation transect. Exposed was either local root material (12 months expositure period, $\mathrm{r}^{2}=0.83, \mathrm{p}=0.015$ ), or root material from plot $\# 3$ at $1850 \mathrm{~m}$ ("standard material", 6 months expositure, $\left.\mathrm{r}^{2}=0.56, \mathrm{p}=0.073\right)$. Given are means $\pm \mathrm{SE}$ $(\mathrm{n}=12)$. 
The decomposition of standard root material showed a weakly significant trend for an upslope decrease $(\mathrm{p}=0.07)$.

The concentration of soluble phenols in fine root biomass increased significantly with elevation (Tab. 6.5) while insoluble phenols rather tended to decrease $\left(\mathrm{r}^{2}=0.48, \mathrm{p}=0.099\right)$. The concentration of soluble tannin content in fine root biomass decreased from $1000 \mathrm{~m}$ to a minimum at $1890 \mathrm{~m}$ and reached its maximum at $3060 \mathrm{~m}$, while insoluble tannin concentration showed no significant differences between the five forest stands. A correlation analysis showed that the decomposition rate of local root material significantly decreased with a higher soluble phenol $\left(r^{2}=0.96\right.$, $p=0.002)$ and soluble tannin concentration $\left(r^{2}=0.71\right.$, $\mathrm{p}=0.037$ ) and also with an increasing $\mathrm{C} / \mathrm{N}$ ratio of the root material from the organic layer of each plot (fine root biomass: $r^{2}=0.90, p=0.006$; fine root necromass: $\left.\mathrm{r}^{2}=0.94, \mathrm{p}=0.003\right)$.

\subsubsection{ROOT PRODUCTION}

The annual production of coarse and large roots (i.e. roots $>2 \mathrm{~mm}$ ) was about $0.2 \mathrm{Mg} \mathrm{ha}^{-1} \mathrm{yr}^{-1}$ in the stands \# 1, 3 and 4, but reached significantly higher values at the sites \#2 and 5 (Tab.6.6). Neither the five investigated environmental variables nor elevation had a significant influence on coarse and large root production.

Fine root production as estimated by a sequential coring approach combined with the maximumminimum calculation procedure increased more than tenfold along the transect (Tab.6.7) and showed the strongest positive correlation with the $\mathrm{C} / \mathrm{N}$ ratio of the organic layer and the proton concentration of the mineral soil (Tab.6.8). The max-min production values also increased significantly with mean soil water content, but decreased with temperature. The production estimates correlated negatively with leaf area index $(\mathrm{r} 2=0.85, \mathrm{p}=0.012)$ and annual leaf production $(\mathrm{r} 2=0.087, \mathrm{p}=0.010$; data from Moser et al. 2007).

Sequential coring combined with a compartmental flow calculation yielded unrealistically high values at the stands \# 3, 4 and 5; the data was omitted from further analysis.

In contrast to the sequential coring calculation approaches, the ingrowth core approach resulted in relatively low production estimates, indicating an absolute minimum of fine root production at $1050 \mathrm{~m}$, a maximum at $1540 \mathrm{~m}$ and a continuous decrease toward $3060 \mathrm{~m}$ elevation (Tab.6.7). The production data of this approach did not correlate significantly with any of the

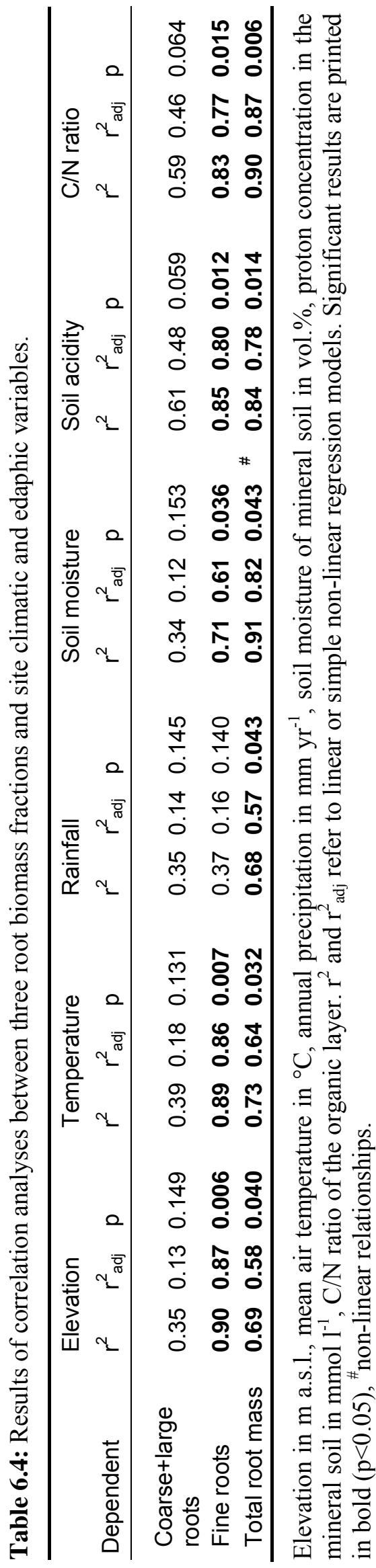


tested environmental variables (Tab.6.8).

A relationship between ingrowth core-derived root production and leaf production appeared when only the stands \#2-5 were included in the analysis (LAI: $r 2=0.71, p=0.080$; annual leaf production: $\mathrm{r} 2=0.81, \mathrm{p}=0.050$ ).

The minirhizotron data combined with the root biomass totals of the $0-20 \mathrm{~cm}$ profile showed a more than 4-fold increase of fine root production with elevation.

Total root production (BNPP) was estimated as the sum of fine, coarse and large root production, the first component being calculated alternatively with the approaches mentioned above (Fig.6.3). BNPP obtained from the max-min calculation or from minirhizotron data increased 10 - and 4-fold along the slope, respectively. Total root production as estimated from ingrowth cores was somewhat higher at the lowermost two sites than the results obtained from the other approaches. While the BNPP estimates based on the max-min, the compartmental flow calculation, or on the minirhizotron data correlated with soil $\mathrm{CN}$ ratio, soil acidity, soil moisture and temperature (or elevation), the ingrowth core-based data did not depend significantly on any of these variables. Rainfall was not related to any BNPP estimate (Tab.6.8).

Table 6.5: Polyphenol concentration of fine root biomass and $\mathrm{C} / \mathrm{N}$ ratio of fine root bio- and necromass of the organic layer at the five forest stands.

\begin{tabular}{llllll}
\hline Stand No. & $\mathbf{1}$ & $\mathbf{2}$ & $\mathbf{3}$ & $\mathbf{4}$ & $\mathbf{5}$ \\
\hline $\begin{array}{l}\text { Elevation }(m) \\
\text { Polyphenols } \\
\left(m g g^{-1} \text { fresh biomass) }\right.\end{array}$ & 1050 & 1540 & 1890 & 2340 & 3060 \\
Phenol $_{\text {Soluble }}$ & $1.7 \pm 0.4^{\mathrm{a}}$ & $2.3 \pm 0.3^{\mathrm{a}}$ & $2.3 \pm 0.5^{\mathrm{a}}$ & $3.9 \pm 1.2^{\mathrm{b}}$ & $4.9 \pm 0.7^{\mathrm{b}}$ \\
Phenol $_{\text {Insoluble }}$ & $4.2 \pm 0.8^{\mathrm{a}}$ & $12.9 \pm 2.3^{\mathrm{b}}$ & $7.4 \pm 1.6^{\mathrm{ab}}$ & $7.6 \pm 1.8^{\mathrm{ab}}$ & $19.8 \pm 2.6^{\mathrm{c}}$ \\
Tannin $_{\text {Soluble }}$ & $4.8 \pm 1.9^{\mathrm{a}}$ & $6.9 \pm 1.1^{\mathrm{a}}$ & $4.9 \pm 1.3^{\mathrm{a}}$ & $6.0 \pm 1.0^{\mathrm{a}}$ & $14.5 \pm 1.7^{\mathrm{b}}$ \\
Tannin $_{\text {Insoluble }}$ & $50.4 \pm 8.2^{\mathrm{ab}}$ & $57.3 \pm 5.6^{\mathrm{b}}$ & $51.0 \pm 7.2^{\mathrm{ab}}$ & $34.4 \pm 4.2^{\mathrm{a}}$ & $45.8 \pm 7.2^{\mathrm{ab}}$ \\
C/N ratio & & & & & \\
Fine root biomass & $28.2 \pm 1.0^{\mathrm{a}}$ & $34.2 \pm 0.6^{\mathrm{b}}$ & $43.4 \pm 0.9^{\mathrm{c}}$ & $55.2 \pm 1.2^{\mathrm{d}}$ & $91.1 \pm 3.3^{\mathrm{e}}$ \\
Fine root necromass & $23.6 \pm 1.9^{\mathrm{a}}$ & $26.9 \pm 0.5^{\mathrm{a}}$ & $33.1 \pm 0.8^{\mathrm{b}}$ & $44.2 \pm 1.0^{\mathrm{c}}$ & $60.1 \pm 1.5^{\mathrm{d}}$ \\
\hline
\end{tabular}

Given are means and SE (polyphenols: $n=10 ; C / N: n=40$ ), different letters indicate significant differences between the forest stands $(\mathrm{p}<0.05)$.

Table 6.6: Stand level estimates of coarse and large root growth $(\mathrm{d}>2 \mathrm{~mm})$ in the organic layer and the mineral soil of the 5 stands as extrapolated from increment rates of 20 roots per stand and coarse and large root biomass data (in $\mathrm{Mg} \mathrm{ha}^{-1}$ ).

\begin{tabular}{|c|c|c|c|c|c|c|}
\hline \multicolumn{2}{|l|}{ Stand No. } & 1 & 2 & 3 & 4 & 5 \\
\hline \multicolumn{2}{|l|}{ Elevation $(m)$} & 1050 & 1540 & 1890 & 2340 & 3060 \\
\hline \multirow{3}{*}{$\begin{array}{l}\text { Coarse + large } \\
\text { roots }\end{array}$} & org & $0.01 \pm 0.003^{a}$ & $0.58 \pm 0.08^{b}$ & $0.16 \pm 0.02^{c}$ & $0.20 \pm 0.04^{c}$ & $0.72 \pm 0.05^{b}$ \\
\hline & $\min$ & $0.16 \pm 0.04^{\alpha}$ & $0.21 \pm 0.06^{\alpha}$ & $0.06 \pm 0.02^{\beta}$ & $0.03 \pm 0.01^{\beta}$ & $0.16 \pm 0.03^{\alpha}$ \\
\hline & $\begin{array}{l}\text { rofile } \\
\text { total }\end{array}$ & $0.17 \pm 0.04^{\mathrm{A}}$ & $0.79 \pm 0.14^{B}$ & $0.23 \pm 0.03^{\mathrm{A}}$ & $0.23 \pm 0.04^{\mathrm{A}}$ & $0.89 \pm 0.08^{B}$ \\
\hline
\end{tabular}

Given are means and SE in $\mathrm{Mg} \mathrm{ha}^{-1} \mathrm{yr}^{-1}$, different letters indicate significant differences between forest stands $(\mathrm{p}<0.05)$. 


\subsection{DisCUSSION}

\subsubsection{ALTITUDINAL CHANGE IN ROOT BIOMASS AND ITS CAUSES}

Evidence of increasing fine root biomass with elevation in tropical mountain forests has been reported from Mt. Kinabalu, Malaysia (Kitayama \& Aiba 2002) confirming our results. Moreover, a comprehensive review of fine root biomass data from tropical moist forests compiled by Hertel \& Leuschner (in press), which included the Ecuadorian data, revealed a significant exponential root biomass increase with elevation. However, the fine root biomass recorded at Mt. Kinabalu was at most elevations higher than in the Ecuadorian transect, as were the values reported from a tropical montane oak forest in Costa Rica (Hertel et al. 2003).

A causal explanation of an increase in fine root biomass, and also of fine root production, with elevation is hampered by the fact that putative influential environmental factors such as soil acidity, nitrogen shortage, soil water-logging and the concentration of toxic substances in the soil are closely correlated to each other; all of them show a general increase with elevation, or with decreasing temperature, along the slope. In the absence of experiments, assumptions on the underlying causes can be built only on their correlations.

Table 6.7: Biomass production of fine roots (Mg ha-1 $\mathrm{yr}-1)$ in the organic layer and the mineral soil $(0-20 \mathrm{~cm})$.

\begin{tabular}{|c|c|c|c|c|c|c|}
\hline Stand No. & Horizon & 1 & 2 & 3 & 4 & 5 \\
\hline Elevation $(m)$ & & 1050 & 1540 & 1890 & 2340 & 3060 \\
\hline \multirow{3}{*}{$\begin{array}{l}\text { Sequential coring } \\
\text { (Comp.flow) }\end{array}$} & org & $0.99 \pm 0.10^{\mathrm{a}}$ & $2.72 \pm 0.21^{b}$ & $14.49 \pm 0.56^{c}$ & $21.14 \pm 0.95^{d}$ & $32.98 \pm 0.93^{\mathrm{e}}$ \\
\hline & \multirow{2}{*}{$\begin{array}{l}\min \\
\text { profile } \\
\text { total }\end{array}$} & $1.17 \pm 0.07^{\alpha}$ & $1.00 \pm 0.14^{\alpha}$ & $7.70 \pm 0.21^{\beta}$ & $14.64 \pm 0.30^{x}$ & $42.62 \pm 1.68^{\delta}$ \\
\hline & & $2.15 \pm 0.13^{A}$ & $3.72 \pm 0.30^{B}$ & $\begin{array}{l}22.19 \pm \\
0.46^{\mathrm{C}}\end{array}$ & $\begin{array}{l}35.78 \pm \\
0.97^{\mathrm{D}}\end{array}$ & $75.60 \pm 2.14^{\mathrm{E}}$ \\
\hline \multirow{3}{*}{$\begin{array}{l}\text { Sequential coring } \\
\text { (Max-Min) }\end{array}$} & org & $1.44 \pm 0.14^{\mathrm{a}}$ & $4.79 \pm 0.50^{b}$ & $4.52 \pm 0.51^{b}$ & $7.89 \pm 0.99^{c}$ & $10.87 \pm 1.42^{\mathrm{d}}$ \\
\hline & \multirow{2}{*}{$\begin{array}{l}\min \\
\text { profile } \\
\text { total }\end{array}$} & $0.50 \pm 0.06^{\alpha}$ & $1.30 \pm 0.15^{\beta}$ & $2.24 \pm 0.24^{x}$ & $4.61 \pm 0.55^{\delta}$ & $11.06 \pm 1.27^{\varepsilon}$ \\
\hline & & $1.94 \pm 0.10^{A}$ & $6.09 \pm 0.33^{B}$ & $6.76 \pm 0.38^{B}$ & $\begin{array}{l}12.05 \pm \\
0.77^{\mathrm{C}}\end{array}$ & $\begin{array}{l}21.93 \pm \\
2.15^{\mathrm{D}}\end{array}$ \\
\hline \multirow[t]{3}{*}{ Ingrowth cores } & org & $0.76 \pm 0.13^{\mathrm{a}}$ & $6.08 \pm 0.67^{b}$ & $3.38 \pm 0.58^{c}$ & $3.55 \pm 0.71^{\mathrm{bc}}$ & $2.26 \pm 0.29^{c}$ \\
\hline & $\min$ & $\begin{array}{l}2.86 \pm \\
0.51^{\alpha \beta}\end{array}$ & $2.98 \pm 0.32^{\beta}$ & $3.64 \pm 0.62^{\beta}$ & $2.55 \pm 0.51^{\alpha \beta}$ & $1.52 \pm 0.20^{\alpha}$ \\
\hline & $\begin{array}{l}\text { profile } \\
\text { total }\end{array}$ & $3.62 \pm 0.65^{\mathrm{A}}$ & $9.06 \pm 1.00^{\mathrm{B}}$ & $7.02 \pm 1.21^{\mathrm{BC}}$ & $6.10 \pm 1.23^{C}$ & $3.78 \pm 0.49^{A}$ \\
\hline \multirow[t]{3}{*}{ Minirhizotrons } & org & $0.41 \pm 0.04^{\mathrm{a}}$ & $1.95 \pm 0.31^{b c}$ & $1.16 \pm 0.13^{b}$ & $2.12 \pm 0.28^{\mathrm{C}}$ & $5.71 \pm 0.76^{d}$ \\
\hline & \multirow{2}{*}{$\begin{array}{l}\min \\
\text { profile } \\
\text { total }\end{array}$} & $1.87 \pm 0.17^{\alpha}$ & $1.22 \pm 0.20^{\alpha}$ & $1.58 \pm 0.22^{\alpha}$ & $1.63 \pm 0.22^{\alpha}$ & $4.26 \pm 0.57^{\beta}$ \\
\hline & & $2.28 \pm 0.20^{A}$ & $3.16 \pm 0.51^{A B}$ & $2.97 \pm 0.31^{\mathrm{AB}}$ & $3.72 \pm 0.50^{B}$ & $9.40 \pm 1.32^{C}$ \\
\hline
\end{tabular}

Data for fine root production were estimated with four different methods: sequential coring with a maximum-minimum-calculation, sequential coring with a compartmental flow calculation, the ingrowth core approach and minirhizotrons. Given are means $\pm \mathrm{SE}$, different letters indicate significant differences between the forest stands $(\mathrm{p}<0.05)$.

Increasing nitrogen shortage with elevation is indicated by an increasing $\mathrm{C} / \mathrm{N}$ ratio of the topsoil, in particular above $2000 \mathrm{~m}$. In a fertilization experiment, nitrogen shortage was shown to limit microbial activity in these forests (Maraun et al. 2008) indicating increasing $\mathrm{N}$ limitation at higher altitudes for plants as well. Krashevska et al. 2008 found for the studied elevation gradient that the microbial biomass is generally low and peaks at $2000 \mathrm{~m}$. 
The microbial community changes from a bacterial-dominated system at low altitudes to a fungi-dominated one at high altitudes indicating a decreasing litter quality. Decomposition rates in these mountain forests are generally low and decrease with elevation (Iost 2007), which is partly a consequence of the low and decreasing abundance of primary decomposers such as oribatid mites along the elevation gradient (Illig et al. 2008; Scheu et al. 2008). This would not only result in low mineralization rates, but could also explain the thick organic layers at high elevations which consist to a large proportion of undecomposed root necromass.

Hafkenscheid (2000) concluded for montane forests in Jamaica that not only edaphic nutrient shortage is limiting plant growth, but also the low nutrient uptake capacity of fine roots in the cool and often water-logged conditions in combination with unfavourable soil chemistry.

This author found that both low concentrations of inorganic $\mathrm{N}$ or high contents of organic $\mathrm{N}, \mathrm{Al} 3+$ and $\mathrm{H}+$ may lead to high polyphenol concentrations in the soil solution of tropical mountain forests. According to a hypothesis formulated by Northup et al. (1995) complexation of nitrate ions by polyphenols can reduce the losses of NO3- with drainage water from $\mathrm{N}$ deficient soils, thereby increasing the concentration of dissolved organic $\mathrm{N}$, but reducing that of NH4+ and NO3-. Thus, elevated plant-borne phenol concentrations in the soil solution may conserve nitrogen and can also ameliorate Al3+-toxicity through complexation (Hue et al. 1986). Hafkenscheid (2000) assumed that the large amounts of phenols in the topsoil water in a stunted Jamaican mountain forest probably are mostly exudates from fine roots and not leachates from leaf litter. We found a more or less constant concentration of soluble phenols in the leaf mass (M. Unger, unpubl.), but an increasing concentration with elevation in fine root mass, which may support this hypothesis.

We conclude that adverse soil conditions in the upper montane forests, in particular low nitrogen supply, water logging and possibly also high concentrations of $\mathrm{Al}+$ and other toxic cations, restricted nutrient supply which

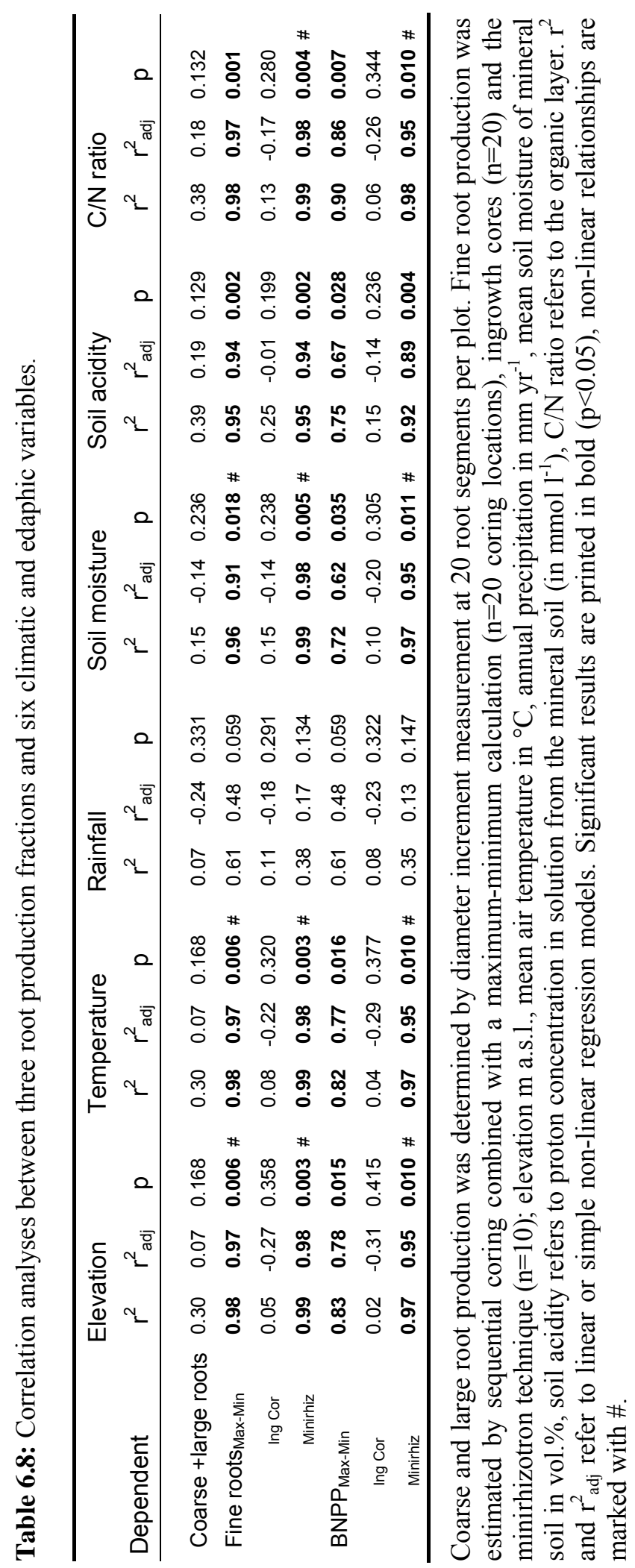


stimulates trees to enlarge their fine root system and to release high amounts of polyphenols through root exudation. Increased production of secondary metabolites in the root system together with a high fine root production, which compensates for root losses in an adverse environment, represent a considerable plant-internal sink for carbon and nutrients, which, in turn, reduces aboveground productivity and tree height. In the case of coarse and large roots, strong winds on exposed ridges and at high elevations may be an additional factor that shifts carbon allocation to the root system.

\subsubsection{ROOT PRODUCTION}

To our knowledge this is the first study that measured coarse and large root production in tropical montane forests. Clearly, calculation of coarse root production from coarse root biomass data and diameter increment recorded at 20 root segments per stand close to the soil surface is a rough estimate. While a wide range of root diameters $(2$ to $>100 \mathrm{~mm})$ was included in the coarse and large root fraction, only roots with diameters between 30 and 320 $\mathrm{mm}$ were used for increment measurement. Thus, the data can reflect the magnitude of coarse and large root production and they may indicate altitudinal trends. Highest values were observed in the most wind exposed forest stands \#2 and 5, where a high demand for tree anchorage and therefore coarse root production existed. Coarse and large root production was particularly high in the organic layer of stand \#5 with an extraordinary high standing biomass of large-diameter roots $\left(38 \mathrm{Mg} \mathrm{ha}^{-1}\right)$.

The three different methods for estimating fine root production along the elevational transect gave highly contrasting results. While the production estimates obtained with the three methods were very similar for the lowermost forest site $\# 1$ at $1050 \mathrm{~m}$ elevation, large differences between the different approaches were visible further upslope. According to the sequential coring approach, a 10-35 fold increase of fine root production (dependent on the calculation mode) should have occurred along the slope. The minirhizotron data gave a production increase with increasing elevation as well, even though fine root production of the uppermost stand was 2 to 8 -fold lower than that calculated with the sequential coring approach. Third, the ingrowth core method showed highest fine root production estimates at mid elevations but low rates at both 1050 and 3060 m elevation.

Faced with the highly diverging results of the three approaches, the specific shortcomings of the methods when applied to tropical montane forests have to be discussed (Fahey et al. 1999, Hertel \& Leuschner 2002, Lauenroth 2000, Nadelhoffer 2000).

\section{FINE ROOT PRODUCTION MEASUREMENT IN TROPICAL FORESTS - AN ASSESSMENT OF METHODS}

Various authors have analysed the pros and cons of different methods of fine root production estimation (e.g. Hendricks et al. 2006, Hertel \& Leuschner 2002, Nadelhoffer \& Raich 1992, Publicover \& Vogt 1993). These assessments led to partly contradictory results and so far no general agreement about "the best method" has been reached. In the following, we discuss the applicability and reliability of three different approaches of fine root production estimation for tropical forests, in particular for stands in montane and upper montane elevation.

\section{Sequential coring approach}

Soil core estimates of fine root production are dependent on accurate periodic assessment of root standing biomass and a low spatial variability of fine root biomass between the sampling locations. Difficulties in separating live and dead roots may cause systematic errors. Several arguments have been collected to explain possible underestimates by sequential coring approaches (Fahey et al. 1999, Lauenroth 2000, 
Hertel \& Leuschner 2002). They may be caused (i) by difficulties in synchronizing the sampling dates with the absolute minimum and maximum of fine root biomass and necromass within a year, (ii) by the simultaneous occurrence of production and mortality (Aber et al. 1985, Gower et al. 1992, McClaugherty et al. 1982, Publicover \& Vogt 1993), (iii) by a missing seasonality in fine root biomass and necromass, especially when the max-min method is applied, (iv) by low estimates of root decomposition rates when using litterbags with fresh fine roots being exposed, and (v) when the max-min method is used to estimate root production at highly fertile sites (Hendricks et al. 1993).

On the other hand, sequential coring approaches may lead to overestimation of fine root production (i) when fine root biomass is large as on low fertility sites (Hendricks et al. 1993, Kurz \& Kimmins 1987, Nadelhoffer \& Raich 1992, Singh et al. 1984), (ii) random errors of biomass estimates are high, and (iii) a high spatial heterogeneity of root biomass is linked to a weak seasonality. In the latter case, repeated sampling may lead to biomass and necromass differences that are non-significant and are additionally confounded by large random errors (Lauenroth 2000, Nadelhoffer 2000, Sala et al. 1988). Sequential coring combined with the compartmental flow calculation is particularly sensitive to overestimation under that condition (Sala et al. 1988),

In the Ecuador transect, underestimation of fine root production with the sequential coring approach most likely has occurred in the lowermost stands $(1050$ and $1540 \mathrm{~m}$ elevation), where biomass seasonality was low and root decomposition rates were most likely underestimated. Indeed, production estimates obtained from sequential coring were lower than those derived from ingrowth cores. In contrast, seasonality was higher in the uppermost stands reducing possible bias caused by this type of error. However, at 1890, 2340 and $3060 \mathrm{~m}$, fine root bio- and necromass were high and showed a large spatial variability (Tab. 6.9), in particular when applying the compartmental flow calculation. The unrealistically high production estimates for the stands \# 3 to 5 (>12 $\mathrm{Mg}$ ha-1) are probably a result of this variation.

Table 6.9: Temporal and spatial variability of fine root mass data (live and dead) in the five stands during the sequential coring campaigns.

\begin{tabular}{|c|c|c|c|c|c|c|}
\hline \multirow{2}{*}{\multicolumn{2}{|c|}{$\begin{array}{l}\text { Stand No. } \\
\text { Sequential coring }\end{array}$}} & 1 & 2 & 3 & 4 & 5 \\
\hline & & & & & & \\
\hline \multirow[t]{2}{*}{ Seasonal CV } & org & 0.81 & 0.30 & 1.10 & 1.06 & 1.14 \\
\hline & $\min$ & 0.33 & 0.55 & 1.09 & 1.17 & 1.38 \\
\hline \multirow[t]{2}{*}{ Spatial CV } & org & 0.61 & 0.15 & 0.35 & 0.32 & 0.55 \\
\hline & $\min$ & 0.32 & 0.57 & 0.56 & 0.48 & 0.70 \\
\hline
\end{tabular}

Given are means of the coefficient of variance $(\mathrm{CV})$ for seasonal $(n=8)$ and spatial $(n=64)$ patterns of total fine root biomass (live and dead) from sequential coring campaigns.

\section{Ingrowth core approach}


The ingrowth core approach is based on the assumption that root and soil disturbances during core installation do not alter root dynamics during the ingrowth period (Lauenroth 2000). This method may lead to overestimates (i) when the severing of roots during core installation stimulates the proliferation of adventitious roots, (ii) when soil chemical and physical properties have been altered, in particular in experiments with soil substrates other than the local soil, thereby promoting root growth, or (iii) when reduced root competition due to low root densities in the cores favours root growth (Fahey et al. 1999, Hertel \& Leuschner 2002, Lauenroth 2000, Vogt et al. 1998).

In the Ecuadorian transect, overestimation of fine root production from the ingrowth core data may have occurred especially at the sites \#2 and 3, where a proliferation of adventitious root growth is likely after the roots were relieved from competition in the densely rooted topsoil. In contrast, alteration of chemical and physical soil properties should have played only a minor role because local soil material was used as growing medium.

On the other hand, the ingrowth core approach should lead to underestimates of root growth in many cases, in particular when (i) the core installation represents a heavy disturbance of the rhizosphere, (ii) root growth is resumed only after a considerable delay period and the length of this period cannot be determined accurately (Vogt et al. 1998), and (iii) root disappearance due to decomposition during the experiment is not considered in the analysis (Hertel \& Leuschner 2002, Lauenroth 2000, Steele et al. 1997).

If the cores are exposed for quite long periods as in our study (i.e. $15 \mathrm{mo}$ ), the possible confounding effect of the initial disturbance may be reduced while errors related to root death and decomposition during the experiment increase. Hertel \& Leuschner (2002) proposed to use ingrowth cores with small diameters to minimize delays during the recolonization process by regrowing fine roots and to reduce effects of reduced root competition. A large problem of ingrowth core studies is the unknown length of the initial delay period. We assumed a uniform delay period of three months at all five forest sites, based on the results of a preliminary study conducted at $1900 \mathrm{~m}$ elevation. However, the delay period at lower elevations $(1050$ and $1540 \mathrm{~m})$ most likely was shorter, resulting in an overestimation of the real root production rate. On the other hand, the relatively high decomposition rates at the lower and lowermost sites of the transect may have masked this effect, rather leading to a significant underestimation of fine root production at sites \#1 and 2. At higher elevations with frequent water-logging and cool soil temperatures, the delay period may have been longer than 3 months, which makes a significant underestimation of root production at 2340 and $3060 \mathrm{~m}$ likely.

\section{Minirhizotrons}

The minirhizotron technique enables a direct observation of fine root growth and death in the rhizosphere. If combined with root biomass determination, this approach may yield more reliable estimates of fine root production of forests than all other available techniques (Hendricks et al. 2006), in particular in climates with low seasonality as in Ecuador. Installation of the rhizotron tubes may represent a similar disturbance to the rhizosphere as it occurs with the ingrowth core approach. This requires a recovery period of at least 6 mo before root birth and death may have reapproached a quasi-steady state again. In cool environments with slower root growth (as at 2450 and $3060 \mathrm{~m}$ elevation), recovery may take even longer (Graefe et al. 2008). Minirhizotron studies along temperature gradients may thus face different recovery periods at the sites to be compared. For minimizing errors in root turnover estimates caused by different recovery periods, we focused on root length loss instead of root growth, and related it to mean fine root biomass for calculating root turnover. Even if 
root birth partly represented a compensation for losses due to the initial disturbance event, root death would reflect mortality as being caused by physiological and local environmental factors, thus giving a better estimate of turnover than calculations based on root growth. Due to a variable soil profile depth along the transect, we used a uniform observation depth of $0-10 \mathrm{~cm}$ for the minirhizotrons. This approach may have introduced bias in the root turnover estimates in particular at the uppermost stands with a very thick organic layer where the root activity in the top layer may not be representative for the entire profile. Particularly at site $\# 5$, it is likely that the fine root turnover rate in the uppermost $10 \mathrm{~cm}$ of the organic layer was higher than deeper in the profile, which comprised a $48 \mathrm{~cm}$ thick organic layer and about $20 \mathrm{~cm}$ of mineral soil. Even though precise data are lacking, we assume that root growth was higher in the topsoil with a more rapid nutrient turnover, a better soil aeration and higher daytime soil temperatures than in the more unfavorable lower horizons. Therefore, fine root turnover estimates based solely on the $0-10 \mathrm{~cm}$ layer may represent an overestimation of the entire profile's turnover in the $3060 \mathrm{~m}$ stand. We assume that the high stand level estimate of fine root production obtained with the minirhizotron technique at site \#5 (9.4 $\left.\mathrm{Mg} \mathrm{ha}^{-1} \mathrm{yr}^{-1}\right)$ compared to the rates at 1980 and $2450 \mathrm{~m}\left(3.0\right.$ and $\left.3.7 \mathrm{Mg} \mathrm{ha}^{-1} \mathrm{yr}^{-1}\right)$ are partly a consequence of this invalid extrapolation to lower, less dynamic horizons.

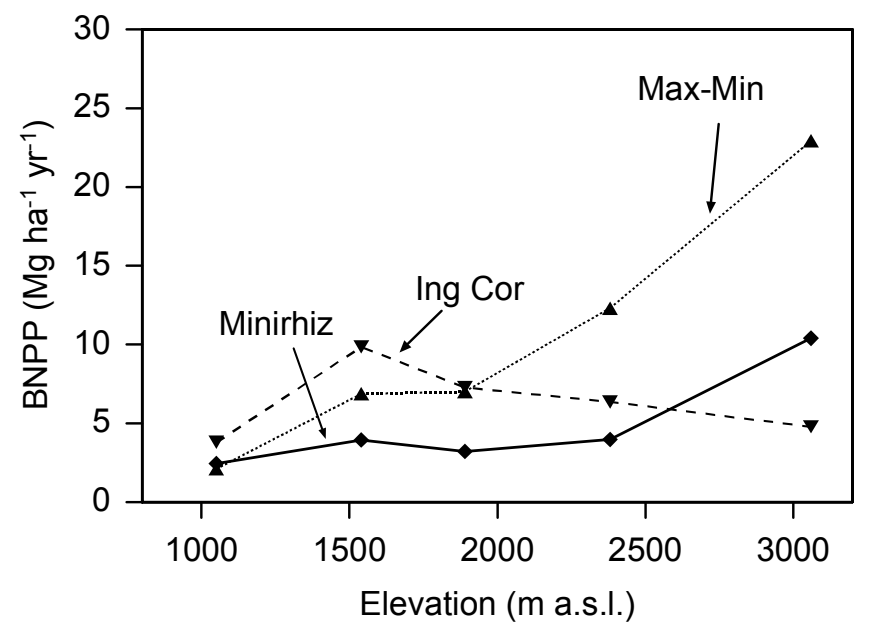

Figure 6.3: Total root production (BNPP) as the sum of fine, coarse and large root production with fine root production estimated by three different methods: Max-Min - sequential coring with maximum-minimum calculation, Ing Cor - ingrowth core approach, Minirhiz minirhizotrone technique.

\subsection{CONCLUSIONS}

All three approaches of estimating fine root production are affected by more or less serious shortcomings when applied to Ecuadorian mountain forests. The reliability of the data could best be tested by comparison of the root production and turnover values with independently derived data from tree carbon budgets. Data on leaf area index, photosynthetic activity of the trees and irradiance in the five stands of the Ecuador transect (Moser et al. 2007; Unger, unpubl. data) allow for the assumption that the canopy carbon gain of the forest stands must decrease from 1050 to $3060 \mathrm{~m}$ to about the half: while the photosynthetic capacity of the sun leaves per unit leaf area and PhAR irradiance changed only little with elevation, LAI decreased by a factor of about 2.7. On the other hand, the proportion of weakly illuminated shade leaves was much higher at lower elevation 
suggesting that the decrease in canopy carbon gain was less than deduced from the LAI decrease.

Since aboveground net primary production (stem increment, leaf growth and twig and fruit production) decreased 4.2 fold from 1050 to $3060 \mathrm{~m}$ (Moser et al. in prep), which is a stronger decrease than the assumed decline in canopy carbon gain, we assume that more carbohydrates must be available for root growth in the high-elevation stands than at lower altitudes. This is supported by the observation that aboveground wood respiration greatly decreased with elevation in this transect (Zach et al. 2008), leaving more carbohydrates for belowground sinks.

These rough estimates of carbon fluxes along the 2000-m elevation transect are sufficiently precise for rejecting the results of the sequential coring approach which gave as highly unrealistic values in the uppermost stands. The ingrowth core method revealed no clear elevational trend in fine root production and thus seems to be an unsuitable approach in these mountain forests as well. We conclude that most reliable results can be expected from the minirhizotron approach combined with a precise assessment of fine root biomass stocks, even though a certain overestimation of root turnover may have happened in the $3060 \mathrm{~m}$ stand. Future investigations need to install observation tubes in lower horizons as well for quantifying vertical differences in root activity in the thick organic profiles. The minirhizotron data show an increase in the fine root production of the stands with elevation, at least above $2000 \mathrm{~m}$, which is accompanied by a growing stock of live and dead fine roots. Coarse and large roots are particularly abundant and have elevated growth rates at sites with a high demand for tree anchorage, which is typically the case at higher elevations. Thus, our data provide evidence for the fact that carbon allocation in South Ecuadorian tropical montane trees shows a pronounced shift belowground with increasing elevation, with aboveground $\mathrm{C}$ sinks decreasing and belowground sinks increasing between 1000 and $3000 \mathrm{~m}$. According to the resource balance hypothesis formulated by Bloom et al. (1985), this conspicuous shift is best explained by a growing importance of soil resource limitation over light limitation of plant growth with increasing elevation, which would promote root over shoot growth.

\subsection{ACKNOWLEDGEMENTS}

We would like to thank S. Iost, Technical University of Dresden, for a very fruitful cooperation and for providing data on soil type, chemistry and soil biological activity, M. Unger (University of Göttingen) for his data on polyphenol content of roots and radiation, and C. Bertsch (University of Göttingen) for his help in fine root analysis. We also thank P. Emck (University of Erlangen) for precipitation data. We are grateful to the Fundacíon Científica San Francisco (Nature and Culture International) for the permission to work on the ECSF, to the Ministerio del Ambiente for research permits and to the Deutsche Forschungsgemeinschaft for financial funding within the Research Unit 402.

\subsection{REFERENCES}

Aber, J.D., Melillo, J.M., Nadelhoffer, K.J., McClaugherty, C.A., Pastor, J., 1985. Fine root turnover in forest ecosystems in relation to quantity and form of nitrogen availability: a comparison of two methods. Oecologia 66, 317-321.

Bauhus, J., Bartsch, N., 1996. Fine-root growth in beech (Fagus sylvatica) forest gaps. Canadian Journal of Forest Research 26, 2153-2159.

Bloom, A.J., Chapin III, F.S., Mooney, H.A., 1985. Resource limitation in plants - an economic analogy. Annual Review of Ecology and Systematics 16, 363-392. 
Clark, D.A., Brown, S., Kicklighter, D.W., Chambers, J.Q., Thomlinson, J.R., Ni, J., Holland, E.A., 2001a. Net primary production in tropical forests: an evaluation and synthesis of existing field data. Ecological Applications 11, 371-384.

Clark, D.A., Brown, S., Kicklighter, D.W., Chambers, J.Q., Thomlinson, J.R., Ni, J., 2001b. Measuring net primary production in forests: concepts and field methods. Ecological Applications 11, 356-370.

Edwards, N.T., Harris, W.F., 1977. Carbon cycling in a mixed deciduous forest floor. Ecology 58, 431-437.

Fahey, T.J., Hughes, J.W., Pu, M., Arthur, M.A., 1988. Root decomposition and nutrient flux following whole-tree harvest of northern hardwood forest. Forest Science 34, 744768.

Fahey, T.J., Bledsoe, C.S., Day, F.P., Ruess, R.W., Smucker, J.M., 1999. Fine root production and demography. In: Robertson, G.P., Bledsoe, C.S., Coleman, C., Sollins, P. (Eds.), Soils methods for long-term ecological research. Oxford University Press, New York, pp. 437-455.

Fairley, R.I., Alexander, I.J., 1985. Methods of calculating fine root production in forests. In: Fitter, A.H., Atkinson, D., Read, D.J.,, (Eds.), Ecological interactions in soil, plants, microbes and animals. Blackwell Science Publ., Oxford, pp. 37-42.

Graefe, S., Hertel, D., Leuschner Ch. 2008 Estimating fine root turnover in tropical forests along an elevational transect using minirhizotrons. Biotropica doi:10.1111/j.17447429.2008.00419.x.

Gower, S.T., Vogt, K.A., Grier, C.C., 1992. Carbon dynamics of Rocky-Mountain DouglasFir - influence of water and nutrient availability. Ecological Monographs 62, 43-65.

Hafkenscheid, R.L.L.J., 2000. Hydrology and biogeochemistry of tropical montane rain forests of contrasting stature in the Blue Mountains, Jamaica. Dissertation Universiteit Amsterdam. pp. 302.

Hendrick, R.L., Pregitzer, K.S., 1992. Spatial variation in tree root distribution and growth associated with minirhizotrons. Plant and Soil 143, 283-288.

Hendrick, R.L., Pregitzer, K.S., 1996. Applications of minirhizotrons to understand root function in forests and other natural ecosystems. Plant and Soil 185, 293-304.

Hendricks, J.J., Nadelhoffer, K.J., Aber, J.D., 1993. Assessing the role of fine roots in carbon and nutrient cycling. Trends in Ecology \& Evolution 8, 174-178.

Hendricks, J.J., Hendrick, R.L., Wilson, C.A., Mitchell, R.J., Pecot, S.D., Guo, D.L., 2006. Assessing the patterns and controls of fine root dynamics: an empirical test and methodological review. Journal of Ecology 94, 40-57.

Hertel, D., 1999. Das Feinwurzelsystem von Rein- und Mischbeständen der Rotbuche: Struktur, Dynamik und interspezifische Konkurrenz. Dissertationes Botanicae 317, 1184.

Hertel, D., Leuschner, C., 2002. A comparison of four different fine root production estimates with ecosystem carbon balance data in a Fagus-Quercus mixed forest. Plant and Soil 239, 237-251.

Hertel, D. Leuschner, C., Hölscher, D. 2003. Size and structure of fine root system in oldgrowth and secondary tropical montane forests (Costa Rica). Biotropica 35, 143-153.

Hertel, D., Leuschner, C., (in press) Fine root mass and fine root production in tropical moist forests as dependent on soil, climate and elevation. In: Bruijnzeel L.E., Juvik,J.O. (Eds.), Mountains in the mist: Science for Conserving and Managing tropical montane cloud forests. Hawaii University Press.

Hue, N.V., Craddock, G.R., Adams, F., 1986. Effect of organic-acids on aluminum toxicity in subsoils. Soil Science Society of America Journal 50, 28-34. 
Illig, J., Schatz, H., Scheu, S., Maraun M. 2008. Decomposition and colonization by microarthropods of two litter types in a tropical montane rain forest in southern Ecuador. Journal of Tropical Ecology 24: 157-167.

Iost, S., 2007. Soil respiration, microbial respiration and mineralization in soils of montane rainforests of Southern Ecuador: influence of altitude. Dissertation, Technical University of Dresden, Germany, pp. 171.

Kitayama, K., Aiba, S.-I., 2002. Ecosystem structure and productivity of tropical rain forests along altitudinal gradients with contrasting soil phosphorus pools on Mount Kinabalu, Borneo. Journal of Ecology 90, 37-51.

Krashevska, V., Bonkowski, M., Maraun, M., Ruess, L., Kandeler, E., Scheu, S. 2008. Microorganisms as driving factors for the community structure of testate amoebae along an altitudinal transect in tropical mountain rain forests. Soil Biol Biochem 40: 2427-2433.

Kurz, W.A., Kimmins, J.P., 1987. Analysis of some sources of error in methods used to determine fine root production in forest ecosystems - a simulation approach. Canadian Journal of Forest Research 17, 909-912.

Lauenroth, W.K., 2000. Methods of estimating belowground net primary production. In: Sala, O.E., Jackson, R.B., Mooney, H.A., Howarth, R.W. (Eds.), Methods in ecosystem science. Springer Verlag, New York, pp. 58-71.

Leuschner, C., Hertel, D., Coners, H., Büttner, V., 2001. Root competition between beech and oak: a hypothesis. Oecologia 126, 276-284.

Majdi, H., 1996. Root sampling methods - applications and limitation of the minirhizotron technique. Plant and Soil 185, 255-258.

Maraun, M., Illig, J., Sandman, D., Krashevskaya, V., Norton, R.A., Scheu, S., 2008. Soil fauna. In: Beck, E., Bendix, J., Kottke, I., Makeschin, F., Mosandl, R. (Eds.), Gradients in a tropical mountain ecosystem of Ecuador. Springer Verlag, Berlin, Heidelberg, Ecological Studies 198, 181-192.

McClaugherty, C.A., Aber, J.D., Melillo, J.M., 1982. The role of fine roots in the organic matter and nitrogen budgets of two forested ecosystems. Ecology 63, 1481-1490.

Moser, G., Hertel, D., Leuschner, C., 2007. Altitudinal change in LAI and stand leaf biomass in tropical montane forests - a transect study in Ecuador and a pan-tropical meta-analysis. Ecosystems 10, 924-935.

Moser, G., Röderstein, M., Soethe, N., Hertel, D., Leuschner, C., 2008. Altitudinal changes in stand structure and biomass allocation of tropical mountain forests in relation to microclimate and soil chemistry. In: Beck, E., Bendix, J., Kottke, I., Makeschin, F., Mosandl, R. (Eds.), Gradients in a tropical mountain ecosystem of Ecuador. Springer Verlag, Berlin, Heidelberg, Ecological Studies 198, 229-242.

Nadelhoffer, K.J., 2000. The potential effects of nitrogen deposition on fine-root production in forest ecosystems. New Phytologist 147, 131-139.

Nadelhoffer, K.J., Raich, J.W., 1992. Fine root production estimates and belowground carbon allocation in forest ecosystems. Ecology 73, 1139-1147.

Northup, R.R., Dahlgren, R.A., Yu, Z.S., 1995. Intraspecific variation of conifer phenolic concentration on a marine terrace soil acidity gradient - a new interpretation. Plant and Soil 171, 255-262.

Persson, H., 1978. Root dynamics in a young Scots pine stand in Central Sweden. Oikos 30, 508-519.

Persson, H., 1980. Fine-root dynamics in a Scots pine stand with and without near optimum nutrient and water regimes. Suecica 68, 101-110.

Powell, S.W., Day, F.P., 1991. Root production in four communities in the great dismal swamp. American Journal of Botany 78, 288-297. 
Publicover, D.A., Vogt, K.A., 1993. A comparison of methods for estimating forest fine root production with respect to sources of error. Canadian Journal of Forest Research 23, 1179-1186.

Raich, J.W., Russell, A.E., Vitousek, P.M. 1997. Primary productivity and ecosystem development along an elevational gradient on Mauna Loa, Hawai'i. Ecology 78, 707721.

Richter, M., Diertl, K.-H., Peters, T., Bussmann, R., 2008. Vegetation structures and ecological features of the upper timberline ecotone. In: Beck, E., Bendix, J., Kottke, I., Makeschin, F., Mosandl, R. (Eds.), Gradients in a tropical mountain ecosystem of Ecuador. Springer Verlag, Berlin, Heidelberg. Ecological Studies 198, 123-135.

Sala,O.E., Biondini,M.E., Lauenroth,W.K.. 1988. Bias in estimates of primary production: an analytical solution. Ecological Modelling 44, 43-55.

Santantonio, D., Grace, J.C., 1987. Estimating fine-root production and turnover from biomass and decomposition data: a compartment-flow model. Canadian Journal of Forest Research 17, 900-908.

Scheu, S., Illig, J., Eissfeller, V., Krashevska, V., Sandmann, D., Maraun, M. 2008. The soil fauna of a tropical mountain rainforest in southern Ecuador: structure and functioning. In: Gradstein SR, Homeier J, Gansert D (eds) The tropical mountain forest - patterns and processes in a biodiversity hotspot. Biodiversity and Ecology Series 2. Universitätsverlag Göttingen, Germany, pp. 79-98.

Singh, J.S., Lauenroth, W.K., Hunt, H.W., Swift, D.M., 1984. Bias and random errors in estimators of net root production - a simulation approach. Ecology 65, 1760-1764.

Steele, S.J., Gower, S.T., Vogel, J.G., Norman, J.M., 1997. Root mass, net primary production and turnover in aspen, jack pine and black spruce forests in Saskatchewan and Manitoba, Canada. Tree Physiology 17, 577-587.

van Praag, H.J., Sougnez-Remy, S., Weissen, F., Carletti, G., 1988. Root turnover in a beech and a spruce stand of the Belgian Ardennes. Plant and Soil 105, 87-103.

Vogt, K.A., Persson, H., Measuring growth and development of roots. 1991. In: Lassoie, J.P., Hinckley, Th.M. (Eds.), Techniques and approaches in forest tree ecophysiology. CRC Press, Florida, Boca, Ratas, Florida, pp. 477-501.

Vogt, K.A., Vogt, D.J., Bloomfield, J., 1998. Analysis of some direct and indirect methods for estimation root biomass and production of forests at an ecosystem level. Plant and Soil 200, 71-89.

Wang, H.Q., Hall, C.A.S., Scatena, F.N., Fetcher, N., Wu, W., 2003. Modeling the spatial and temporal variability in climate and primary productivity across the Luquillo Mountains, Puerto Rico. Forest Ecology and Management 179, 69-94.

Weaver, P.L., Murphy, P.G., 1990. Forest structure and productivity in Puerto-Rico Luquillo Mountains. Biotropica 22, 69-82.

Zach A., V. Horna and Ch. Leuschner 2008. Elevational changes in woody tissue CO2 efflux rates in a tropical mountain rainforest in southern Ecuador. Tree Physiology 28:67-74. 



\section{7 \\ S Y N T H E S I S}

\subsection{SUMMARY OF THE PRESENT FINDINGS}

Recently, Clark (2007) reviewed the state of knowledge on biomass and productivity of tropical rainforests and their responses to climate change. The author pointed at some advances but also at big data gaps, including altitudinal gradient studies. Espeleta \& Clark (2007) stressed that data on belowground production in tropical forests is still very limited but of paramount interest to predict future reactions of the carbon cycle of tropical forests to climate change. In Chapter 1, a number of hypotheses and questions about the reasons of altitudinal changes in forest structure, biomass allocation and net primary production were formulated. This section tries to assess these hypotheses in the light of the present findings or reviews the existing knowledge if definite answers are still missing.

\subsection{RESULTS ON BIOMASS ALLOCATION}

Biomass and annual production data of all collected above- and belowground compartments are listed in Table 7.1. Total tree biomass declined from 317.2 to $174.9 \mathrm{Mg}$ $\mathrm{ha}^{-1}$ between 1050 and $3060 \mathrm{~m}$ elevation, showing its absolute minimum of $145.0 \mathrm{Mg} \mathrm{ha}^{-1}$ at $2380 \mathrm{~m}$ a.s.1. where stem density was much lower than at the uppermost plot but mean tree height was already noticeable below $10 \mathrm{~m}$. Aboveground biomass (AGB) decreased twofold along the gradient, although leaf biomass peaked at mid-elevation. At a lower magnitude belowground biomass (BGB) increased twofold with rather similar amounts between 1050 and $2340 \mathrm{~m}$, but a steep ascend to $3060 \mathrm{~m}$. The percentage of fine roots at $1050 \mathrm{~m}$ on total root biomass was $8.3 \%$ and rose to $17.3 \%$ at 3060 m elevation.

Different fractions of aboveground biomass production were not mentioned in the first six chapters. For example, the fine litter fractions with reproductive organs, twigs, and non-tree fine litter, which were collected parallel to leaf litter (see Chap.5). The first two showed significant decreasing trends with elevation. Non-tree fine litter peaked at mid-elevation, where bamboo in the understorey produced high amounts of leaf litter. Further, aboveground wood production was not yet included in the discussion. Stem diameter increment was measured from May 2003 to July 2004 in three months intervals with dendrometer tapes $(n=20)$. Using the allometric equation of Chave et al. (2005), the aboveground wood biomass increment was calculated for a one-year period. The aboveground wood production decreased 20.1-fold between 1000 and $3000 \mathrm{~m}$ elevation, and consequently total aboveground tree production $\left(\mathrm{ANPP}_{\text {tree }}\right)$ decreased 4.2 -fold along the slope. Coarse and large root production was highest on the most wind-exposed plots 2 and 5. Taking coarse root production and fine root production derived from minirhizotron technique together a 4.2-fold increase in total belowground tree production $\left(\mathrm{BNPP}_{\text {tree }}\right)$ was estimated, which counterbalanced the aboveground production decrease. The total estimates of NPP for the five studied forest sites therefore revealed very similar amounts of about 13 $\mathrm{Mg} \mathrm{ha}^{-1} \mathrm{yr}^{-1}$, with the only exception of a lower value of $7.88 \mathrm{Mg} \mathrm{ha}^{-1} \mathrm{yr}^{-1}$ at $2340 \mathrm{~m}$ elevation.

Results of regression analyses of biomass and productivity on environmental variables are given in Table 7.2, those on forest structure and leaf trait parameters in Table 7.3. The 
decrease of AGB between 1050 and 3060 m elevation was not continuous but gave a significant trend on the decline of aboveground wood biomass, while leaf biomass was not correlated with elevation. Although LAI decreased more or less continuously along the slope, leaf biomass did not and had its maximum at $1890 \mathrm{~m}$ a.s.l. due to a large reduction of specific leaf area (SLA) in the lowermost half of the gradient (Chap.5, Moser et al. 2007).

Tab. 7.1: Above- and belowground biomass and productivity fractions at the five Ecuadorian study plots.

\begin{tabular}{|c|c|c|c|c|c|}
\hline Plot & 1 & 2 & 3 & 4 & 5 \\
\hline Elevation & $1050 \mathrm{~m}$ & $1540 \mathrm{~m}$ & $1890 \mathrm{~m}$ & $2380 \mathrm{~m}$ & $3060 \mathrm{~m}$ \\
\hline \multicolumn{6}{|l|}{ Biomass } \\
\hline Leaves & $6.82 \pm 0.44^{\mathrm{a}}$ & $7.99 \pm 0.55^{b}$ & $9.74 \pm 0.83^{b}$ & $5.25 \pm 0.43^{\mathrm{c}}$ & $3.64 \pm 0.29^{d}$ \\
\hline Wood & 278.3 & 159.5 & 163.2 & 94.6 & 108.6 \\
\hline AGB & 285.1 & 167.5 & 173.0 & 99.8 & 112.2 \\
\hline Coarse + large roots & $29.4 \pm 8.44^{\mathrm{ab}}$ & $30.7 \pm 8.16^{\mathrm{a}}$ & $19.9 \pm 2.64^{b}$ & $32.9 \pm 5.67^{\mathrm{a}}$ & $51.9 \pm 4.73^{\mathrm{c}}$ \\
\hline Fine roots & $2.66 \pm 0.27^{\mathrm{a}}$ & $5.62 \pm 0.43^{b}$ & $6.18 \pm 0.34^{\mathrm{b}}$ & $6.29 \pm 0.57^{b}$ & $10.84 \pm 0.58^{\mathrm{c}}$ \\
\hline $\mathrm{BGB}$ & 32.1 & 36.3 & 26.1 & 39.2 & 62.7 \\
\hline Total tree biomass & 317.2 & 203.8 & 198.7 & 145.0 & 174.9 \\
\hline \multicolumn{6}{|l|}{ Production } \\
\hline Leaves & $5.05 \pm 0.33^{\mathrm{a}}$ & $5.06 \pm 0.35^{a}$ & $4.96 \pm 0.43^{\mathrm{a}}$ & $2.64 \pm 0.22^{b}$ & $1.79 \pm 0.15^{\mathrm{c}}$ \\
\hline Reproductive organs & $0.91 \pm 0.10^{\mathrm{a}}$ & $0.43 \pm 0.11^{\mathrm{b}}$ & $0.36 \pm 0.14^{b}$ & $0.11 \pm 0.06^{c}$ & $0.07 \pm 0.07^{c}$ \\
\hline Twigs & $1.13 \pm 0.11^{\mathrm{a}}$ & $0.93 \pm 0.07^{\mathrm{a}}$ & $0.88 \pm 0.06^{\mathrm{a}}$ & $0.39 \pm 0.02^{b}$ & $0.39 \pm 0.01^{b}$ \\
\hline Total tree fine litter & $7.10 \pm 0.46^{\mathrm{a}}$ & $6.39 \pm 0.44^{\mathrm{a}}$ & $6.20 \pm 0.53^{\mathrm{a}}$ & $3.17 \pm 0.25^{\mathrm{b}}$ & $2.25 \pm 0.17^{c}$ \\
\hline Wood & 2.82 & 1.58 & 0.87 & 0.22 & 0.14 \\
\hline Tree ANPP & 9.91 & 7.97 & 7.07 & 3.39 & 2.39 \\
\hline Non-tree fine litter & $0.69 \pm 0.12^{\mathrm{ac}}$ & $0.92 \pm 0.13^{\mathrm{a}}$ & $2.14 \pm 0.11^{\mathrm{b}}$ & $0.51 \pm 0.11^{\mathrm{c}}$ & $0.28 \pm 0.08^{d}$ \\
\hline Total ANPP & 10.60 & 8.89 & 9.21 & 3.90 & 2.67 \\
\hline Coarse + large roots & $0.17 \pm 0.04^{\mathrm{a}}$ & $0.79 \pm 0.14^{\mathrm{b}}$ & $0.23 \pm 0.03^{\mathrm{a}}$ & $0.23 \pm 0.04^{\mathrm{a}}$ & $0.89 \pm 0.08^{b}$ \\
\hline Fine roots & $2.28 \pm 0.20^{\mathrm{a}}$ & $3.16 \pm 0.51^{\mathrm{ab}}$ & $2.97 \pm 0.31^{\mathrm{ab}}$ & $3.72 \pm 0.50^{\mathrm{b}}$ & $9.40 \pm 1.32^{\mathrm{C}}$ \\
\hline Tree BNPP & 2.45 & 3.95 & 3.20 & 3.95 & 10.29 \\
\hline Tree NPP & 12.36 & 11.92 & 10.27 & 7.34 & 12.68 \\
\hline Total NPP & 13.05 & 12.84 & 12.41 & 7.85 & 12.96 \\
\hline
\end{tabular}

If possible means $\pm 1 \mathrm{SE}$ are given. Different letters indicate significant differences between the five study plots $(\mathrm{p}=0.05)$.

Leaf biomass was the only aboveground component, which was directly related to mean annual precipitation. Also $\mathrm{C} / \mathrm{N}$ ratio of the organic layer was significantly correlated with leaf biomass. No significant relationships were detected between leaf biomass and forest structure or leaf traits, except to LAI.

Temperature affected significantly total and woody aboveground biomass. Significant correlations between these biomass fractions were also found with vapour pressure deficit (VPD); total AGB was also related to soil moisture. The proton concentration derived from mineral soil $\mathrm{pH}$ showed no significant effects on aboveground biomass, while a close relationship between total and woody aboveground biomass and $\mathrm{C} / \mathrm{N}$ ratio of the organic layer did occur. Aboveground wood biomass and total AGB correlated with all parameters of forest structure and leaf traits tested here (mean stem height, mean DBH, stem density, 
LAI, SLA, leaf N-contents per dry mass and per area). Closest relations occurred with leaf $\mathrm{N}$-content per dry mass, mean DBH and SLA.

Coarse and large root biomass was not directly related to any tested environmental factor (wind speed data were not available for the forest sites), but correlated negatively with leaf biomass $\left(r^{2}=0.78, r^{2}\right.$ adj $\left.=0.70, p=0.023\right)$, LAI, leaf $\mathrm{N}$-content per area, and only weakly, but positively, with stem density. Fine root biomass correlated significantly with all environmental factors, except precipitation. Further significant relationships were found with stem height, $\mathrm{DBH}$, stem density and leaf $\mathrm{N}$-content per area. Total root biomass was the only biomass fraction that correlated with all seven tested environmental factors, closest with $\mathrm{C} / \mathrm{N}$ ratio and proton concentration. $\mathrm{DBH}$ and stem density, LAI and leaf $\mathrm{N}$-content per area significantly affected total root biomass.

Total tree biomass correlated with temperature, proton concentration of the mineral topsoil and $\mathrm{C} / \mathrm{N}$ ratio of the organic layer. All forest structure and leaf trait parameters showed significant relations with total tree biomass. Closest related were SLA, leaf Ncontent per dry mass and average stem height. The portion of belowground biomass on total tree biomass increased from 10.1 to $35.9 \%$ between the lowermost and the uppermost site.

The largest part to aboveground tree production $\left(\mathrm{ANPP}_{\text {tree}}\right)$ in all five forest stands contributed annual leaf production, which declined 2.7-fold along the gradient and correlated with all tested environmental factors. Leaf production also correlated with most parameters of forest structure and leaf traits, except mean DBH and SLA. Closest relationships occurred with LAI, leaf $\mathrm{N}$-contents and mean stem height.

The production of fruits, flowers and inflorescences declined 13-fold between $1050 \mathrm{~m}$ a.s.1. and $3060 \mathrm{~m}$ elevation. No significant correlation of reproductive litter fall was observed with annual precipitation and proton concentration. All other climatic and edaphic factors affected significantly the production of reproduction organs, strongest the $\mathrm{C} / \mathrm{N}$ ratio of the organic layer. Only with leaf N-content per area no significant relation was detected. Best correlations occurred with leaf N-content per dry mass, mean stem height and SLA.

Twig production declined 2.9-fold between site \#1 and 5 and correlated in a similar manner as leaf production did with all environmental factors tested, closest with VPD, soil moisture and annual precipitation.

At the three lowermost plots, wood increment, including the production of stem and branch wood, was responsible for the second largest part of $\mathrm{ANPP}_{\text {tree, }}$, falling below twig production at the two uppermost plots. The continuous 20.6-fold decline of aboveground wood production between 1050 and $3060 \mathrm{~m}$ elevation correlated well with all tested environmental factors, except annual precipitation and soil proton concentration. The strongest relationship of aboveground wood production was observed with mean air temperature and VPD. Aboveground wood production was significantly related to mean DBH, LAI and leaf N-content per dry mass, but closest to stem height and SLA.

Total $\mathrm{ANPP}_{\text {tree }}$ as the sum of aboveground wood and fine litter production declined 4.2fold and correlated significantly with all tested stand factors, strongest with vapour pressure deficit, volumetric soil water content, elevation and air temperature. Total aboveground production of trees was closely related to mean tree height, LAI and leaf N-content per dry mass, further to $\mathrm{DBH}$ and leaf $\mathrm{N}$-content per area.

Non-tree litter production including fallen live and dead epiphytes, cryptogam litter, bamboo litter and a small fraction of animal litter, mainly insects, and unidentified organic matter ("rest"), ranged between 2.14 and $0.28 \mathrm{Mg} \mathrm{ha}^{-1} \mathrm{yr}^{-1}$, showing its maximum at $1890 \mathrm{~m}$ a.s.1., Here bamboo occurred frequently in the understorey, producing $72 \%$ of total non-tree litter. Bamboo did not occur on the two lowermost sites and was producing only $14-25 \%$ of non-tree litter on the two uppermost sites. Non-tree litter production did not correlate with 


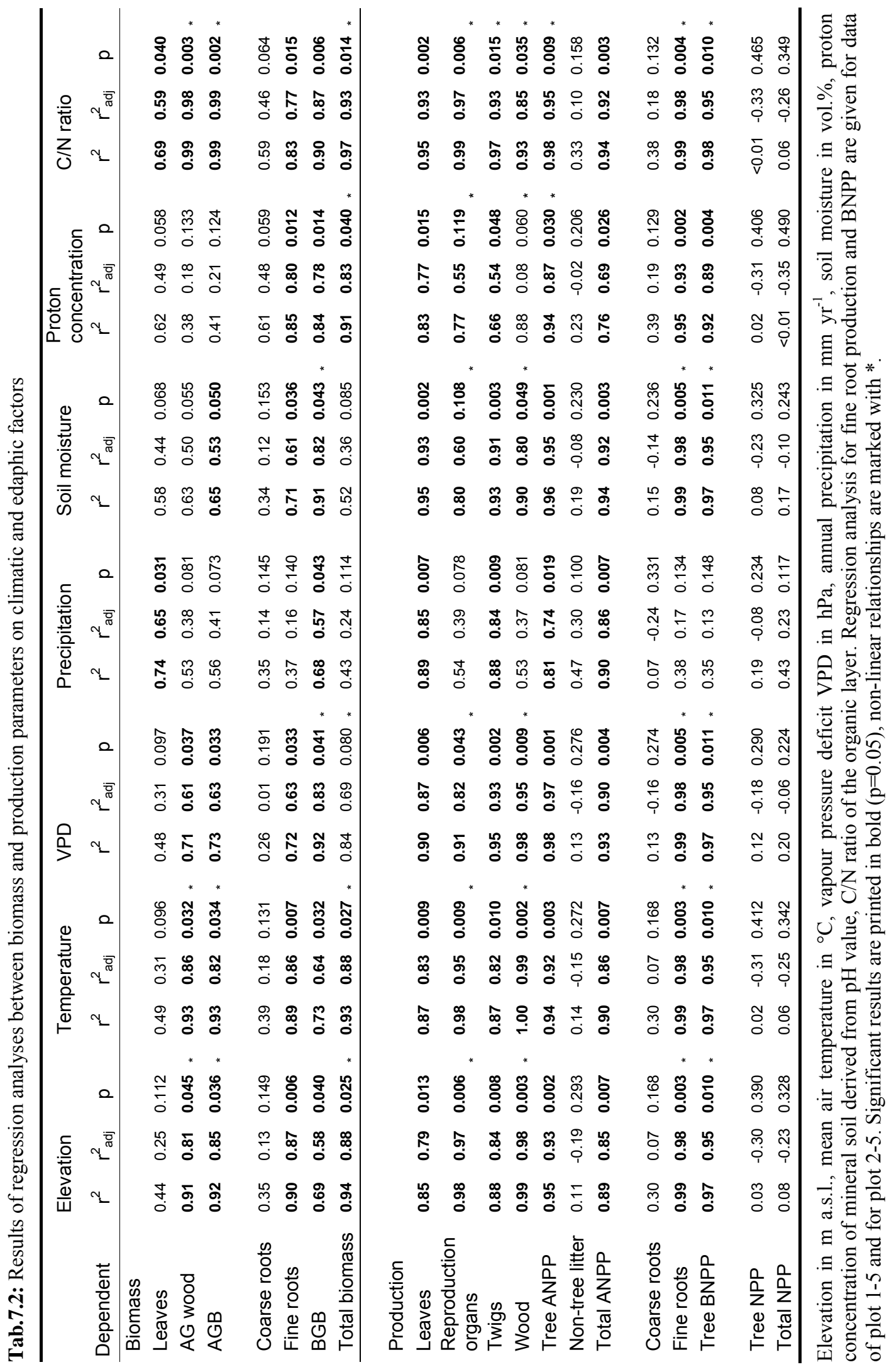




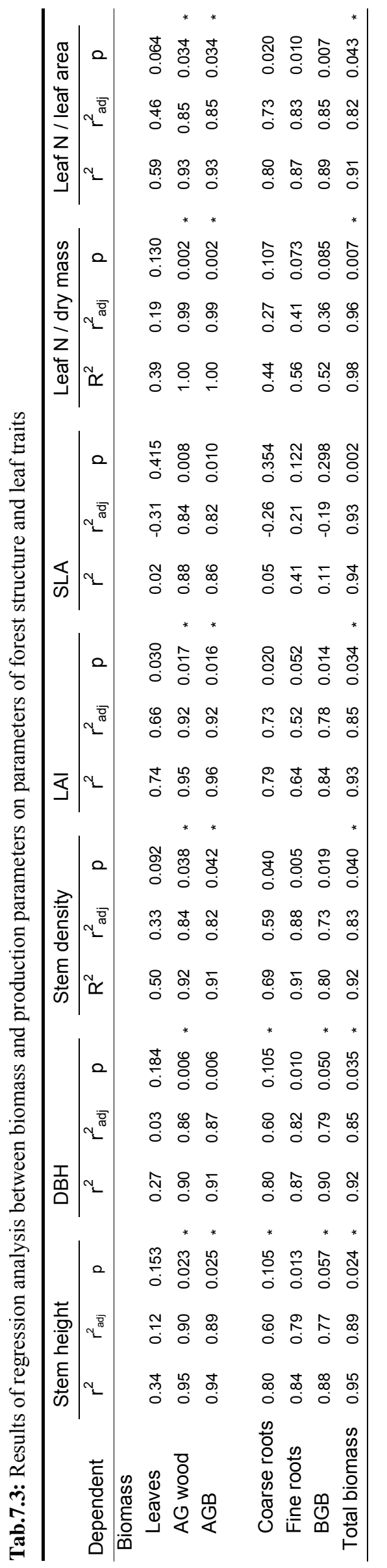

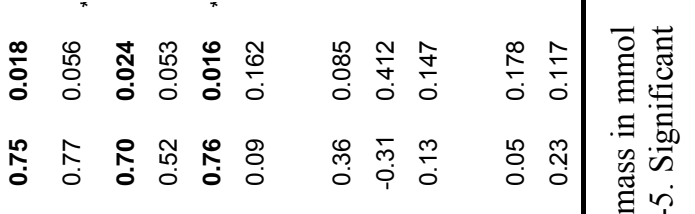

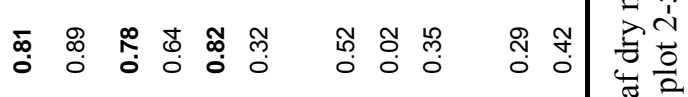

芯 :

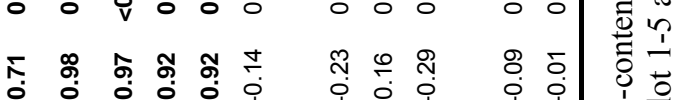

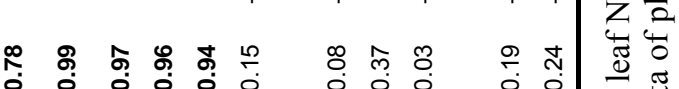

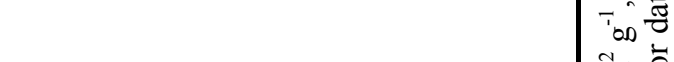

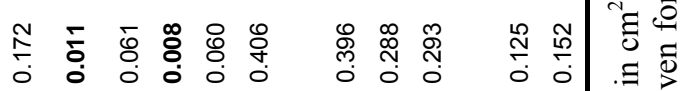
\&

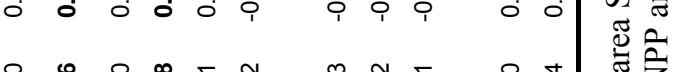
లి

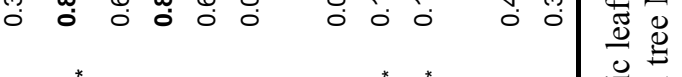

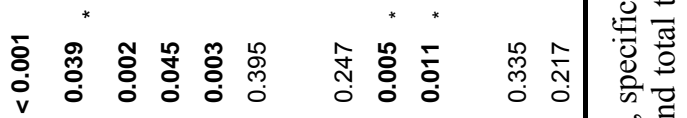

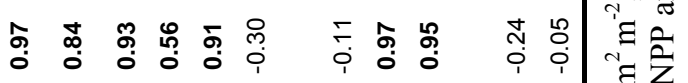

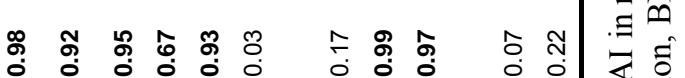

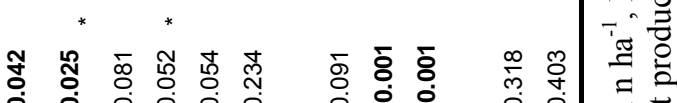

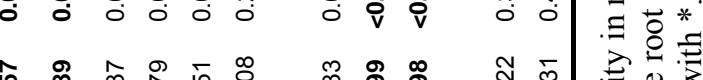

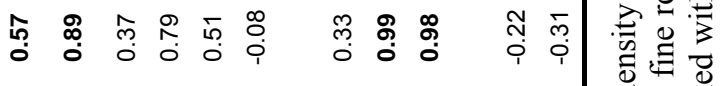
竞 范

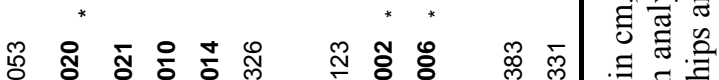
豋 范

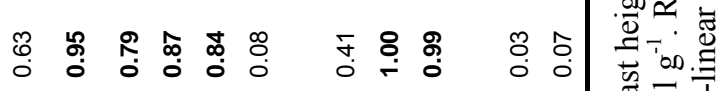
金

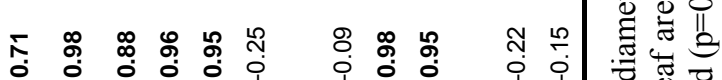

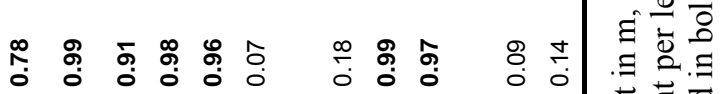

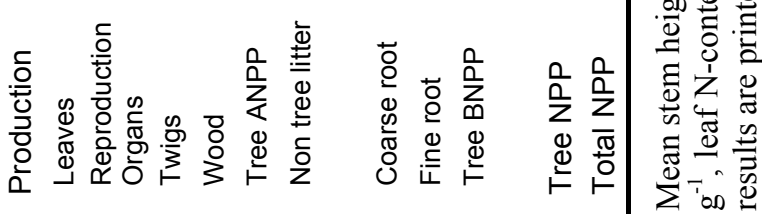


any of the environmental factors. The epiphyte litter and "rest" litter fraction featured significant relations with all climatic factors, cryptogam litter correlated only with coarse branch litter (data not shown), as it was most times directly connected to fallen branches.

Total ANPP, i.e. the sum of ANPP tree and non-tree litter production, revealed in a 4.0 -fold decrease along the gradient. Total ANPP was significantly affected by all tested climatic and edaphic parameters, with closest relations to $\mathrm{C} / \mathrm{N}$ ratio of the organic layer, mineral soil moisture and vapour pressure deficit.

Coarse and large root production showed highest values on the two most wind-exposed sites \#2 and \#5, 0.79 and $1.00 \mathrm{Mg} \mathrm{ha}^{-1} \mathrm{yr}^{-1}$ respectively, and was not affected by a single factor tested here (wind data were not available for the forest stands).

Fine root production derived from the minirhizotron approach showed a 4.1-fold exponential increase between 1050 and $3060 \mathrm{~m}$ elevation and correlated very well with all tested environmental factors, except precipitation. Closest relationship occurred with the soil proton concentration and temperature. Regression analysis with the parameters of forest structure and with LAI revealed also highly significant relationships, particularly with stem density.

Total root production $\left(\mathrm{BNPP}_{\text {tree }}\right)$ as the sum of fine, coarse and large root increment, increased exponentially (4.2-fold) with elevation. No correlation was found with precipitation, but close relationships occurred with all other climatic and edaphic factors, closest with soil proton concentration. Very strong correlations occurred with stem density, $\mathrm{DBH}$, stem height and LAI. The percentage of fine root production on total root production ranged between 80 and $93 \%$ and showed no trend along the gradient.

For all plots except site \#4, the resulting tree NPP was very similar (between 10.3 and 12.8 $\left.\mathrm{Mg} \mathrm{ha}^{-1} \mathrm{yr}^{-1}\right)$. At stand \#4, an absolute minimum of $7.4 \mathrm{Mg} \mathrm{ha}^{-1} \mathrm{yr}^{-1}$ was observed and therefore no altitudinal trend was detected. Adding non-tree fine litter did not considerably change this result. No single significant correlation occurred between tree and total NPP and the environmental factors or the forest structure and leaf trait parameters.

The portion of tree leaf production in total NPP ranged between 38 and $40 \%$ between 1050 and $1890 \mathrm{~m}$, and fell to $13.7 \%$ at $3060 \mathrm{~m}$ a.s.l. The contributions of aboveground wood increment to total NPP decreased exponentially with elevation from 21.6 to $1.1 \%$. Therefore, total ANPP accounted for $81.2 \%$ of total NPP at $1050 \mathrm{~m}$, but only for $20.4 \%$ at $3060 \mathrm{~m}$. The percentage of BNPP in total NPP increased inversely from 18.8 to $79.6 \%$. The portion of fine root production in total NPP increased from 17.5 to $90.4 \%$ along the elevation transect.

\subsection{DISCUSSION OF BIOMASS ALLOCATION PATTERNS}

As far as we know, data on above and/or belowground biomass were published only in very few studies along elevation gradients in tropical montane forests. Additional to our investigations we found three transect studies that determined aboveground biomass, containing data from two different transects in Hawaii (Raich et al. 1997), one in Puerto Rico (Weaver \& Murphy 1990, Wang et al. 2003) and two in Malaysia where also fine root biomass data were available (Kitayama \& Aiba 2002, see Fig.7.1). The trend of all six transect studies for aboveground biomass was very similar, showing significantly decreasing amounts with increasing elevation. Because of great variation of AGB at respective altitudes the overall trend was not significant.

The trends of aboveground productivity (wood, leaf or total production) of all tropical transects indicated a decreasing ANPP with increasing altitude, with weak, but significant, correlations for the wood and leaf production datasets. Astonishing was that AGB and also aboveground wood production at similar altitudes varied tremendously, while the variability of leaf production at respective elevations was rather small. 

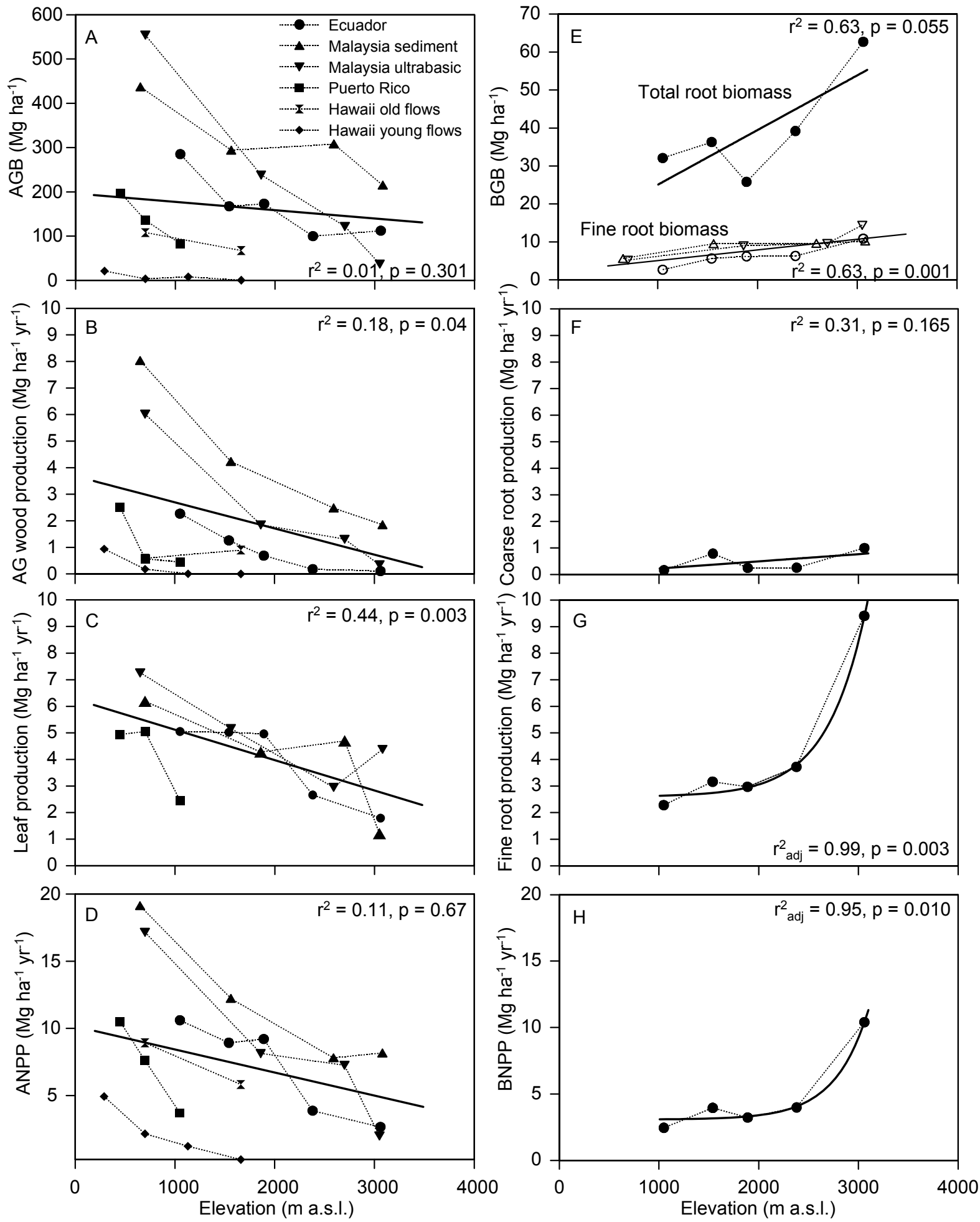

Figure 7.1: Comparison of data on above- (A-D) and belowground (E-H) fractions of biomass and production from published elevation gradient studies from all over the tropics. Data points from single transects are connected with dotted lines. Given are results from linear and simple non-linear regression analyses with continuous bold trend lines. For belowground biomass (BGB) regression analysis was conducted separately for data on total and on fine root biomass. $\mathrm{r}^{2}$ adj refers to non-linear correlations between fine root and total root production (BNPP). Ecuador - own data; Malaysia Kitayama \& Aiba (2002); Puerto Rico - Weaver \& Murphy (1990) and Wang et al. (2003); Hawaii - Raich et al. (1997). 
The few data on belowground biomass along elevation gradients in tropical montane forests show increasing amounts of root biomass upslope. For total root biomass along elevation gradients only our data from Ecuador were available. Also in single plot studies, BGB has only rarely been determined, in the neotropics only at 16 sites. The positive relationship of belowground biomass and elevation for these 16 forest stands was significant only at $\mathrm{p}=0.076\left(\mathrm{r}^{2}=0.13\right)$, but the data indicate a positive trend with elevation (see Chapt.3). From Mt. Kinabalu, Malaysia, at least fine root biomass data set was reported (Kitayama \& Aiba 2002), with the values in a similar range as found in Ecuador. A positive trend of fine root biomass with elevation has also been documented in a comprehensive meta-analysis of fine root data of paleo- and neotropical forest stands by Hertel \& Leuschner (2008).

The root production data along the elevation gradient in Ecuador are unique and not available for any other transect study or single plot study at high elevation. Comparison to other case studies and a discussion of possible general trends in mountain transect therefore remain difficult. Since the sequential coring approach based on the maximum-minimum calculation revealed an unrealistic tenfold increase of annual fine root production from about 2 to $22 \mathrm{Mg} \mathrm{ha}^{-1} \mathrm{yr}^{-1}$ between 1000 and $3000 \mathrm{~m}$, the minirhizotron technique, with its direct observation of fine root growth appeared to yield the best estimate. A remaining uncertainty of the applied minirhizotron technique is, whether the fine root turnover rate determined in the uppermost $10 \mathrm{~cm}$ of the organic layer can be extrapolated to the total soil profile at $3060 \mathrm{~m}$ a.s.1., which consists of about $48 \mathrm{~cm}$ of organic layer plus $20 \mathrm{~cm}$ of mineral soil. Close to the soil surface, the nutrient input from the decay of aboveground litter should be highest, and the oxygen supply in the often waterlogged soil should also be higher in upper than lower horizons. Therefore, it seems likely that fine root turnover in the uppermost $10 \mathrm{~cm}$, stimulated by a higher nutrient supply rate, was higher than in deeper soil layers. This could have caused an overestimation of the annual fine root production in particular at the uppermost site, explaining partly the very steep increase in estimated fine root production between 2340 and $3060 \mathrm{~m}$.

Net primary production (NPP) (i.e. the sum of above- and belowground tree production using the results of the minirhizotron approach) remained more or less stable along the transect between 1050 and $3060 \mathrm{~m}$, except for a low value at $2340 \mathrm{~m}$. A constant NPP with elevation is not unrealistic if the evidence for a constant or only slightly decreasing net carbon gain between 1000 and $3000 \mathrm{~m}$ is inspected

While LAI decreased 2.7-fold,

i) photosynthetically active radiation (PhAR) stayed more or less constant between 1000 and $3000 \mathrm{~m}$ (Unger unpubl.),

ii) area-related leaf $\mathrm{N}$-content changed only little, and thus it is likely that the arearelated photosynthetic capacity may have decreased only slightly with elevation,

iii) the canopy structure of the forest at $1050 \mathrm{~m}$ allowed only a small portion of leaves to receive full radiation, while a great amount of shade leaves thrived in the deep shade; the stunted tree canopies at $3060 \mathrm{~m}$ permitted nearly all leaves access to full sun light, and

iv) the respiration losses of roots and woody tissues decreased upslope (Iost 2007, Zach et al. 2008), which may have compensated for the decrease in photosynthetic capacity due to the LAI reduction.

Therefore, it is not unlikely that NPP changed only little between 1000 and $3000 \mathrm{~m}$ even if canopy carbon gain decreases upslope to a certain extent.

Clark et al. (2001a \& b) pointed out that so far no single study has achieved the aim to measure all different components of net primary production in tropical forests completely. 
Despite great efforts to measure the above- and belowground biomass and production as complete as possible, we were not able to cover all relevant components of the carbon balance. Components not included are above- and belowground herbivory, rhizodeposition and C-flux to mycorrhiza, emissions of volatile organic compounds and photosynthetic activity of the sun canopy.

Following Clark et al. (2002a) we tried to estimate these missing components of NPP. Moreover, we estimated possible errors for the measured components at all five Ecuadorian study plots (see Appendix, Tab.8.1). The estimation of possible biases in the NPP data of the Ecuadorian transect related to 21 parameters revealed that the potential errors greater at low elevation than at high elevation (Fig.7.2). According to this error estimation, a slight decrease in NPP with elevation is likely.

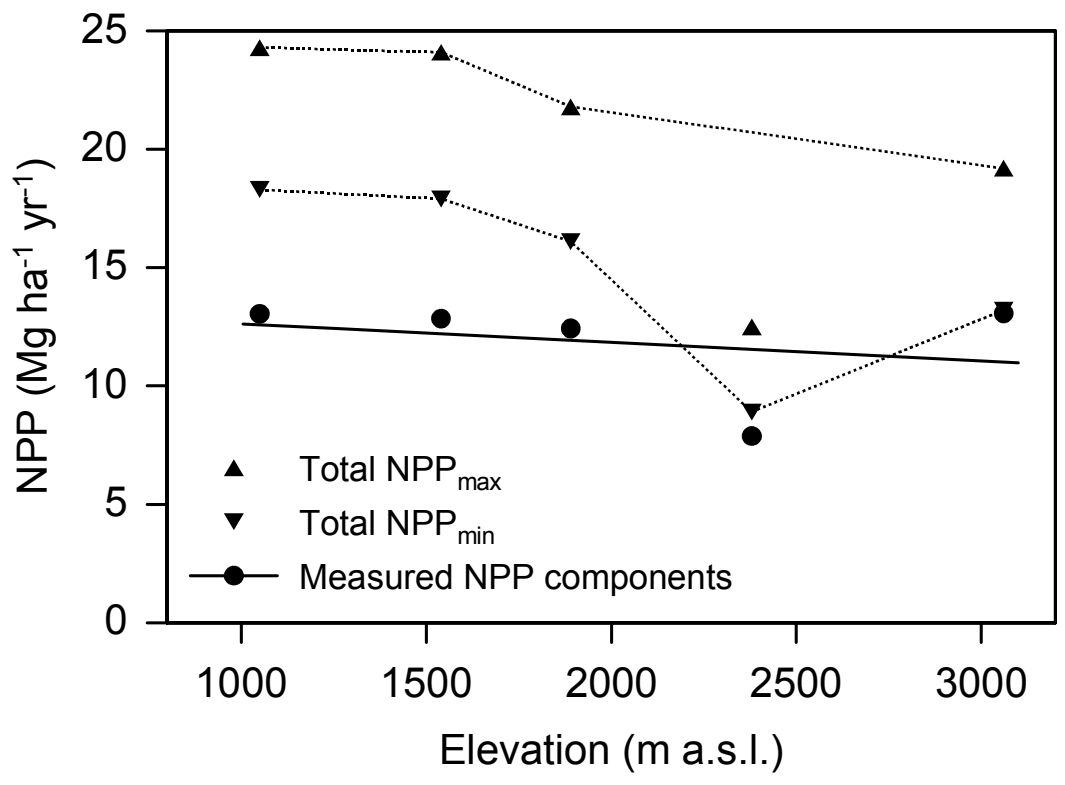

Fig.7.2: Error estimation of total ecosystem NPP values. Given is the measured NPP of the Ecuadorian study sites as the sum of aboveground fine litter and wood production, and belowground fine, coarse and large root production $\left(\mathrm{r}^{2}=0.14, \mathrm{p}=0.269\right)$. Based on these data, a relative error estimation after Clark et al. (2001b) including 21 parameters was conducted (see Appendix, Tab.8.1), and the estimated range of potential maxima and minima of total ecosystem NPP is given.

The tremendous 4.9-fold increase in the root/shoot biomass ratio and the 18.9-fold increase in root/shoot production ratio of trees in the Ecuador transect between 1050 and $3060 \mathrm{~m}$ stresses the large carbon allocation shift from aboveground to belowground organs (Chapt. 3 and 4). Bruijnzeel \& Veneklaas (1998) listed six categories of hypotheses that have been invoked to explain the unique structural and functional characteristics of tropical montane cloud forests: (1) periodic water shortage, (2) saturated soils and impeded root respiration, (3) reduced leaf temperature and photosynthesis, (4) limited nutrient uptake, (5) exposure to strong winds, and (6) presence of high concentration of phenolic compounds. (7) High doses of ultraviolet-B light could also play a role (Flenley 1995).

The availability of water was not decreasing with altitude; on the contrary, soil moisture was increasing linearly and caused waterlogging at high elevation (see Chapter 2). Decomposition rates under such wet and cool conditions slow down (Vitousek et al. 1994) and lead to humus accumulation and high $\mathrm{C} / \mathrm{N}$ ratios of the organic layer. This effect is enhanced by already higher $\mathrm{C} / \mathrm{N}$ ratios of leaf and root litter at high elevation (data not shown). The decreasing decomposition rates of roots (see Chapter 6) and aboveground fine 
litter (Iost 2007) along the South Ecuadorian transect are reflected in the decreasing soil respiration rate with increasing elevation (Iost 2007). Data on the soil mesofauna in the study area by Maraun et al. (2008) indicated generally very low abundances of primary decomposers, which decreased with elevation.

Additional data on root respiration in the study plots in South Ecuador showed that the total root biomass at $3060 \mathrm{~m}\left(62.7 \mathrm{Mg} \mathrm{ha}^{-1}\right)$ had a lower respiratory activity than the 32.1 $\mathrm{Mg} \mathrm{ha}^{-1}$ of root biomass at $1050 \mathrm{~m}$ elevation (Iost 2007). Low root respiration rates may indicate low specific nutrient uptake rates, caused by cool temperatures and partial anoxia in the soils.

Very low transpiration rates at high elevation may have contributed to low nutrient uptake rates. As shown in Chapter 2, the mean daily maximum of VPD at $3060 \mathrm{~m}$ ranged in 10 of 12 months only around $2 \mathrm{haP}$. Additional data on xylem vessel size in roots and twigs along this elevation transect indicated decreasing maximal hydraulic conductivities (B. Schuldt, unpubl.). Data from slope forests and stunted elfin forests within the RBSF revealed decreasing transpiration rates upslope (Küppers et al. 2008).

In his study on the stunted montane forests in Jamaica, Hafkenscheid (2000) concluded that not the total soil nutrient content may be the critical limiting factor of tree growth, but the nutrient uptake ability of the trees. He found that high polyphenol contents in the soil water can be accompanied by low concentrations of inorganic $\mathrm{N}$ as well as by high organic $\mathrm{N}, \mathrm{Al}^{3+}$ and $\mathrm{H}^{+}$contents. According to Northup et al. (1995), this soil solution composition reduces nitrate leaching losses with drainage water because $\mathrm{NO}_{3}{ }^{-}$is bound in complexes with polyphenols. Under such conditions, the concentration of dissolved organic N (DON) in the soil water will increase and that of $\mathrm{NH}_{4}{ }^{+}$and $\mathrm{NO}_{3}{ }^{-}$will decrease. Hafkenscheid (2000) stated that the high concentration of phenols in the topsoil water in the stunted forest in Jamaica probably reflect exudation from fine roots rather than leaching from leaf litter. More or less constant phenol concentrations in living leaves (M. Unger unpubl.) and increasing concentration of soluble phenols in the fine roots with increasing elevation (see Chapt.6, Moser et al. 2007) seem to support this hypothesis. A higher synthesis of phenols by the trees in stunted forests may serve two purposes, to conserve $\mathrm{N}$ by reducing leaching losses of mobile $\mathrm{NO}_{3}{ }^{-}$and to ameliorate Al-toxicity by complexation (Hue et al. 1986). However, these advantages are contrasted by the "costs" of a retarded decomposition, and the increased belowground production of secondary metabolites is achieved at the expense of aboveground productivity and thus tree height (Bruijnzeel \& Veneklaas 1998).

The nutrient limitation of tree growth at the uppermost Ecuadorian study site is also visible in the specific morphology of leaves and roots: specific leaf area and specific root area decrease with increasing elevation (Moser et al. 2007; root data not shown), and so did also the mass-based $\mathrm{N}$ concentrations in leaves and roots. The construction costs of thick leaves and roots are reduced as the lifespan is extended (Aerts \& Van der Peijl 1993). Kitayama \& Aiba (2002) also found a higher nutrient use efficiency of the canopy trees at high elevations on Mt. Kinabalu, Malaysia.

For the South Ecuadorian study region with its relatively low tree line in the so called Huancabamba depression, it was assumed that the altitudinal position of the upper tree line is modulated by high soil moisture and especially high wind velocities (Richter et al. 2008). The intersection point of the trend lines for AGB and BGB coincides very well with the actual position of the tree line (Fig.7.3), with AGB decreasing and fine, coarse and large root biomass increasing upwards. We hypothesize that at the alpine tree line in Ecuador a combination of an increasing limitation of nutrient supply and uptake and the necessity of a strong anchorage due to high wind loads (Soethe et al. 2006a \& b) is consuming a large part of the available carbon and nutrient resources, thereby limiting aboveground growth. 

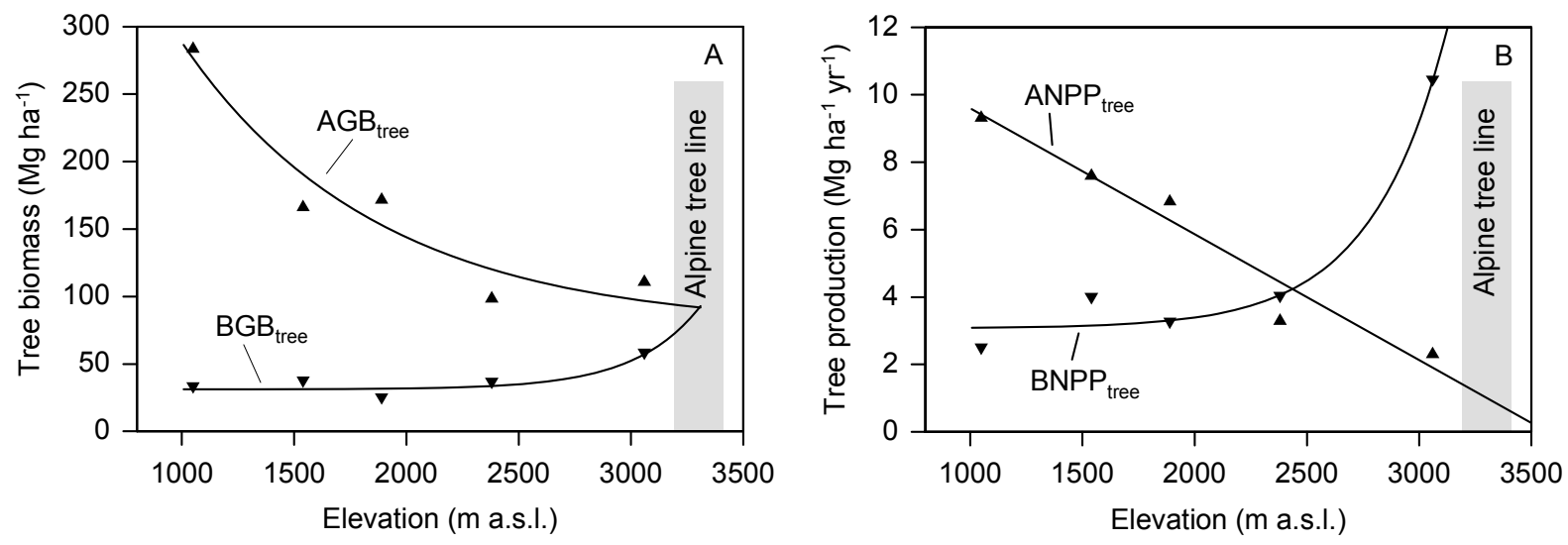

Figure 7.3: Above- and belowground trends of tree biomass and productivity. A) The intersection point of the AGB and BGB curves coincides very well with the position of the alpine tree line. B) Trend lines of ANPP and BNPP versus the actual position of the alpine tree line at 3200-3400 m elevation.

\subsection{FinAL CONCLUSIONS}

The four main hypotheses of this study, as formulated in Chapter 1, were as follows: (i) tree NPP decreases only slightly between 1000 and $3000 \mathrm{~m}$ a.s.1., (ii) decreasing aboveground tree production is mainly caused by an allocation shift to the belowground compartment, (iii) the relative and absolute amount of fine root production increases with elevation, and (iv) the main reason for the carbon allocation shift is a changing resource limitation of plant growth, from predominant light limitation at low elevation to increasing limitation of nutrient availability at high elevation.

The estimated NPP between 1000 and $3000 \mathrm{~m}$ elevation, i.e. the sum of aboveground fine litter production, wood increment, and belowground production of fine, coarse and large roots, did not show a significant decline, but stayed more or less constant with elevation. Thus, the first hypothesis was confirmed by the results of this study, even if it is kept in mind that plant respiration, root exudation and certain other processes were not quantified. The 4.2-fold decrease in measured ANPP was counterbalanced by a 4.2-fold increase in BNPP, which affirms the second hypothesis. The third main hypothesis also held true, as the results from the minirhizotron approach revealed an absolute 4.1-fold increase in annual fine root production, or a relative increase from 17.5 to $90.4 \%$ of total NPP. Only the fourth hypothesis could not be proved conclusively. It seems that this hypothesis explains very well the observed allocation shift from above- to belowground compartments. But as the photosynthetic carbon gain could not be determined within this study, it remains difficult to conclude definitely that a shift from light to nutrient limitation along the transect is the driving force of the allocation shift, or if only one of these factors causes the tremendous changes.

The total photosynthetic carbon gain should be mainly a function of solar irradiation, leaf photosynthetic capacity, photosynthetic photon flux densities and leaf area index (Malhi et al. 2004, Moser et al. 2007, Chapt.5). Photosynthetic capacity is mostly dependent on leaf lifespan, SLA, and leaf nitrogen concentration (e.g., Diemer 1998, Evans 1989, Field 1991, Field \& Mooney 1986, Gutschick \& Wiegel 1988, Kitajima et al. 1997, Reich 1993, Reich et al. 1992, 1994, 1999). With increasing elevation, leaf lifespan increased and SLA decreased, while area-related foliar N-contents increased slightly (M. Unger, unpubl.). Results concerning the photon flux density, measured in a single campaign (M. Unger, unpubl.), did not show an altitudinal trend in the South Ecuadorian transect. However, data from the RBSF area point to a significant reduction of incoming irradiance with increasing 
altitude due to increasing cloudiness (Bendix et al. 2008). Therefore, only LAI is definitely decreasing with elevation and so should total photosynthetic carbon gain.

Net primary production (NPP) is the balance of plant carbon gain and total plant respiration (leaf, stem and root respiration). There is evidence in the Ecuador transect, that the assumed altitudinal decrease in canopy carbon gain is at least partly counteracted by a substantial decrease in plant respiration along the transect. By measuring root respiration and stem respiration, respectively, Iost (2007) and Zach et al. (2008) produced evidence for a decline in respiratory carbon loss with elevation in this transect. Since it is too early to calculate total autotrophic respiration of the five stands, it must remain open whether the putative decrease in carbon gain is fully counteracted by a decrease in respiration. If both processes would decrease at a similar rate with elevation, NPP should indeed remain more or less constant with elevation.

Following the resource balance hypothesis (Bloom et al. 1985) the tremendous carbon allocation shift from above- to belowground components is best explained by a growing importance of limiting soil resources with increasing elevation. Increasing carbon and nutrient allocation to roots seems to represent a compensatory measure of the trees to cope with an increasing limitation by nutrient availability with elevation, and in the case of the coarse and large root system, with an increasing need for a stable anchorage due to high wind loads.

\subsection{RECOMMENDATION FOR FURTHER RESEARCH}

Additional transect studies on elevation transect should test the result of this study in a broader context. Gas exchange measurements along elevation gradients are urgently needed to obtain reliable results for photosynthetic carbon gain in tropical montane forests. Further research on nutrient limitation of montane forests along elevation gradients is also needed to understand which nutrient or nutrient species is mainly responsible for the observed aboveground growth limitation. The ongoing research at the Ecuadorian elevation gradient within the DFG Research Unit 816 (www.tropicalmountainforest.org), which includes a fertilization experiment, will hopefully clarify the latter question.

\subsection{ACKNOWLEDGEMENTS}

We thank S. Iost, TU Dresden, for data on soil and root respiration, A. Zach, University of Göttingen, for first results of wood respiration, M. Unger, University of Göttingen, for data on photosynthetically active radiation and leaf $\mathrm{N}$ content, and B. Schuldt, University of Göttingen, for data on xylem vessel size and conductivity of twigs and roots. We are grateful to the DFG for financial support.

\subsection{REFERENCES}

Aerts, R., Van der Peijl, M.J. 1993. A simple model to explain the dominance of lowproductive perennials in nutrient-poor habitats. Oikos 66: 144-147.

Bendix, J., Rollenbeck, R., Richter, M., Fabian, P., Emck, P. 2008. The altitudinal gradient - climate. In: Beck, E., Bendix, J., Kottke, I., Makeschin, F., Mosandl, R. (eds.). Gradients in a tropical mountain ecosystem of Ecuador. Springer Verlag, Berlin, Heidelberg, Ecological Studies 198, in press.

Bloom, A.J., Chapin III, F.S., Mooney, H.A. 1985. Ressource limitation in plants - an economic analogy. Annual Review of Ecology and Systematics 16: 363-392. 
Bruijnzeel, L.A., Veneklaas, E.J. 1998. Climatic conditions and tropical montane forest productivity: the fog has not lifted yet. Ecology 79: 3-9.

Chave, J., Andalo, C., Brown, S., Cairns, M.A., Chambers, J.Q., Eamus, D., Fölster, H., Fromard, F., Higuchi, N., Kira, T., Lescure, J.P., Nelson, B.W., Ogawa, H., Puig, H., Riera, B., Yamakura, T. 2005. Tree allometry and improved estimation of carbon stocks and balance in tropical forests. Oecologia 145: 87-99.

Clark, D.A. 2007. Detecting tropical forests' responses to global climatic and atmospheric change: current challenges and a way forward. Biotropica 39: 4-19.

Clark, D.A., Brown, S., Kicklighter, D.W., Chambers, J.Q., Thomlinson, J.R., Ni, J. 2001a. Measuring net primary production in forests: concepts and field methods. Ecological Applications 11: 356-370.

Clark, D.A., Brown, S., Kicklighter, D.W., Chambers, J.Q., Thomlinson, J.R., Ni, J., Holland, E.A. 2001b. Net primary production in tropical forests: an evaluation and synthesis of existing field data. Ecological Applications 11: 371-384.

Diemer, M. 1998. Leaf lifespans of high-elevation, aseasonal Andean shrub species in relation to leaf traits and leaf habit. Global Ecology and Biogeography Letters 7: 457465.

Evans, J.R. 1989. Photosynthesis and other nitrogen relationships in leaves of C3 plants. Oecologia 78: 9-19.

Field, C. 1991. Ecological scaling of carbon gain to stress and resource availability. In: Mooney, H.A., Winner, W.E., Pell, E.J. (eds.). Response of plants to multiple stresses. Academic Press, San Diego, California, USA, pp. 35-65.

Field, C., Mooney, H.A. 1986. The photosynthesis-nitrogen relationship in wild plants. In: Givnish, T.J. (ed.). On the economy of form and function. Cambridge University Press, Cambridge, England. pp. 25-55.

Flenley, J.R. 1995. Cloud forest, the Massenerhebung effect, and ultraviolet insolation. In: Hamilton, L.S., Juvrik, J.O., Scatena, F.N. (eds.). Tropical montane cloud forest, Springer Verlag, Berlin, New York. Ecological Studies 110: 150-155.

Gutschick, V.P., Wiegel, F.W. 1988. Optimizing the canopy photosynthetic rate by patterns of investment in specific leaf mass. American Naturalist 132: 67-86.

Hafkenscheid, R.L.L.J. 2000. Hydrology and biogeochemistry of tropical montane rain forests of contrasting stature in the Blue Mountains, Jamaica. Dissertation, Universiteit Amsterdam, pp. 302

Hertel, D., Leuschner, C. 2008. Fine root mass and fine root production in tropical moist forests as dependent on soil, climate and elevation. In: Bruijnzeel, L.E., Juvik, J.O. (eds.). Mountains in the mist: Science for conserving and managing tropical montane cloud forests. Hawaii University Press. in press.

Hue, N.V., Craddock, G.R., Adams, F. 1986. Effect of organic-acids on aluminum toxicity in subsoils. Soil Science Society of America Journal 50: 28-34.

Iost, S. 2007. Soil respiration, microbial respiration and mineralisation in soils of montane rainforests of Southern Ecuador: influence of altitude. Dissertation, TU Dresden, pp.171.

Kitajima, K., Mulkey, S.S., Wright, S.J. 1997. Decline of photosynthetic capacity with leaf age in relation to leaf longevities for five tropical canopy tree species. American Journal of Botany 85: 702-708.

Kitayama, K., Aiba, S.-I. 2002. Ecosystem structure and productivity of tropical rain forests along altitudinal gradients with contrasting soil phosphorus pools on Mount Kinabalu, Borneo. Journal of Ecology 90: 37-51.

Küppers, M., Motzer, T., Schmitt, D., Ohlemacher, C., Zimmermann, R., Horna, V., Küppers, B.I.L., Mette, T. 2008. Stand structure, transpiration responses in trees and vines and stand transpiration of different forest types within the mountain rainforests. 
In: Beck, E., Bendix, J., Kottke, I., Makeschin, F., Mosandl, R. (eds.). Gradients in a tropical mountain ecosystem of Ecuador. Springer Verlag, Berlin, Heidelberg. Ecological Studies 198, in press.

Malhi, Y., Baker, T.R., Phillips, O.L., Almeidas, S., Alvarez, E., Arroyo, L., Chave, J., Czimczik, C.I., Di Fiore, A., Higuchi, N., Killeen, T.J., Laurance, S.G., Laurance, W.F., Lewis, S.L., Mercado Montoya, L.M., Monteagudo, A., Neill, D.A., Núnez Vargas, P., Patiños, S., Pitman, N.C.A., Quesada, C.A., Salomão, R., Macedo Silva, J.N., Torres Lezama, A., Vásquez Martínez, R., Terborgh, J., Vinceti, B., Lloyd, J. 2004. The above-ground coarse wood productivity of 104 Neotropical forest plots. Global Change Biology 10: 563-591.

Maraun, M., Illig, J., Sandman, D., Krashevskaya, V., Norton, R.A., Scheu, S. 2008. Soil fauna. In: Beck, E., Bendix, J., Kottke, I., Makeschin, F., Mosandl, R. (eds.). Gradients in a tropical mountain ecosystem of Ecuador. Springer Verlag, Berlin, Heidelberg. Ecological Studies 198, in press.

Moser, G., Hertel, D. \& Leuschner, Ch. 2007. Altitudinal change in LAI and stand leaf biomass in tropical montane forests - a transect study in Ecuador and a pan-tropical meta-analysis. Ecosystems 10: 924-935.

Northup, R.R., Dahlgren, R.A., YU, Z. S. 1995. Intraspecific variation of conifer phenolic concentration on a marine terrace soil acidity gradient - a new interpretation. Plant and Soil 171: 255-262.

Odum, H.T. 1970. Rain forest structure and mineral-cycling homeostasis. In: Odum, H.T.,

Raich, J.W., Russel, A.E., Vitousek, P.M. 1997. Primary productivity and ecosystem development along an elevational gradient on Mauna Loa, Hawai'i. Ecology 78: 707721.

Reich, P.B., Walters, M.B., Ellsworth, D.S. 1992. Leaf lifespan in relation to leaf, plant and stand characteristics among diverse ecosystems. Ecological Monographes 62: 365-392.

Reich, P.B. 1993. Reconciling Apparent Discrepancies Among Studies Relating Life-Span, Structure and Function of Leaves in Contrasting Plant Life Forms and Climates - the Blind Men and the Elephant Retold. Functional Ecology 7: 721-725.

Reich, P.B., Walters, M.B., Ellsworth, D.S., Uhl, C. 1994. Photosynthesis-nitrogen relations in Amazonian tree species .1. Patterns among species and communities. Oecologia 97: 62-72.

Reich, P.B., Ellsworth, D.S., Walters, M.B., Vose, J.M., Gresham, C., Volin, J.C., Bowman, W.D. 1999. Generality of leaf trait relationships: a test across six biomes. Ecology 80: 1955-1969.

Richter, M., Diertl, K.-H., Peters, T., Bussmann, R. 2008. Vegetation structures and ecological features of the upper timberline ecotone. In: Beck, E., Bendix, J., Kottke, I., Makeschin, F., Mosandl, R. (eds.). Gradients in a tropical mountain ecosystem of Ecuador. Springer Verlag, Berlin, Heidelberg. Ecological Studies 198, in press.

Soethe, N., Lehmann, J., Engels, C. 2006a. Root morphology and anchorage of six native tree species from a tropical montane forest and an elfin forest in Ecuador. Plant and Soil 279: 173-185.

Soethe, N., Lehmann, J., Engels, C. 2006b. The vertical pattern of rooting and nutrient uptake at different altitudes of a south Ecuadorian montane forest. Plant and Soil 286: 287-299.

Vitousek, P.M., Turner, D.R., Parton, W.J., Sanford Jr., R.L. 1994. Litter decomposition on the Mauna Loa environmental matrix, Hawaii: patterns, mechanisms, and models. Ecology 75: 418-429.

Wang, D., Bormann, F.H., Lugo, A.E., Bowden, R.D. 1991. Comparison of nutrient-use efficiency and biomass production in 5 tropical tree taxa. Forest Ecology and Management 46: 1-21. 
Weaver, P.L., Murphy, P.G. 1990. Forest structure and productivity in Puerto-Rico Luquillo Mountains. Biotropica 22: 69-82.

Zach, A., Horna, V. Leuschner Ch. 2008. Elevational change in woody-tissue $\mathrm{CO}_{2}$ efflux in a tropical mountain rain forest in southern Ecuador. Tree Physiology 28: 67-74. 

A P P EN D I X 

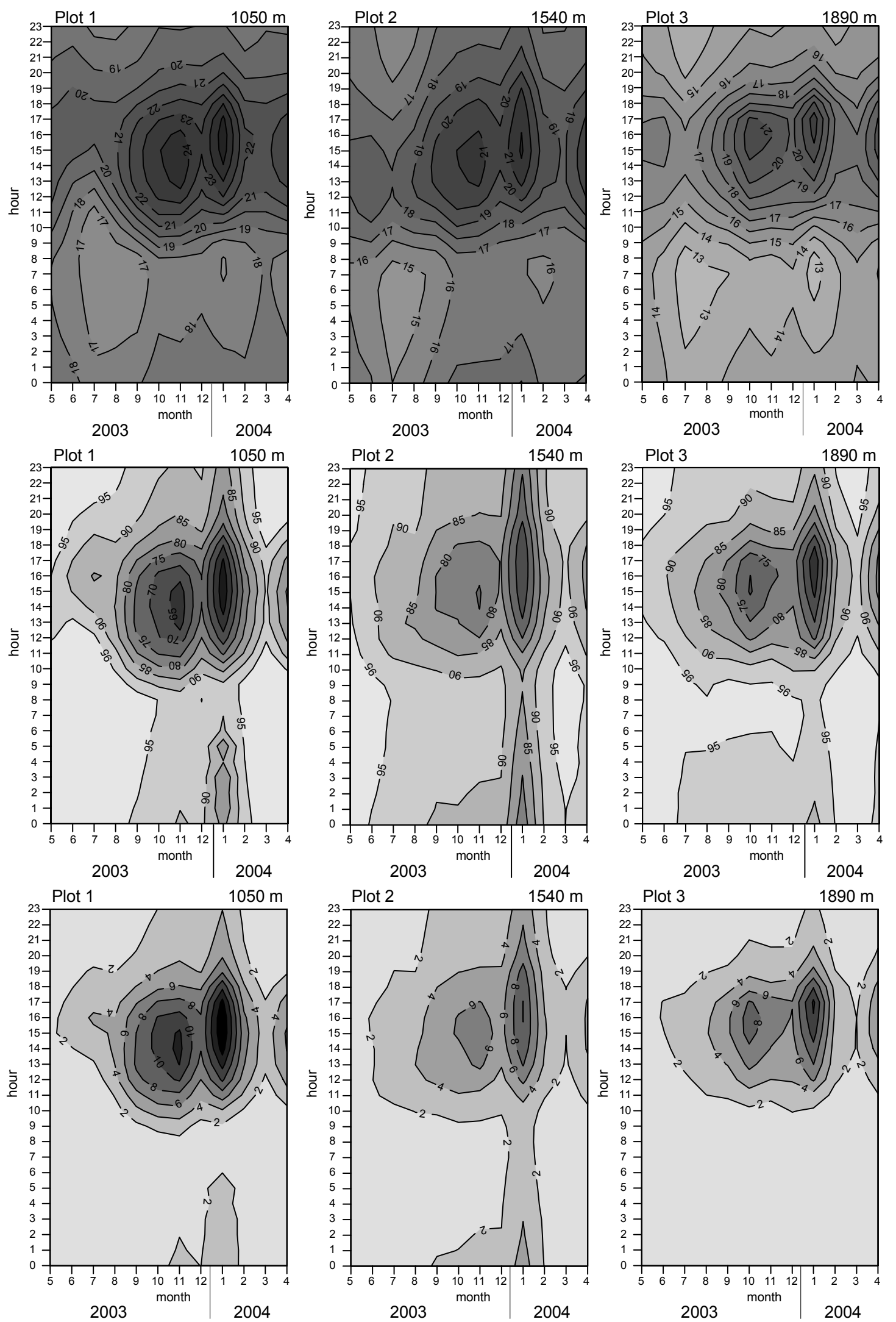

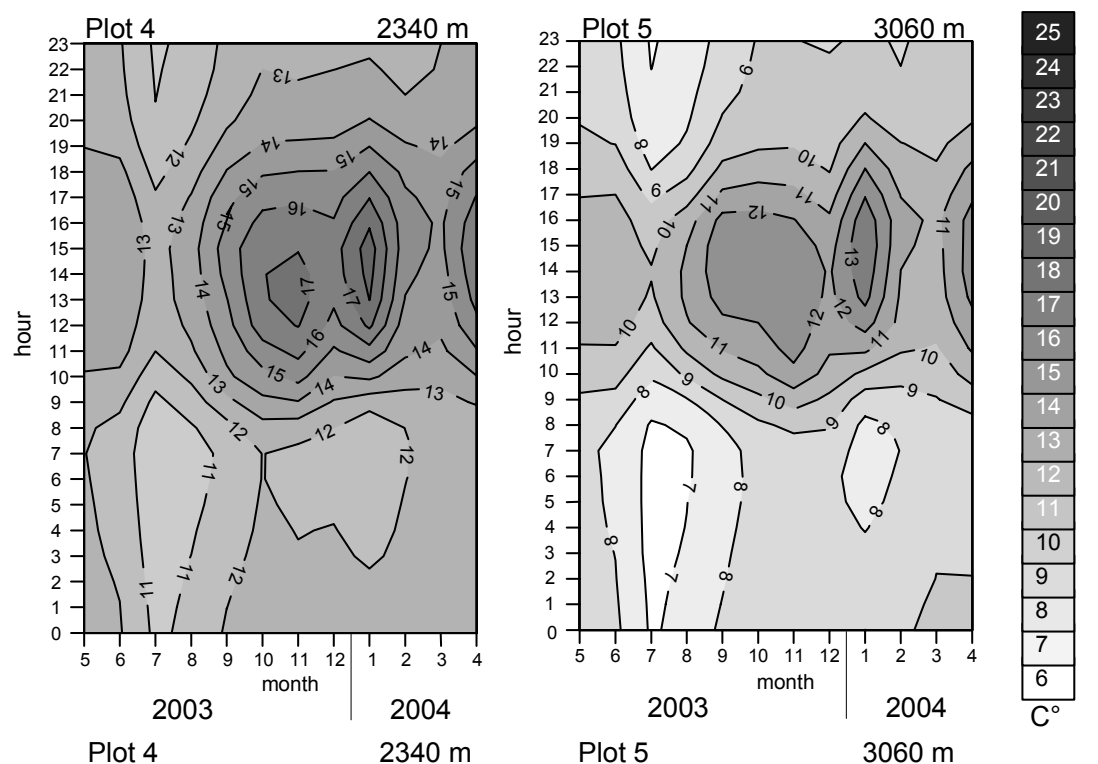

Figure 8.1: Hourly means of air temperature measured inside the forest stands at $1.5 \mathrm{~m}$ above ground during the one-year period of biomass production measurements starting in May 2003.
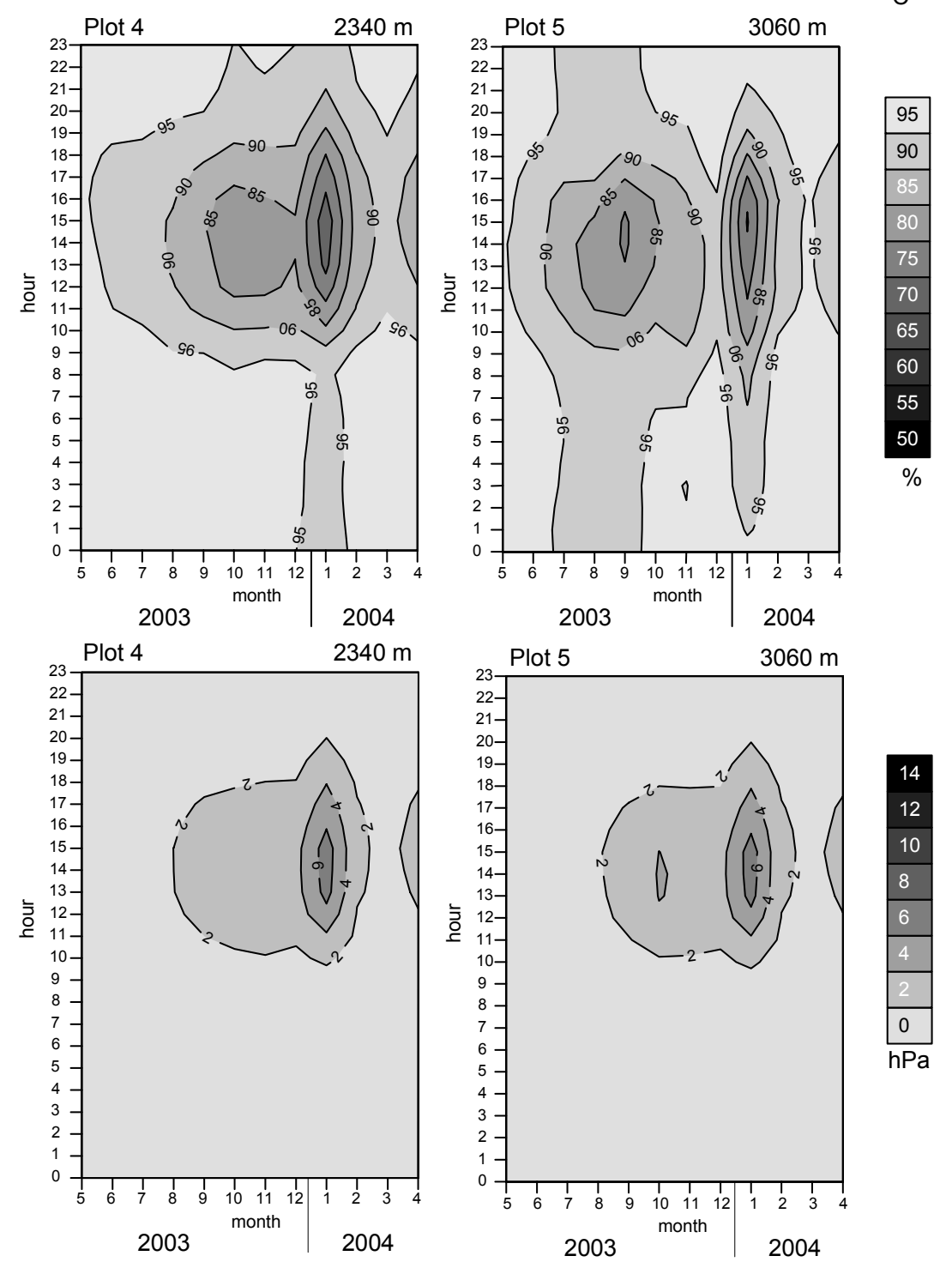

Figure 8.2: Hourly means of relative air humidity measured inside the forest stands at $1.5 \mathrm{~m}$ above ground during the one- year period of biomass production measurements, from May 2003 to April 2004.

Figure 8.3: Hourly means of vapour pressure deficit calculated from air temperature and relative humidity data (1.5 $\mathrm{m}$ above ground) during the one-year period of biomass production measurements, from May 2003 to April 2004. 

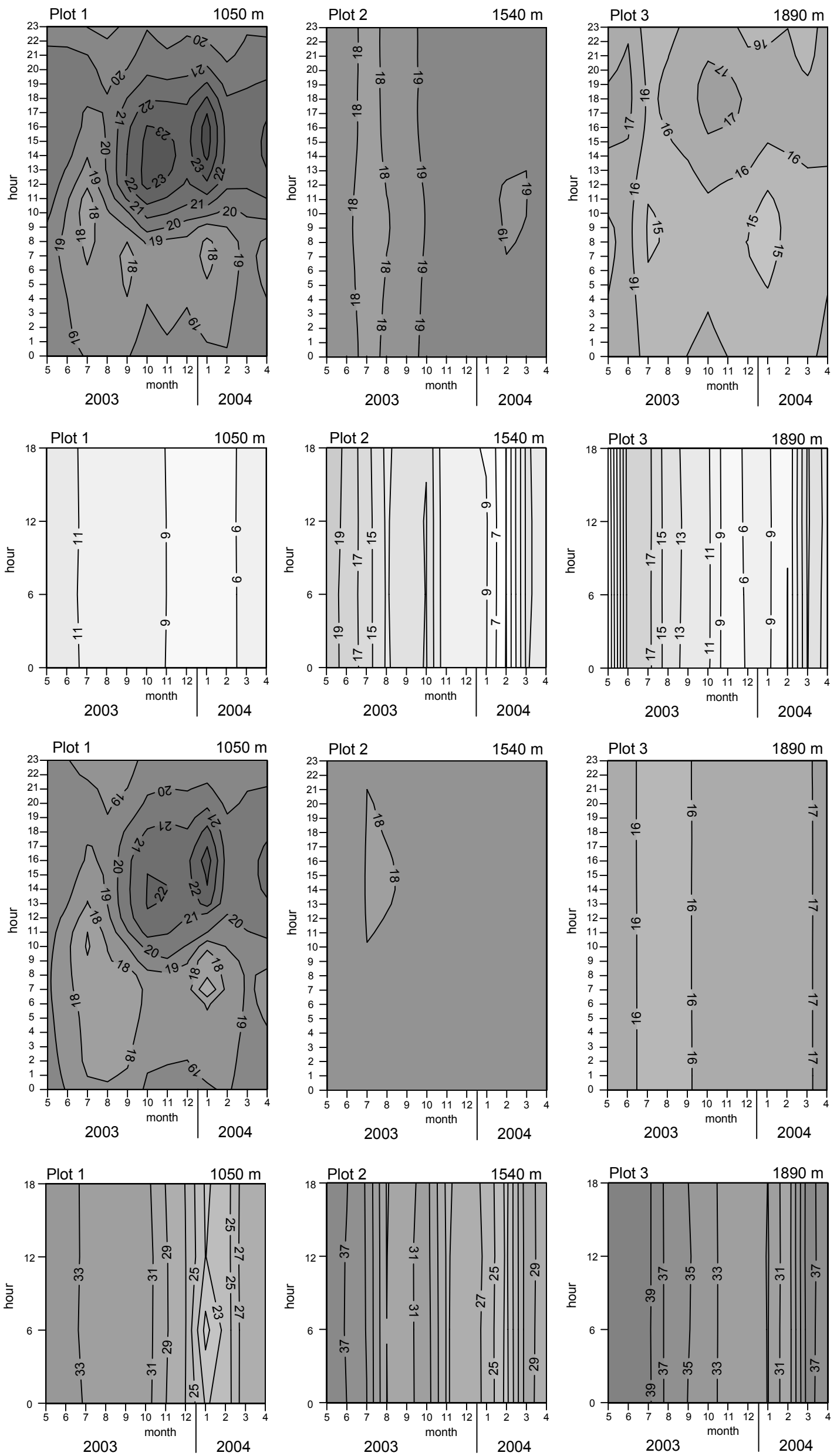

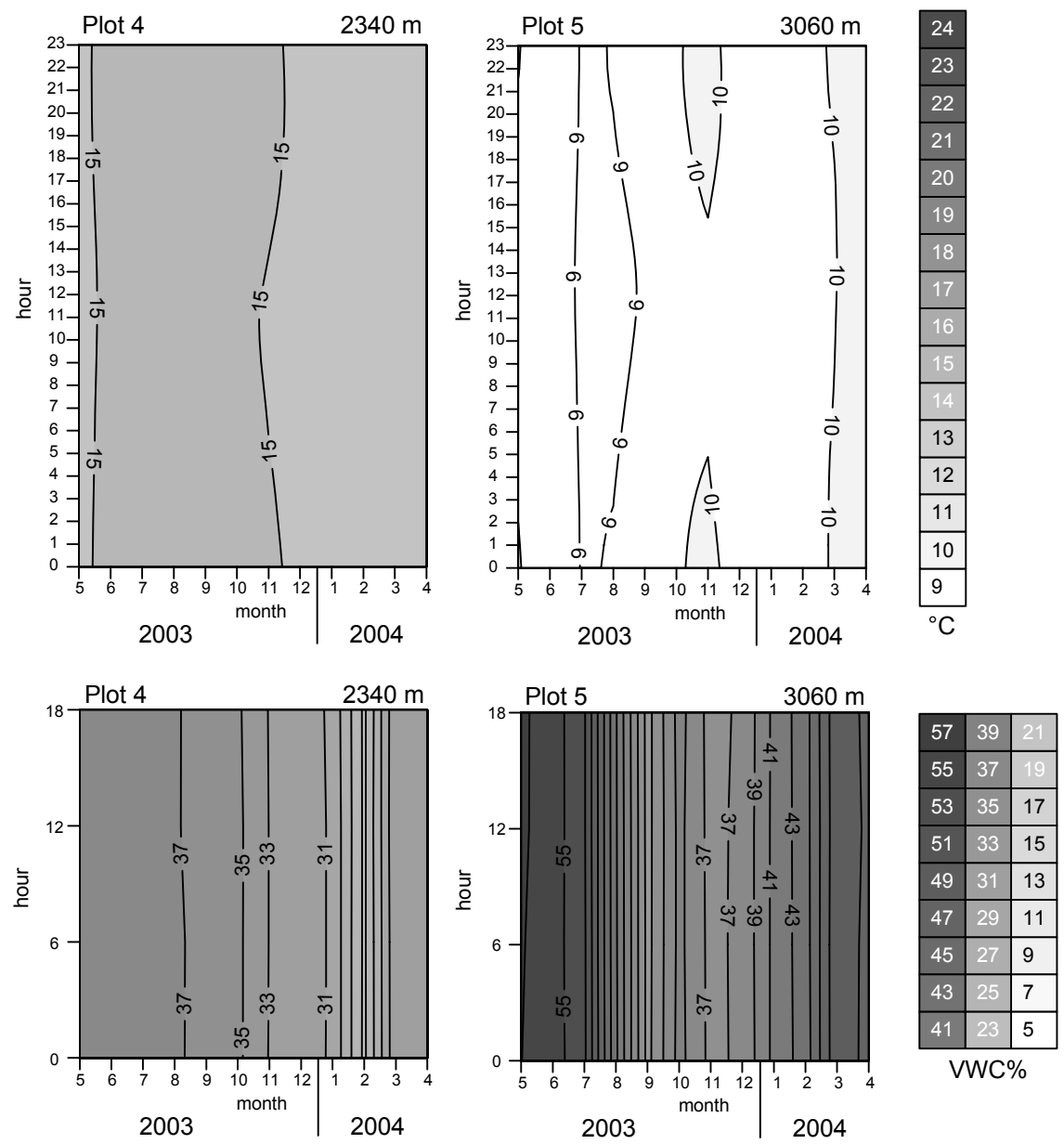

Figure 8.4: Hourly means of organic layer temperature measured in the middle of the organic layer during the one-year period of biomass production measurements, starting in May 2003.
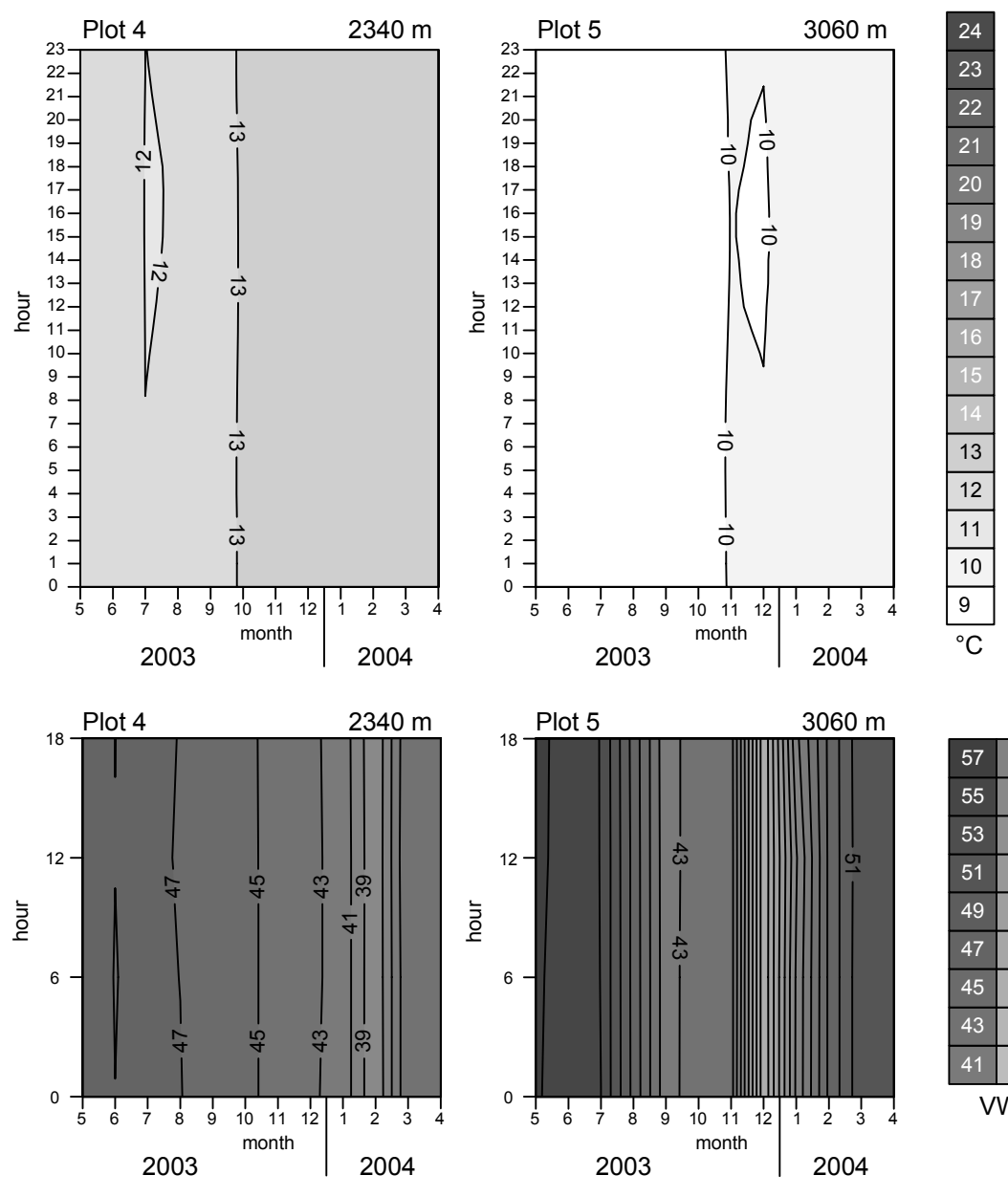

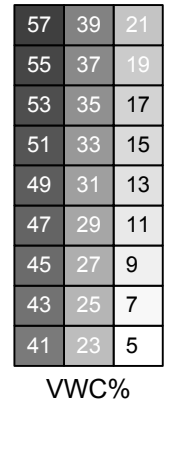

Figure 8.5: Hourly means of volumetric soil water content measured in the middle of the organic layer during the one-year period of biomass production measurements, starting in May 2003.

Figure 8.6: Hourly means of soil temperature measured in 10 $\mathrm{cm}$ depth of the mineral soil during the one-year period of biomass production measurements, starting in May 2003.

Figure 8.7: Hourly means of volumetric soil water content measured in $10 \mathrm{~cm}$ depth of the mineral soil during the one-year measuring period of biomass production, starting in May 2003. 


\section{List I}

Reference list for the sources of 184 surveyed allometric equations for moist tropical forests:

Aiba, S., Kitayama, K. 1999. Structure, composition and species diversity in an altitudesubstrate matrix of rain forest tree communities on Mount Kinabalu, Borneo. Plant Ecology 140: 139-157.

Aplet, G.H., Vitousek, P.M. 1994. An age altitude matrix analysis of Hawaiian rain-forest succession. Journal of Ecology 82: 137-147.

Araujo, T.M., Higuchi, N., de Carvalho Jr, J.A. 1999. Comparison of formulae for biomass content determination in a tropical rain forest site in the state of Para, Brazil. Forest Ecology and Management 117: 43-52.

Baker, T.R., Phillips, O.L., Mahli, Y., Almeidas, S., Arroyo, L., Di Fiore, A., Erwin, T., Higuchi, N., Killeen, T.J., Laurance, S.G., Laurance, W.F., Lewis, S.L., Monteagudo, A., Neill, D.A., Vargas Núñez, P., Pitman, N.C.A., Silva, J.N.M., Martínez Vásquez, R. 2004. Increasing biomass in Amazonian forest plots. Philosophical Transaction of the Royal Society London, Ser B 359: 353-365.

Brown, I.F., Martinelli, L.A., Thomas, W.W., Moreira, M.Z., Ferreira, C.A.C., Victoria, R.A. 1995. Uncertainty in the biomass of Amazonian forests - an example from Rondonia, Brazil. Forest Ecology and Management 75:175-189.

Brown, S., Gillespie, A.J.R., Lugo, A.E. 1989. Biomass estimation methods for tropical forests with applications to forest inventory data. Forest Science 35: 881-902.

Brown, S., Iverson, L.R. 1992. Biomass estimates for tropical forests. World Resource Review 4: 366-384.

Brun, R. 1976. Methodik und Ergebnisse zur Biomassenbestimmung eines NebelwaldÖkosystems in den venezolanischen Anden. Proc. 16th IUFRO World Congress, Div. I, Oslo, Norway: 490-499.

Cannell, M.G.R 1984. Woody biomass of forest stands. Forest Ecology and Management 8: 299-312.

Chave, J., Andalo, C., Brown, S., Cairns, M.A., Chambers, J.Q., Eamus, D., Fölster, D., Fromard, F., Higuchi, N., Kira, T., Lescure, J.-P., Nelson, B.W., Ogawa, H., Puig, H., Riéra, B., Yamakura, T. 2005. Tree allometry and improved estimation of carbon stocks and balance in tropical forests. Oecologia 145: 87-99.

Chave, J., Condit, R., Aguilar, S., Hernandez, A., Lao, S., Perez, R. 2004. Error propagation and scaling for tropical forest biomass estimates. Philosophical Transaction of the Royal Society London, Ser B 359: 409-420.

Chave, J., Condit, R., Lao, S., Caspersen, J.P., Foster, R.B., Hubbell, S.P. 2003. Spatial and temporal variation of biomass in a tropical forest: results from a large census plot in Panama. Journal of Ecology 91: 240-252.

Cole, T.G., Ewel, J.J. 2006. Allometric equations for four valuable tropical tree species. Forest Ecology and Management 229: 351-360.

Cummings, D.L., Kauffman, J.B., Perry, D.A., Hughes, R.F. 2002. Aboveground biomass and structure of rainforests in the southwestern Brazilian Amazon. Forest Ecology and Management 163: 293-307.

de Castilho, C.V., Magnusson, W.E., de Araújo,R.N.O., Luizão,R.C.C., Luizão, F.J., Lima, A.P., Higuchi, N. 2006. Forest Ecology and Management 234: 85-96.

Fölster, H., De las Salas, G., Khanna, P. 1976. A tropical evergreen forest site with perched water table, Magdalen valley, Columbia - biomass and bioelement inventory of primary and secondary vegetation. Oecologia Plantarum 11 (4): 297-320.

Frangi, J.L., Lugo, A.E. 2005. Ecosystems dynamics of a sub-tropical floodplain. Ecological Monographs 55: 351-369. 
Halenda, C.J. 1989. The Ecology of fallow forest after shifting cultivation in Niah Forest Reserve. Report Forest Department, Sarawak, Malaysia. Forest Ecology. cited in Jepsen, M.R. 2006. Above-ground carbon stocks in tropical fallows, Sarawak, Malaysia. Forest Ecology and Management 225: 287-295.

Hashimotio, T., Kojima, K., Tange, T., Sasaki, S., 2000. Change in carbon storage in fallow forests in the tropical lowlands of Borneo. Forest Ecology and Management 126: 331337.

Higuchi, N., Dos Santos, J., Ribeiro, R.J., Minette, L., Biot, Y. 1998. Biomassa da Parte Aerea da Vegetacao da Floresta tropical Umida de Terra-firme da Amazonia Brasileira. Acta Amazonica 28: 153-165.

Hughes, R.F., Kauffman, J.B., Jaramillo, V.J. 1999. Biomass, carbon, and nutrient dynamics of secondary forests in a humid tropical region of Mexico. Ecology 80: 1892-1907.

Keller, M., Alencar, A., Asner, G.P., Braswell, B., Bustamante, M., Davidson, E., Feldpausch, T., Fernandes, E., Goulden, M., Kabat, P., Kruijt, B., Luizao, F., Miller, S., Markewitz, D., Nobre, A.D., Nobre, C.A., Priante, N., Da Rocha, H., Dias, P.S., Von Randow, C., Vourlitis, G.L. 2004. Ecological research in the large-scale biosphere-atmosphere experiment in Amazonia: early results. Ecological Applications 14: S3-S16.

Ketterings, Q.M., Coe, R., Van Noordwijk, M., Amabagau, Y., Palm, C.A. 2001. Reducing uncertainty in the use of allometric biomass equations for predicting above-ground tree biomass in mixed secondary forests. Forest Ecology and Management 146: 199-209.

Liddell, M.J, Nieullet, N., Campoe, O.C., Freiberg, M. 2007. Assessing the above-ground biomass of a complex tropical rainforest using a canopy crane. Austral Ecology 32: 4358.

Magcale-Macandog, D.B., Delgado, M.E.M., Ty, E., Villarin, J.R.T. 2006. A GIS based model to improve estimation of aboveground biomass of secondary forests in the Philipppines. Journal of Tropical Forest Science 18: 8-21.

Nascimiento, H.E.M., Laurance, W.F. 2002. Total aboveground biomass in central Amazonian rainforests: a landscape-scale study. Forest Ecology and Management 168: 311-321.

Nelson, B.W., Mesquita, R., Pereira, J.L.G., De Souza, S.G.A., Batista, G.T., Couto, L.B. 1999. Allometric regressions for improved estimate of secondary forest biomass in the central Amazon. Forest Ecology and Management 117: 149-167.

Ogawa, H., Yoda, K., Ogino, K., Kira, T. 1965. Comparative ecological studies on three main types of forest vegetation in Thailand. II. Plant biomass. Nature Life Southeast Asia 4: 49-80.

Overman, J.P.M., Witte, J.H.L., Aldarriaga, J.G. 1994. Evaluation of regression-models for aboveground biomass determination of Amazon rain-forest. Journal of Tropical Ecology 10: 207-218.

Raich, J.W., Russell, A.E., Vitousek, P.M. 1997. Primary productivity and ecosystem development along an elevational gradient on Mauna Loa, Hawai'i. Ecology 78: 707721.

Saldarriaga, J.G., West, D.C., Tharp, M.L., Uhl, C. 1988. Long-term chronosequence of forest succession in the upper Rio Negro of Colombia and Venezuela. Journal of Ecology 76: 938-958.

Segura, M. \& Kanninen, M. (2005) Allometric models for tree volume and total aboveground biomass in a tropical humid forest in Costa Rica. Biotropica 37: 2-8.

Sierra, C.A., del Valle, J.I., Orrego, S.A., Moreno, F.H., Harmon, M.E., Zapata, M., Colorado, G.J., Herrera, M.A., Lara, W., Restrepo, D.E., Berrouet, L.M., Loaiza, L.M., 
Benjumea, J.F. 2007. Total carbon stocks in a tropical forest landscape of the Porce region, Colombia. Forest Ecology and Management 243: 299-309.

Scatena, F.N., Silver, W.L., Siccama, T., Johnson, A., Sanchez, M.J. 1993. Biomass and nutrient content of the Cisley Experimental Watershed, Luquillo Exoerimental Forest, Puerto Rico, before and after hurricane Hugo, 1989. Biotropica 25: 15-27.

Segura, M., Kanninen, M. 2005. Allometric models for tree volume and total aboveground biomass in a tropical humid forest in Costa Rica. Biotropica 37: 2-8.

Tanner, E.V.J 1980. Studies on the biomass and productivity in a series of montane rain forests in Jamaica. Journal of Ecology 68: 573-588.

Uhl, C., Clark, K., Dezzeo, N., Maquirino, P. 1988. Vegetation dynamics in Amazonian treefall gaps. Ecology 69: 751-763.

Yamakura, T., Hagihara, A., Sukardjo, S., Ogawa, H. 1986. Aboveground biomass of tropical rain-forest stands in Indonesian Borneo. Vegetatio 68: 71-82. 


\section{List II}

Reference list for sources of 267 moist neotropical forest stands relating to forest structure and above- and belowground biomass:

Baker, T.R., Phillips, O.L., Malhi, Y., Almeida, S., Arroyo, L., Di Fiore, A., Erwin, T., Killeen, T.J., Laurance, S.G., Laurance, W.F., Lewis, S.L., Lloyd, J., Monteagudo, A., Neill, D.A., Patino, S., Pitman, N.C.A., Silva, J.N.M., Martínez, R.V. 2004. Variation in wood density determines spatial patterns in Amazonian forest biomass. Global Change Biology 10: 545-562.

Baker, T.R., Phillips, O.L., Malhi, Y., Almeidas, S., Arroyo, L., Di Fiore, A., Erwin, T., Higuchi, N., Killeen, T.J., Laurance, S.G., Laurance, W.F., Lewis, S.L., Monteagudo, A., Neill, D.A., Vargas Núñez, P., Pitman, N.C.A., Silva, J.N.M., Martínez Vásquez, R. 2004. Increasing biomass in Amazonian forest plots. Philosophical Transaction of the Royal Society London, Ser B 359: 353-365.

Balslev, H., Luteyn, J.L., Øllgaard, B., Holm-Nielsen, L.B. 1987. Composition and structure of adjacent unflooded and floodplain forest in Amazonian Ecuador. Opera Botanica 92: 37-57.

Black, G.A., Dobzhansky, T., Pavan, C. 1950. Some attempts to estimate species diversity and population density of trees in Amazonian forests. Botanical Gazette 111: 413-425.

Boom, B.M. 1986. A forest inventory in Amazonian Bolivia. Biotropica 18: 287-294.

Brun, R. 1976. Methodik und Ergebnisse zur Biomassenbestimmung eines NebelwaldÖkosystems in den venezolanischen Anden. Proc. 16th IUFRO World Congress, Div. I, Oslo, Norway: 490-499.

Cain, S.A., De Olivera Castro, G.M., Pires, J.M., Da Silva, N.T. 1956. Application of some phytosociological techniques to Brazilian rain forest. American Journal of Botany 43: 911-941.

Campbell, D.G., Daly, D.C., Prance, G.T., Maciel, U.N. 1986. Quantitative ecological inventory of terra-firme and varzea tropical forest on the Rio-Xingu, Brazilian Amazon. Brittonia 38: 369-393.

Chave, J., Condit, R., Lao, S., Caspersen, J.P., Foster, R.B., Hubbell, S.P. 2003. Spatial and temporal variation of biomass in a tropical forest: results from a large census plot in Panama. Journal of Ecology 91: 240-252.

Clark, D.A., Brown, S., Kicklighter, D.W., Chambers, J.Q., Thomlinson, J.R., Ni, J., Holland, E.A. 2001. Net primary production in tropical forests: an evaluation and synthesis of existing field data. Ecological Applications 11: 371-384.

Cuello, N.L. 2002. Altitudinal changes of forest diversity and composition in the Ramal de Guaramacal in the Venezuelan Andes. Ecotropicos 15: 160-176.

Cummings, D.L., Kauffman, J.B., Perry, D.A., Hughes, R.F. 2002. Aboveground biomass and structure of rainforests in the southwestern Brazilian Amazon. Forest Ecology and Management 163: 293-307.

Dantas, M., Muller, N.R.M. 1979. Estudos fito-ecológicos do tropico úmido brasileiro aspectos fitosociológicos de mata sobre terra roxa na regiao de Altamira. Anales de la Sociedad Botanica Brasil 30: 205-218.

Dantas, M., Rodrigues, I.M.A., Muller, N.R.M. 1980. Estudos fito-ecológicos do tropico úmido brasileiro: aspectos fitosociológicos de mata sobre latisolo amarelo em Capitao Poco. Bol. Pesq. 9.

De Graaf, N.R., Poils, R.L.H., Van Rompaey, R.S.A.R. 1999. Effect of silvicultural treatment on growth and mortality of rainforest in Surinam over long periods. Forest Ecology and Management 124: 123-135. 
Dewalt, S.J., Schnitzler, S.A., Denslow, J.A. 2000. Density and diversity of lianas along a chronosequence in central Panamanian lowland forest. Journal of Tropical Ecology 16: $1-19$.

Fölster, H., De las Salas, G., Khanna, P. 1976. A tropical evergreen forest site with perched water table, Magdalen valley, Columbia - biomass and bioelement inventory of primary and secondary vegetation. Oecologia Plantarum 11: 297-320.

Gentry, A.H., Lötscher, H., Oeschger, H., Seigenthaler, U., Stuffer, B. 1995. Patterns of diversity and floristic composition in neotropical montane forests. In: Churchill, S.P. (ed). Biodiversity and conservation of neotropical montane forests. New York Botanical Garden, The Bronx, USA pp. 103-126.

Grimm, U., Fassbender, H.W. 1981. Ciclos bioquímicos en un ecosistema forestal de los Andes Occidentales de Venezuela. I. Inventario de las reservas orgánicas y minerales (N, P, K, Ca, Mg, Mn, Fe, Al, Na). Turrialba 31: 27-37.

Grubb, P.J., Lloyd, J.R., Pennington, T.D., Whitmore, T.C. 1963. A comparison of montane and lowland rain-forest in Ecuador. 1. The forest structure, physiognomy, and floristics. Journal of Ecology 51: 567-601.

Grubb, P.J., Tanner, E.V.J. 1976. The montane forests and soils in Jamaica: a reassessment. Journal of the Arnold Arboretum 57: 313-368.

Golley, F.B., McGinnis, J.T., Clement, R.G., Child, G.I., Duever, M.J. 1975. Mineral cycling in a tropical moist forest ecosystem. University of Georgia Press, Athens, USA, pp. 258.

Guilherme, F.A.G., Morellato, L.P.C., Assis, M.A. 2004. Horizontal and vertical tree community structure in a lowland Atlantic rain forest, Southeastern Brazil. Revista Brasileira de Botanica 27: 725-737.

Hartshorn, G.S. 1980. Forest vegetation (of Manu Park, Peru). Tropical Science Center, San Jose, Costa Rica.

Hetsch, W., Hoheisl, H. 1976. Standorts- und Vegetationsgliederung in einem tropischen Nebelwald. Allgemeine Forst- und Jagdzeitung 147: 200-209.

Homeier, J. 2004. Baumdiversität, Waldstruktur und Wachstumsdynamik zweier tropischer Bergregenwälder in Ecuador und Costa Rica. Dissertationes Botanicae 391, pp. 207.

Hughes, R.F., Kauffman, J.B., Cummings, D.L. 2002. Dynamics of aboveground and soil carbon and nitrogen stocks and cycling of available nitrogen along a land-use gradient in Rondonia, Brazil. Ecosystems 5: 244-259.

Jordan, C.F. 1982. The nutrient balance of an Amazonian rain forest. Ecology 63: 647-654.

Jordan, C.F., Escalante, G. 1980. Root productivity in an Amazonian rain forest. Ecology 61(1): 14-18.

Jørgensen, P.M., Ulloa, C.U., Madsen, J.E., Valencia, R. 1995. A floristic analysis of the high Andes of Ecuador. In: Churchill, S.P., Balslev, H., Forero, E., Luteyn, J.L. (eds.). Biodiversity and conservation of neotropical montane forests. New York Botanical Garden, New York, pp. 221-237.

Klinge, H. 1976. Bilanzierung von Hauptnährstoffen im Ökosystem tropischern Regenwald (Manaus) - vorläufige Daten. Biogeographica 7: 59-77.

Köhler, L. 2002. Die Bedeutung der Epiphyten im ökosystemaren Wasser- und Nährstoffumsatz verschiedener Altersstadien eines Bergregenwaldes in Costa Rica. Berichte des Forschungszentrums Waldökosysteme, Reihe A, Bd. 181, pp. 134.

Korning, J., Balslev, H. 1994. Growth-rates and mortality patterns of tropical lowland tree species and the relating to forest structure in Amazonian Ecuador. Journal of Tropical Ecology 10: 151-166.

Korning, J., Thomsen, K., Øllgaard, B. 1991. Composition and structure of a species rich Amazonian rain-forest obtained by 2 different sample methods. Nordic Journal of Botany 11: 103-110. 
Lechthaler, R. 1956. Inventário das árvores de um hectare de terra firme na zona Reserva Florestal Ducke, Município de Manaus. Botânica 3. Rio de Janeiro.

Lewis, S.L., Phillips, O.L., Baker, T.R., Lloyd, J., Malhi, Y., Almeida, S., Higuchi, N., Laurance, W.F., Neill, D.A., Silva, J.N.M., Terborgh, J., Lezama, A.T., Martínez Vásquez, R., Brown, S., Chave, J., Kuebler, C. Vargas Núñez, P., Vinceti, B. 2004. Concerted changes in tropical forest structure and dynamics: evidence from 50 South American long-term plots. Philosophical Transaction of the Royal Society London, Ser B 359: 421-436.

Madsen, J.E., Øllgaard, B. 1994. Floristic composition, structure, and dynamics of an upper montane rain-forest in Southern Ecuador. Nordic Journal of Botany 14: 403-423.

Malhi, Y., Baker, T.R., Phillips, O.L., Almeidas, S., Alvarez, E., Arroyo, L., Chave, J., Czimczik, C.I,. Di Fiore, A. Higuchi, N., Killeen, T.J., Laurance, S.G., Laurance, W.F., Lewis, S.L., Mercado Montoya, L.M., Monteagudo, A., Neill, D.A., Núñez Vargas, P., Patiño, S., Pitman, N.C.A., Quesada, C.A., Salomão, R., Macedo Silva, J.N., Torres Lezama, A., Vásquez Martínez, R., Terborgh, J., Vinceti, B., Lloyd, J. 2004. The above-ground coarse wood productivity of 104 neotropical forest plots. Global Change Biology 10: 563-591.

McWilliam, A.L.C., Roberts, J.M., Cabral, O.M.R., Leitao, M.V.B.R., Decosta, A.C.L., Maitelli, G.T., Zamparoni, C.A.G.P. 1993. Leaf-area index and aboveground biomass of terra-firme rain-forest and adjacent clearings in Amazonia. Functional Ecology 7: 310-317.

Nascimento, H.E.M., Laurance, W.F. 2002. Total aboveground biomass in central Amazonian rainforests: a landscape-scale study. Forest Ecology and Management 168: 311-321.

Nebel, G., Kvist, L.P., Vanclay, J.K., Christensen, H., Freitas, L., Ruiz, J. 2001. Structure and floristic composition of flood plain forests in the Peruvian Amazon I. Overstorey. Forest Ecology and Management 150: 27-57.

Nebel, G., Dragsted, J., Vega, A.S. 2001. Litter fall, biomass and net primary production in flood plain forests in the Peruvian Amazon. Forest Ecology and Management 150: 93102.

Odum, H.T. 1970. Summary - an emerging view of the ecological system at El Verde. In: Odum, H.T., Pigeon, R.F. (eds.). A tropical rain forest. U.S. Atomic Energy Commission, Washington D.C. pp. 191-289.

Ovington, J.D., Olson, J.S. 1970. Biomass and chemical content of El Verde lower montane rain forest plants. In: Odum, H.T., Pigeon, R.F. (eds.) A tropical rain forest. U.S. Atomic Energy Commission, Washington D.C., pp. 53-77.

Phillips, D.L., and more than 50 others (et al.) 2004. Pattern and process in Amazon tree turnover, 1976-2001. Philosophical Transaction of the Royal Society London, Ser B 359: 381-407.

Pires, J.M., Dobzhansky, T., Black, G.A. 1953. An estimate of the number of species of trees in an Amazonian forest community. Botanical Gazette 114: 467-477.

Pires, J.M., Koury, H.M. 1958. Estudo de um trecho de mata de várzea próximo de Belém. Boletim Técnico I.A.N. 36: 3-44.

Pires, J.M. 1966. The estuaries of the Amazon and Oyapoque Rivers. UNESCO. Proc. of the Decca Symposium. pp. 211-218.

Prance, G.T., Rodrigues, W.A., Da Silva, M.F. 1976. Inventário florestal de um hectare de mata de terra firme km 30 da estrada Manaus-Itacoatiara. Acta Amazonica 6: 9-35.

Prance, G.T., Elias, T.S. 1977. Extinction is forever. Columbia University Press, New York.

Rice, A.H., Pyle, E.H., Saleska, S.R., Hutyra, L., Palace, M., Keller, M., De Camargo, P.B., Portilho, K., Marques, D.F., Wofsy, S.C. 2004. Carbon balance and vegetation dynamics in an old-growth Amazonian forest. Ecological Applications 14: S55-S71. 
Rodrigues, W.A. 1963. Estudo de 2,6 hectares de mata de terra firme da Serra do Navio, Territorio do Amapá. Bol. Mus. Paraense Hist Nat Nov Sér Bot 19. Belém.

Saldarriaga, J.G., West, D.C., Tharp, M.L., Uhl, C. 1988. Long-term chronosequence of forest succession in the upper Rio Negro of Colombia and Venezuela. Journal of Ecology 76: 938-958.

Smith, D.N., Killeen, T.J. 1998. A comparison of the structure and composition of montane and lowland tropical forest in the Serranía pilón Lajas, Beni, Bolivia. In: Dallmeier, F., Comiskey, J.A. (eds.). Forest biodiversity in North, Central and South America, and the Caribbean. Paris, UNESCO, Man and the biosphere series 21: 681-700.

Steinhardt, U. 1978. Untersuchungen über den Wasser- und Nährstoffhaushalt eines andinen Wolkenwaldes in Venezuela. Dissertation, University Göttingen, Germany, pp. 182.

Tanner, E.V.J. 1977. Four montane rain forests of Jamaica: a quantitative characterization of the floristics, the soils and the foliar mineral levels, and a discussion of the interrelations. Journal of Ecology 65: 883- 918.

Tanner, E.V.J. 1985. Jamaican montane forests: nutrient capital and cost of growth. Journal of Ecology 73: 553-568.

Uhl, C., Jordan, C.F. 1984. Vegetation and nutrient dynamics during five years of succession following forest cutting and burning in the Rio Negro Region of Amazonia. Ecology 65: 1476-1490.

Valencia, R., Jørgensen, P.M. 1992. Composition and structure of a humid montane forest on the Pasochoa Volcano, Ecuador. Nordic Journal of Botany 12: 239-247.

Valencia, R. 1995. Composition and structure of an andean forest fragment in Eastern Ecuador. In: Churchill, S.P., Balslev, H., Forero, E., Luteyn, J.L. (eds.). Biodiversity and conservation of neotropical montane forests. New York Botanical Garden, Bronx, pp. 239-247.

Veillon, J.P. 1985. El crecimiento de algunos bosques naturales de Venezuela en relación con los parametros del medio ambiente. Revista Forestal Venezolana 29: 5-119.

Weaver, P.L., Murphy, P.G. 1990. Forest structure and productivity in Puerto Rico's Luquillo Mountains. Biotropica 22: 69-82.

Wilcke, W., Hess, T., Bengel, C., Homeier, E., Valarezo, E., Zech, W. 2005. Coarse woody debris in a montane forest in Ecuador: mass, $\mathrm{C}$ and nutrient stock, and turnover. Forest Ecology and Management 205: 139-147.

Young, K.R. 1993. Tropical timberlines - changes in forest structure and regeneration between 2 Peruvian timberline margins. Arctic Alpine Research 25: 167-174.

Young. K.R. 1998. Composition and structure of a timberline forest in North-Central Peru. In: Dallmeier, F., Comiskey, J.A. (eds.). Forest biodiversity in North, Central and South America, and the Caribbean. Paris, UNESCO, Man and the biosphere series 21: 595-613.

Young, K.R., Keating, P.L. 2001. Remnant forests of Volcan Cotacachi, northern Ecuador. Arctic, Antarctic and Alpine Research 33: 165-172. 


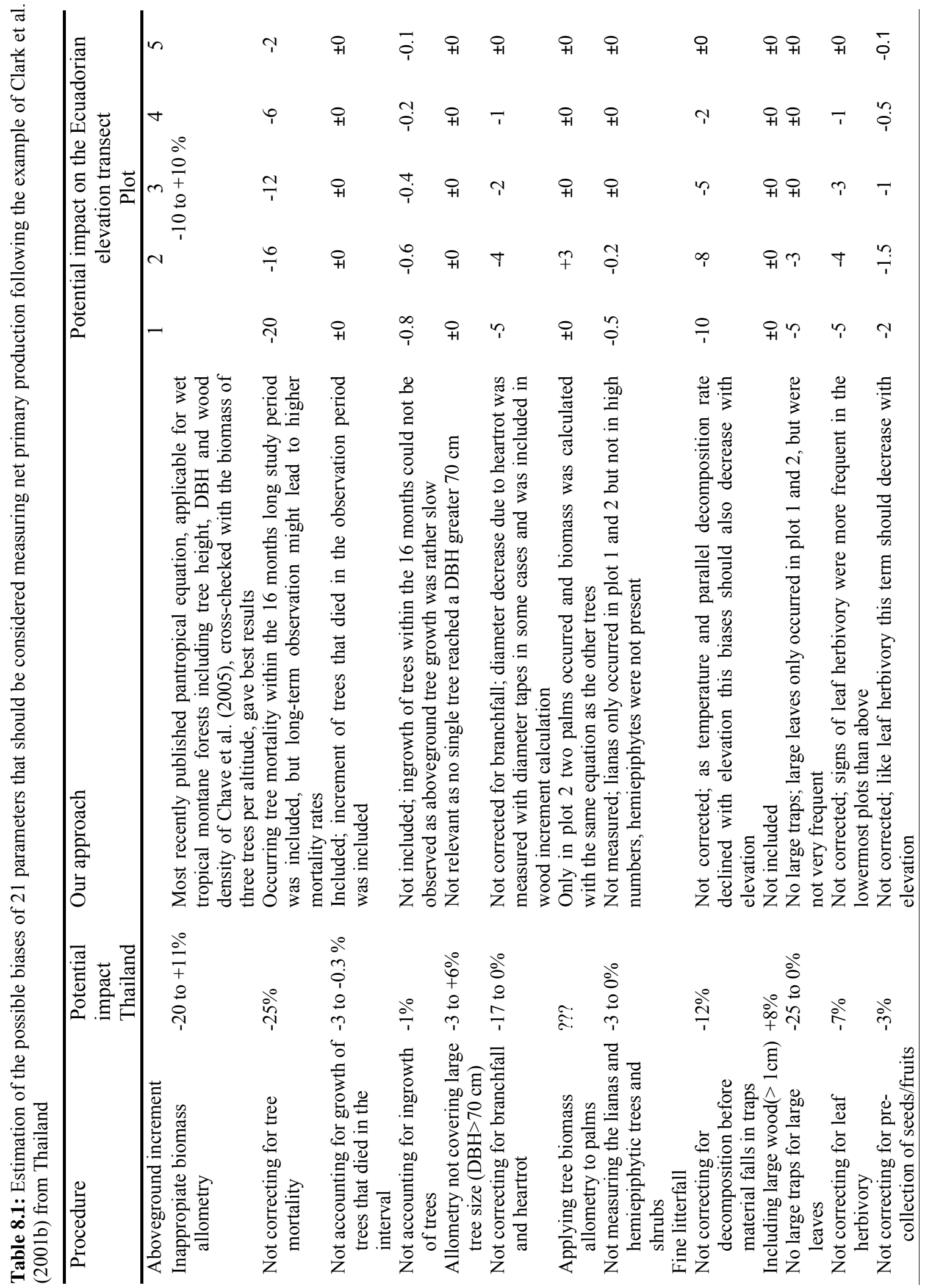




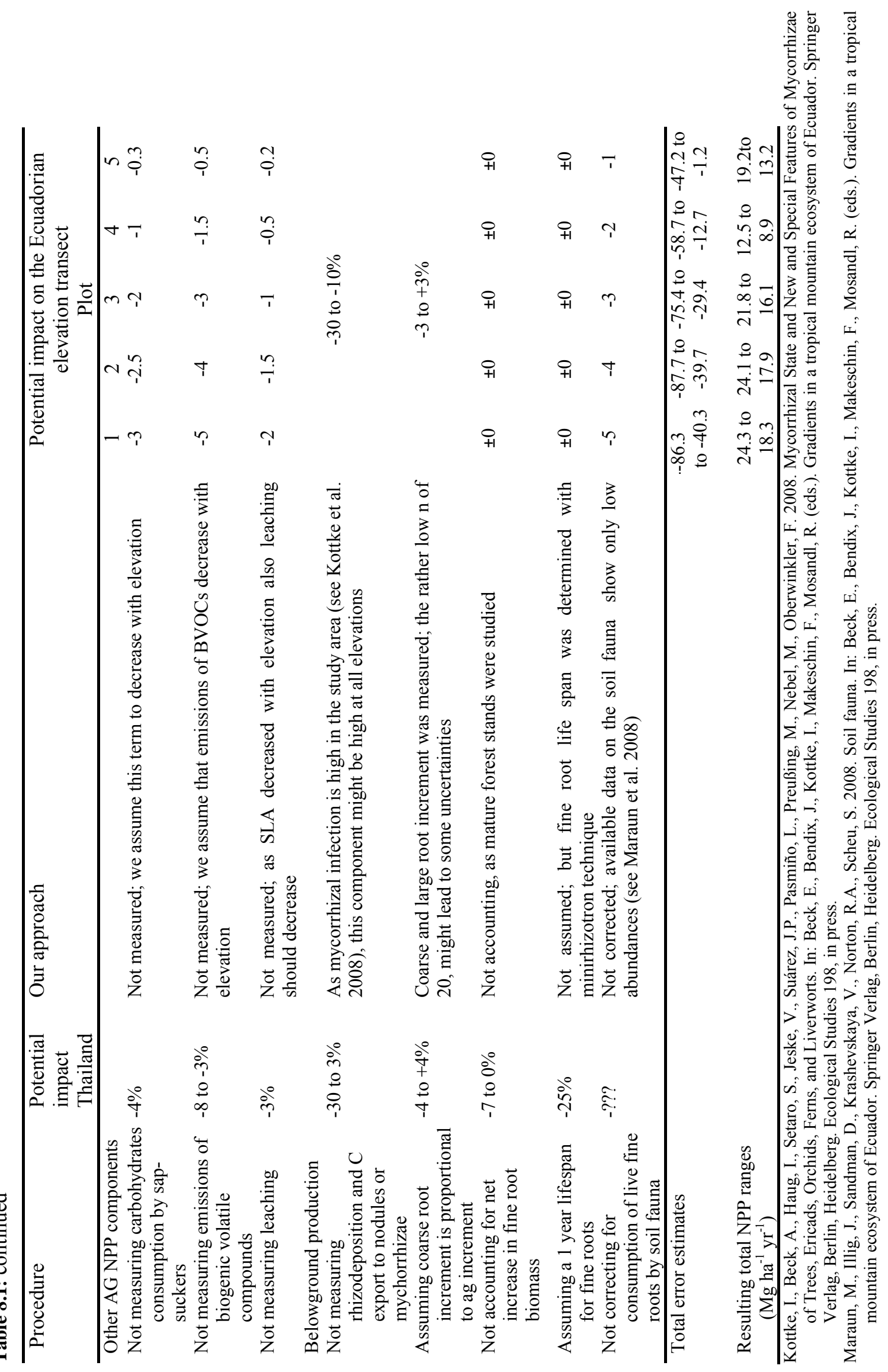






\section{A C K N O W L E D G E M E N T S}

The nearly five years of working on this $\mathrm{PhD}$-thesis have been a very intensive period of time. Within this time not only my knowledge and experience grew, but also the number of my family members did from three to five. The 16 months of fieldwork in Ecuador and living there 10 months together with my family, was an very interesting time I would not want to miss. I am very glad that I got the chance to fulfil the dream of working in a tropical rainforest. However, it would have never been possible without the help of many people.

First of all I would like to thank Prof. Christoph Leuschner and Dr. Dietrich Hertel for giving me the opportunity to do this research, for their great interest, useful discussions and their continuous support during the last five years. As I enjoyed the very nice working atmosphere at the Department of Plant Ecology during the last years, I am glad to be able to continue here, doing research in the tropics.

Special thanks to Marina for a very nice time together in Ecuador and here in Göttingen, and for your great help in uncountable cases. Many thanks to Heinz for the technical instructions and the support in finding problem solutions, to Mechthild, Jutta and Ute for sample preparation and chemical analysis. For the assistance, data exchange and useful discussions within the Department I would like to thank Chris, Malte, Bernhard, Jürgen, Dirk, Sophie and Alex. I am particularly grateful to Susanne Iost and Nathalie Soethe for the very intensive cooperation and ongoing friendship. Without all the additional data, it would have been impossible to interpret my own data in the wright way and to finish this thesis. Thanks to Friederike and Stella for proof reading.

Further I would like to thank all my colleagues within the Ecuador Research Unit 442: Living five months at the Estación Científica San Francisco and eleven months in Loja would not have been such a great time without you: Felix, Alfredo, Jörg, Melania, Nicki, Jana, Florian, Steffi and many more.

Special thanks to Paul Emck and Prof. Michael Richter for provision of metheorological data, Sven Günther for making a Vertex III Forestor device and stem wood corer available, Mathias Oesker for providing the equipment for hemispherical photography, and to Prof. Manfred Küppers for allocating a Licor LAI-2000 instrument.

Thanks to Rocio and Maria, for cooking at the Estación and for attending to my children, and to Roberth, Tati and Abraham for transportation.

Last but not least I would like to express special gratitude to my family: To Anette, for her encouragement to fulfil the dream of working in a tropical rainforest, her attendance to move together with Jakob and Merle to Ecuador, and her patience during the last five years. I am thankful to my children Jakob, Merle and Elsa for their acceptance of my work and for their unconditional love. I am grateful to Astrid \& Patrice, Judith \& Sigi, my dad, Friederike, Christian \& Fanny, and especially to Edith and Manfred for taking care of my children during the periods of my absence and for their endless help and support. 



\section{URRICULUM VITAE}

\section{Personal details}

$\begin{array}{ll}\text { Date of birth } & \text { 3. Dezember } 1974 \\ \text { Place of birth } & \text { Ried i. I., Austria } \\ \text { Nationality } & \text { Austrian }\end{array}$

\section{EDUCATION}

2003 - 2007 Phd-study at the Departement of Plant Ecology, Albrecht-von-Haller-Institute for Plant Sciences University of Göttingen, Germany

1994 - 2001 Study of Biology at the University of Salzburg, Austria, Degree obtained: Mag. rer. nat.

Thesis title: Geobotanischer Vergleich der alpinen Kalkschiefer-Vegetation der Skanden und der Alpen

1999 Seven months of study and fieldwork in Trondheim and Dovrefjell National Park, Norway

1985 - 1993 Bundesrealgymnasium Salzburg, Austria

High school graduation: Allgemeine Hochschulreife

\section{WORK EXPERIENCE}

2006-dato Scientific coordination of the "Sulawesi Throughfall Displacement Experiment" and scientific investigation on the fine root system of a montane rainforest in the 'Lore Lindu National Park' and a cacao agroforest system in its vicinity during induced drought periods in Central Sulawesi, Indonesia, within the DFG research cluster SFB 552 "Stability of Rainforest Margins - STORMA"

2005 Graduate assistant at the University of Göttingen, Germany

2003 - 2004 Field work in the tropical montane rainforest of the 'Podocarpus National Park' and 'Estación Científica San Francisco' in South Ecuador for the PhDstudy as member of the DFG Research Unit 402 "Functionality in a Tropical Montane Rainforest"

2000 - 2001 Graduate assistant at the University of Bayreuth, Germany

2000 - 2001 Graduate assistant at the Botanical Institute, University of Salzburg, Austria

1999 - 2000 Freelance biologist working on the "Botanical Informationssystem - BIS " at the University of Salzburg, Austria

1999 - 2000 Organization of the congress "Biotopkartierung in Bergregionen" at the University of Salzburg, Austria, as a freelance biologist 